$$
\begin{aligned}
& \text { UNIVERSIDADE DE SÃO PAULO } \\
& \text { INSTITUTO DE GEOCIÊNCIAS }
\end{aligned}
$$

\title{
A Geoconservação como subsídio à gestão territorial sustentável: o mapa geoturístico do litoral norte do estado de São Paulo
}

\section{KARLLA EMMANUELLE CUNHA ARRUDA}

Orientadora: Profa ${ }^{\text {. Dra }}$. Maria da Glória Motta Garcia

Tese de Doutorado

Tese número 573

COMISSÃO JULGADORA

Presidente: Drâ. Maria da Glória Motta Garcia

Dra . Christine Laure Marie Bourotte

Drª . Kátia Leite Mansur

Dra ${ }^{\mathrm{a}}$. Jasmine Cardozo Moreira

Drª Simone Scifoni 
KARLLA EMMANUELLE CUNHA ARRUDA

A Geoconservação como subsídio à gestão territorial sustentável: o mapa geoturístico do litoral norte do estado de São Paulo

\section{Versão Original}

Tese apresentada ao Instituto de Geociências da Universidade de São Paulo para obtenção do título de Doutora em Ciências.

Área de Concentração: Mineralogia

Experimental e Aplicada

Orientadora:

Profa. Dra. Maria da Glória Motta Garcia Coorientadores:

Profa. Dra. Eliane Aparecida Del Lama

Prof. Dr. Guillermo Melendez Hévia

São Paulo

2017 
Autorizo a reprodução e divulgação total ou parcial deste trabalho, por qualquer meio convencional ou eletrônico, para fins de estudo e pesquisa, desde que citada a fonte.

Ficha catalográfica preparada pelo Serviço de Biblioteca e Documentação do Instituto de Geociências da Universidade de São Paulo

Arruda, Karlla Emmanuelle Cunha

A Geoconservação como subsídio à gestão territorial sustentável: o mapa geoturístico do litoral norte do estado de São Paulo / Karlla Emmanuelle Cunha Arruda. - São Paulo, 2017. 190 p. + anexos

Tese (Doutorado) : IGc/USP

Orient.: Garcia, Maria da Glória Motta

Coorient.: Lama, Eliane Aparecida Del

1. Geoconservação 2. Geodiversidade 3 . Geoturismo 4. Patrimônio Construído 5. Patrimônio Geológico I. Título 
Nome: ARRUDA, Karlla Emmanuelle Cunha

Título: A Geoconservação como subsídio à gestão territorial sustentável: o mapa geoturístico do litoral norte do estado de São Paulo

Tese apresentada ao Instituto de Geociências da Universidade de São Paulo para obtenção do título de Doutora em Ciências.

Aprovado em:

\section{Banca Examinadora}

Profa. Dra. Maria da Glória Motta Garcia

Instituição: Universidade de São Paulo

Julgamento:

Profa. Dra. Christine Laure Marie Bourotte

Instituição: Universidade de São Paulo

Julgamento:

Profa. Dra. Jasmine Cardozo Moreira

Instituição: Universidade Estadual de Ponta Grossa

Julgamento:

Profa. Dra. Kátia Leite Mansur

Instituição: Universidade Federal do Rio de Janeiro

Julgamento:

Profa. Dra. Simone Scifoni

Instituição: Universidade de São Paulo

Julgamento: 
Dedico esta tese a todas as mulheres que me antecederam no ramo das ciências e que com muita luta abriram o caminho para que eu chegasse até aqui. 


\section{AGRADECIMENTOS}

À minha orientadora Profa. Dra. Maria da Glória Motta Garcia, e à minha coorientadora Profa. Dra. Eliane Aparecida Del Lama, por absolutamente tudo.

Ao meu coorientador Profo Dr. Guillermo Melendez Hévia.

A Anchel Belmonte, pelo auxílio durante as visitas ao Geoparque de Sobrarbe.

À Mariana Vilas Boas pelo companheirismo e amizade durante as visitas ao Geoparque Naturtejo.

A todos os gestores e monitores dos Núcleos de São Sebastião, Caraguatatuba e Ubatuba do Parque Estadual da Serra do Mar, e do Parque Estadual de Ilhabela.

Ao Conselho Nacional de Desenvolvimento Científico e Tecnológico - CNPq.

Ao Programa Ciências Sem Fronteiras.

À Universidade de São Paulo.

À Universidad de Zaragoza.

A Carlos Mazzoca pelo auxílio técnico.

As colegas e amigas de trabalho Vanessa Mucivuna e Fernanda Reverte. 


\section{RESUMO}

O litoral norte de São Paulo é caracterizado por registros de uma história geológica relacionada à amalgamação e fragmentação do Supercontinente Gondwana Ocidental, sua evolução está relacionada à formação da Serra do Mar e a abertura do Oceano Atlântico Sul. Trata-se de uma região potencialmente atraente para o desenvolvimento de atividades geoturísticas e de divulgação científica, sendo as formas da paisagem, resultantes de fenômenos geológicos, importantes atrativos turísticos concentrados principalmente nas praias. A região possui uma rica herança cultural advinda das comunidades tradicionais. Com base nesses aspectos e visando a relevância científica e cultural dessa região verifica-se a necessidade de realizar um estudo de forma a descrever e identificar aspectos relevantes da geodiversidade e da cultura, e elaborar um mapa geoturístico integrado para o litoral norte do estado de São Paulo. Este trabalho teve como objetivo inventariar e avaliar quantitativamente o patrimônio geológico de Caraguatatuba e os sítios da geodiversidade do litoral norte de São Paulo; inventariar os sítios do patrimônio construído no litoral norte de São Paulo; e integrar todos os sítios inventariados para elaborar o mapa geoturístico do litoral norte de São Paulo, propondo-o como uma estratégia de geonconservação para a região. Este estudo utilizou métodos préexistentes e desenvolveu métodos de seleção de sítios da geodiversidade e do patrimônio construído para alcançar o resultado obtido. O mapa geoturístico resultante neste trabalho consiste em um produto que fundamenta a importância do geoturismo para a conservação da geodiversidade. O presente trabalho oferece uma alternativa para a descentralização do turismo na região, com uma abordagem geológica levando em conta o turismo sustentável e destaca a importância da percepção e compreensão da paisagem geológica e da geoconservação como parte importante da conservação do patrimônio natural.

Palavras-chave: Geoconservação. Geodiversidade. Geoturismo. Patrimônio Construído. Patrimônio Geológico. 


\begin{abstract}
The northern coast of the state of São Paulo is characterized by records of a geological history related to the amalgamation and fragmentation of the Western Gondwana Supercontinent. Its evolution is related to the formation of Serra do Mar and the opening of the South Atlantic Ocean. As a potentially attractive region for the development of geotourism activities and popularization of science, its landscape forms, resulting from geological phenomena, are important tourist attractions concentrated mainly on the beaches. In addition, the region has a rich cultural heritage of the local traditional communities. Based on these aspects and aiming at the scientific and cultural relevance of this region, it is necessary to carry out a study in order to describe and identify relevant aspects of geodiversity and culture, and to elaborate an integrated geotourism map of the northern coast of São Paulo. The purpose of this work is the inventory and quantitative evaluation of the geological heritage of Caraguatatuba town and of the geodiversity sites of the northern coast of São Paulo; inventory of the built heritage sites on the northern coast of São Paulo; integration of all the inventoried sites for the purpose of elaborating the geotouristic map of the northern coast of the state of São Paulo, proposing it as a strategy of the region's geonconservation. This study used pre-existing methods as well as developed the new ones, those of the geodiversity and built heritage sites selection in order to achieve the result obtained. The geotourism map resulting from this research, is a product that substantiates the importance of geotourism for the conservation of geodiversity. The present work offers an alternative for the decentralization of tourism in the region, with a geological approach taking into account the sustainable tourism, and emphasizes the importance of the perception and understanding of the geological landscape and the geoconservation as a part of the conservation of the natural heritage.
\end{abstract}

Keywords: Geoconservation. Geodiversity. Geotourism. Built Heritage. Geological Heritage. 


\section{LISTA DE MAPAS}

Mapa 1 - Mapa geológico do litoral norte de São Paulo com a localização dos pontos inventariados (Adaptado de Perrotta et al. 2005)...

Mapa 2 - Mapa Geoturístico de São Sebastião..................................................46

Mapa 3 - Mapa Geoturístico de Ilhabela............................................................ 47

Mapa 4 - Mapa Geoturístico de Caraguatatuba..................................................48

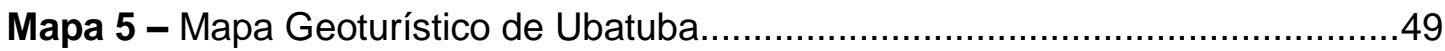




\section{LISTA DE FIGURAS}

Figura 1 - Localização do litoral norte do estado de São Paulo.

Figura 2 - Unidades de Conservação no litoral norte de São Paulo. Fonte: Adaptado SMA-SP, 2005. 20 Figura 3 - Mapa demográfico da população indígena no litoral norte de São Paulo. Fonte: IBGE, 2010.

Figura 4 - Esquema diagrama sobre o conteúdo científico e o conteúdo turístico. Fonte: Melendez et al. (2011)

Figura 5 - Exemplos de geração de empregos e geoprodutos gerados através do geoturismo. a Georestaurante Petiscos e Granitos, no Geoparque Naturtejo em Portugal, localizado entre blocos e afloramentes de granitos (Foto: Thais Guimarães); b - estudante de geologia realizando estágio como guía geoturística no Geoparque da Costa Basca, País Basco; c - loja de souvenirs na Islândia com diversas peças da geodiversidade à venda, como basaltos e poeira vulcânica; $d$ - confeiteira de uma comunidade de mulheres em Lesbos, Grécia, apresentando seus produtos para os visitantes do Geoparque da Floresta Petrificada em Lesbos.

Figura 6 - Painéis de interpretação da geodiversidade. a - Geoparque de Sobrarbe, Espanha; b Geoparque da Floresta Petrificada em Lesbos, Grécia; c - Colônia Witmarsum, Paraná; d - Parque do Varvito, São Paulo.

Figura 7 - Centros de interpretação da geodiversidade. a - Geoparque de Sobrarbe, Espanha; b Geoparque da Costa Basca, País Basco; c-Geoparque de Lesbos, Grécia; d - Geyser Center, Islândia.

Figura 8 - Exemplos de ações de geoconservação no litoral norte de São Paulo. a - painel interpretativo sobre a geodiversidade local, localizado na Sede do PESM - Núcleo Caraguatatuba; b painel interpretativo síntese do roteiro geoturístico do litoral norte de São Paulo, em Caraguatatuba; c - roteiro geointerpretativo de trilhas, Trilha da Praia Brava, São Sebastião; d - curso de geociências para monitores ambientais no PESM; e - aula de campo para os monitores do PESM, em São

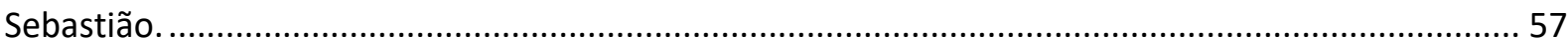

Figura 9 - Fluxograma das etapas para a elaboração do mapa geoturístico. 59

Figura 10 - Aspectos culturais no município de São Sebastião a - Aldeia Indígena Rio Silveira (Fonte: http:www.bertioga.sp.gov.br/turismo); b - Mapa virtual da rota Passos dos Jesuítas (Fonte: http:www.passosdosjesuitas.com.br); c - Gastronomia caiçara, peixe azul-marinho; d - Museu de Arte Sacra; e - parede original preservada dentro da Secretaria de Turismo; $f$ - parede original preservada em comércio local.

Figura 11 - Patrimônio Cultural em Ilhabela. a - Antigo Mercado de Escravos registrado na pintura do artista Debret, em 1827; b - antigo pelourinho localizado na Praça Coronel Júlio de Moura Negrão. 62 Figura 12 - Geoforma Pedra da Freira; a - aspecto atual da Pedra da Freira, na Praia do Garcez; b ilustração representando a lenda associada à geoforma, que diz que uma freira teria morrido afogada no local e, em sua homenagem, Deus petrificou sua imagem rezando ajoelhada para que a freira seja sempre lembrada pelos moradores locais. O manto da Freira é formado pelas fraturas que seguem a foliação da rocha.

Figura 13 - Morro do Santo Antônio em Caraguatatuba. a - Comemoração do mês de Santo Antônio no Morro do Santo Antonio. Fotos: Gianni D’ Angelo; b - Prática de voo livre no Morro do Santo Antônio, Caraguatatuba (Foto: Gustavo Grunewald); c - painel interpretativo (Foto: Maria da Glória); d - Vista à partir do mirante do Morro do Santo Antônio. 
Figura 14 - Arquivo Público de Caraguatatuba. a - biblioteca do arquivo público de Caraguatatuba; b - foto antiga do Morro do Santo Antônio disponibilizada pelo Arquivo Público (sem data)

Figura 15 - Núcleo de Cerâmica Artesanal Terramar em Caraguatatuba. a - Artesão Ben-Hur manipulando a argila com técnicas indígenas para criar a peça de cerâmica; b - Entrada do Ateliê Terramar com exposição de peças confeccionadas no local à venda.

Figura 16 - Estrada da Petrobras. a - prática de ciclismo de aventura na Estrada da Petrobras, (Fonte: https://www.pedal.com.br/); b - Geossítio Milonitos e Cataclasitos da Estrada da Petrobras; c afloramentos de gnaisse milonítico na estrada.

Figura 17 - Comunidades tradicionais em Ubatuba. a - Casa de Farinha, Quilombo da Fazenda; b artesanato local, Quilombo da Fazenda; c - Aldeia Indígena Boa Vista; d - trilha que leva à Aldeia Indígena Boa Vista, acompanhando o curso do Rio Prumirim com disposição de alguns blocos de charnockito; e - horta para educação ambiental dentro da Aldeia Indígena Boa Vista; $f$ - artesanato confeccionado pelas mulheres da aldeia. 68

Figura 18 - Atrações turísticas em Ubatuba. a - Antiga cadeia na llha Anchieta (Fonte: https://www.litoralbrasileiro.com.br/sp/ubatuba/ilha-anchieta.htm); b - Projeto Tamar; c Artesanato local; d - Marco geográfico do Trópico de Capricórnio.

Figura 19 - Exemplos de serviços e produtos que podem ser incrementados através do geoturismo no litoral norte de São Paulo. a - Restaurante Pedra do Sino, localizado no Geossítio Pedra do Sino em Ilhabela, dispõe de martelos para os clientes ouvirem os fonolitos do geossítio; b - restautante especializado em gastronomia caiçara localizado sobre um afloramento de Charnockito no Geossítio Charnockito Ubatuba, em Ubatuba; c - morador local e monitor ambiental do PESM explicando a sedimentação do mangue durante a Trilha Fluvial no Rio Fazenda; d - artesanato indígena confeccionado com rochas locais

Figura 20 - Sede do PESM - Núcleo São Sebastião. a - Estrutura externa (Fonte: http://www.parqueestadualserradomar.sp.gov.br/pesm/nucleos/sao-sebastiao/); b - Estrutura interna com espaços para apresentações e recursos multimídia

Figura 21 - Sede do Parque Estadual de Ilhabela; a - sede localizada no antigo fórum e cadeia da cidade; b - exposição interna sobre a história arqueológica na ilha; c - exposição sobre a natureza na ilha.

Figura 22 - Museu de Arte e Cultura de Caraguatatuba - MACC. a - entrada do museu; b - exposições na área interna do museu.

Figura 23 - Sede do PESM - Núcleo Picinguaba; a - casa da Sede; b - exposição de uma casa típica caiçara no local. 


\section{LISTA DE TABELAS}

Tabela 1 - Áreas protegidas no litoral norte de São Paulo.

Tabela 2 - Residências secundárias por município no litoral norte de São Paulo.

Tabela 3 - Dados populacionais e econômicos dos municípios do litoral norte de São Paulo.

Tabela 4 - Dados econômicos e sociais dos municípios do litoral norte de São Paulo. ....... 23

Tabela 5 - Levantamento de dados de sítios potenciais. ................................................25

Tabela 6 - Critérios e parâmetros para a quantificação do Valor Científico dos geossítios. . 26

Tabela 7 - Critérios e parâmetros de quantificação do Risco de Degradação.

Tabela 8 - Critérios e parâmetros para a quantificação do Potencial de uso educacional e turístico dos geossítios.

Tabela 9 - Pesos dos critérios de avaliação do potencial de uso educativo e turístico. 30

Tabela 10 - Valores de potencial de uso educacional e turístico dos geossítios do litoral norte de São Paulo. Cálculo obtido pelo GEOSSIT (ROCHA et al., 2016).

Tabela 11 - Valores de potencial de uso educacional e turístico dos sítios da geodiversidade do litoral norte de São Paulo. Cálculo obtido pelo GEOSSIT (ROCHA et al., 2016)..... 38

Tabela 12 - Sítios de patrimônio construído do litoral norte de São Paulo (ARRUDA et al., 2017).

Tabela 13 - Tabela preliminar de possíveis atores sociais na gestão do geoturismo no litoral norte de São Paulo. 


\section{SUMÁRIO}

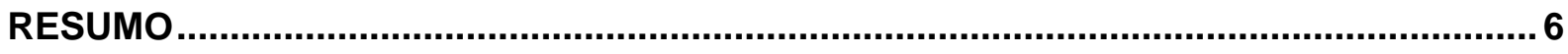

1 INTRODUÇÃO

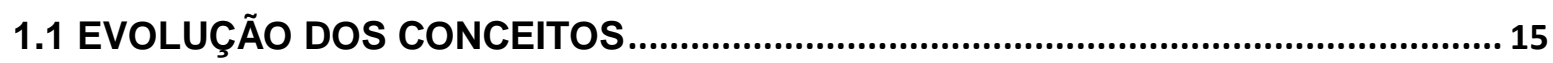

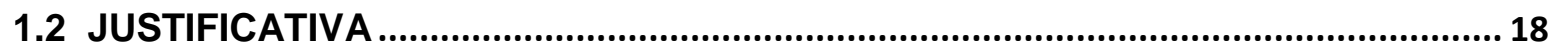

1.3 OBJETIVOS

1.4 CARACTERIZAÇÃO DA ÁREA DE ESTUDO ………............................................. 19

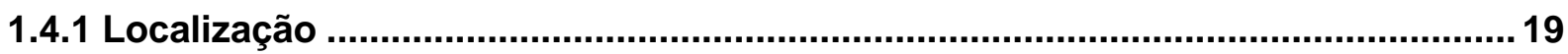

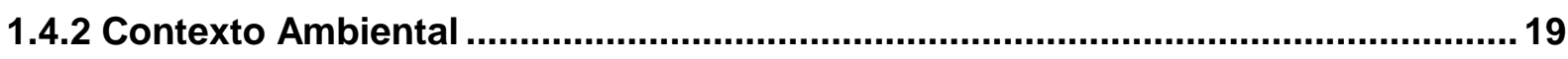

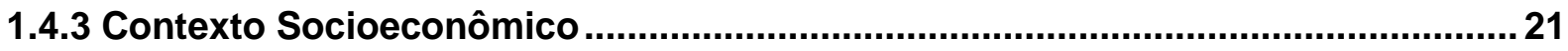

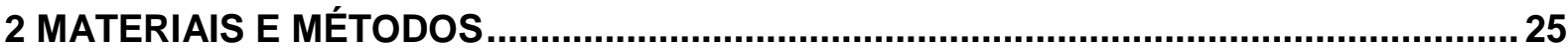

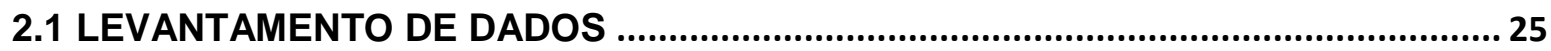

2.2 SELEÇÃO E AVALIAÇÃO QUANTITATIVA DE GEOSSÍTIOS EM

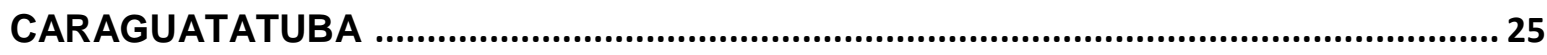

2.3. AVALIAÇÃO QUANTITATIVA DOS GEOSSÍTIOS EM OUTROS MUNICÍPIOS........ 30

2.4 SELEÇÃO E AVALIAÇÃO QUANTITATIVA DOS SÍTIOS DA GEODIVERSIDADE.. 31

2.5 SELEÇÃO DO PATRIMÔNIO CONSTRUÍDO.

3 INVENTÁRIO E QUANTIFICAÇÃO DO PATRIMÔNIO GEOLÓGICO DO MUNICÍPIO DE

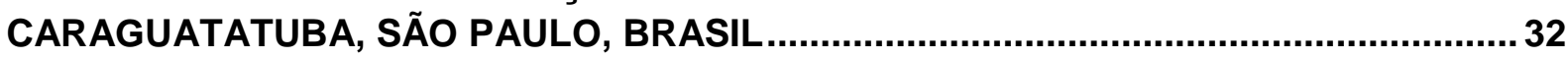

4 MÉTODO DE SELEÇÃO E PROPOSTAS DE USO DOS SíTIOS DA GEODIVERSIDADE: EXEMPLO DO LITORAL NORTE DO ESTADO DE SÃO PAULO, BRASIL ........................33

5 INVENTÁRIO GEOLÓGICO DO PATRIMÔNIO CONSTRUÍDO NO LITORAL NORTE DO

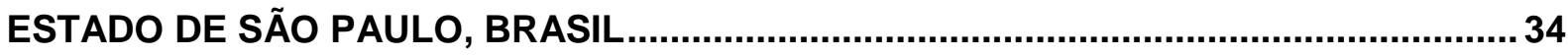

6 MAPA GEOTURÍSTICO DO LITORAL NORTE DO ESTADO DE SÃO PAULO................ 35

6.1 SELEÇÃO DOS PONTOS PARA COMPOSIÇÃO DO MAPA GEOTURÍSTICO ......... 35

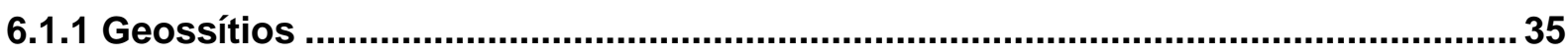

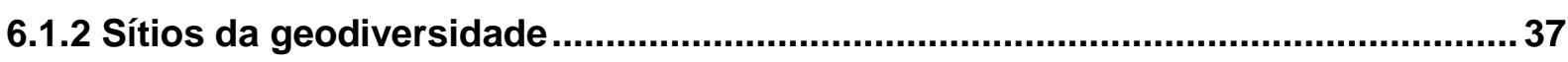

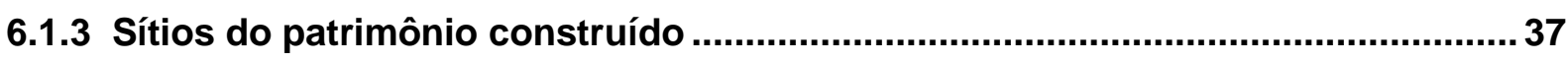

6.1.4 Outros pontos do mapa geoturístico............................................................ 39

6.2 MAPA GEOTURÍSTICO E A GEODIVERSIDADE DO LITORAL NORTE DE SÃO

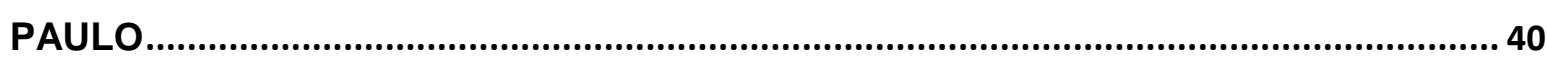

6.3 MAPA GEOTURÍSTICO INTEGRADO

6.3.1 Mapa Geoturístico do Município de São Sebastião .................................................. 42

6.3.2 Mapa Geoturístico do Município de Ilhabela........................................................ 43

6.3.3 Mapa Geoturístico do Município de Caraguatatuba ................................................ 44

6.3.4 Mapa Geoturístico do Município de Ubatuba........................................................... 44 
7 DISCUSSÃO E CONCLUSÕES 50

7.1 INTERPRETAÇÃO DA GEODIVERSIDADE ATRAVÉS DO GEOTURISMO 51

7.2 SERVIÇOS E BENEFÍCIOS SOCIOECONÔMICOS ASSOCIADOS AO GEOTURISMO

7.3 ESTRATÉGIAS DE GEOCONSERVAÇÃO …………......................................... 54

7.4 AÇÕES DE GEOCONSERVAÇÃO NO LITORAL NORTE DE SÃO PAULO..............56

7.5 ELABORAÇÃO DO MAPA GEOTURÍSTICO ……….............................................57

7.6 POTENCIAL GEOTURÍSTICO DOS MUNICÍPIOS …...............................................59

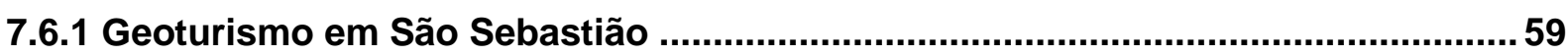

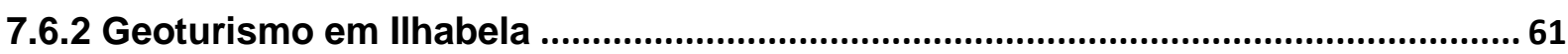

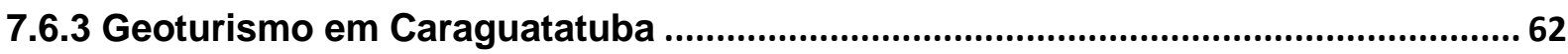

7.6.4 Geoturismo em Ubatuba ............................................................................................... 66

7.7 PROPOSTAS DE ESTRATÉGIAS DE GEOCONSERVAÇÃO PARA O LITORAL

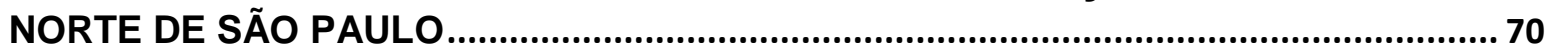

7.7.1 Articulação dos possíveis atores para a gestão do geoturismo no litoral norte de

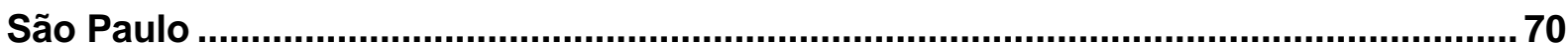

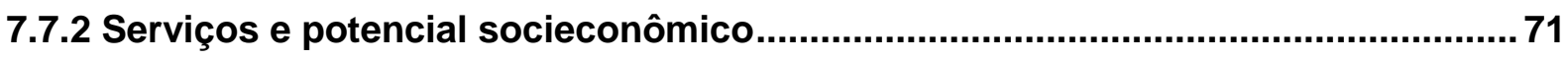

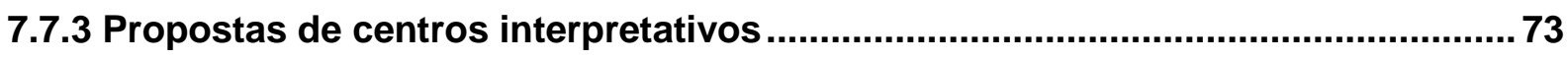

8 CONSIDERAÇÕES FINAIS...................................................................................... 77

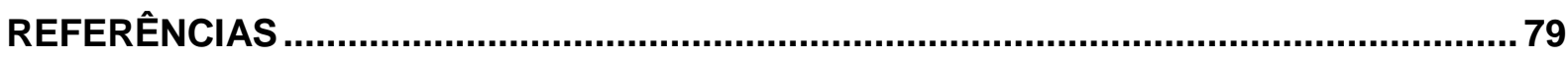

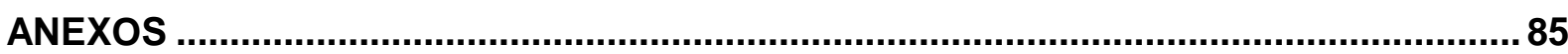

ANEXO A - INVENTÁRIO E QUANTIFICAÇÃO DO PATRIMÔNIO GEOLÓGICO DO MUNICÍPIO DE CARAGUATATUBA, SÃO PAULO, BRASIL........................................8

ANEXO B - MÉTODO DE SELEÇÃO E PROPOSTAS DE USO DOS SÍTIOS DA GEODIVERSIDADE: EXEMPLO DO LITORAL NORTE DO ESTADO DE SÃO PAULO, BRASIL

ANEXO C - INVENTÁRIO GEOLÓGICO DO PATRIMÔNIO CONSTRUÍDO NO LITORAL NORTE DO ESTADO DE SÃO PAULO, BRASIL 


\section{INTRODUÇÃO}

A humanidade sempre esteve diretamente ligada aos elementos geológicos, sendo o patrimônio cultural constantemente recriado pelas comunidades e grupos em função do ambiente em que vivem, proporcionando-Ihes um sentimento de identidade e continuidade. No litoral norte do estado de São Paulo, a história da ocupação humana remete a diversos aspectos geológicos. Exemplos são a arqueologia, com a utilização de materiais extraídos da geodiversidade para confecção de ferramentas (BENDAZOLLI, 2011); a geomorfologia, com a presença da Serra do Mar impondo barreiras geomorfológicas para os bandeirantes durante o período colonial; e a economia, com atividades de mineração, como a extração do charnockito em Ubatuba.

Verifica-se, portanto, que a história antropológica está diretamente relacionada à base geológica da superfície do planeta, algumas vezes auxiliando positivamente no desenvolvimento da humanidade a partir de seus produtos e topografia, outras vezes agindo negativamente, como catástrofes naturais, como os escorregamentos.

O litoral norte do estado de São Paulo é constituído por uma geodiversidade que revela uma parte importante da história geológica da Terra, registrando em suas rochas as fases de amalgamação e fragmentação do Supercontinente Gondwana Ocidental. Trata-se de uma área rica em beleza cênica e atraente para atividades de sol e praia, ocasionando um turismo de massa sem o direcionamento necessário para os valores físicos e culturais existentes na região, e destrutivo para o ambiente, pois banaliza o patrimônio natural e marginaliza as comunidades tradicionais locais. $\mathrm{Na}$ região, a especulação imobiliária domina a linha de costa, em alguns casos privando o acesso a importantes elementos da geodiversidade, havendo destruição de afloramentos por conta do crescimento urbano. Com base nesse contexto e visando o potencial geológico da região, verifica-se a necessidade de realizar um estudo de forma a desenvolver um mapa geoturístico (apresentado nesta tese em formato acadêmico) e propor medidas de geoconservação na região.

Esta tese está organizada sob a forma de texto redigido e artigos publicados e/ou submetidos em revistas indexadas - estes últimos disponíveis integralmente nos anexos. O capítulo introdutório apresenta o tema da pesquisa e contém uma síntese da evolução dos conceitos relacionados à geoconservação, a justificativa e os objetivos do trabalho, além da descrição dos contextos ambientais e 
socioeconomicos da área de estudo. No segundo capítulo são apresentados os materiais e métodos utilizados para inventariar e avaliar o patrimônio natural abiótico da região, que consistem no inventário e avaliação quantitativa do patrimônio geológico do município de Caraguatatuba, avaliação quantitativa do potencial de uso educativo e turístico dos geossítios do litoral norte de São Paulo, seleção e análise quantitativa dos sítios da geodiversidade do litoral norte de São Paulo e o inventário do patrimônio construído. Os capítulos três, quatro e cinco correspondem aos artigos resultantes desta tese, que descrevem i) o patrimônio geológico do município de Caraguatatuba, ii) os sítios da geodiversidade do litoral norte de São Paulo e iii) o patrimônio construído do litoral norte de São Paulo, respectivamente. O sexto capítulo corresponde à descrição do processo de desenvolvimento e à apresentação do mapa geoturístico, composto a partir dos elementos obtidos nos estudos precedentes. No capítulo sete são apresentadas a integração entre os dados obtidos e as propostas associadas ao mapa geoturístico em termos de geoconservação e gestão territorial baseada no uso turístico.

\subsection{EVOLUÇÃO DOS CONCEITOS}

O levantamento do patrimônio geológico na região baseou-se na emersão dos conceitos de geodiversidade, patrimônio geológico, geoconservação e geoturismo na década de 1990 e na importância desta área de estudo para a conservação da história geológica da Terra.

O termo "geodiversidade" foi citado pela primeira vez em 1991 em uma conferência internacional. Contudo, foi na Conferência de Malvern sobre Conservação Geológica e Paisagística, ocorrida em 1993, no Reino Unido, que o termo passou a ser conhecido (GRAY, 2004). Desde então, o conceito de geodiversidade foi redefinido por diversos autores (DIXON, 1996; STANLEY, 2001; NIETO, 2001; KOZLOWSKI, 2004; GRAY, 2004; BRILHA, 2005; SERRANO \& RUIZFLANO, 2007; BUREK \& PROSSER, 2008; GRAY, 2013) até o presente. Neste trabalho foi utilizada a definição de Gray (2013), que define a geodiversidade como "a variedade natural (diversidade) de elementos geológicos (rochas, minerais, fósseis), geomorfológicos (relevo, topografia, processos físicos), hidrológicos e solos, incluindo as associações, estruturas, sistemas e contribuições à paisagem".

Dentro da geodiversidade existem locais que apresentam características geológicas de extrema importância e que merecem ser conservados. Estes locais, 
ao longo das últimas décadas, receberam diversas denominações, tais como "ponto de interesse geológico", definido por Duque et al. (1978) como "áreas que mostram uma ou várias características de importância dentro da história geológica de uma região natural". O termo "lugar de interesse geológico", definido em Arana et al. (1992), acrescentou que tais lugares também tratam de recursos renováveis de índole cultural que constituem o patrimônio geológico dos habitantes atuais e das gerações futuras. Em contrapartida a este último conceito surge o termo "domínios de interesse geológico" (LAGO et al., 2001), abrangendo zonas mais amplas e multidisciplinares.

O termo "geossítio" surgiu da palavra em inglês "geosite" e foi definido em 1991 como "manifestações geológicas ou geomorfológicas, terrenos ou paisagens que possuem uma informação indispensável para o entendimento da história geológica de um país, região ou continente, ou processos de caráter global" (WIMBLEDON et al., 1997). Em Brilha (2005) este termo foi definido como locais que apresentam um ou mais elementos da geodiversidade resultantes de processos naturais ou por meio de intervenção humana, sendo uma área bem delimitada geograficamente com algum valor representativo, no âmbito científico, pedagógico, cultural ou turístico, podendo apresentar um ou mais elementos de interesse, tais como estrutural, paleontológico, mineralógico, geomorfológico e estratigráfico. Segundo o autor, o conjunto de geossítios constitui o patrimônio geológico de uma dada região.

Brilha (2016) redefiniu o termo geossítio, passando a ser exclusivo para locais da geodiversidade que possuam valor científico relevante e estejam in situ. Os locais que apresentem importância científica, mas que se encontrem ex situ são denominados "elementos do patrimônio geológico". Por sua vez, os locais da geodiversidade que não possuam valor científico relevante, mas que sejam importantes no contexto didático, turístico e/ou cultural, são denominados "sítios da geodiversidade", quando in situ e "elementos da geodiversidade", quando ex situ. Esta proposta de classificação da diversidade natural torna possível diferenciar claramente sítios que têm alto interesse científico, mas limitado valor turístico e/ou educativo, daqueles que não possuem alta relevância científica mas que podem ser essenciais na gestão e uso da geodiversidade em várias escalas.

Com a intenção de popularizar e divulgar a geodiversidade de um local surge o geoturismo, uma atividade turística baseada nos princípios da geodiversidade, 
com oferta de informações sobre a geologia e os processos de formação da paisagem. A definição original de Geoturismo foi proposta por Hose (1995) para conceituar o tipo de turismo que tem como atrativos características geológicas, tais como formações rochosas e estruturas. Recentemente, novos aspectos foram incorporados à ideia inicial (HOSE, 2008; NEWSOME \& DOWLING, 2010; HOSE, 2012). Porém, o conceito de geoturismo mais utilizado é o descrito na Declaração de Arouca em 2011, que o define como o turismo que sustenta e incrementa a identidade de um território, considerando a sua geologia, ambiente, cultura, valores estéticos, patrimônio e o bem-estar dos seus residentes (DECLARAÇÃO DE AROUCA, 2011). Trata-se de um segmento do turismo com ênfase nos aspectos geológicos, caracterizado pelo contato com a natureza e pela busca de lazer com informação, trazendo consigo aspectos da cultura e da história local, gerando benefícios socioeconômicos para a comunidade.

Para Moreira (2010, 2011), o geoturismo abrange impactos positivos na natureza e na sociedade, como a conservação do patrimônio geológico, a geração de empregos diretos e indiretos, e a compreensão do ambiente através de uma educação geológica e ambiental para os visitantes, gerando um aumento na consciência da população local e turistas a respeito da geodiversidade local. Nascimento et al. (2007), abordam a importância de incluir a população local e sua cultura neste tipo de turismo, com o objetivo não apenas de gerar renda para os habitantes locais, mas também como uma forma de inseri-los no contexto socioambiental e econômico do território.

O geoturismo pode ser realizado dentro de uma área urbana, utilizando as rochas e minerais presentes no patrimônio construído, levando informações geológicas para a população, sem a necessidade de fazer com que o induvíduo se desloque para áreas naturais. No Brasil, algumas propostas de aplicação do geoturismo foram realizadas em: Stern et al. (2006); Piekarz \& Liccardo (2007); Liccardo et al. (2008); Letenski et al. (2009); Liccardo et al. (2012); Augusto \& Del Lama (2011); Piekarz (2011); Pinto (2015); Del Lama et al. (2015). A partir do inventário desse patrimônio são realizados estudos e ações para a conservação de suas pedras, tendo como objetivo salvaguardar tanto a obra como suas evidências históricas. 


\subsection{JUSTIFICATIVA}

A escolha do litoral norte do estado de São Paulo para a elaboração de um mapa geoturístico justifica-se pela emergente necessidade de apresentar à população formas de utilizar a geodiversidade de modo construtivo, seja através da educação, com a divulgação do patrimônio geológico e a importância de conserválo, ou através do turismo sustentável, levando lazer e contato direto com a geologia e seus produtos.

Estudos prévios realizados pelo Núcleo de Apoio à Pesquisa em Patrimônio Geológico e Geoturismo (GeoHereditas) do Instituto de Geociências da Universidade de São Paulo, levantaram o patrimônio geológico de parte do litoral norte de São Paulo (GARCIA, 2012; PROCHOROFF, 2014; SANTOS, 2014; REVERTE, 2014). Os resultados obtidos convergem para o elevado potencial da região para a aplicação do geoturismo, uma forma de integrar a geoconservação e a interpretação do patrimônio geológico, além de gerar benefícios socioeconômicos para a população local. Neste contexto, esta tese propõe uma integração dos dados adquiridos nesses estudos, somada ao inventário do patrimônio geológico de Caraguatatuba, dos sítios da geodiversidade e do patrimônio construído do litoral norte, compondo o mapa geoturístico e propostas de uso turístico na região.

\subsection{OBJETIVOS}

O objetivo geral desta tese é traçar estratégias de geoconservação que possam contribuir para a gestão territorial baseada no turismo nos municípios que compõem o litoral norte do estado de São Paulo.

Para alcançar esta meta geral, os seguintes objetivos específicos foram propostos:

a) Realizar o inventário e a avaliação quantitativa do patrimônio geológico do município de Caraguatatuba;

b) Inventariar e avaliar quantitativamente os sítios da geodiversidade do litoral norte de São Paulo;

c) Realizar o inventário do patrimônio construído do litoral norte de São Paulo;

d) Integrar os geossítios, sítios da geodiversidade e o patrimônio construído e cultural para a elaboração do mapa geoturístico do litoral norte de São Paulo;

e) Propor estratégias de geoconservação à partir do mapa geoturístico. 


\subsection{CARACTERIZAÇÃO DA ÁREA DE ESTUDO}

\subsubsection{Localização}

A área de estudo está inserida no litoral norte do estado de São Paulo e abrange os municípios de Ubatuba, Caraguatatuba, São Sebastião e Ilhabela, ocupando uma área de aproximadamente $2.000 \mathrm{~km}^{2}$ de extensão (Figura 1).

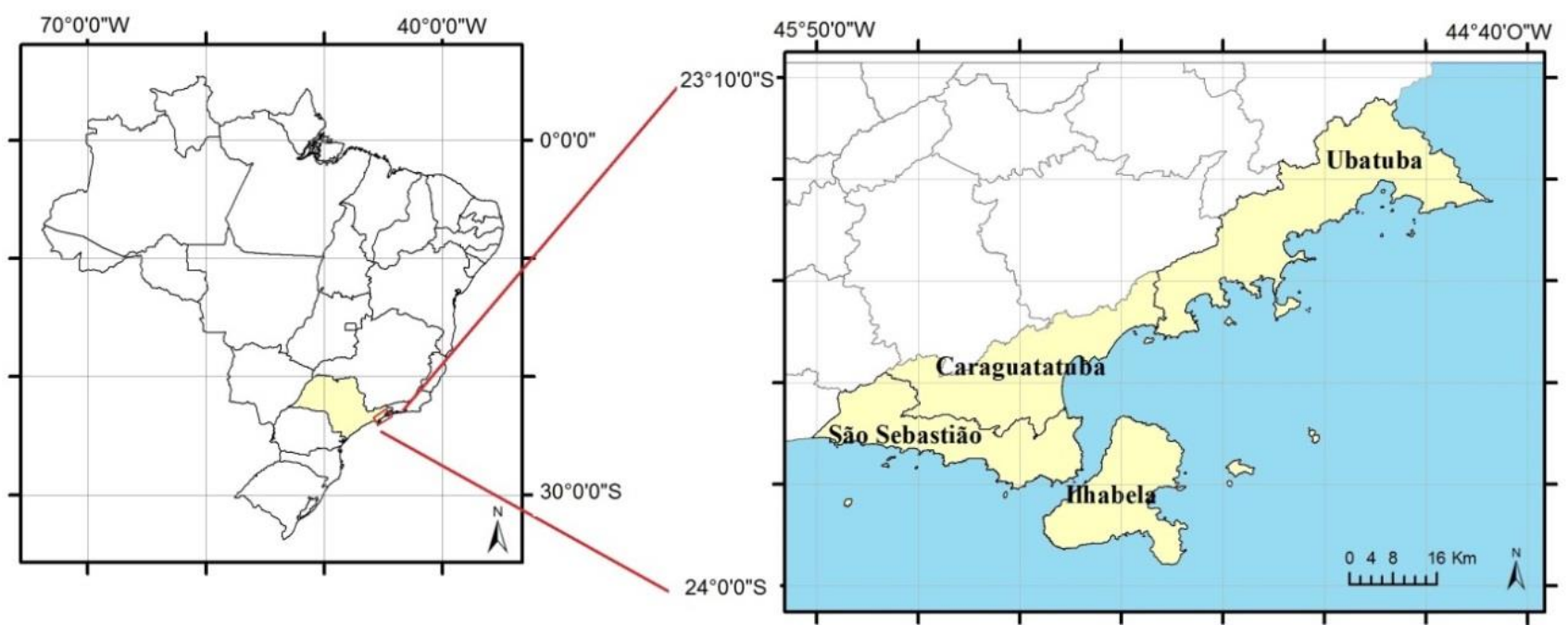

Figura 1 - Localização do litoral norte do estado de São Paulo.

\subsubsection{Contexto Ambiental}

A região abrange importantes Unidades de Conservação (UC's), que constituem espaços territoriais protegidos destinados à conservação e preservação do patrimônio natural. $\mathrm{Na}$ área de estudo, as UC's foram criadas com ênfase na preservação dos remanescentes florestais da Mata Atlântica localizada nas escarpas da Serra do Mar: Parque Estadual da Serra do Mar, Parque Estadual da llha Anchieta, Parque Estadual de Ilhabela e Área de Proteção Ambiental Marinha do Litoral Norte do Estado de São Paulo (Figura 2). Estes parques estaduais representam grande atrativo para o ecoturismo na região, com oferta de trilhas, cachoeiras, observação de fauna e flora, educação ambiental e contato direto com a natureza, sendo um importante fator turístico e educacional na região.

A área em foco neste trabalho, além de abranger importante patrimônio natural como a Serra do Mar e a Mata Atlântica, está inserida na interface continente/oceano, que apresenta particularidades ambientais e necessidades 
específicas de proteção ambiental. Esses aspectos levaram o poder público a criar instrumentos de proteção específicos para a região (Tabela 1), sendo o tombamento da Serra do Mar, em 1985, o passo mais importante para o reconhecimento da geodiversidade como parte do patrimônio natural.

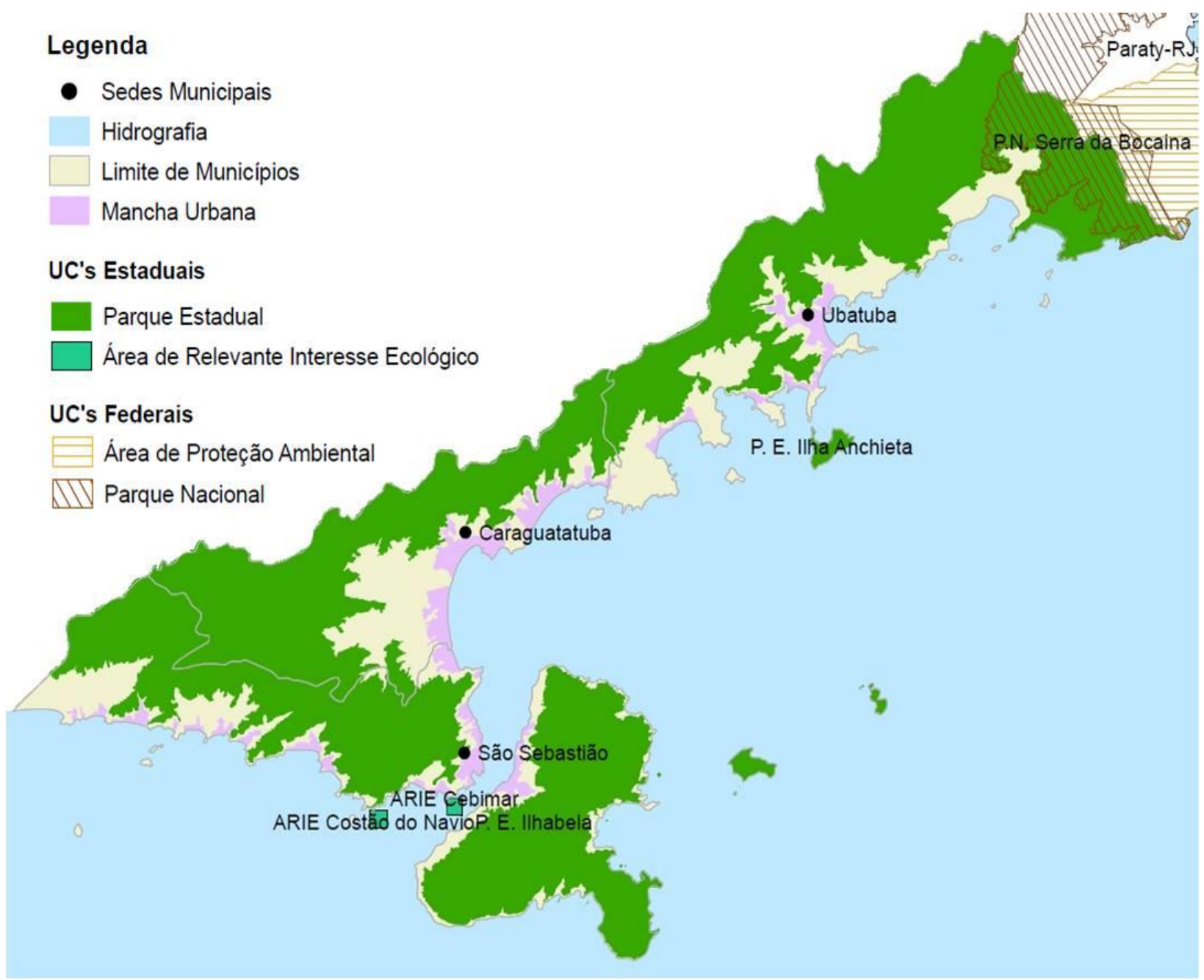

Figura 2 - Unidades de Conservação no litoral norte de São Paulo. Fonte: Adaptado SMASP, 2005. 
Tabela 1 - Áreas protegidas no litoral norte de São Paulo.

\begin{tabular}{|c|c|c|c|}
\hline Áreas Protegidas & Proteção Legal & Administração & $\begin{array}{c}\text { Municípios afetados na } \\
\text { área de estudo }\end{array}$ \\
\hline $\begin{array}{l}\text { Parque Nacional da Serra } \\
\text { da Bocaina }\end{array}$ & $\begin{array}{c}\text { Decretos Federais } 68.172 \\
\text { de } 4 / 2 / 1971 \text { e } 70.694 \mathrm{de} \\
8 / 6 / 1972\end{array}$ & $\begin{array}{l}\text { Instituto Brasileiro de } \\
\text { Meio Ambiente e dos } \\
\text { Recursos Renováveis - } \\
\text { IBAMA }\end{array}$ & Ubatuba \\
\hline $\begin{array}{l}\text { Parque Estadual de } \\
\text { Ilhabela }\end{array}$ & $\begin{array}{c}\text { Decreto Estadual 9.414, } \\
\text { de } 20 / 1 / 1977 \\
\end{array}$ & Instituto Florestal - IF & Ilhabela \\
\hline $\begin{array}{c}\text { Parque Estadual da llha } \\
\text { Anchieta } \\
\end{array}$ & $\begin{array}{c}\text { Decreto } 9.629, \text { de } \\
29 / 3 / 1977 \\
\end{array}$ & Instituto Florestal - IF & Ubatuba \\
\hline $\begin{array}{l}\text { Parque Estadual da Serra } \\
\text { do Mar }\end{array}$ & $\begin{array}{c}\text { Decretos Estaduais } \\
\text { 10.251, de } 30 / 8 / 1977 \text {, e } \\
13.313 \text {, de } 6 / 3 / 1979\end{array}$ & Instituto Florestal - IF & $\begin{array}{c}\text { Ubatuba, Caraguatatuba, } \\
\text { São Sebastião }\end{array}$ \\
\hline $\begin{array}{l}\text { Tombamento do Núcleo } \\
\text { Caiçara de Picinguaba }\end{array}$ & $\begin{array}{c}\text { Resolução Estadual } 7 \text { de } \\
1 / 3 / 1983\end{array}$ & $\begin{array}{l}\text { Conselho de Defesa do } \\
\text { Patrimônio Histórico, } \\
\text { Arqueológico, Artístico e } \\
\text { Turístico - CONDEPHAAT }\end{array}$ & Ubatuba \\
\hline $\begin{array}{c}\text { Tombamento da Serra do } \\
\text { Mar }\end{array}$ & $\begin{array}{c}\text { Resolução Estadual } 40 \text { de } \\
6 / 6 / 85\end{array}$ & $\begin{array}{l}\text { Conselho de Defesa do } \\
\text { Patrimônio Histórico, } \\
\text { Arqueológico, Artístico e } \\
\text { Turístico - CONDEPHAAT }\end{array}$ & $\begin{array}{l}\text { Ubatuba, Caraguatatuba, } \\
\text { São Sebastião e Illhabela }\end{array}$ \\
\hline $\begin{array}{c}\text { Área sob Proteção } \\
\text { Especial do Costão do } \\
\text { Navio }\end{array}$ & $\begin{array}{c}\text { Resolução da SMA de } \\
10 / 2 / 1987\end{array}$ & $\begin{array}{c}\text { Secretaria do Meio } \\
\text { Ambiente do Estado de } \\
\text { São Paulo }\end{array}$ & São Sebastião \\
\hline $\begin{array}{l}\text { Área sob Proteção } \\
\text { Especial do Cebimar }\end{array}$ & $\begin{array}{l}\text { Resolução Estadual da } \\
\text { SMA de 10/2/1987 }\end{array}$ & $\begin{array}{c}\text { Secretaria do Meio } \\
\text { Ambiente do Estado de } \\
\text { São Paulo } \\
\end{array}$ & São Sebastião \\
\hline $\begin{array}{c}\text { Área sob Proteção } \\
\text { Especial do Costão de } \\
\text { Boiçucanga }\end{array}$ & $\begin{array}{l}\text { Resolução Estadual da } \\
\text { SMA de } 11 / 2 / 1987\end{array}$ & $\begin{array}{c}\text { Secretaria do Meio } \\
\text { Ambiente do Estado de } \\
\text { São Paulo } \\
\end{array}$ & São Sebastião \\
\hline $\begin{array}{l}\text { Área Indígena Boa Vista } \\
\text { do Sertão do Prumirim }\end{array}$ & $\begin{array}{c}\text { Decreto Federal } 94.220 \text {, } \\
\text { de } 14 / 4 / 1987\end{array}$ & $\begin{array}{l}\text { Fundação Nacional do } \\
\text { Índio - FUNAI }\end{array}$ & Ubatuba \\
\hline $\begin{array}{c}\text { Área Indígena do Rio } \\
\text { Silveira }\end{array}$ & $\begin{array}{c}\text { Decreto Federal } 94.568, \\
\text { de } 8 / 7 / 1987 \\
\end{array}$ & $\begin{array}{c}\text { Fundação Nacional do } \\
\text { Índio - FUNAI } \\
\end{array}$ & São Sebastião \\
\hline $\begin{array}{l}\text { Estação Ecológica } \\
\text { Tupinambás }\end{array}$ & $\begin{array}{c}\text { Decreto Federal } 94.656 \text {, } \\
\text { de } 20 / 7 / 1987\end{array}$ & $\begin{array}{l}\text { Instituto Brasileiro de } \\
\text { Meio Ambiente e dos } \\
\text { Recursos Naturais } \\
\text { Renováveis - IBAMA }\end{array}$ & $\begin{array}{c}\text { Ubatuba, São Sebastião e } \\
\text { Ilhabela }\end{array}$ \\
\hline
\end{tabular}

Fonte: SMA-SP, 1996.

\subsubsection{Contexto Socioeconômico}

O litoral norte do estado de São Paulo representa uma área de exceção urbana dentro do contexto estadual, com predomínio de porções destinadas a diversas unidades de conservação: parques estaduais da Serra do Mar (PESM), de Ilhabela (PEIb) e da Ilha Anchieta (PEIA). O local apresenta um dos maiores resmanescentes de Mata Atlântica do país, com biodiversidade e geodiversidade exuberantes, atraentes para o turismo e para investimentos em educação ambiental.

A história socioeconômica da região está diretamente ligada aos fatores geográficos e aos recursos geológicos, tais como a instalação do porto em Ubatuba e posteriormente em São Sebastião, a exploração mineral e, a partir da década de 1950, o turismo. Este último, direcionado predominantemente ao turismo de sol e 
praia, gera, consequentemente, um aumento no número de residências secundárias na região (Tabela 2).

Tabela 2 - Número de residências secundárias por município no litoral norte de São Paulo.

\begin{tabular}{|c|c|c|c|c|}
\hline Municípios & 1980 & 1991 & 2000 & 2007 \\
\hline São Sebastião & $33,50 \%$ & $45,70 \%$ & $48,62 \%$ & $51,69 \%$ \\
\hline Ilhabela & $29,25 \%$ & $36,68 \%$ & $37,31 \%$ & $37,90 \%$ \\
\hline Caraguatatuba & $42,42 \%$ & $50,84 \%$ & $51,32 \%$ & $52,85 \%$ \\
\hline Ubatuba & $41,60 \%$ & $49,46 \%$ & $53,35 \%$ & $57,32 \%$ \\
\hline
\end{tabular}

Fonte: IBGE (2007).

O crescimento urbano desordenado a partir de 1950 gerou alguns problemas ambientais, como questões relativas ao esgotamento sanitário, resíduos sólidos, ocupação de encostas, enchentes, poluição, erosão e progradação costeira, redução dos estoques pesqueiros, entre outros (TEIXEIRA et al., 2011).

A população na região continua crescendo a uma taxa geométrica anual superior à média registrada para o Estado de São Paulo (2,26\% a.a. e 1,32\% a.a., respectivamente - SEADE, 2011). Associada a esta elevada taxa geométrica de crescimento anual da população fixa, soma-se o grande afluxo de turistas (população flutuante), principalmente durante a época de veraneio, sendo esta atividade a principal fonte de renda da região.

Segundo Scifoni (2006), são as atividades ligadas ao lazer, dentro deste conjunto mais amplo, que movimentam a economia dos municípios do litoral norte (Tabela 3). Os valores referentes à população flutuante na região representada pelos turistas são de 100.000 a 230.000 (SEADE, 2011) e revelam a importância do turismo na região.

Tabela 3 - Dados populacionais e econômicos dos municípios do litoral norte de São Paulo.

\begin{tabular}{|c|c|c|c|}
\hline Municípios & População (2016) & PIB per capita (2014) & IDHM (2010) \\
\hline São Sebastião & 84.294 & $\mathrm{R} \$ 64.304,91$ & 0,772 \\
\hline Ilhabela & 32.782 & $\mathrm{R} \$ 214.314,27$ & 0,756 \\
\hline Caraguatatuba & 115.071 & $\mathrm{R} \$ 25.871,05$ & 0,759 \\
\hline Ubatuba & 87.364 & $\mathrm{R} \$ 19.420,59$ & 0,751 \\
\hline
\end{tabular}

Fonte: IBGE, 2017.

Sendo o turismo, antes de tudo, uma troca cultural, seu crescimento demanda investimentos em infraestrutura cultural, tais como museus, exposições e casas de cultura. Na Tabela 4 são apresentados alguns dados econômicos e sociais da região que permitem relacionar o potencial econômico dos moradores com a cultura local. 
Tabela 4 - Dados econômicos e sociais dos municípios do litoral norte de São Paulo.

\begin{tabular}{|c|c|c|c|}
\hline Municípios (2011) & $\begin{array}{c}\text { Centros Culturais, } \\
\text { casas e espaços de } \\
\text { cultura }\end{array}$ & $\begin{array}{c}\text { Gasto em cultura per } \\
\text { capita R\$/habitante }\end{array}$ & $\begin{array}{c}\text { População flutuante } \\
\text { média aproximada }\end{array}$ \\
\hline São Sebastião & 32 & 194,16 & 230.000 \\
\hline Ilhabela & 28 & 90,65 & 100.000 \\
\hline Caraguatatuba & 12 & 25,65 & 100.000 \\
\hline Ubatuba & 90 & Sem dados & 117.000 \\
\hline
\end{tabular}

Fonte: SEADE, 2011.

A região abriga também comunidades tradicionais que representam a história viva do Brasil, constituídas por caiçaras, quilombolas e indígenas. Devido à relação direta que têm com a natureza e, por conseguinte, a alta preservação dos locais onde vivem, estas populações são constantemente ameaçadas pela especulação imobiliária.

Dentre os povos tradicionais que habitam a região estão os caiçaras, originados da miscigenação índio/colono, e que se estabeleceram nos costões rochosos, restingas, mangues e encostas da Serra do Mar. As comunidades caiçaras possuem forte ligação com a natureza e durante quase um século viveram isoladas (FUNDART, 2017). Atualmente, vivem cercadas pelo meio urbano e muitas vezes marginalizadas pelo crescimento imobiliário.

As comunidades quilombolas da região localizam-se predominantemente no município de Ubatuba: Caçandoca, Camburi, Fazenda e Sertão do Itamambuca. Esses quilombos originaram-se pela demanda de escravos advindos da África durante o período cafeeiro no sudeste brasileiro. Com o declínio do café na segunda metade do século XIX, muitas fazendas foram abandonadas e os quilombos ali permaneceram. Muitos foram expulsos da terra e os que permanecem travam até hoje uma constante batalha com empresas imobiliárias.

A população indígena é bastante significativa na região (Figura 3). Segundo o censo demográfico do IBGE (2010), o litoral norte conta com uma população indígena total de 814 pessoas, algumas vivendo em áreas indígenas protegidas, como a Área Indígena Boa Vista do Sertão do Prumirim, em Ubatuba, e a Área Indígena do Rio Silveira, localizada na divisa do município de São Sebastião com Bertioga. 


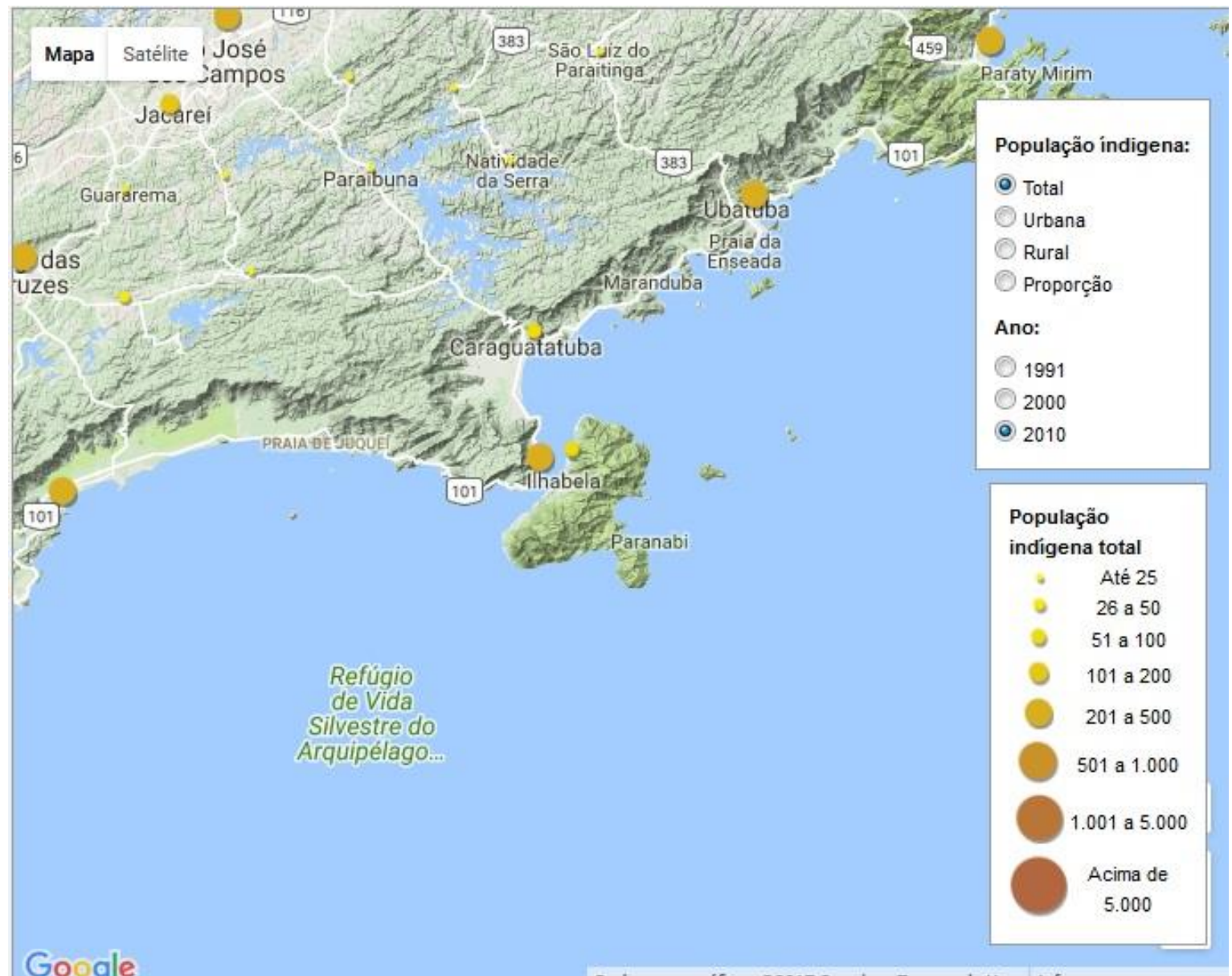

Figura 3 - Mapa demográfífico da póficos @2017 Google Termos de Uso Informar errono mapa IBGE, 2010. 


\section{MATERIAIS E MÉTODOS}

\subsection{LEVANTAMENTO DE DADOS}

Nesta etapa foram coletadas informações sobre a área de estudo, desde a geodiversidade à história e cultura da região, através de pesquisa bibliográfica, consulta em sites da internet, trabalhos de campo, entrevista com pesquisadores e moradores da região, com a finalidade de identificar sítios potenciais que pudessem ser incluídos no inventário. Com base nesta pesquisa inicial, foram realizados trabalhos de campo com o objetivo de avaliar os sítios pré-selecionados e investigar possíveis novos sítios.

As informações e dados levantados foram classificados em quatro grupos: geossítios, sítios da geodiversidade, patrimônio construído e patrimônio cultural (Tabela 5).

Tabela 5 - Levantamento de dados de sítios potenciais.

\begin{tabular}{|c|c|}
\hline Sítios Potenciais & Levantamento de dados \\
\hline Geossítios & Mapas geológicos, teses, artigos, trabalhos de campo, entrevista com pesquisadores. \\
\hline $\begin{array}{c}\text { Sítios da } \\
\text { Geodiversidade }\end{array}$ & $\begin{array}{c}\text { Teses, artigos, sites de turismo, trabalhos de campo, entrevista com pesquisadores e } \\
\text { moradores da região. }\end{array}$ \\
\hline $\begin{array}{c}\text { Patrimônio } \\
\text { Construído }\end{array}$ & Teses, artigos, tombamentos patrimoniais e trabalhos de campo. \\
\hline $\begin{array}{c}\text { Patrimônio } \\
\text { Cultural }\end{array}$ & $\begin{array}{r}\text { Institutos e Fundações de Cultura (IPHAN, Fundart, Fundacc, etc.), trabalhos de campo } \\
\text { e entrevistas com representantes de comunidades tradicionais. }\end{array}$ \\
\hline
\end{tabular}

\subsection{SELEÇÃo E AVALIAÇÃo QUANTITATIVA DE GEOSSÍtIOS EM CARAGUATATUBA}

A escolha do município de Caraguatatuba está relacionada com as demais pesquisas já realizadas pelo GeoHereditas, onde nos outros 3 municípios da área de estudo já existe um inventário (PROCHOROFF, 2014; SANTOS, 2014; REVERTE, 2014), restando apenas este munícipio para complementar o levantamento do patrimônio geológico do litoral norte. Para a seleção dos geossítios no município de Caraguatatuba utilizou-se como base cartográfica o Mapa Geológico do estado de São Paulo (PERROTTA et al., 2005). A partir da pré-seleção de locais de interesse através de mapas geológicos, pesquisa bibliográfica, entrevista com pesquisadores e moradores da região e trabalhos de campo, foi realizado o inventário do patrimônio geológico do município (ARRUDA et al., 2015) por meio da seleção dos sítios que 
apresentaram valor científico maior que 200 na avaliação quantitativa (ROCHA et al., 2016).

A avaliação quantitativa foi realizada através do Geossit (ROCHA et al., 2016), uma plataforma online desenvolvida pelo Serviço Geológico do Brasil e inicialmente baseada nos métodos de Brilha (2005) e Garcia-Cortés \& Urqui (2009). Atualmente está reestruturada com adaptações ao método de Brilha (2016). Para os geossítios de Caraguatatuba foram avaliados o valor científico (VC) (Tabela 6), o Risco de Degradação (Rd) (Tabela 7) e os potenciais de uso educacional (Pe) e uso turístico (Pt) (Tabela 8). Os valores foram calculados de acordo com o peso estabelecido em cada critério (Tabela 9).

Tabela 6 - Critérios e parâmetros para a quantificação do Valor Científico dos geossítios.

\begin{tabular}{|c|c|}
\hline \multicolumn{2}{|r|}{ Valor Científico (VC) } \\
\hline Critérios (peso \%) & Pontos/Parâmetros \\
\hline \multirow{3}{*}{$\begin{array}{l}\text { A- } \\
\text { Representatividade } \\
(30 \%)\end{array}$} & $\begin{array}{l}4 \text { - O geossítio é o melhor exemplo na área de estudo para ilustrar elementos ou processos, } \\
\text { relacionado com a temática geológica em consideração (quando aplicável). }\end{array}$ \\
\hline & $\begin{array}{l}2 \text { - O geossítio é um bom exemplo na área de estudo para ilustrar elementos ou processos, } \\
\text { relacionado com a temática geológica em consideração (quando aplicável). }\end{array}$ \\
\hline & $\begin{array}{l}1 \text { - O geossítio ilustra razoavelmente elementos ou processos na área de estudo, relacionado com } \\
\text { a temática geológica em consideração (quando aplicável). }\end{array}$ \\
\hline \multirow[t]{3}{*}{ B - Local-tipo (20\%) } & $\begin{array}{l}4 \text { - O geossítio é reconhecido como um GSSP ou ASSP pela IUGS ou é um sítio de referência no } \\
\text { IMA. }\end{array}$ \\
\hline & $\begin{array}{l}2 \text { - O geossítio é utilizado pela ciência internacional, diretamente relacionado com a temática } \\
\text { geológica em consideração (quando aplicável). }\end{array}$ \\
\hline & $\begin{array}{l}1 \text { - O geossítio é usado pela ciência nacional, diretamente relacionado com a temática geológica } \\
\text { em consideração (quando aplicável). }\end{array}$ \\
\hline \multirow[t]{3}{*}{$\begin{array}{l}\text { C-Conhecimento } \\
\text { Científico }(5 \%)\end{array}$} & $\begin{array}{l}4 \text { - Existem artigos em jornais científicos internacionais sobre esse geossítio, diretamente } \\
\text { relacionado com a temática geológica em consideração (quando aplicável). }\end{array}$ \\
\hline & $\begin{array}{l}2 \text { - Existem artigos em publicações científicas nacionais sobre esse geossítio, diretamente } \\
\text { relacionado com a temática geológica em consideração (quando aplicável). }\end{array}$ \\
\hline & $\begin{array}{l}1 \text { - Existem resumos apresentados em eventos científicos internacionais sobre esse geossítio, } \\
\text { diretamente relacionado com a temática geológica em consideração (quando aplicável). }\end{array}$ \\
\hline \multirow[t]{3}{*}{$\begin{array}{l}\text { D - Integridade } \\
(15 \%)\end{array}$} & $\begin{array}{l}4 \text { - Os principais elementos geológicos (relacionado com a temática geológica em consideração, } \\
\text { quando aplicável) estão muito bem preservados. }\end{array}$ \\
\hline & $\begin{array}{l}2 \text { - Geossítio não tão bem preservado, mas os principais elementos geológicos (relacionado com a } \\
\text { temática geológica em consideração, quando aplicável) ainda estão preservados. }\end{array}$ \\
\hline & $\begin{array}{l}\text { 1- Geossítio com problemas de preservação e com os principais elementos geológicos (relacionado } \\
\text { com a temática geológica em consideração, quando aplicável) muito alterados ou modificados. }\end{array}$ \\
\hline \multirow[t]{3}{*}{$\begin{array}{l}\text { E- Diversidade } \\
\text { Geológica (5\%) }\end{array}$} & $\begin{array}{l}4 \text { - Geossítio com mais de três tipos de características geológicas distintas com relevância } \\
\text { científica. }\end{array}$ \\
\hline & 2-Geossítio com três tipos de características geológicas distintas com relevância científica. \\
\hline & 1-Geossítio com dois tipos de características geológicas distintas com relevância científica. \\
\hline \multirow[t]{3}{*}{ F-Raridade (15\%) } & $\begin{array}{l}4 \text { - O geossítio é a única ocorrência desse tipo na área de estudo (representando a temática } \\
\text { geológica em consideração, quando aplicável). }\end{array}$ \\
\hline & $\begin{array}{l}2 \text { - Na área de estudo existem dois ou três exemplos de geossítios similiares (representando a } \\
\text { temática geológica em consideração, quando aplicável). }\end{array}$ \\
\hline & $\begin{array}{l}1 \text { - Na área de estudo, existem quatro ou cinco exemplos de geossítios similares (representando a } \\
\text { temática geológica em consideração, quando aplicável). }\end{array}$ \\
\hline \multirow[t]{3}{*}{$\begin{array}{l}\text { G- Limitações de } \\
\text { Uso (10\%) }\end{array}$} & $\begin{array}{l}4 \text { - O geossítio não possui limitações (permissões legais, barreiras físicas,...) para coleta de } \\
\text { amostras ou campo. }\end{array}$ \\
\hline & 2-É possível coletar amostras e fazer campo depois de ultrapassar as limitações. \\
\hline & $\begin{array}{l}1 \text { - Campo e amostragens são muito difíceis de serem realizados devido a dificuldades de } \\
\text { limitações (permissões legais, barreiras físicas, ...). }\end{array}$ \\
\hline
\end{tabular}
Fonte: ROCHA et al. (2016). 
No inventário do município de Caraguatatuba foi utilizada a tipologia espacial de geossítios definida a partir do método descrito em Fuertes-Gutiérrez \& Fernández-Martínez (2010), que definem cinco tipos de geossítios de acordo com seu tamanho e extensão: Pontual, Seção, Área, Mirante e Área Complexa. Os elementos geológicos dos geossítios foram descritos com base nas opções de tipologia existentes no formulário de propostas da Comissão Brasileira de Sítios Geológicos e Paleontológicos - SIGEP. Todo o processo de inventário e avaliação quantitativa do patrimônio geológico de Caraguatuba está descrito no Anexo 1.

Tabela 7 - Critérios e parâmetros de quantificação do Risco de Degradação.

\begin{tabular}{|c|c|}
\hline \multicolumn{2}{|r|}{ Risco de Degradação } \\
\hline Critérios (peso\%) & Parâmetros \\
\hline \multirow{4}{*}{$\begin{array}{l}\text { B1 - Deterioração de } \\
\text { elementos geológicos } \\
(35 \%)\end{array}$} & 4 pontos - Possibilidade de deterioração de todos os elementos geológicos \\
\hline & 3 pontos - Possiblidade de deterioração dos principais elementos geológicos \\
\hline & 2 pontos - Possibilidade de deterioração dos elementos geológicos secundários \\
\hline & $\begin{array}{l}1 \text { ponto - Existem reduzidas possibilidades de deterioração dos elementos geológicos } \\
\text { secundários }\end{array}$ \\
\hline \multirow{4}{*}{$\begin{array}{l}\text { B2 - Proximidade a } \\
\text { áreas/atividades com } \\
\text { potencial para causar } \\
\text { degradação (20\%) }\end{array}$} & $\begin{array}{l}4 \text { pontos - Local de interesse situado a menos de } 100 \mathrm{~m} \text { de área/atividade com potencial para } \\
\text { causar degradação }\end{array}$ \\
\hline & $\begin{array}{l}3 \text { pontos - Local de interesse situado a menos de } 500 \mathrm{~m} \text { de área/atividade com potencial para } \\
\text { causar degradação }\end{array}$ \\
\hline & $\begin{array}{l}2 \text { pontos - Local de interesse situado a menos de } 1000 \mathrm{~m} \text { de área/atividade com potencial para } \\
\text { causar degradação }\end{array}$ \\
\hline & $\begin{array}{l}1 \text { ponto - Local de interesse situado a mais de } 1000 \mathrm{~m} \text { de área/atividade com potencial para } \\
\text { causar degradação }\end{array}$ \\
\hline \multirow{4}{*}{$\begin{array}{l}\text { B3 - Proteção legal } \\
(20 \%)\end{array}$} & 4 pontos - Local de interesse situado numa área sem proteção legal nem controle de acesso \\
\hline & $\begin{array}{l}3 \text { pontos - Local de interesse situado numa área sem proteção legal, mas com controle de } \\
\text { acesso }\end{array}$ \\
\hline & $\begin{array}{l}2 \text { pontos - Local de interesse situado numa área com proteção legal, mas sem controle de } \\
\text { acesso }\end{array}$ \\
\hline & 1 ponto - Local de interesse situado numa área com proteção legal e com controle de acesso. \\
\hline \multirow{4}{*}{$\begin{array}{l}\text { B4 - Acessibilidade } \\
(15 \%)\end{array}$} & $\begin{array}{l}4 \text { pontos - Local de interesse localizado a menos de } 100 \mathrm{~m} \text { de uma estrada asfaltada com local } \\
\text { para estacionamento de veículos }\end{array}$ \\
\hline & 3 pontos - Local de interesse localizado a menos de $500 \mathrm{~m}$ de uma estrada asfaltada \\
\hline & 2 pontos - Local de interesse acessível por veículo em estrada não asfaltada \\
\hline & $\begin{array}{l}1 \text { ponto - Local de interesse sem acesso direto por estrada, mas situado a menos de } 1 \mathrm{~km} \text { de } \\
\text { uma estrada acessível por veículos }\end{array}$ \\
\hline \multirow{4}{*}{$\begin{array}{l}\text { B5 - Densidade } \\
\text { populacional } \\
(10 \%)\end{array}$} & 4 pontos - Local de interesse localizado num município com mais de 1000 habitantes por km² \\
\hline & 3 pontos - Local de interesse localizado num município com 250-1000 habitantes por km² \\
\hline & 2 pontos - Local de interesse localizado num município com $100-250$ habitantes por $\mathrm{km}^{2}$ \\
\hline & 1 ponto - Local de interesse localizado num município com menos de 100 habitantes por km² \\
\hline
\end{tabular}

Fonte: ROCHA et al. (2016). 
Tabela 8 - Critérios e parâmetros para a quantificação do Potencial de uso educacional e turístico dos geossítios.

\begin{tabular}{|c|c|}
\hline \multicolumn{2}{|r|}{ Potencial Uso Educativo e Turístico } \\
\hline Critérios & Parâmetros \\
\hline \multirow{4}{*}{ C1 - Vulnerabilidade } & $\begin{array}{l}4 \text { pontos - Os elementos geológicos do local de interesse não apresentam possibilidade de } \\
\text { deterioração por atividades antrópicas. }\end{array}$ \\
\hline & $\begin{array}{l}3 \text { pontos - Possibilidade de deterioração de elementos geológicos secundários por atividade } \\
\text { antrópica. }\end{array}$ \\
\hline & $\begin{array}{l}2 \text { pontos - Possibilidade de deterioração dos principais elementos geológicos por atividade } \\
\text { antrópica. }\end{array}$ \\
\hline & $\begin{array}{l}1 \text { ponto - Possibilidade de deterioração de todos os elementos geológicos por atividade } \\
\text { antrópica. }\end{array}$ \\
\hline \multirow{4}{*}{ C2 - Acessibilidade } & $\begin{array}{l}4 \text { pontos - Local de interesse localizado a menos de } 100 \text { m de uma estrada asfaltada com } \\
\text { local para estacionamento de veículos. }\end{array}$ \\
\hline & 3 pontos - Local de interesse localizado a menos de 500 m de uma estrada asfaltada. \\
\hline & 2 pontos - Local de interesse acessível por veículo em estrada não asfaltada. \\
\hline & $\begin{array}{l}1 \text { ponto - Local de interesse sem acesso direto pela estrada, mas situado a menos de } 1 \mathrm{~km} \text { de } \\
\text { uma estrada acessível por veículo. }\end{array}$ \\
\hline \multirow{4}{*}{$\begin{array}{l}\text { C3 - Limitações ao } \\
\text { uso }\end{array}$} & 4 pontos - O local de interesse não tem limitações para ser usado por estudantes e turistas. \\
\hline & $\begin{array}{l}3 \text { pontos - O local de interesse pode ser usado por estudantes e turistas, mas apenas } \\
\text { ocasionalmente. }\end{array}$ \\
\hline & $\begin{array}{l}2 \text { pontos - O local de interesse pode ser usado por estudantes e turistas, mas só depois de } \\
\text { ultrapassar certas limitações (autorização, barreiras físicas, marés, inundações, etc.). }\end{array}$ \\
\hline & $\begin{array}{l}1 \text { ponto - O uso por estudantes e turistas é muito difícil de conseguir devido à dificuldade em } \\
\text { ultrapassar certas limitações (autorização, barreiras físicas, marés, inundações, etc.). }\end{array}$ \\
\hline \multirow{4}{*}{ C4 - Segurança } & $\begin{array}{l}4 \text { pontos - Local de interesse com infraestrutura de segurança (vedações, escadas, corrimãos, } \\
\text { etc.), rede de comunicações móveis e situado a menos de } 10 \mathrm{~km} \text { de serviços de socorro. }\end{array}$ \\
\hline & $\begin{array}{l}3 \text { pontos - Local de interesse com infraestrutura de segurança (vedações, escadas, corrimãos, } \\
\text { etc.), rede de comunicações móveis e situado a menos de } 25 \mathrm{~km} \text { de serviços de socorro. }\end{array}$ \\
\hline & $\begin{array}{l}2 \text { pontos - Local de interesse sem infraestrutura de segurança (vedações, escadas, corrimãos, } \\
\text { etc.), mas com rede de comunicações móveis e situado a menos de } 50 \mathrm{Km} \text { de serviços de } \\
\text { socorro. }\end{array}$ \\
\hline & $\begin{array}{l}1 \text { ponto - Local de interesse sem infraestrutura de segurança (vedações, escadas, corrimãos, } \\
\text { etc.), nem rede de comunicações móveis e situado a mais de } 50 \mathrm{~km} \text { de serviços de socorro. }\end{array}$ \\
\hline \multirow{4}{*}{ C5 - Logística } & $\begin{array}{l}4 \text { pontos - Existem restaurantes e alojamentos para grupos de } 50 \text { pessoas a menos de } 15 \mathrm{~km} \\
\text { do local de interesse. }\end{array}$ \\
\hline & $\begin{array}{l}3 \text { pontos - Existem restaurantes e alojamentos para grupos de } 50 \text { pessoas a menos de } 50 \mathrm{~km} \\
\text { do local de interesse. }\end{array}$ \\
\hline & $\begin{array}{l}2 \text { pontos - Existem restaurantes e alojamentos para grupos de } 50 \text { pessoas a menos de } 100 \\
\mathrm{~km} \text { do local de interesse. }\end{array}$ \\
\hline & $\begin{array}{l}1 \text { ponto - Existem restaurantes e alojamentos para grupos de até } 25 \text { pessoas a menos de } 50 \\
\mathrm{~km} \text { do local de interesse. }\end{array}$ \\
\hline \multirow{4}{*}{$\begin{array}{l}\text { C6 - Densidade } \\
\text { populacional }\end{array}$} & $\begin{array}{l}4 \text { pontos - Local de interesse localizado num município com mais de } 1000 \text { habitantes por } \\
\mathrm{km}^{2} .\end{array}$ \\
\hline & 3 pontos - Local de interesse localizado num município com 250-1000 habitantes por km². \\
\hline & 2 pontos - Local de interesse localizado num município com 100-250 habitantes por km². \\
\hline & 1 ponto - Local de interesse localizado num município com menos de 100 habitantes por km². \\
\hline \multirow{2}{*}{$\begin{array}{l}\text { C7 - Associação com } \\
\text { outros valores }\end{array}$} & $\begin{array}{l}4 \text { pontos - Existem diversos valores ecológicos e culturais a menos de } 10 \mathrm{~km} \text { do local de } \\
\text { interesse. }\end{array}$ \\
\hline & $\begin{array}{l}3 \text { pontos - Existem diversos valores ecológicos e culturais a menos de } 20 \mathrm{~km} \text { do local de } \\
\text { interesse. }\end{array}$ \\
\hline
\end{tabular}




\begin{tabular}{|c|c|}
\hline & $\begin{array}{l}2 \text { pontos - Existe um valor ecológico e um valor cultural a menos de } 20 \mathrm{~km} \text { do local de } \\
\text { interesse. }\end{array}$ \\
\hline & 1 ponto - Existe um valor ecológico ou um cultural a menos de $20 \mathrm{~km}$ do local de interesse. \\
\hline \multirow{4}{*}{ C8 - Beleza cênica } & $\begin{array}{l}4 \text { pontos - Local de interesse habitualmente usado em campanhas turísticas do país, } \\
\text { mostrando aspectos geológicos. }\end{array}$ \\
\hline & $\begin{array}{l}3 \text { pontos - Local de interesse ocasionalmente usado em campanhas turísticas do país, } \\
\text { mostrando aspectos geológicos. }\end{array}$ \\
\hline & $\begin{array}{l}2 \text { pontos - Local de interesse habitualmente usado em campanhas turísticas locais, } \\
\text { mostrando aspectos geológicos. }\end{array}$ \\
\hline & $\begin{array}{l}1 \text { ponto - Local de interesse ocasionalmente usado em campanhas turísticas locais, } \\
\text { mostrando aspectos geológicos. }\end{array}$ \\
\hline \multirow{4}{*}{ C9 -Singularidade } & 4 pontos - Ocorrência de aspectos únicos e raros no país. \\
\hline & 3 pontos - Ocorrência de aspectos únicos e raros no estado. \\
\hline & 2 pontos - Ocorrência de aspectos únicos e raros na região. \\
\hline & 1 ponto - Ocorrência de aspectos comuns nas várias regiões do país. \\
\hline \multirow{4}{*}{$\begin{array}{l}\text { C10 - Condições de } \\
\text { observação }\end{array}$} & 4 pontos - A observação de todos elementos geológicos é feita em boas condições. \\
\hline & $\begin{array}{l}3 \text { pontos - Existem obstáculos que tornam difícil a observação de alguns elementos } \\
\text { geológicos. }\end{array}$ \\
\hline & $\begin{array}{l}2 \text { pontos - Existem alguns obstáculos que tornam difícil a observação dos principais } \\
\text { elementos geológicos. }\end{array}$ \\
\hline & $\begin{array}{l}1 \text { ponto - Existem alguns obstáculos que praticamente impossibilitam a observação dos } \\
\text { principais elementos geológicos. }\end{array}$ \\
\hline \multirow{4}{*}{$\begin{array}{l}\text { C11 - Potencial } \\
\text { didático }\end{array}$} & $\begin{array}{l}4 \text { pontos - Ocorrência de elementos geológicos que são ensinados em todos os níveis de } \\
\text { ensino. }\end{array}$ \\
\hline & $\begin{array}{l}3 \text { pontos - Ocorrência de elementos geológicos que são ensinados nas escolas de ensino } \\
\text { básico. }\end{array}$ \\
\hline & $\begin{array}{l}2 \text { pontos - Ocorrência de elementos geológicos que são ensinados nas escolas de ensino } \\
\text { secundário. }\end{array}$ \\
\hline & 1 ponto - Ocorrência de elementos geológicos que são ensinados no ensino superior. \\
\hline \multirow{4}{*}{$\begin{array}{l}\text { C12 - Diversidade } \\
\text { geológica }\end{array}$} & $\begin{array}{l}4 \text { pontos - Ocorrem mais de } 5 \text { tipos de elementos da geodiversidade (mineralógicos, } \\
\text { paleontológicos, geomorfológico, etc.). }\end{array}$ \\
\hline & 3 pontos - Ocorrem 3 ou 4 tipos de elementos da geodiversidade. \\
\hline & 2 pontos - Ocorrem 2 tipos de elementos da geodiversidade. \\
\hline & 1 ponto - Ocorre apenas 1 tipo de elemento da geodiversidade. \\
\hline \multirow{4}{*}{$\begin{array}{l}\text { C13 - Potencial para } \\
\text { divulgação }\end{array}$} & $\begin{array}{l}4 \text { pontos - Ocorrência de elementos geológicos que são evidentes e perceptíveis para todos } \\
\text { os tipos de público. }\end{array}$ \\
\hline & $\begin{array}{l}3 \text { pontos - O público necessita de algum conhecimento geológico para entender os } \\
\text { elementos geológicos que ocorrem no sítio. }\end{array}$ \\
\hline & $\begin{array}{l}2 \text { pontos - O público necessita de bons conhecimentos geológicos para entender os } \\
\text { elementos geológicos que ocorrem no sítio. }\end{array}$ \\
\hline & $\begin{array}{l}1 \text { pontos - Os elementos geológicos que ocorrem no sítio são evidentes e perceptíveis para } \\
\text { quem possui graduação em geociências. }\end{array}$ \\
\hline \multirow{4}{*}{$\begin{array}{l}\text { C14 - Nível } \\
\text { econômico }\end{array}$} & $\begin{array}{l}4 \text { pontos - Local de interesse localizado num município com pelo menos o dobro do IDH que } \\
\text { se verifica no estado. }\end{array}$ \\
\hline & $\begin{array}{l}3 \text { pontos - Local de interesse localizado num município com IDH superior ao que se verifica } \\
\text { no estado. }\end{array}$ \\
\hline & $\begin{array}{l}2 \text { pontos - Local de interesse localizado num município com IDH idêntico ao que se verifica no } \\
\text { estado. }\end{array}$ \\
\hline & $\begin{array}{l}1 \text { ponto - Local de interesse localizado num município com IDH inferior ao que se verifica no } \\
\text { estado. }\end{array}$ \\
\hline $\begin{array}{l}\text { C15 - Proximidade } \\
\text { com zonas }\end{array}$ & $\begin{array}{l}4 \text { pontos - Local de interesse localizado a menos de } 5 \mathrm{~km} \text { de uma zona recreativa ou com } \\
\text { atrações turísticas. }\end{array}$ \\
\hline
\end{tabular}




\begin{tabular}{|l|l|}
\hline recreativas & $\begin{array}{l}3 \text { pontos - Local de interesse localizado a menos de } 10 \mathrm{~km} \text { de uma zona recreativa ou com } \\
\text { atrações turísticas. }\end{array}$ \\
\cline { 2 - 2 } & $\begin{array}{l}2 \text { pontos - Local de interesse localizado a menos de } 15 \mathrm{~km} \text { de uma zona recreativa ou com } \\
\text { atrações turísticas. }\end{array}$ \\
\cline { 2 - 2 } & $\begin{array}{l}1 \text { ponto - Local de interesse localizado a menos de } 20 \mathrm{~km} \text { de uma zona recreativa ou com } \\
\text { atrações turísticas. }\end{array}$ \\
\hline
\end{tabular}

Fonte: ROCHA et al. (2016).

Tabela 9 - Pesos dos critérios de avaliação do potencial de uso educativo e turístico.

\begin{tabular}{|l|l|l|}
\hline \multicolumn{3}{|c|}{ Potencial de Uso Educativo e Turístico } \\
\hline & $\begin{array}{l}\text { Educativo } \\
\text { (Peso \%) }\end{array}$ & $\begin{array}{l}\text { Turístico } \\
\text { (Peso \%) }\end{array}$ \\
\hline C1- Vulnerabilidade & $10 \%$ & $10 \%$ \\
\hline C2 - Acessibilidade & $10 \%$ & $10 \%$ \\
\hline C3 - Limitações ao uso & $5 \%$ & $5 \%$ \\
\hline C4 - Segurança & $10 \%$ & $10 \%$ \\
\hline C5 - Logística & $5 \%$ & $5 \%$ \\
\hline C6 - Densidade populacional & $5 \%$ & $5 \%$ \\
\hline C7 - Associação com outros valores & $5 \%$ & $5 \%$ \\
\hline C8 - Beleza cênica & $5 \%$ & $15 \%$ \\
\hline C9 - Singularidade & $5 \%$ & $10 \%$ \\
\hline C10 - Condições de observação & $10 \%$ & $5 \%$ \\
\hline C11 - Potencial didático & $20 \%$ & - \\
\hline C12 - Diversidade geológica & $10 \%$ & - \\
\hline C13 - Potencial para divulgação & - & $10 \%$ \\
\hline C14 - Nível econômico & - & $5 \%$ \\
\hline C15 - Proximidade a zonas recreativas & - & $5 \%$ \\
\hline Total & $100 \%$ & $100 \%$ \\
\hline
\end{tabular}

Fonte: ROCHA et al. (2016).

\subsection{AVALIAÇÃO QUANTITATIVA DOS GEOSSítIOS EM OUTROS MUNICÍPIOS}

O inventário e a avaliação quantitativa dos municípios de São Sebastião, Ilhabela e Ubatuba foram realizados em Reverte (2014), Prochoroff (2014) e Santos (2014), respectivamente, utilizando a plataforma GEOSSIT, baseada nos métodos de Brilha (2005) e Garcia-Cortés \& Urqui (2009).

Para a integração geral do patrimônio geológico de todo o litoral norte de São Paulo, este trabalho optou por manter um padrão no método de avaliação quantitativa do pontencial de uso dos geossítios. Deste modo, os geossítios inventariados em Reverte (2014), Prochoroff (2014) e Santos (2014) tiveram o potencial de uso educativo e turístico quantificados neste trabalho através do método atualizado em 2016 da plataforma GEOSSIT (ROCHA et al., 2016). 


\subsection{SELEÇÃO E AVALIAÇÃO QUANTITATIVA DOS SítIOS DA GEODIVERSIDADE}

O método de seleção dos sítios da geodiversidade neste trabalho foi feito com base em três etapas (disponível integralmente no Anexo B). Após a seleção dos sítios foi realizada a avaliação quantitativa do potencial de uso educativo e turístico atráves da plataforma GEOSSIT (ROCHA et al., 2016).

$\mathrm{Na}$ primeira etapa foi realizada a pré-seleção de pontos com base em pesquisas e levantamentos em sites de turismo, materiais divulgativos, livros, trabalhos acadêmicos e entrevistas com pesquisadores, apresentando um total de 55 sítios pré-selecionados. Na segunda etapa foi realizada a seleção parcial dos sítios pré-selecionados, onde foram eliminados os sítios que não se enquadravam na definição de sítio da geodiversidade, por não apresentarem acessibilidade, segurança ou potencial educativo ou turístico suficientes. Por fim, na seleção final, os sítios selecionados na etapa anterior foram investigados a partir de trabalhos de campo a fim de conferir sua potencialidade. Os pontos que não apresentaram no campo acessibilidade, segurança, ou potencial educativo e/ou turístico adequados foram eliminados. A lista final resultou em 25 sítios da geodiversidade distribuídos nos quatro municípios do litoral norte (Anexo 2).

\subsection{SELEÇÃO DO PATRIMÔNIO CONSTRUÍDO}

Para a seleção do patrimônio construído foi realizado um levantamento bibliográfico em teses, artigos e tombamentos patrimoniais, a fim de fazer uma préseleção de construções representativas na história do litoral norte do estado de São Paulo que utilizaram material pétreo em sua construção. Este levantamento resultou em um total de 31 pontos. A partir de trabalhos de campo foram eliminadas as construções que não apresentaram relevância geológica em seus materiais de construção e/ou de revestimento. A eliminação levou em consideração também a acessibilidade (fácil localização, disponibilidade de acesso e tipo de propriedade). Após este processo, 13 pontos foram selecionados e receberam a denominação de patrimônio construído (ARRUDA et al., 2017, Anexo C) por apresentarem materiais pétreos relevantes para a história da utilização das rochas na região, proveniência e importação do material. 


\section{INVENTÁRIO E QUANTIFICAÇÃO DO PATRIMÔNIO GEOLÓGICO DO MUNICÍPIO DE CARAGUATATUBA, SÃO PAULO, BRASIL}

Artigo publicado: ARRUDA, K.E.C; GARCIA, M.G.M; DEL LAMA, E.A. 2017b. Inventário e Avaliação Quantitativa do Patrimônio Geológico do município de Caraguatatuba, São Paulo. Geociências, UNESP, São Paulo, 36 (3): 447 - 462. Disponível no Anexo A.

\section{RESUMO}

O município de Caraguatatuba apresenta uma rica geodiversidade relacionada à amalgamação e fragmentação do Supercontinente Gondwana. A ausência de estudos geológicos detalhados, associada à falta de informação e à ameaça da urbanização desordenada justifica a necessidade de um inventário do patrimônio geológico do município. A partir de pesquisa bibliográfica e trabalhos de campo foram definidos sete geossítios: Praia Brava, Megaboudin da Lagoa Azul, Milonitos da Tabatinga-llha do Tamanduá, Milonitos e Cataclasitos da Estrada da Petrobras, Morro do Santo Antônio, Geoformas de Caraguatatuba e Registros da Catástrofe. A quantificação forneceu as pontuações para valor científico, potencial para uso educacional e turístico e para risco de degradação. A partir dos resultados, concluise que os geossítios com elementos geomorfológicos apresentaram pontuações mais altas para pontencial de uso educacional e turístico. O geossítio Morro do Santo Antônio obteve a maior pontuação em valor científico e risco de degradação. Os dados obtidos neste trabalho são parte de um projeto maior que abrange o inventário do patrimônio geológico da região costeira do estado de São Paulo e base de um projeto que visa aplicar o geoturismo no litoral norte. Os dados serão utilizados como ferramenta de auxílio para gestão territorial e implementação de estratégias de geoconservação.

Palavras-Chave: Caraguatatuba; Inventário; Patrimônio Geológico; Quantificação. 


\section{MÉTOdo dE SELEÇÃO E PROPOSTAS DE USO DOS SÍtIOS DA GEODIVERSIDADE: EXEMPLO DO LITORAL NORTE DO ESTADO DE SÃO PAULO, BRASIL}

Artigo publicado: ARRUDA, K.E.C; GARCIA, M.G.M; DEL LAMA, E.A.; MUCIVUNA, V.C; REVERTE, F.C. 2017c. Método de Seleção e Propostas de Uso dos Sítios da Geodiversidade: Exemplo do Litoral Norte do Estado de São Paulo, Brasil. Anuário do Instituto de Geociências .UFRJ, Rio de Janeiro. 40 (3): 32 - 56. Disponível no Anexo B.

\section{RESUMO}

A geodiversidade há tempos sofre as consequências antrópicas da falta de informação acerca da sua importância, sendo colocada em segundo plano nas políticas de conservação da natureza e valorizada apenas pela extração de seus recursos. No início do século XIX, a criação de alguns parques nacionais no mundo, tendo como atração principal a geodiversidade, mostrou que essa situação pode mudar se investirmos no potencial de uso de alguns locais da geodiversidade. Deste modo, surgem os "sítios da geodiversidade", locais que apresentam potencial para uso educativo e turístico com oferta de informação geológica. Este trabalho objetiva apresentar o método utilizado para a seleção dos sítios da geodiversidade do litoral norte do estado de São Paulo e discutir os resultados de sua quantificação para tecer propostas de uso para estes locais. A seleção dos sítios baseou-se em três etapas: i) pré-seleção: pesquisas e levantamentos bibliográficos; ii) seleção parcial: eliminação dos sítios sem potencial educativo ou turístico; e iii) seleção final: com base nos trabalhos de campo. O resultado do inventário abrange a descrição e avaliação quantitativa de 25 sítios da geodiversidade, que foram quantificados por meio da plataforma GEOSSIT do Serviço Geológico do Brasil. Com base nos valores numéricos do uso potencial educativo, turístico e do risco de degradação, foram propostas medidas estruturais e atividades recreativas para estes sítios. Este trabalho permitiu avaliar a potencialidade de uso da geodiversidade como subsídio ao turismo e educação em geociências, para gerar desenvolvimento para as comunidades e um ambiente sustentável como um todo.

Palavras-chave: Estratégias de geoconservação; divulgação científica; geodiversidade; quantificação 


\section{INVENTÁRIO GEOLÓGICO DO PATRIMÔNIO CONSTRUÍDO NO LITORAL NORTE DO ESTADO DE SÃO PAULO, BRASIL}

Artigo publicado: ARRUDA, K.E.C; GARCIA, M.G.M; DEL LAMA, E.A. 2017a. Inventário Geológico do Patrimônio Construído no Litoral Norte do Estado de São Paulo, Brasil. Boletim Paranaense de Geociências, Paraná, 73 (1): 15-33. Disponível no Anexo C.

\section{RESUMO}

A geodiversidade está presente em todas as esferas do planeta, incluindo a urbana, desde a ocupação das cidades baseada na geomorfologia local, até os materiais utilizados nas construções. Este trabalho discorre sobre a relação entre o patrimônio construído e a geodiversidade encontrada nos materiais pétreos utilizados nas construções e monumentos de 4 municípios do litoral norte paulista: São Sebastião, Ilhabela, Caraguatatuba e Ubatuba. Foram analisadas em campo 31 construções na região, dentre as quais 13 receberam a denominação de Patrimônio Construído por apresentarem em sua construção materiais pétreos com aspectos geológicos relevantes, sendo elas: Casa Esperança, Sítio Histórico São Francisco, Paróquia Nossa Senhora do Amparo e Sítio Morro do Abrigo em São Sebastião; Paróquia Nossa Senhora D'Ajuda e Antigo Mercado de Escravos em Ilhabela; Igreja Matriz Santo Antônio e Relógio do Sol em Caraguatatuba; Ruínas da Lagoinha, Ruínas do Ipiranguinha, Sobradão do Porto, Monumento em Homenagem ao Caiçara e Antiga Pedreira de Itamambuca em Ubatuba. Com base no levantamento dos materiais pétreos pode-se concluir que a maioria dessas construções foram edificadas com pedra e cal conchífera, sendo as pedras obtidas principalmente da geodiversidade local, como é o caso de Ilhabela, com sienito, Ubatuba, com charnockito, São Sebastião, com gnaisse migmatítico, e Caraguatatuba, com gnaisse granítico milonítico. As formas de degradação da pedra podem ser visualizadas nessas construções, como intemperismo, eflorescência, umidade, manchamento, fraturas, aspecto brilhante e colonização biológica. A utilização desse patrimônio em termos de divulgação geocientífica mostra-se de grande eficácia para atingir a parte da população que não pode ou não possui o hábito de visitar parques e paisagens naturais, pois passam a maior parte do tempo no meio urbano, sem contato direto com a natureza.

Palavras-Chave: Patrimônio Construído; Geologia; Divulgação Geocientífica. 


\section{MAPA GEOTURÍSTICO DO LITORAL NORTE DO ESTADO DE SÃO PAULO}

O mapa geoturístico apresenta como informação principal o conjunto de sítios na região que possuem elementos da geodiversidade com potencial para divulgação turística. Para compô-lo, foram inventariados o patrimônio geológico, os sítios da geodiversidade e o patrimônio construído. Pontos representativos do patrimônio cultural estão inseridos no mapa geoturístico, como comunidades tradicionais, museus, artesanato, e outros.

Alguns pontos estratégicos foram adicionados ao mapa a fim de garantir o bem-estar dos geoturistas, como os pontos de logística representados pelas Secretarias de Turismo, sedes dos Parques Estaduais, painéis interpretativos e hospitais, e os pontos com opções alternativas para recreação.

É importante deixar claro que os seguintes mapas apresentados nesta tese tratam-se de um objeto de pesquisa e um produto destinado para fins acadêmicos, não sendo portanto um mapa geoturístico de divulgação para o público geral.

\subsection{SELEÇÃO DOS PONTOS PARA COMPOSIÇÃO DO MAPA GEOTURÍSTICO}

Para a seleção dos pontos a serem inseridos no mapa geoturístico foram realizados estudos com base no inventário e avaliação quantitativa dos geossítios e sítios da geodiversidade, inventário dos sítios do patrimônio construído e levantamento do patrimônio cultural existente no município. Os métodos de seleção utilizados são descritos nos itens a seguir.

\subsubsection{Geossítios}

Para a elaboração do mapa geoturístico foi necessário padronizar todos os geossítios da região em um único método de avaliação quantitativa para o potencial turístico. Embora os geossítios sejam predominantemente locais de alto valor científico, alguns podem apresentar concomitantemente altos valores de potencial para uso educacional e turístico.

A quantificação do potencial de uso educacional e turístico do patrimônio geológico da região foi, neste trabalho, reformulada para o mesmo método de avaliação dos sítios da geodiversidade - GEOSSIT (ROCHA et al., 2016). Neste caso, os geossítios inventariados em Prochoroff (2014), Santos (2014) e Reverte 
(2014) foram requantificados (Tabela 10) utilizando-se o novo método do GEOSSIT, que estabelece novos critérios e diferentes valores do antigo método.

Tabela 10 - Valores de potencial de uso educacional e turístico dos geossítios do litoral norte de São Paulo. Cálculo obtido pelo GEOSSIT (ROCHA et al., 2016).

\begin{tabular}{|c|c|c|}
\hline \multicolumn{3}{|c|}{ Geossítios } \\
\hline São Sebastião & Uso Educativo & Uso Turístico \\
\hline Feições de Deformação da Jureia - Engenho & 310 & 275 \\
\hline Feições de Injeção do Juquehy & 320 & 285 \\
\hline Ilhote de Camburizinho & 325 & 320 \\
\hline Praia de Boiçucanga & 320 & 285 \\
\hline Sistema de Diques da Baía do Araçá & 395 & 270 \\
\hline Costão do Centro de Biologia Marinha (CEBIMar) & 400 & 375 \\
\hline Mirante da Trilha da Praia Brava & 265 & 290 \\
\hline Milonitos da Zona de Cisalhamento Camburu & 245 & 260 \\
\hline Arquipélago de Alcatrazes & 190 & 170 \\
\hline Ilhabela & Uso educativo & Uso turístico \\
\hline Pedra do Sino & 270 & 300 \\
\hline Pico do Baepi & 250 & 215 \\
\hline Cachoeira do Gato & 210 & 200 \\
\hline Praia da Figueira - As Areias Vermelhas & 255 & 225 \\
\hline Praia das Enchovas - As Pedras Roladas & 245 & 205 \\
\hline Buraco do Cação & 210 & 200 \\
\hline Diques da Ponta da Sela & 210 & 180 \\
\hline Gabros Estratiformes & 220 & 190 \\
\hline Praia do Portinho & 250 & 220 \\
\hline Caraguatatuba & Uso educativo & Uso turístico \\
\hline Praia Brava & 256 & 240 \\
\hline Lagoa Azul & 261 & 260 \\
\hline Milonitos da Tabatinga - Ilha do Tamanduá & 226 & 210 \\
\hline Milonitos e Cataclasitos da Estrada da Petrobras & 201 & 185 \\
\hline Morro do Santo Antônio & 294 & 295 \\
\hline Geoformas de Caraguatatuba & 288 & 325 \\
\hline Registros da Catástrofe & 274 & 265 \\
\hline Ubatuba & Uso educativo & Uso turístico \\
\hline Charnockito Ubatuba & 270 & 255 \\
\hline Praia do Cedro do Sul & 215 & 195 \\
\hline Pedra do Sino de Ubatuba & 255 & 265 \\
\hline Praia da Ponta Aguda & 235 & 225 \\
\hline Monzogranito Ilha Anchieta & 215 & 195 \\
\hline Gruta que Chora & 260 & 280 \\
\hline Brecha Magmática Ilha Anchieta & 210 & 195 \\
\hline Xenólitos Mantélicos e Cones de Explosão & 240 & 235 \\
\hline Pico do Corcovado & 255 & 210 \\
\hline Pedreira Itamambuca & 290 & 265 \\
\hline
\end{tabular}

Os geossítios de Caraguatatuba (ARRUDA et al., 2015; ARRUDA et al., 2017b) foram avaliados quantitativamente através do mesmo método do GEOSSIT 
(ROCHA et al., 2016). Desta forma, o potencial de uso educacional e turístico de todos os geossítios e sítios da geodiversidade da área de estudo foram padronizados para um único método de avaliação quantitativa, o que permite com que todos os geossítios da região sejam equiparados e analisados através de um mesmo patamar.

Para fins de demonstração de todos os pontos analisados neste trabalho, foram incluídos no mapa geoturístico todos os pontos referentes aos geossítios, sítios da geodiversidade e patrimônio construído. Para expor a proposta de geoturismo com mais detalhes, este capítulo foi dividido por subitens referentes a cada município da região.

\subsubsection{Sítios da geodiversidade}

A Tabela 11 apresenta os valores gerados através da avaliação quantitativa dos sítios da geodiversidade inventariados na área de estudo. A maior parte dos sítios da geodiversidade está inserida dentro de um contexto turístico já existente. Por serem locais que apresentam beleza cênica e que já se constituem em atrativos turísticos, os sítios da geodiversidade apresentam uma maior facilidade para o diálogo com os visitantes favorecendo a implantação e divulgação do geoturismo.

\subsubsection{Sítios do patrimônio construído}

O inventário do patrimônio construído na região (ARRUDA et al., 2017a, Anexo C) resultou em 13 locais (Tabela 12) referentes a construções, ruínas e monumentos caracterizados pelo valor geológico existente nos materiais pétreos utilizados em sua construção, e inseridos no mapa geoturístico por representarem a história cultural e econômica da região constituída por materiais geológicos.

Inseridos dentro da área urbana dos municípios, os sítios do patrimônio construído são fortes elementos para a divulgação geológica, pois além do fluxo de pessoas que passam diariamente em frente a esses locais de forma rotineira, representam um patrimônio histórico e cultural que recebem constantemente a visita de turistas e estudantes.

O principal objetivo deste tipo da inclusão destes pontos é acrescentar informação geológica ao turismo já existente dentro das áreas urbanas das cidades, inserindo um novo olhar sobre o patrimônio construído, também conhecido como 
Geoturismo Urbano, e consequentemente auxiliando na educação e divulgação das geociências.

Tabela 11 - Valores de potencial de uso educacional e turístico dos sítios da geodiversidade do litoral norte de São Paulo. Cálculo obtido pelo GEOSSIT (ROCHA et al., 2016).

\begin{tabular}{|c|c|c|}
\hline \multicolumn{3}{|c|}{ Sítios da Geodiversidade } \\
\hline São Sebastião & Uso Educativo & Uso Turístico \\
\hline Dique da Cachoeira do Cambury & 210 & 225 \\
\hline Praia Brava & 230 & 210 \\
\hline Tômbolo das Calhetas & 325 & 305 \\
\hline Mirante da Barra do Una & 295 & 285 \\
\hline Intrusões Máficas de Barequeçaba & 255 & 250 \\
\hline Ilhabela & Uso Educativo & Uso Turístico \\
\hline Praia do Oscar & 265 & 270 \\
\hline Trilha da Água Branca & 235 & 240 \\
\hline Diques da Siriúba & 250 & 260 \\
\hline Cachoeira da Toca & 220 & 220 \\
\hline Lago Dourado & 225 & 240 \\
\hline Cachoeira da Laje & 205 & 220 \\
\hline Pico de São Sebastião & 260 & 245 \\
\hline Praia dos Castelhanos & 260 & 250 \\
\hline Caraguatatuba & Uso Educativo & Uso Turístico \\
\hline Foz do rio Juqueriquerê & 300 & 280 \\
\hline Pedreira Massaguaçu & 235 & 220 \\
\hline Lagoa Azul & 305 & 295 \\
\hline Gnaisse da Paróquia Santo Antônio & 255 & 270 \\
\hline Veios dobrados da Trilha do Jequitibá & 270 & 285 \\
\hline Granitos da Praia da Mococa & 265 & 270 \\
\hline Ubatuba & Uso Educativo & Uso Turístico \\
\hline Charnockito da Cachoeira do Prumurim & 290 & 315 \\
\hline Praia da Fazenda & 250 & 255 \\
\hline Mirante do Engenho & 250 & 265 \\
\hline Esporão do Puruba & 265 & 265 \\
\hline Praia da Lagoa & 280 & 275 \\
\hline Praia das Conchas & 215 & 230 \\
\hline
\end{tabular}


Tabela 12 - Sítios de patrimônio construído do litoral norte de São Paulo (ARRUDA et al., 2017a).

\begin{tabular}{|c|c|}
\hline Patrimônio Construído & Litologias dominantes \\
\hline \multicolumn{2}{|c|}{ São Sebastião } \\
\hline Casa Esperança & Gnaisse migmatítico \\
\hline Paróquia Nossa Senhora do Amparo & Gnaisse \\
\hline Sítio Morro do Abrigo & Gnaisse migmatítico \\
\hline Sítio Histórico São Francisco & Gnaisse migmatítico \\
\hline \multicolumn{2}{|l|}{ Ilhabela } \\
\hline Paróquia Nossa Senhora D’Ajuda & Sienito \\
\hline Antigo Mercado de Escravos & Sienito \\
\hline \multicolumn{2}{|c|}{ Caraguatatuba } \\
\hline Paróquia Matriz Santo Antônio & Gnaisse milonítico \\
\hline Relógio do Sol & Gnaisse milonítico \\
\hline \multicolumn{2}{|l|}{ Ubatuba } \\
\hline Ruínas da Lagoinha & Charnockito \\
\hline Ruínas do Ipiranguinha & Gnaisse \\
\hline Sobradão do Porto & Gnaisse facoidal \\
\hline Monumento em Homenagem ao Caiçara & Charnockito \\
\hline Antiga Pedreira Itamambuca & Charnockito \\
\hline
\end{tabular}

\subsubsection{Outros pontos do mapa geoturístico}

Para a elaboração do mapa geoturístico foram incluídos pontos para auxiliar o turista no planejamento de viagem e estadia nos municípios inseridos no mapa. Os pontos de apoio ao turista são representados no mapa pelas Secretarias de Turismo, hospitais, sedes do PESM e os locais onde estão instalados painéis de interpretação da geodiversidade. Os pontos de apoio são locais onde o turista pode receber informação sobre o mapa geoturístico, através de folhetos informativos e pessoal qualificado para dar esse tipo de informação. O turista poderá obter nestes locais auxílio sobre direção e rotas para se chegar a um determinado ponto do mapa, sugestões de hotéis e outras formas de alojamento, locais para desfrutar a gastronomia local, entre outros. Além dos pontos de apoio, o mapa geoturístico apresenta a localização de hospitais nos municípios, importante para oferecer uma maior segurança a agilidade em casos de acidentes.

Com o objetivo de disseminar o patrimônio cultural da região foram inseridas no mapa geoturístico as comunidades tradicionais, centros de artesanato e museus. Alguns locais que já apresentam atividades recreativas foram incluídos no mapa, como trilhas e locais para prática de esportes de aventura (praias para surfe, ciclismo e voo livre). 


\subsection{MAPA GEOTURÍSTICO E A GEODIVERSIDADE DO LITORAL NORTE DE SÃO PAULO}

Os 73 pontos referentes aos geossítios, sítios da geodiversidade e sítios do patrimônio construído do litoral norte de São Paulo estão conectados de formas distintas à geodiversidade (Mapa 1). O mapa possui 35 geossítios, que constituem os locais de maior importância geocientífica no mapa geoturístico, representando uma parte importante da história geológica da região que está diretamente relacionada à amalgamação e fragmentação do Supercontinente Gondwana.

Os sítios da geodiversidade estão representados no mapa geoturístico por 25 locais que apresentam alto potencial para uso turístico, são os locais da geodiversidade que não apresentam valor científico relevante, mas se destacam no valor de uso turístico e educativo.

Por fim, a geodiversidade também está representada nos 12 sítios do patrimônio construído presentes no mapa geoturístico. A maior parte do material pétreo utilizado na construção dos sítios do patrimônio construído são constituídos por rochas provenientes da geodiversidade local (ARRUDA et al., 2017a; ANEXO C). 
MAPA 1 - MAPA GEOLÓGICO DO LITORAL NORTE DE SÃO PAULO COM A LOCALIZAÇÃO DOS PONTOS INVENTARIADOS

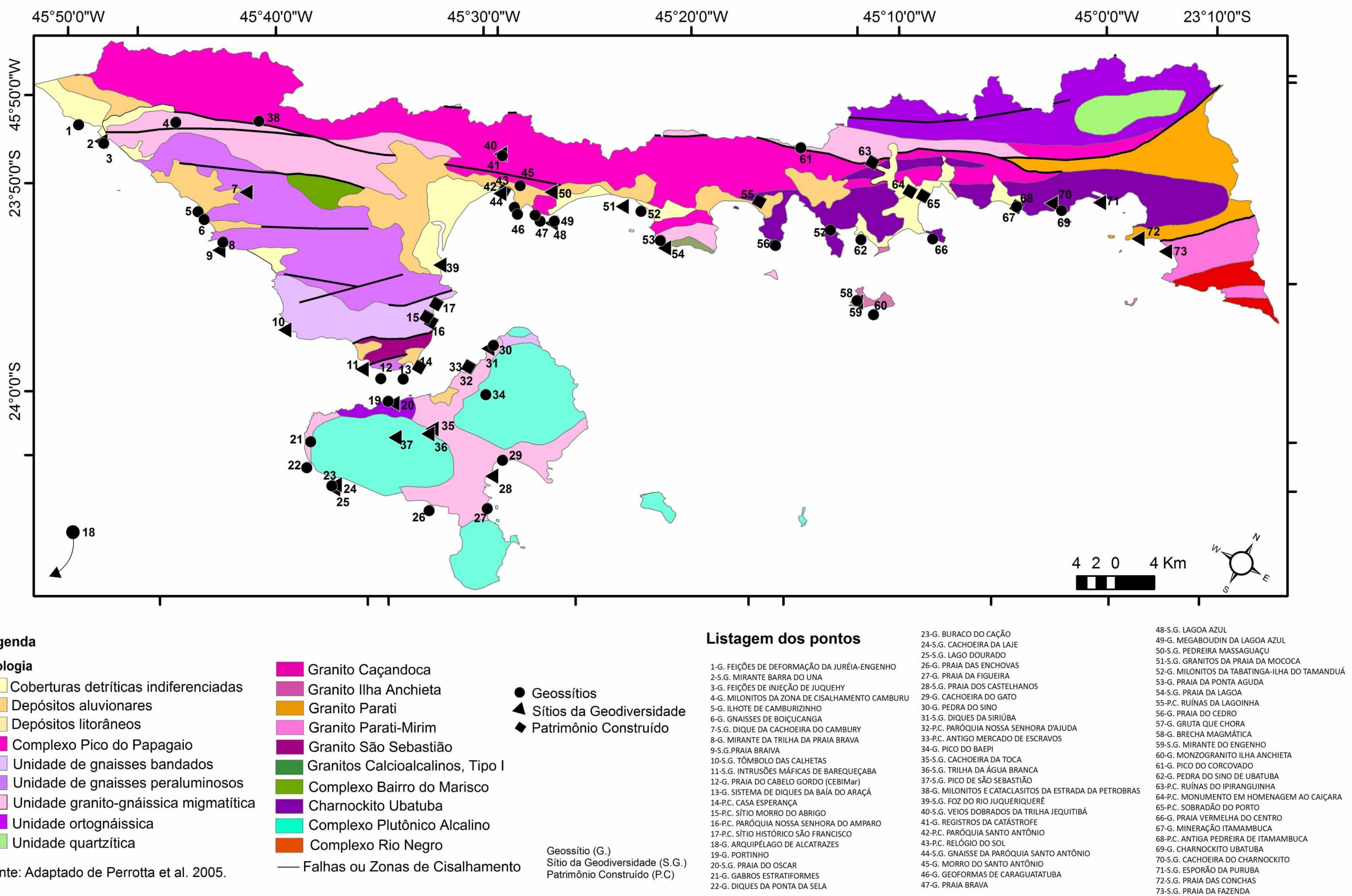




\subsection{MAPA GEOTURÍSTICO INTEGRADO}

O mapa geoturístico apresentado neste trabalho consiste em um mapa de função acadêmica, contendo os pontos que apresentaram potencial para o geoturismo neste estudo, é importante deixar claro que esses mapas não são voltados para o público geral, e sim para fins iniciais de pesquisa e de auxílio para gestão territorial.

O mapa é constituído por geossítios, sítios da geodiversidade, sítios do patrimônio construído, patrimônio cultural, pontos de apoio logístico e pontos com atividades alternativas para recreação turística. Neste trabalho, o mapa será apresentado na forma de subtitens, dividido por municípios para facilitar a descrição dos pontos no formato impresso desta tese.

\subsubsection{Mapa Geoturístico do Município de São Sebastião}

O município de São Sebastião apresenta no mapa geoturístico (Mapa 2) 9 geossítios (REVERTE, 2014), 5 sítios da geodiversidade (Anexo B), 4 patrimônios construídos (ARRUDA et al., 2017a, Anexo C), e os demais pontos relacionados à logística, patrimônio cultural e atividades recreativas, descritos abaixo.

O patrimônio construído no município é composto por 4 construções do período colonial do Brasil, sendo duas delas preservadas: Casa Esperança e Paróquia Nossa Senhora do Amparo, utilizadas até hoje. E as outras duas em estágio de ruínas: Sítio Morro do Abrigo e Sítio Histórico São Francisco, este último utilizado atualmente para fins educacionais e turísticos no município. Nestes 4 locais foram encontrados blocos de gnaisse migmatítico em seu material de construção (ARRUDA et al., 2017a), rocha comum no município.

O patrimônio cultural do município está representado no mapa por 3 pontos constituídos por duas comunidades tradicionais e um museu. As comunidades tradicionais são a Aldeia Indígena Rio Silveira, uma área de reserva indígena com 948 hectares localizado na divisa de São Sebastião e Bertioga, e a comunidade caiçara da Baía do Araçá. O terceiro ponto é o Museu de Arte Sacra, localizado no centro histórico do município.

O município de São Sebastião conta com 3 painéis interpretativos, encontrados em: Ilhote Camburizinho, abordando como se originam os diques 
e associando-os à quebra do continente; Centro de Biologia Marinha CEBIMar, abordando a formação do Supercontinente Gondwana; e Praia da Enseada, demonstrando como se formam as planícies costeiras.

Os pontos referentes à logística de auxílio ao geoturista estão representados no mapa geoturístico como painéis interpretativos, Secretaria de Turismo, Sede do PESM - Núcleo São Sebastião, hospital.

O mapa geoturístico de São Sebastião conta também com alguns pontos sugestivos de atividades alternativas, como trilhas e praia para prática de surfe.

\subsubsection{Mapa Geoturístico do Município de Ilhabela}

O mapa geoturístico do município de Ilhabela (Mapa 3) contém 9 geossítios (PROCHOROFF, 2014), 8 sítios da geodiversidade (Anexo B), 2 sítios do patrimônio construído (ARRUDA et al., 2017a, Anexo C), um sítio de patrimônio cultural e pontos referentes às trilhas no município.

O patrimônio cultural do município está representado no mapa geoturístico pelo pelourinho, localizado na Praça Coronel Júlio de Moura Negrão, local onde os escravos eram acorrentados e chicoteados como castigo e atualmente consiste em uma fonte d'água; e pela comunidade caiçara localizada na Baía de Castelhanos.

Os três painéis interpretativos no mapa geoturístico de Ilhabela estão localizados na Pedra do Sino, abordando a origem dos blocos de rochas que emitem sons no local; na Praia do Perequê, exibindo as areias de Ilhabela; e na sede do Parque Estadual de Ilhabela, abordando o vulcanismo e a origem da ilha.

Os pontos referentes à logística de apoio ao geoturista estão representados no mapa geoturístico através dos painéis interpretativos, Secretaria de Turismo, sede do Parque Estadual de Ilhabela e a localização de um hospital no município.

Ilhabela possui diversas trilhas de aventura disponíveis para 0 ecoturismo. Por conta do alto número de trilhas no município, no mapa geoturístico foram incorporadas apenas aquelas que estão interligadas de alguma forma ao acesso para os sítios da geodiversidade, sendo elas: Trilha do Pico do Baepi, Trilha da Água Branca, Trilha do Pico de São Sebastião, Trilha da Cachoeira da Laje, e a Trilha de Castelhanos. 


\subsubsection{Mapa Geoturístico do Município de Caraguatatuba}

O mapa geoturístico de Caraguatatuba (Mapa 4) contém, além de outros pontos, 7 geossítios (Anexo A), 6 sítios da geodiversidade (Anexo B) e 2 sítios do patrimônio construído (ARRUDA et al., 2017a, Anexo C).

O patrimônio cultural do município de Caraguatatuba está representado no mapa geoturístico pelo Museu de Arte e Cultura de Caraguatatuba - MACC, localizado em uma antiga escola do município e em frente à praça principal do centro de Caraguatatuba; pelo artesanato representado pelo Núcleo de Cerâmica Artesanal Terramar, que consiste no ateliê central dos artesãos e ceramistas da cidade; e por uma comunidade tradicional caiçara - Comunidade Pesqueira da Praia do Camaroeiro - localizada originalmente na Praia do Camaroeiro.

O mapa geoturístico apresenta 3 painéis interpretativos, sendo um deles um "painel síntese" contendo uma síntese da rota geoturística no litoral norte. Os outros dois painéis estão localizados no Mirante do Morro do Santo Antônio, abordando aspectos geomorfológicos da paisagem vizualizado através do mirante, e na sede do PESM - Núcleo Caraguatatuba, abordando deslizamento de terras - Como as pedras rolam - e uma breve síntese do escorregamento de massa na região em 1967.

Os pontos referentes à logística no mapa geoturístico estão representados pelos painéis de interpretação, Secretaria de Turismo, sede do PESM - Núcleo Caraguatatuba e a localização de um hospital.

No mapa geoturístico de Caraguatatuba estão presentes alguns pontos destinados à prática de esportes de aventura como trilhas no PESM, ciclismo de aventura na Estrada da Petrobras e voo livre no Morro do Santo Antônio.

\subsubsection{Mapa Geoturístico do Município de Ubatuba}

O mapa geoturístico do município de Ubatuba (Mapa 5) apresenta, entre outros pontos, 10 geossítios (SANTOS, 2015), 6 sítios da geodiversidade (Anexo B) e 5 sítios de patrimônio construído (ARRUDA et al., 2017a, Anexo C).

O patrimônio cultural de Ubatuba está representado no mapa geoturístico por 4 pontos: o Quilombo da Fazenda, comunidade tradicional quilombola localizada a menos de $2 \mathrm{~km}$ da sede do PESM - Núcleo 
Picinguaba, onde está a Casa de Farinha, um antigo engenho de milho, canade-açúcar e álcool construída no final do século XIX, atualmente em atividade com a produção de farinha de mandioca; a Aldeia Indígena Boa Vista, localizada no Bairro do Prumirim e isolada no sopé das escarpas da Serra do Mar, dista cerca de $1 \mathrm{~km}$ do sítio da geodiversidade Charnockito da Cachoeira do Prumirim; o artesanato local, representado no mapa por uma loja de artesãos que contém o artesanato de diversos artesãos da região, incluindo o artesanato indígena da Aldeia Indígena Boa Vista; e as ruínas do antigo presídio na llha Anchieta.

O mapa contém 3 painéis interpretativos, localizados na llha Anchieta, abordando a formação das rochas dessa ilha, Praia de Itamambuca, explicando como as rochas chegam à superfície e formação do Granito Verde Ubatuba, e em Picinguaba, explicando como as rochas se transformam em areias.

Os pontos referentes à logística no mapa são os painéis interpretativos, a Secretaria de Turismo, a sede do PESM - Núcleo Picinguaba e a localização de um hospital no centro da cidade.

O mapa geoturístico de Ubatuba apresenta a localização de algumas opções para passeios alternativos, como trilhas de trekking, trilha fluvial pelo manguezal do Rio Fazenda, e as trilhas subaquáticas na llha Anchieta. 


\section{$\star$ Sítios da Geodiversidade}

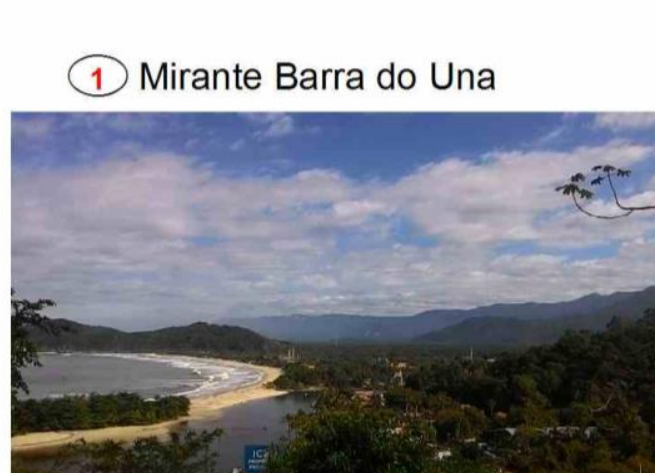

吾

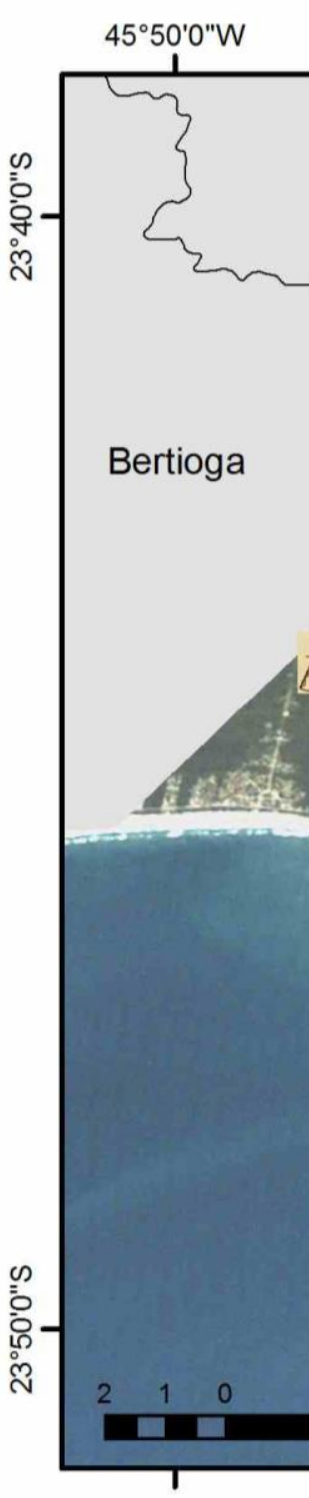

Geossítios
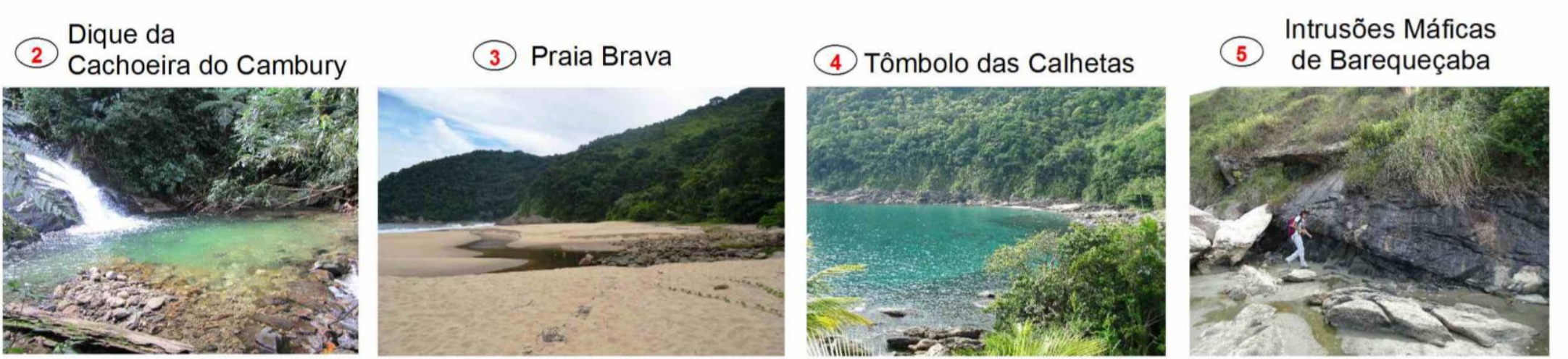

\section{Mapa Geoturistico de São Sebastião}

会 Patrimônio Construído

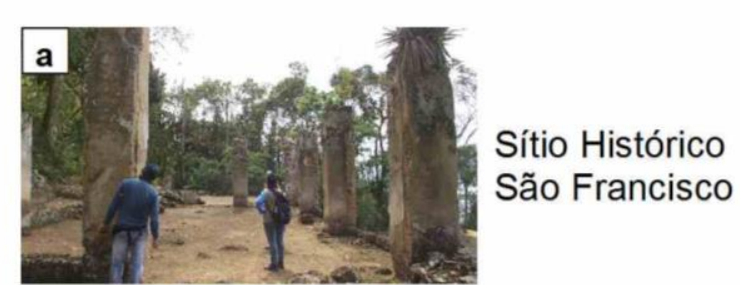

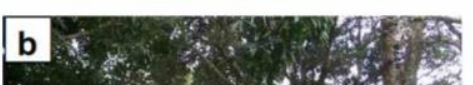

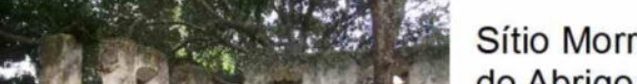
5. Lle s ab do Abrigo $\mathrm{C}^{2}+2.2 \mathrm{y}$

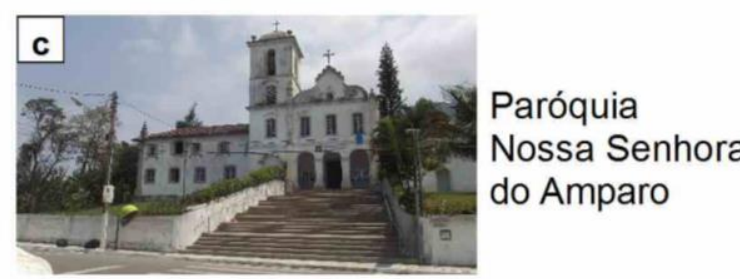

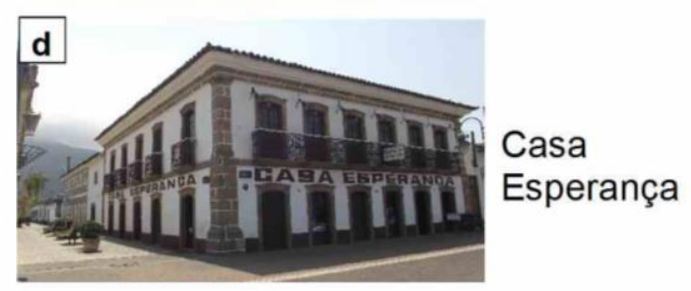

Legenda

Logistica Patrimônio Atividades i Secretaria Cultural de recreação de Turismo $\begin{aligned} & \text { Área } \\ & \text { Indigena }\end{aligned}$ Cumunidade São Trilha
Sebastiāo (7) Hospital 1 Mull Museu de

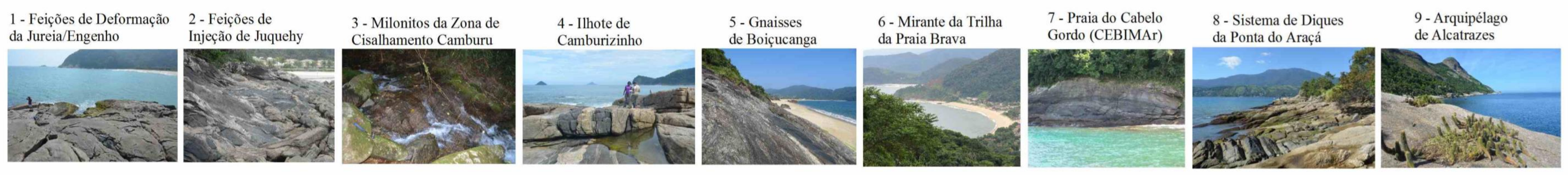

17 Painéis interpretativos - Temas 1- llhote de Camburizinho2- CEBiMar

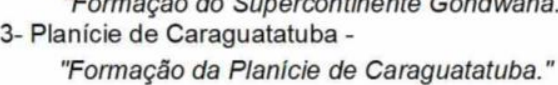


$\star$ Sítios da Geodiversidade
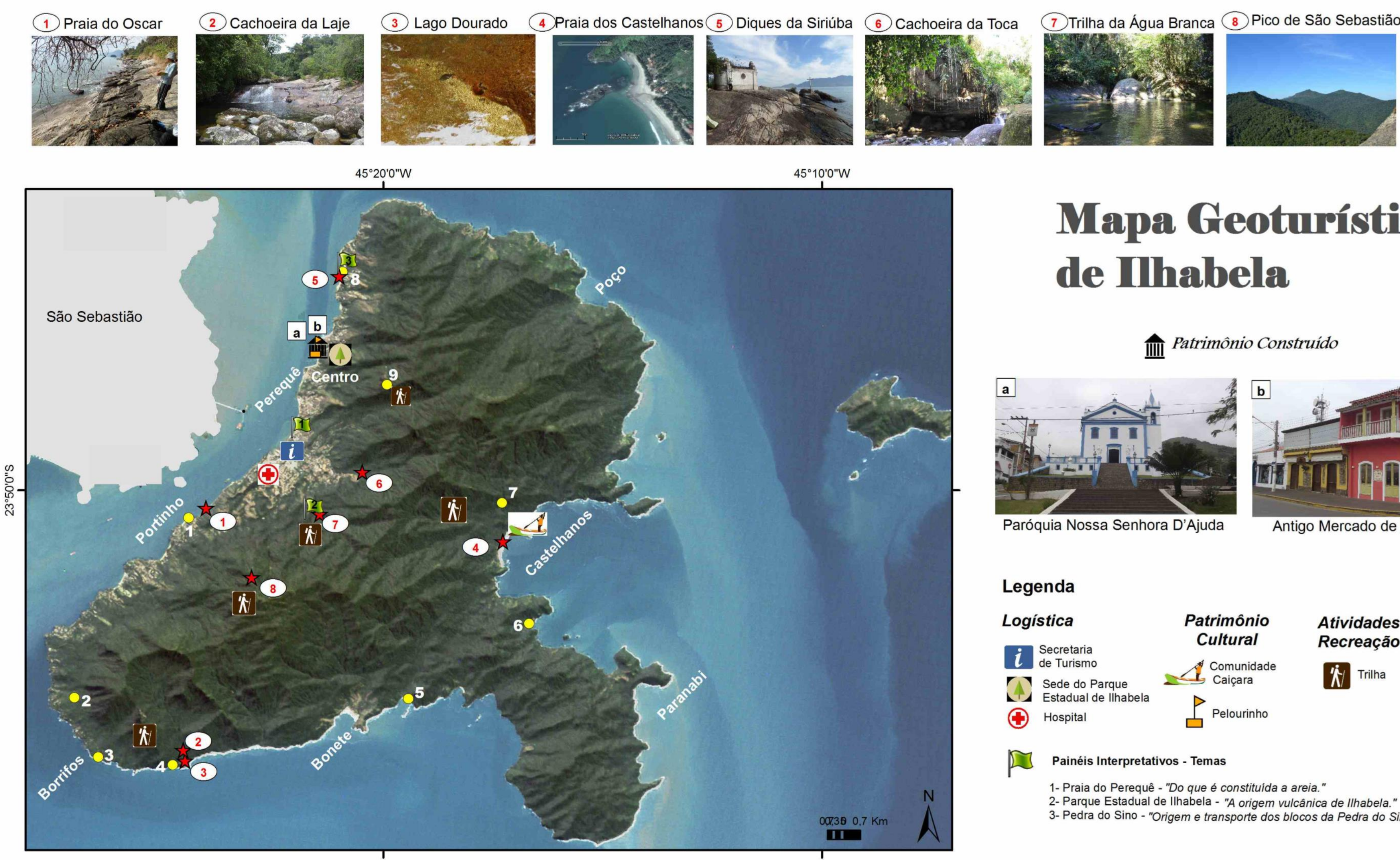

\section{Mapa Geoturístico} de Ilhabela

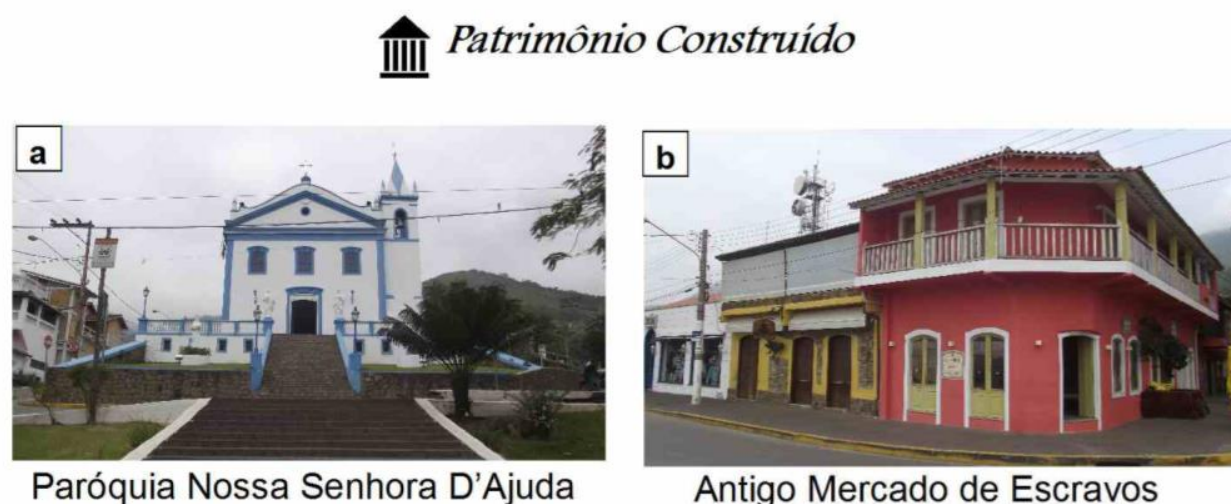

Legenda
Logística Patrimônio Atividades de
i Secretaria Cultural Recreação

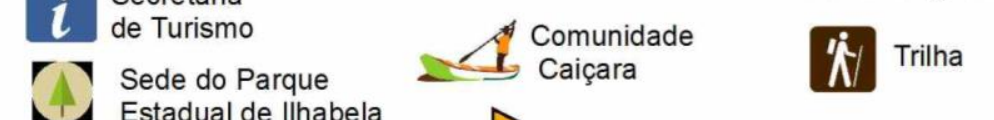

(†) Hospital dhabela Pelourinho

17 Painéis Interpretativos - Temas

1- Praia do Perequê - "Do que é constituida a areia."

2-Parque Estadual de linabela - "A origem vulcánica de llihabela."
3- Pedra do Sino - "Origem e transporte dos blocos da Pedra do Sino."

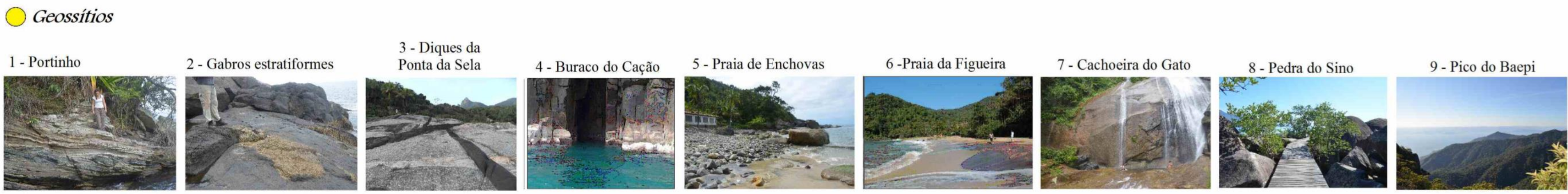



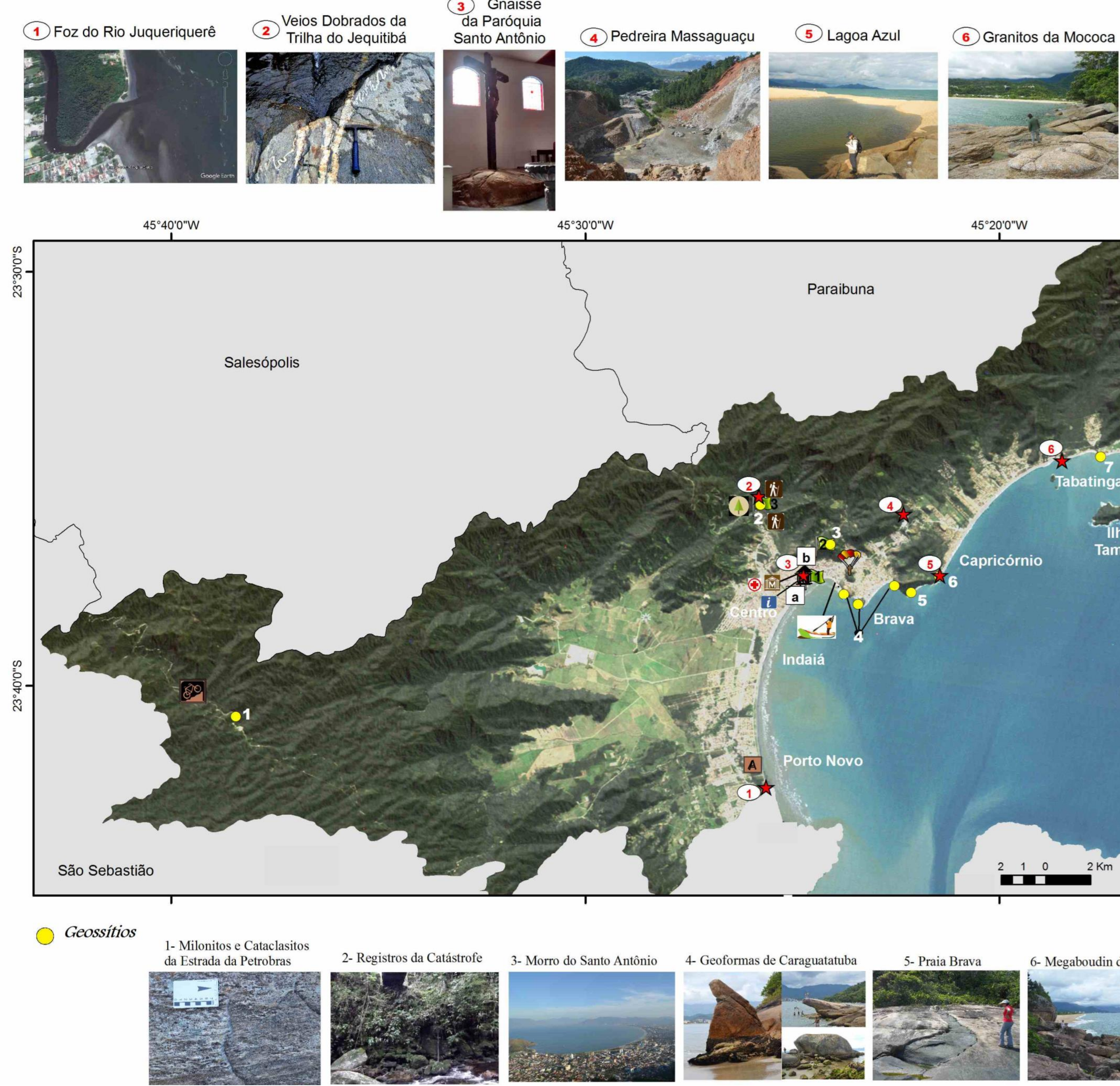

$45^{\circ} 0^{\circ} 0^{\circ} \mathrm{W}$
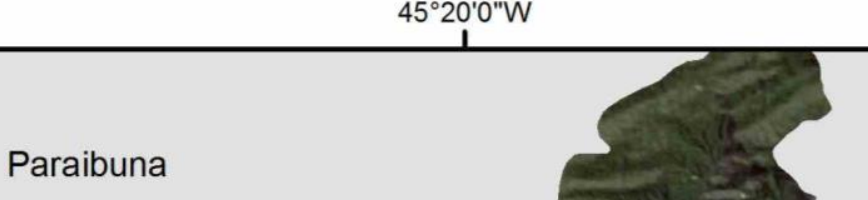

$=1-\sqrt{A}$

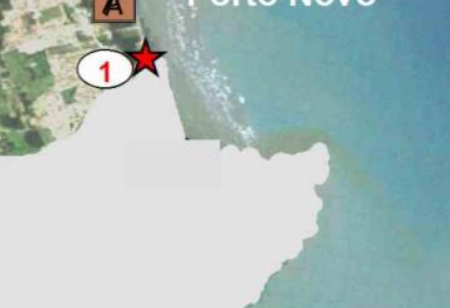

Mapa Geoturistico de Caraguatatuba
会 Patrimônio Construído

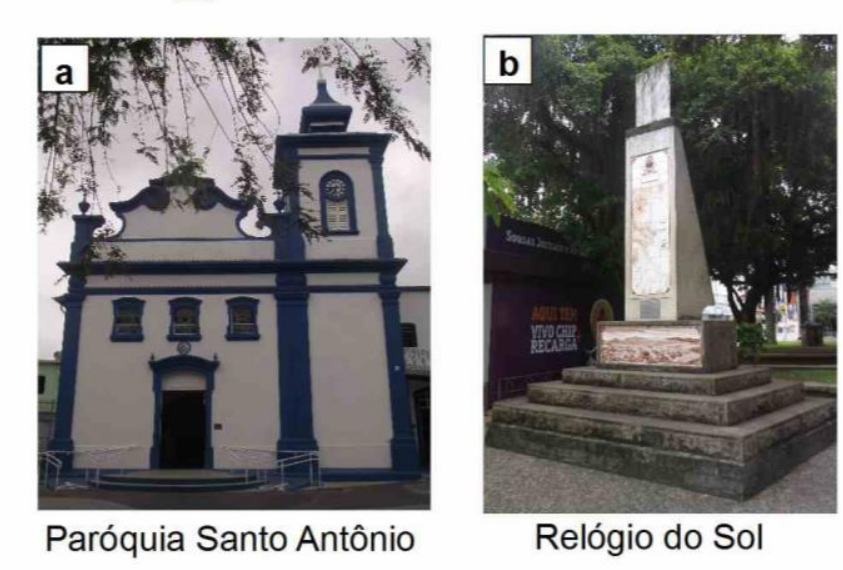

Legenda

Logística Patrimônio Atividades $i$ de Turismo

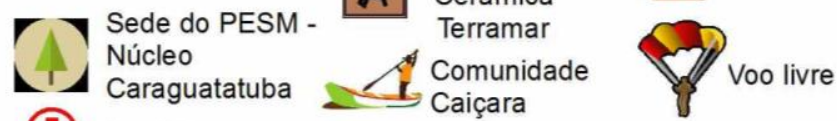
(4) Hospital

17 Painéis Interpretativos - Temas

1- Painel Sintese - "História geológica do litoral norte." 3- PESM Caraguatatuba - "Transporte de blocos pelos rios."
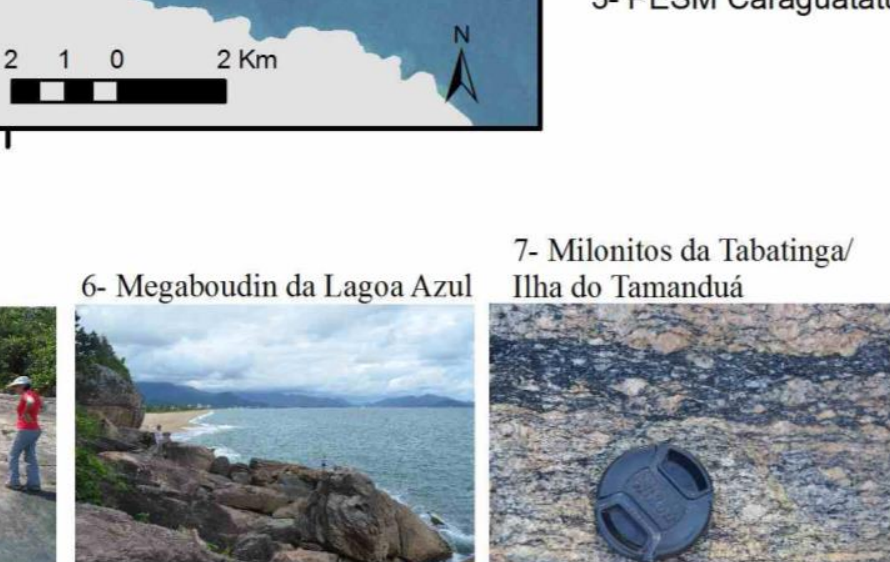
$\star$ Sítios da Geodiversidade
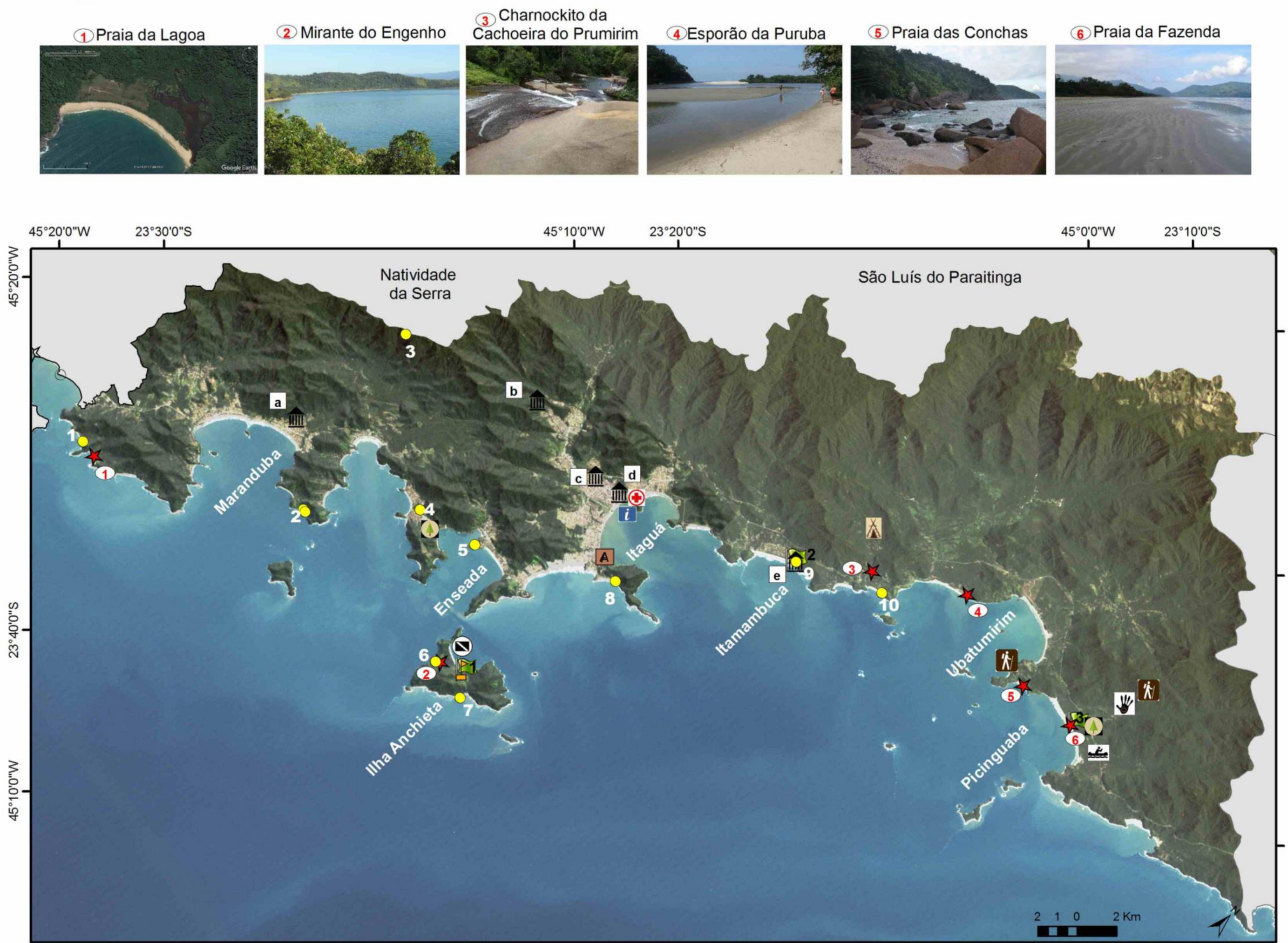

Geossitios
Mapa Geoturístico de Ubatuba

IIIII Patrimônio Construido

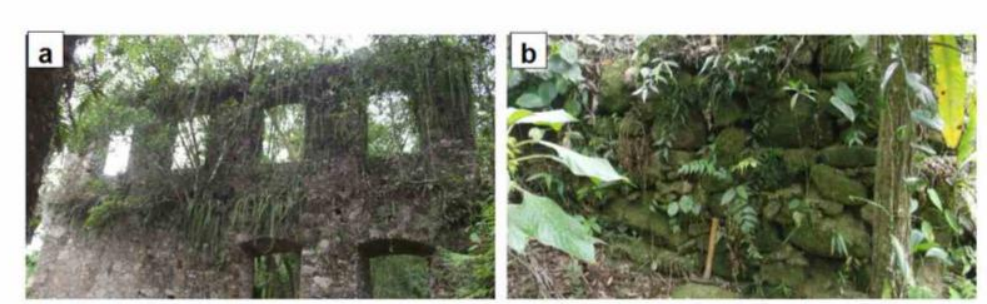

Ruinas da Lagoinha Ruínas do Ipiranguinha

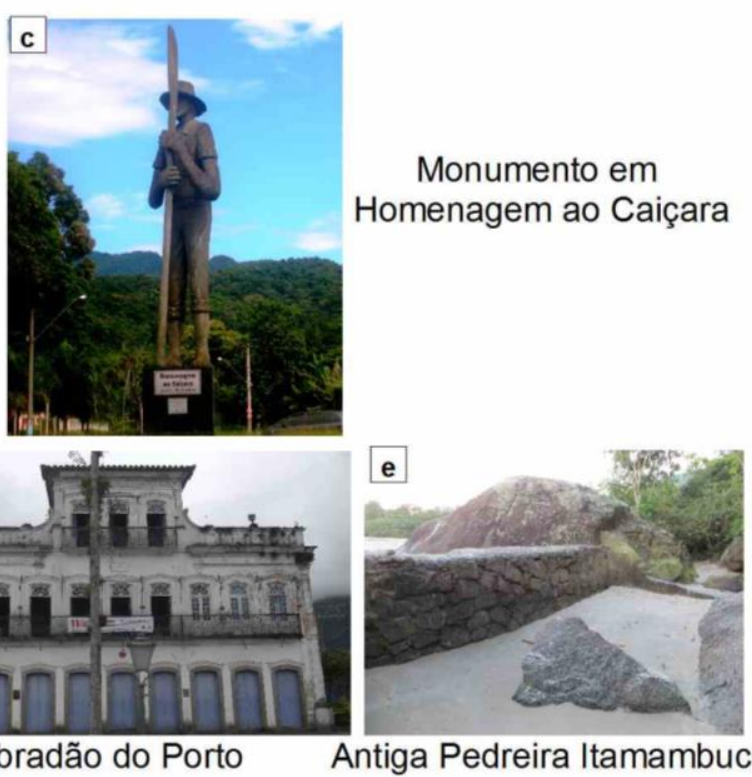

Legenda

Logistica Patrimônio Atividades

$i \begin{aligned} & \text { Secretaria } \\ & \text { de Turismo Area }\end{aligned}$

A. Sedes dos $\quad$ Parques Comunidade

(7) Hospital A Artesanato

$P_{\text {Antigo }}$ Presidio
Pas

17 Painéis Interpretativos - Temas

- llha Anchieta - "As rochas da Illa Anchieta." 2- Praia de Itamambuca - "A formaçăo do Granito Verde Ubatuba." "

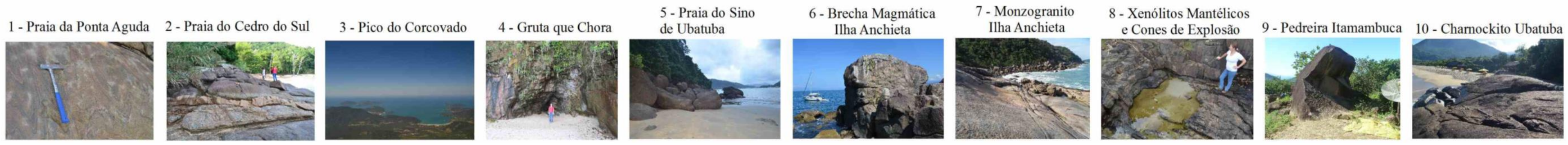




\section{DISCUSSÃO E CONCLUSÕES}

A geoconservação consiste em um novo ramo das geociências (HENRIQUES et al., 2011), inserida na geologia ambiental, trata-se de um reflexo do novo pensamento social que surgiu na segunda metade do século $X X$, quando a sociedade enfim tomou conhecimento de que não haveria condições de continuar a trajetória humana no planeta se o comportamento destrutivo e a mentalidade econômica produtivista não diminuísse. Frente a atual situação do planeta, muitas áreas das ciências voltaram-se a produção de estudos conservacionistas, devido à grande preocupação em garantir que o planeta, como um todo, possa continuar sobrevivendo em todas as esferas (biosfera, geosfera, hidrosfera, atmosfera, etc.) durante e após a trajetória da vida humana na Terra.

Diante do novo pensamento conservacionista ambiental do século XX, é preciso elaborar formas e métodos para os estudos aplicados na conservação do meio ambiente. A geoconservação caracteriza-se por ser o ramo das geociências responsável por garantir a conservação da geosfera. Shaples (2002) definiu o termo geoconservação como a preservação da diversidade natural de significativos processos e aspectos geológicos, geomorfológicos e de solo, mantendo sua evolução natural.

O primeiro passo para iniciar as estratégias de geoconservação é o levantamento de tudo aquilo que está ameaçado ou que mereça ser conservado com prioridade dentro da geodiversidade.

O levantamento e inventário dos locais mais importantes da geodiversidade do litoral norte de São Paulo foram realizados nesta tese e nos trabalhos de Prochoroff (2014), Santos (2014) e Reverte (2014). O resultado obtido a partir desses estudos permitiu a elaboração do mapa geoturístico da região para fins exclusivos de auxílio à gestão territorial, não sendo um mapa de divulgação final para o público.

A utilização do geoturismo como estratégia de geoconservação foi apresentada em Brilha (2005), onde o autor sugere os geossítios menos vulneráreis como os melhores locais a serem inseridos no geoturismo, enquanto a utilização de geossítios vulneráveis ficaria restrita para o uso apenas após estabelecidas as condições necessárias para manter o local 
protegido, com o objetivo de evitar possíveis degradações através da atividade geoturística.

Para gerar o mapa geoturístico do litoral norte, foi preciso pensar alguns aspectos sobre possibilidades de utilização e de desenvolvimento socioeconômico e ambiental do território. Segundo os aspectos do geoturismo descritos em Dowling (2009), são necessárias a criação de produtos autênticos do geoturismo, a conservação dos sítios, a divulgação da geodiversidade, a participação da comunidade e parcerias com instituições interessadas.

A partir do mapa geoturístico foi possível propor alguns aspectos de gestão, pensando nos atores sociais da região, infraestruturas para 0 geoturismo, divulgação geocientífica e geração de produtos. O atual mapa consiste em uma ferramenta para o trade turístico, auxiliando no inventário turístico dos municípios, ao definir com base na metodologia apresentada quais áreas seriam prioritárias. Os itens a seguir discutem os resultados e sugerem como o mapa geoturístico pode ser utilizado pela sociedade.

\subsection{INTERPRETAÇÃO DA GEODIVERSIDADE ATRAVÉS DO GEOTURISMO}

Para entender e trabalhar o espaço geográfico é necessário conhecer a história e a cultura da sociedade pertencente a área em estudo. O patrimônio natural e o patrimônio cultural estão diretamente interligados. A partir do momento que conhecemos a história e entendemos a cultura de um povo, podemos enfim compreender sua forma de pensar e, no caso deste trabalho, de interpretar a paisagem geológica.

A paisagem consiste no recorte geográfico a partir do olhar do observador, sendo um elemento inteiramente individual e subjetivo, baseado nas experiências vividas e conhecimentos adquiridos por cada indivíduo. Para fazer com que o observador consiga, ao olhar a paisagem, interpretar a geodiversidade ali existente é necessário um conhecimento prévio relacionado às geociências e, para isso, é preciso um amplo e lento trabalho em conjunto com todas as esferas sociais, a começar pelo sistema educacional de base.

Elaborar uma proposta geoturística para uma região consiste em reconhecer o indivíduo como elemento central do estudo, no qual deve ser 
considerado todo o contexto humanístico e social. Trabalhar formas de interpretação da paisagem é trabalhar com a subjetividade, levar ao indivíduo o sentido de identificar e pertencer àquele meio.

Melendez et al. (2011) atentam para as três maiores dificuldades dos turistas no momento de interpretar o ambiente geológico, que são: a geocronologia, a paleogeografia ou paleoambiente; e o conceito de framework, isto ocorre devido à abstração exigida na hora de pensar o tempo geológico, a dificuldade real de contabilizar um número nunca antes visto. Por isso, é necessário pensar a linguagem que será repassada para pessoas que não possuem aprofundamento científico na área das geociências. Os autores supracitados deixam claro a diferença entre as linguagens para uso científico e para o uso turístico (Figura 4), que deve ser fornecida da forma mais sutil possível, com o mínimo de termos técnicos.

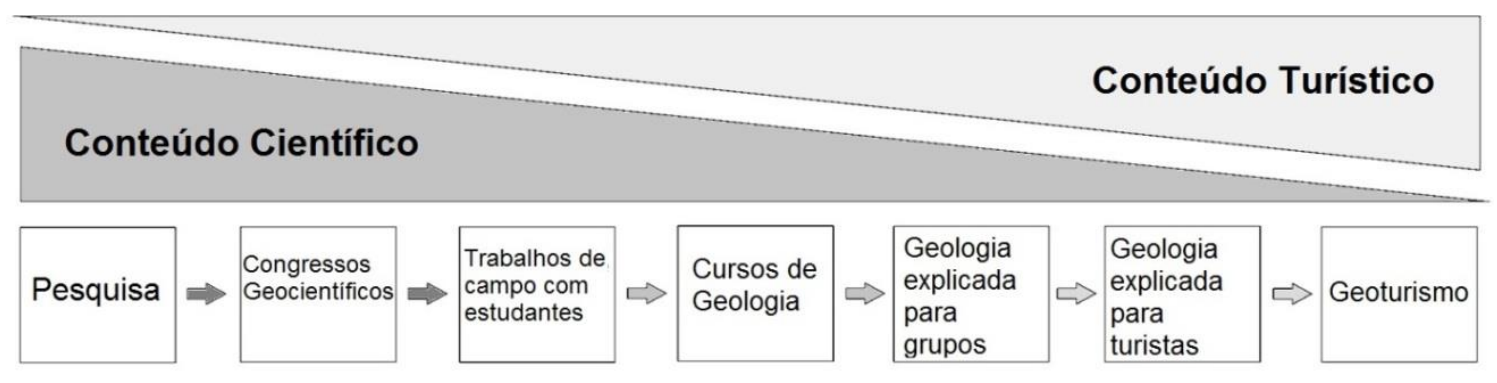

Figura 4 - Esquema diagrama sobre o conteúdo científico e o conteúdo turístico. Fonte: Melendez et al. (2011)

\subsection{SERVIÇOS E BENEFÍCIOS SOCIOECONÔMICOS ASSOCIADOS AO GEOTURISMO}

O turismo responde por grande parte da economia e geração de empregos no país (IBGE, 2017). Como uma vertente do turismo, o geoturismo entra com o objetivo não só de auxiliar o bem-estar econômico dos habitantes locais, mas também o bem-estar social, sendo um investimento em cultura e educação.

Deste modo, o geoturismo além de fortalecer o turismo tradicional gera uma demanda por guia de geoturismo - guias de turismo especializados em geociências, agências de turismo especializadas em passeios e rotas geoturísticas e geoprodutos. Este tipo de abordagem econômica gerada pelo geoturismo pode ser observada em diversas partes do mundo. 
A Figura 5 mostra algumas possibilidades de exploração do geoturismo, como a apropriação de valores da geodiversidade para atrair clientes em estabelecimentos, como é o caso do Georestaurante Petiscos e Granitos, no Geoparque Naturtejo em Portugal (Figura 5a), que se utilizou da presença do afloramento granítico no entorno do restaurante para fornecer ao turista uma experiência única. A demanda por guias de turismo especializados em geoturismo, com capacitação para repassar as informações acerca da geodiversidade para os visitantes em uma linguagem apropriada (Figura 5b). E a oferta de geoprodutos (Figuras $5 c$ e $5 d$ ), que podem ser advindos do artesanato local inspirado ou não na geodiversidade, surgido como consequência do novo fluxo de turistas em uma região específica onde está inserido o geoturismo.
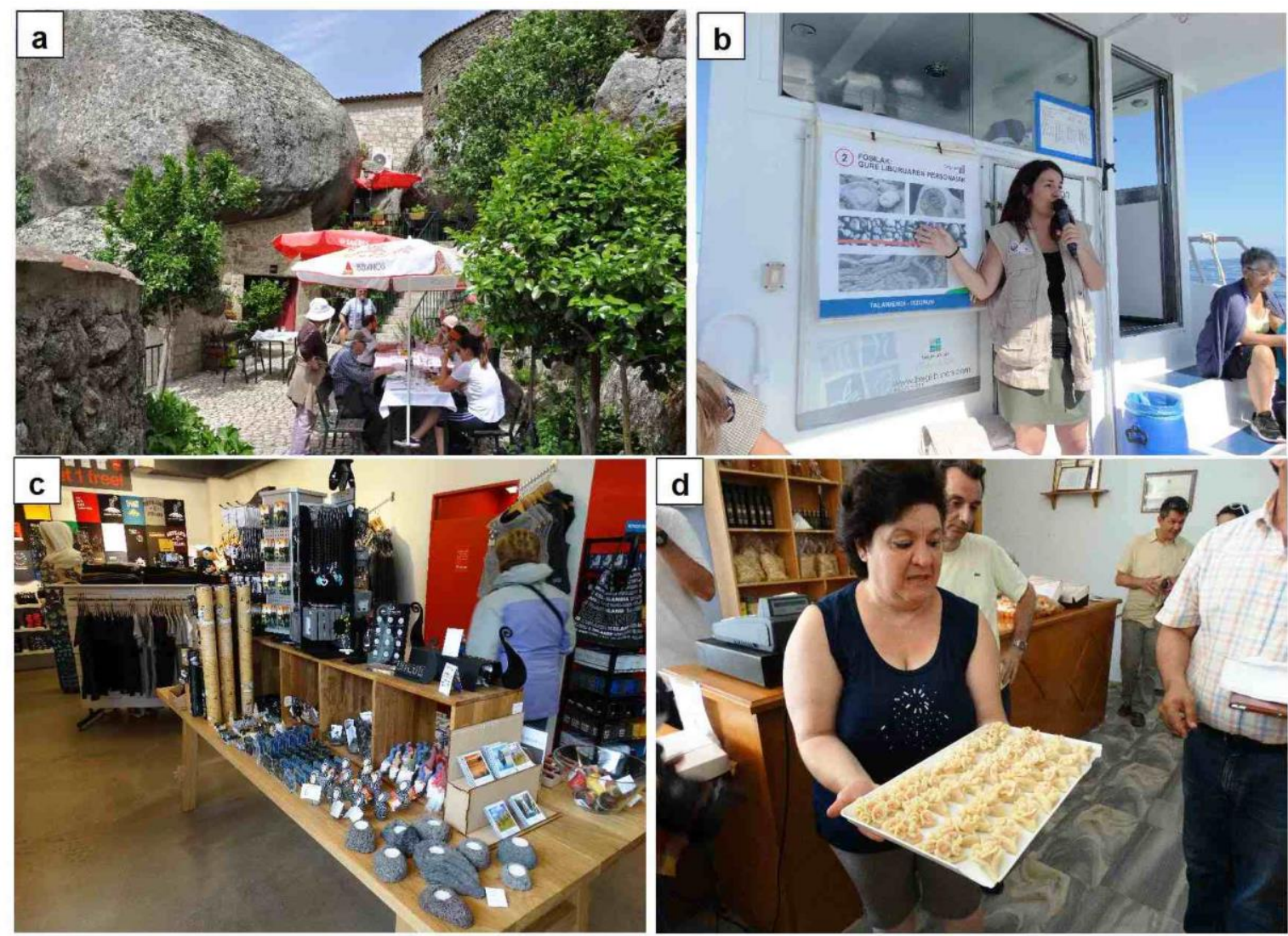

Figura 5 - Exemplos de geração de empregos e geoprodutos gerados através do geoturismo. a - Georestaurante Petiscos e Granitos, no Geoparque Naturtejo em Portugal, localizado entre blocos e afloramentes de granitos (Foto: Thais Guimarães); b - estudante de geologia realizando estágio como guía geoturística no Geoparque da Costa Basca, País Basco; c - loja de souvenirs na Islândia com diversas peças da geodiversidade à venda, como basaltos e poeira vulcânica; $d$ - confeiteira de uma comunidade de mulheres em Lesbos, Grécia, apresentando seus produtos para os visitantes do Geoparque da Floresta Petrificada em Lesbos. 


\subsection{ESTRATÉGIAS DE GEOCONSERVAÇÃO}

Como já foi visto, o próprio mapa geoturístico consiste em uma estratégia de geoconservação, entretanto a utilização de infraestruturas para auxiliar na interpretação da geodiversidade é essencial quando se aborda 0 geoturismo. Um exemplo de abordagem para a interpretação da geodiversidade é a instalação de painéis interpretativos. A confecção desses painéis demanda estudo em conjunto com pesquisadores, designers e educadores, de forma a oferecer uma informação geológica ao visitante através de uma linguagem acessível para todos os tipos de público, mas que também forneçam informações atraentes para os geoturistas empenhados em aprender sobre a história geológica do local.

Os painéis são o meio de interpretação mais comum em parques ambientais, pela praticidade da informação oferecidade in loco aos visitantes. A aplicação de painéis requer cuidados com a manutenção, pois a escolha de materiais frágeis a intempéries pode acabar prejudicando a vizualização das informações. Nos exemplos da Figura 6 é possível observar alguns tipos de painéis existentes, como os que possuem cobertura solar (Figura 6a e 6b) protegendo o painel da ação do sol e aumentando a vida útil do material. Painéis que não possuem proteção (Figura $6 \mathrm{c}$ ) normalmente acabem por ter 0 material danificado e parte das informações apagadas do painel, necessitando manutenção constante. No Parque do Varvito em São Paulo, é possível obeservar painéis em ótimas condições de leitura pela manutenção constante realizada pelo parque (Figura $6 \mathrm{~d}$ ).

Embora existam outras ferramentas de auxílio para a interpretação da geodiversidade, como livros e folhetos, por exemplo, a estrutura mais eficiente para introduzir conceitos em geociências e demonstrar a geodiversidade local para a população são os centros de interpretação. Diferentemente dos painéis, que devem conter informações curtas, rápidas e objetivas, os centros de interpretação devem apresentar a geodiversidade para o visitante de forma interativa e no conforto de um ambiente que forneça ao visitante infraestrutura básica de apoio para que ele possa explorar o espaço e absorver as informações mais tranquilamente. 

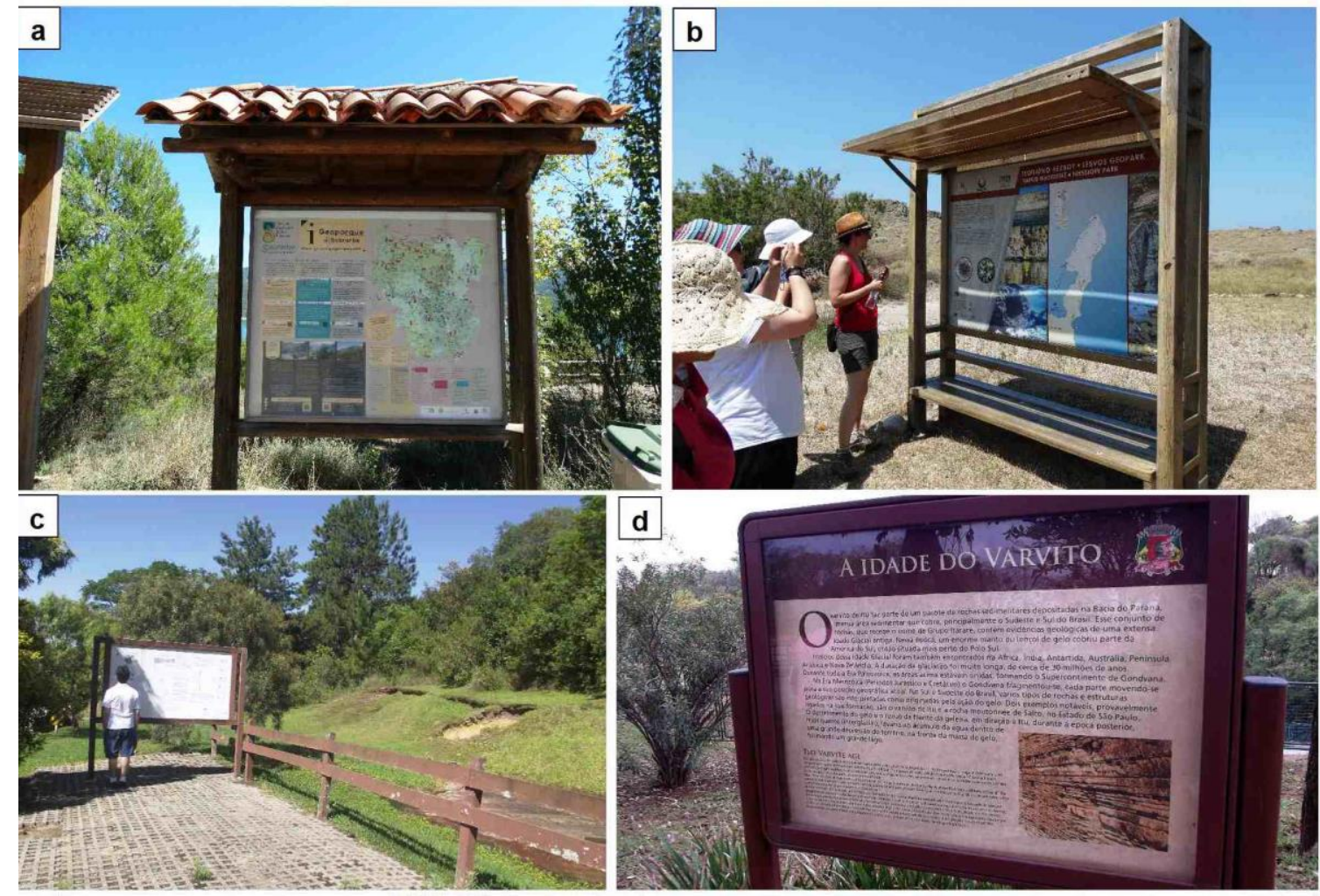

Figura 6 - Painéis de interpretação da geodiversidade. a - Geoparque de Sobrarbe, Espanha; b - Geoparque da Floresta Petrificada em Lesbos, Grécia; c - Colônia Witmarsum, Paraná; d - Parque do Varvito, São Paulo.

$\mathrm{Na}$ figura 7 são apresentados alguns exemplos de centros de interpretação que fornecem informações geológicas aos visitantes através de métodos interativos, como o centro de interpretação do Geoparque de Sobrarbe na Espanha, com algumas amostras de rochas disponibilizadas em mesas para que o visitante possa tocá-las (Figura 7a), e o centro de interpretação do Geoparque da Costa Basca no País Basco, com variedades de peças em exposição onde o visitante pode interagir (Figura 7b). O centro de interpretação do Geoparque de Lesbos na Grécia (Figura 7c) apresenta diversas amostras de rochas e fósseis no seu acervo, com a possibilidade de salas multisensitivas, como a sala que demonstra aos visitantes a sensação causada pelos terremotos através de tremores no piso, levando o visitante à uma sensação empírica de como seria conviver em locais onde esses tremores são frequentes. Por fim, existem os centros de interpretação com oferta de informações geológicas no formato digital, interagindo com os visitantes através de telas táteis e vídeos explicativos, como é o caso do Geyser Center na Islândia (Figura 7d). 

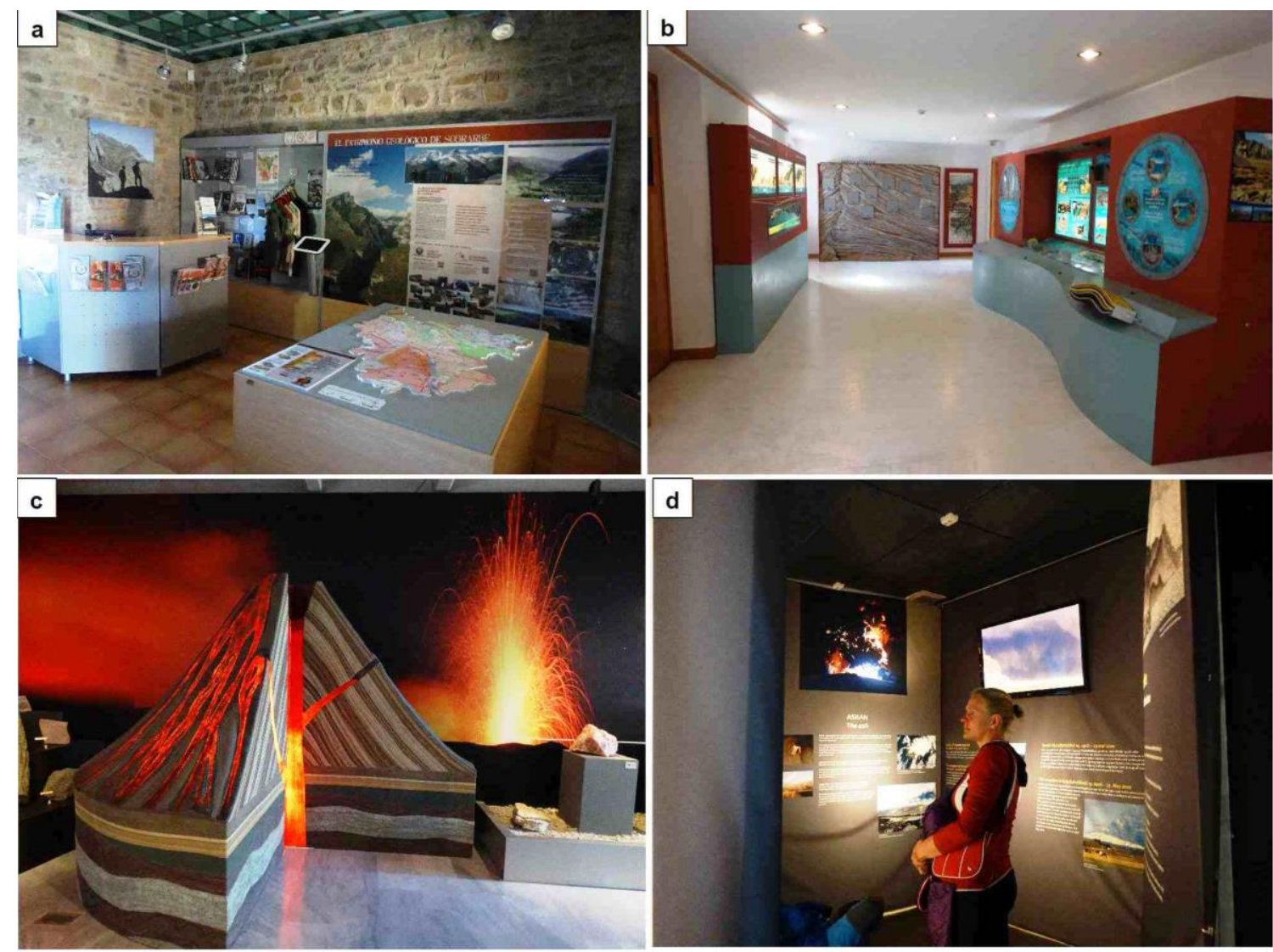

Figura 7 - Centros de interpretação da geodiversidade. a - Geoparque de Sobrarbe, Espanha; b - Geoparque da Costa Basca, País Basco; c - Geoparque de Lesbos, Grécia; d - Geyser Center, Islândia.

\subsection{AÇÕES DE GEOCONSERVAÇÃo NO LITORAL NORTE DE SÃO PAULO}

A região do litoral norte de São Paulo já vem sendo objeto de ações em geoconservação (GARCIA et al., 2011; GARCIA, 2012; GARCIA et al., 2013; GARCIA et al., 2016; GARCIA et al., 2017; MAZZUCATO, 2017) (Figura 8). O reconhecimento da importância de sua geodiversidade favoreceu 0 investimento em pesquisas que desenvolvam estratégias para a geoconservação na região. Algumas ações principais estão descritas em Garcia et al. (2017), abaixo relacionadas:
a) relação entre o patrimônio natural e cultural;
b) implementação de painéis interpretativos;
c) aprendizagem social;
d) confeccção de livros educativos;
e) interpretação geológica de trilhas;
f) cursos de geociências para guias de turismo e monitores ambientais. 

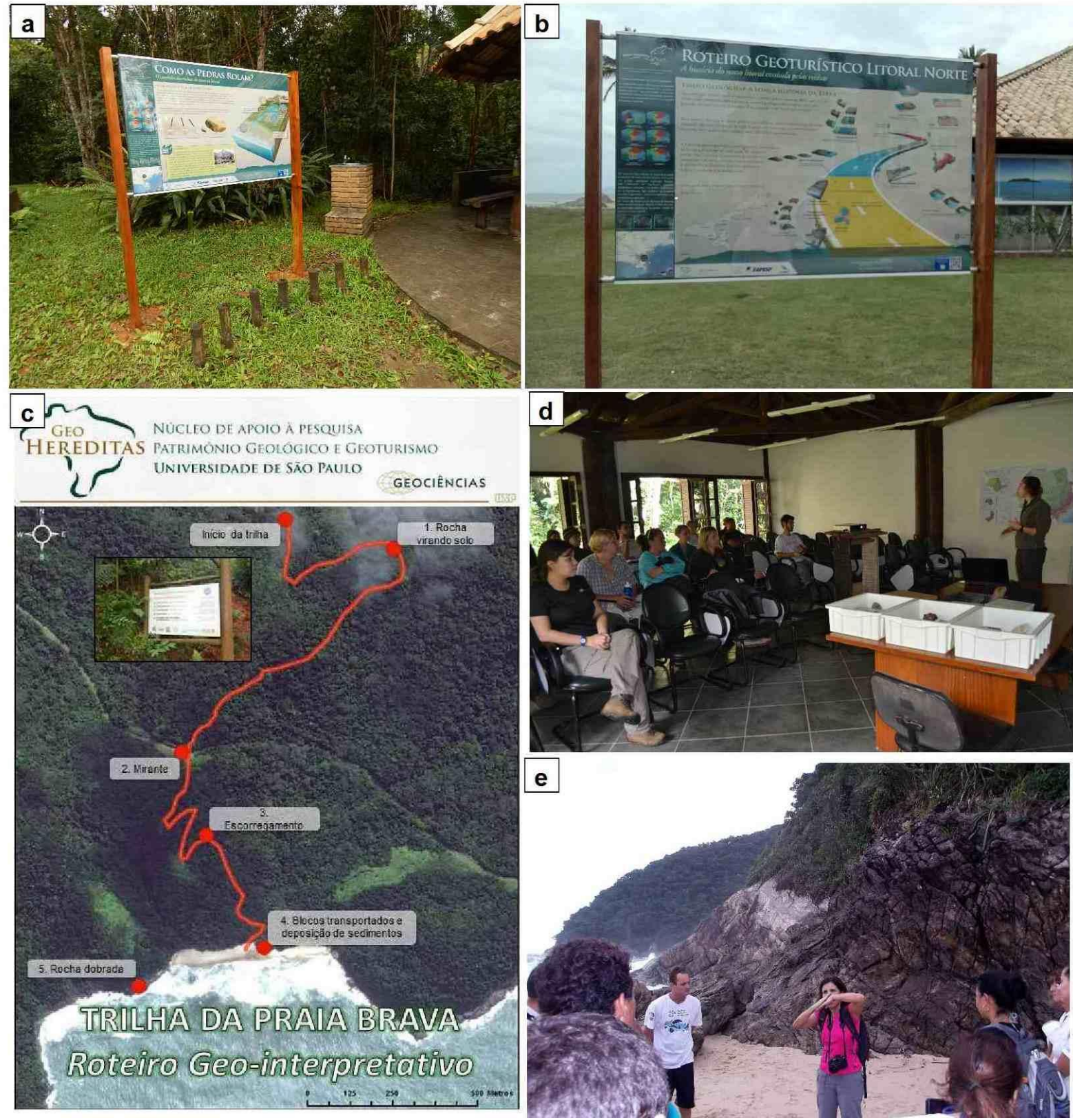

Figura 8 - Exemplos de ações de geoconservação no litoral norte de São Paulo. a painel interpretativo sobre a geodiversidade local, localizado na Sede do PESM Núcleo Caraguatatuba; $b$ - painel interpretativo síntese do roteiro geoturístico do litoral norte de São Paulo, em Caraguatatuba; c - roteiro geointerpretativo de trilhas, Trilha da Praia Brava, São Sebastião; d - curso de geociências para monitores ambientais no PESM; e - aula de campo para os monitores do PESM, em São Sebastião.

A relação entre o patrimônio natural e cultural é um dos resultados deste trabalho e consiste no inventário dos sítios do patrimônio construído, uma estratégia de geoconservação que incorpora as áreas urbanas no contexto geoturístico com a utilização do material pétreo em construções e ruínas já conhecidas e familizaridas pelos habitantes locais para demonstrar e divulgar a geodiversidade da região. 
Algumas dessas ações de geoconservação já apresentam uma resposta da sociedade, como por exemplo, os painéis interpretativos sendo atualmente utilizados por professores de escolas que levam seus alunos até o local da instalação do painel para explicar o que está descrito. Outro exemplo é o resultado dos cursos de geociências ministrados para monitores ambientais e guias de turismo, onde já é possível observar alguns desses guias e monitores explicando aspectos da geodiversidade para turistas durante as trilhas.

\subsection{ELABORAÇÃO DO MAPA GEOTURÍSTICO}

A elaboração do mapa geoturístico seguiu uma série de etapas (Figura 9), a começar pela escolha do recorte geográfico que deve ser equivalente aos limites territoriais existentes na área de estudo. A importância em estabelecer os limites territoriais está em facilitar a futura gestão do geoturismo na área.

Realizado o recorte geográfico, passa-se para a segunda etapa, representada pelo levantamento de dados geológicos, sociais e culturais da área de estudo para a pré-seleção de possíveis locais a serem inventariados. A seleção do patrimônio geológico e dos sítios da geodiversidade exige inventário e avaliação quantitativa. A seleção do patrimônio construído exige um estudo detalhado dos materiais pétreos e consolidantes utilizados nas construções.

A partir dos resultados obtidos nas etapas anteriores, os locais estudados devem ser adaptados, quando necessário, para a implantação do geoturismo, como infraestruturas de geoconservação e de interpretação geológica. Devem ser inseridos pontos representativos do patrimônio cultural local, e pontos de apoio para auxílio logístico ao geoturista. Por fim, o mapa geoturístico é gerado pelo limite geográfico da área de estudo contendo os pontos referentes ao patrimônio geológico, sítios da geodiversidade, sítios do patrimônio construído, patrimônio cultural e pontos de apoio logístico. Em alguns casos, são inseridos pontos alternativos para recreação turística.

O mapa geoturístico resultante deve ser apresentado às autoridades locais e à comunidade, a fim de realizar parcerias e firmar um gestão competente que pode ser através de iniciativas governamentais e/ou privadas, em conjunto com a sociedade. 


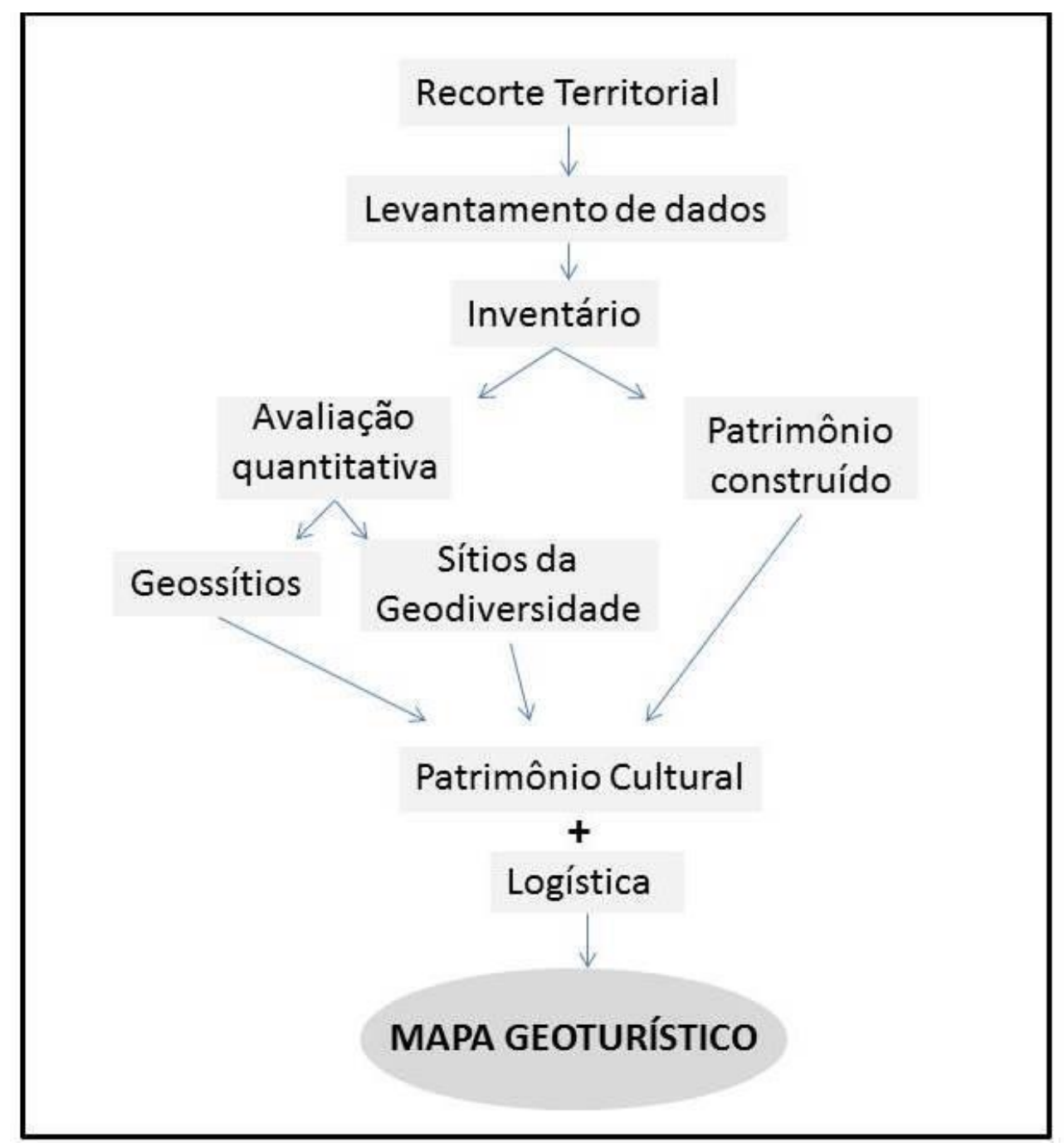

Figura 9 - Fluxograma das etapas para a elaboração do mapa geoturístico.

\subsection{POTENCIAL GEOTURÍSTICO DOS MUNICÍPIOS}

Nos seguintes itens serão apresentados e discutidos o potencial geoturístico existente nos municípios do litoral norte de São Paulo.

\subsubsection{Geoturismo em São Sebastião}

O município de São Sebastião teve seu patrimônio geológico inventariado e quantificado em Reverte (2014), onde são descritos os 9 geossítios utilizados neste trabalho. A autora avaliou o potencial didático, turístico e científico de todos os geossítios, no qual dois deles não apresentaram potencial turístico: Sistema de Diques da Ponta do Araçá e o Arquipélago de Alcatrazes. 
O Geossítio Sistema de Diques da Ponta do Araçá apresenta-se atualmente sob ameaça de degradação antrópica pela proximidade ao centro urbano e ao Porto Marítimo do município. Segundo Reverte (2014), essas ameaças podem gerar danos irreversíveis ao local, a autora descreve também a dificuldade de observação do geossítio relacionado às variações da maré que possibilita a visitação apenas na maré baixa. Apesar dessas ameaças, 0 geossítio está inserido no contexto cultural do município, onde reside uma comunidade caiçara que utiliza o ambiente em seu entorno para manter suas atividades de subsistência.

O Geossítio Arquipélago de Alcatrazes, localizado há $36 \mathrm{~km}$ de distância do Porto de São Sebastião, não apresentou potencial turístico na avaliação quantitativa em Reverte (2014) por não permirtir o acesso de turistas na ilha. Em 2016, o arquipélago foi oficializado como Refúgio de Vida Silvestre, permitindo sua abertura à visitação e mergulho, porém até o atual momento desta tese as atividades turísticas no arquipélago ainda não foram liberadas. Os demais geossítios de São Sebastião apresentaram potencial turístico, assim como os sítios da geodiversidade.

O patrimônio cultural do município inclui uma área de reserva indígena A Aldeia Indígena Rio Silveira (Figura 10a), com 948 hectares localizado na divisa de São Sebastião e Bertioga e uma comunidade caiçara na Baía do Araçá.

O município está inserido na rota de pedestre "Passos dos Jesuítas", organizada pela Secretaria de Turismo do Estado de São Paulo, que reproduz os passos da presença jesuítica na região no Século XVI (Figura 10b), passando por 13 municípios e sugere locais para visitação durante a passagem do pedestre. Um dos pontos de visitação sugeridos pela rota em São Sebastião é o patrimônio construído do Sítio Histórico São Francisco.

O Centro histórico de São Sebastião representa o principal ponto turístico do município com diversas opções de restaurantes oferecendo gastronomia local (Figura 10c), o Museu de Arte Sacra (Figura 10d) e as ruas e construções preservando o aspecto colonial da cidade, em algumas delas pode-se ver preservadas partes da construção original (Figuras 10e e 10f). 

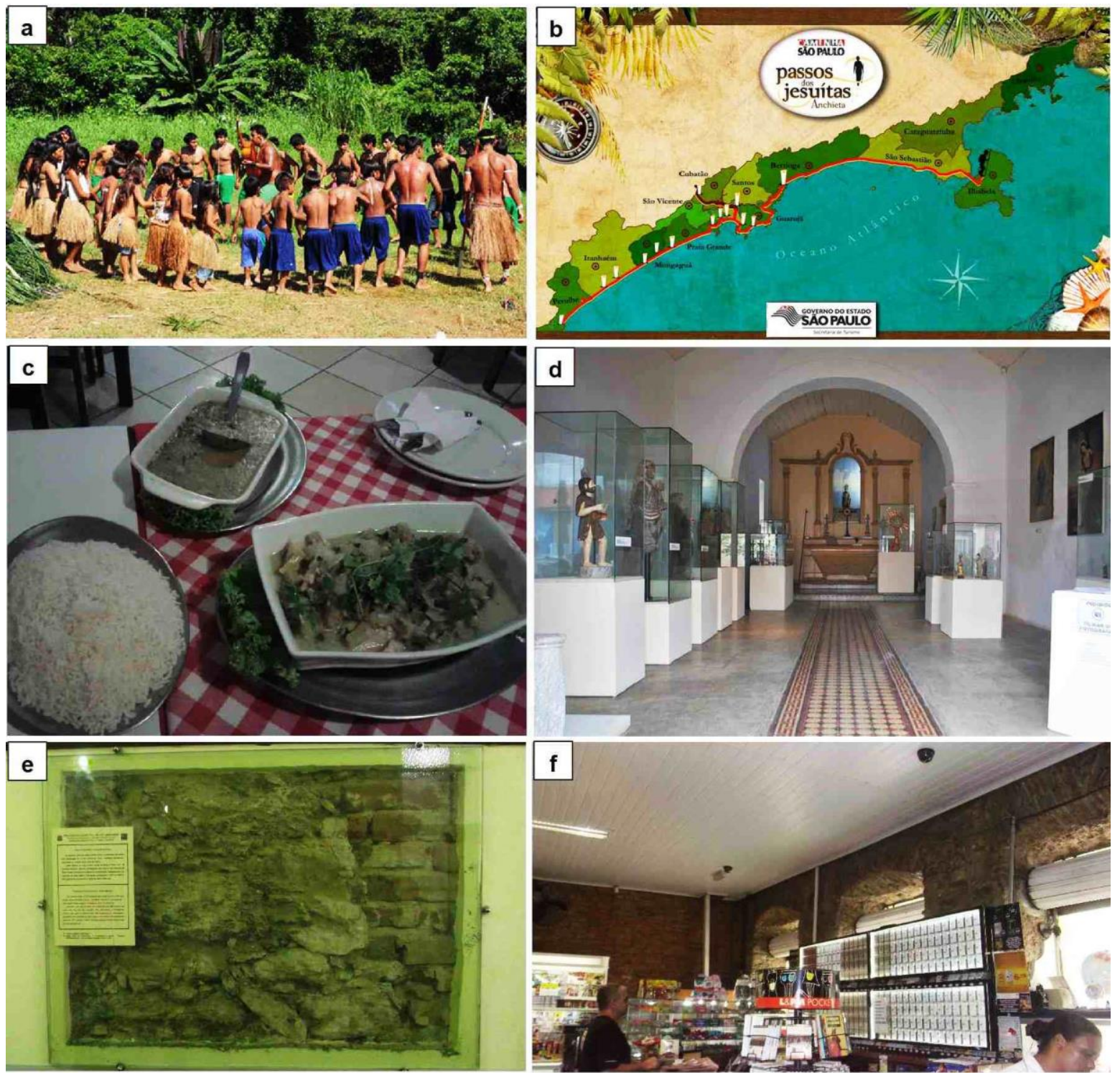

Figura 10 - Aspectos culturais no município de São Sebastião a - Aldeia Indígena Rio Silveira (Fonte: http:www.bertioga.sp.gov.br/turismo); b - Mapa virtual da rota Passos dos Jesuítas (Fonte: http:www.passosdosjesuitas.com.br); c - Gastronomia caiçara, peixe azul-marinho; $d$ - Museu de Arte Sacra; e - parede original preservada dentro da Secretaria de Turismo; $f$ - parede original preservada em comércio local.

\subsubsection{Geoturismo em Ilhabela}

O patrimônio geológico de llhabela (PROCHOROFF, 2014) possui dois geossítios sem potencial para o turismo por não apresentaram valores significativos nos parâmetros de quantificação: "Acessibilidade" e "Beleza Cênica", que são os geossítios: Diques da Ponta da Sela e Gabros Estratiformes, indicados apenas os usos para fins educativos e científicos.

O patrimônio cultural do município é rico em vestígios do período colonial e do tráfico negreiro do Brasil, além do patrimônio construído Antigo Mercado de escravos (Figura 11a). A atual Praça Coronel Júlio de Moura 
Negrão abriga remasnescentes do pelourinho da llhabela, local onde os escravos eram acorrentados e chicoteados como castigo e representa um importante registro de um período da história do Brasil (Figura 11b).

O município apresenta um território reconhecido composto por comunidades tradicionais caiçaras na Baía de Castelhanos, abrangendo as praias da Figueira, Vermelha, Ribeirão, Saco do Sombrio, Mansa e Canto da Lagoa, e das llhas de Vitória, Búzios e Pescadores. Neste território está inserido o Geossítio Praia da Figueira e o sítio da geodiversidade Praia de Castelhanos, locais apresentados no mapa geoturístico e que podem ser explorados de forma sustentável por essas comunidades tradicionais a fim de beneficiá-las economicamente e socialmente, fortalecendo suas raízes e apresentando aos visitantes aspectos tradicionais e "saber-fazer" da cultura caiçara.
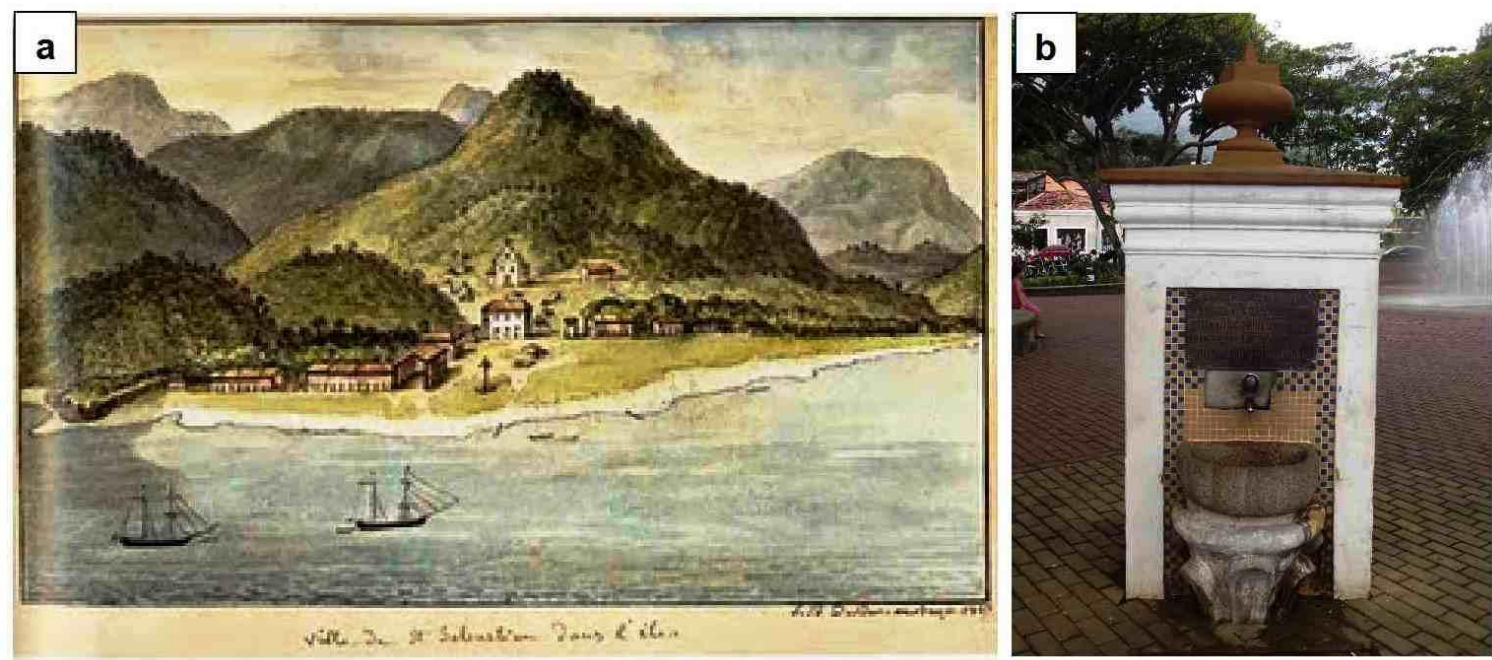

Figura 11 - Patrimônio Cultural em Ilhabela. a - Antigo Mercado de Escravos registrado na pintura do artista Debret, em 1827; b - antigo pelourinho localizado na Praça Coronel Júlio de Moura Negrão.

\subsubsection{Geoturismo em Caraguatatuba}

Dentre os geossítios avaliados quantitativamente no município, o Geossítio Milonitos e Cataclasitos da Estrada da Petrobas não apresentou valor suficiente para uso turístico, apresentando melhor uso potencial no contexto educativo em nível universitário, por tratar de temas muito específicos às geociências. Em contrapartida, o Geossítio Geoformas de Caraguatatuba apresentou um alto valor de potencial turístico, isso porque no geossítio são abordados, além de aspectos geológicos, geoformas que se assemelham a 
formas conhecidas do imaginário humano, inspirando o surgimento de lendas, como é o caso da Pedra da Freira (Figura 12), e gerando curiosidade dos turistas, atraindo visitantes que vão ao local para ver as geoformas e desfrutam das praias e serviços disponíveis na área. As geoformas são consideradas pontos de referência e de turismo no município, inclusive contendo placas indicativas na avenida principal da cidade, como é o caso da Pedra da Freira e a Pedra do Jacaré, na Prainha.
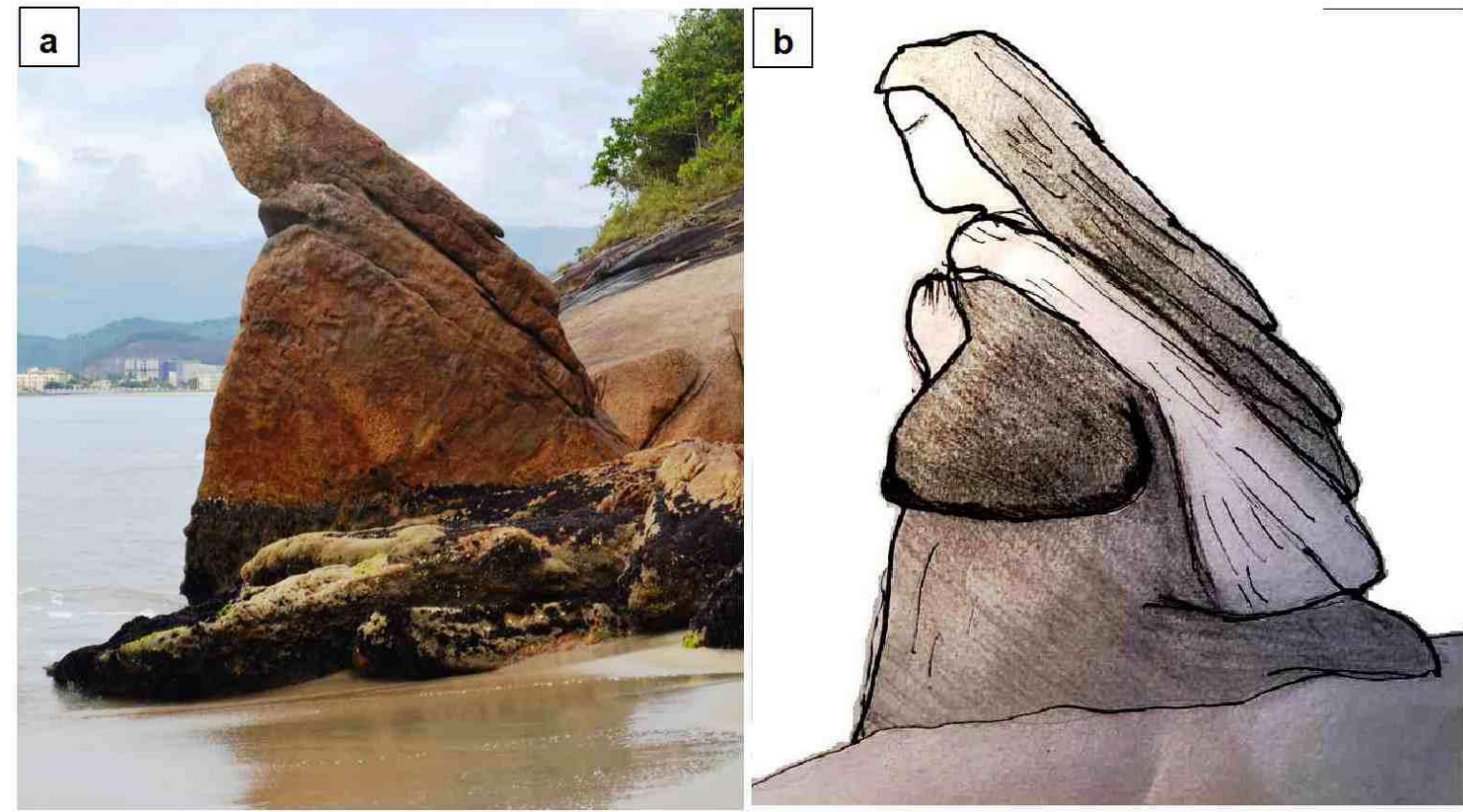

Figura 12 - Geoforma Pedra da Freira; a - aspecto atual da Pedra da Freira, na Praia do Garcez; b - ilustração representando a lenda associada à geoforma, que diz que uma freira teria morrido afogada no local e, em sua homenagem, Deus petrificou sua imagem rezando ajoelhada para que a freira seja sempre lembrada pelos moradores locais. O manto da Freira é formado pelas fraturas que seguem a foliação da rocha.

O Geossítio Morro do Santo Antônio, além de ser um ponto de encontro religioso e destino de peregrinação de religiosos, é um local de acesso às rampas para práticas de voo livre, possuindo duas rampas construídas exclusivamente para a prática do esporte (Figura 13). Atualmente o geossítio possui um painel interpretativo da paisagem geológica onde se avista: a Serra do Mar, a Planície de Caraguatatuba, algumas ilhas e morros com registros dos escorregamentos de massa que ocorrem no município. Constitui em um geossítio do tipo mirante com alto valor turístico. 


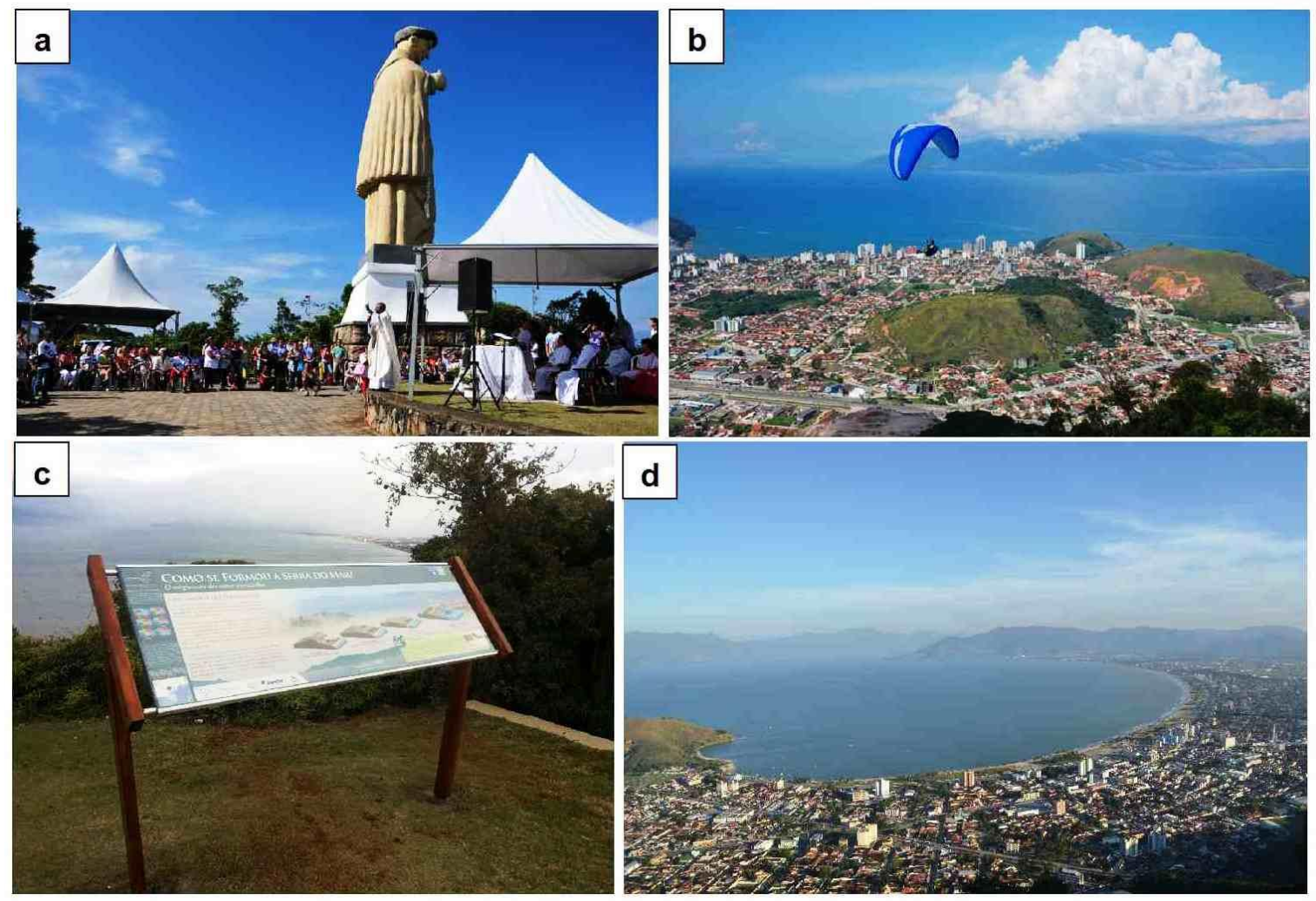

Figura 13 - Morro do Santo Antônio em Caraguatatuba. a - Comemoração do mês de Santo Antônio no Morro do Santo Antonio. Fotos: Gianni D’ Angelo; b - Prática de voo livre no Morro do Santo Antônio, Caraguatatuba (Foto: Gustavo Grunewald); c - painel interpretativo (Foto: Maria da Glória); $d$ - Vista à partir do mirante do Morro do Santo Antônio.

No mapa geoturístico de Caraguatatuba, o patrimônio cultural está representado por 3 pontos no mapa que correspondem ao museu, ao artesanato e a comunidade caiçara. O Museu de Arte e Cultura de Caraguatatuba - MACC, está localizado no centro do município em frente aos dois patrimônios construídos: Paróquia Matriz Santo Antônio e o Relógio do Sol. O museu está localizado em uma casa onde funcionava uma antiga escola no município. Na área interna do museu existe uma sala de exposição permanente onde está exposto um panorama da história do município com fotos, textos e objetos antigos. O museu dispõe de um arquivo público, onde estudantes e pesquisadores podem acessar livros, documentos e fotos antigas do município (Figura 14).

O ponto representado pelo Artesanato no mapa geoturístico refere-se ao Núcleo de Cerâmica Artesanal Terramar, um ateliê de cerâmica inserido na "Rota da Cerâmica", uma rota destinada aos ceramistas locais. A rota passa por vários ateliês onde os artesãos expõem seus trabalhos realizados com 
argila. Dentre estes, destaca-se o Núcleo de Cerâmica Artesanal Terramar caracterizado pela confecção de peças utilizando-se técnicas indígenas, como é o caso do artesão Ben-Hur, proprietário do Terramar, que repassa essas técnicas para outros artesãos através de oficinas (Figura 15). O Núcleo de Cerâmica Terramar consiste no principal ponto de concentração dos ceramistas da cidade e possui uma localização privilegiada na Praia de Porto Novo ao lado do sítio da geodiversidade Foz do Rio Juqueriquerê.
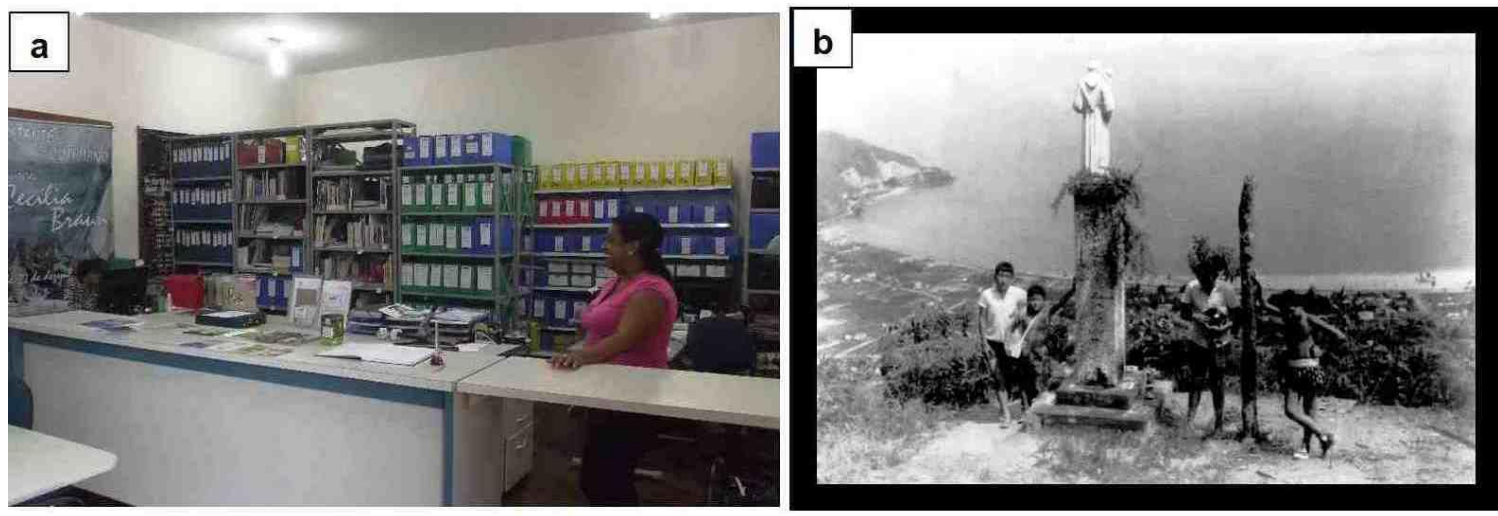

Figura 14 - Arquivo Público de Caraguatatuba. a - biblioteca do arquivo público de Caraguatatuba; $b$ - foto antiga do Morro do Santo Antônio disponibilizada pelo Arquivo Público (sem data).
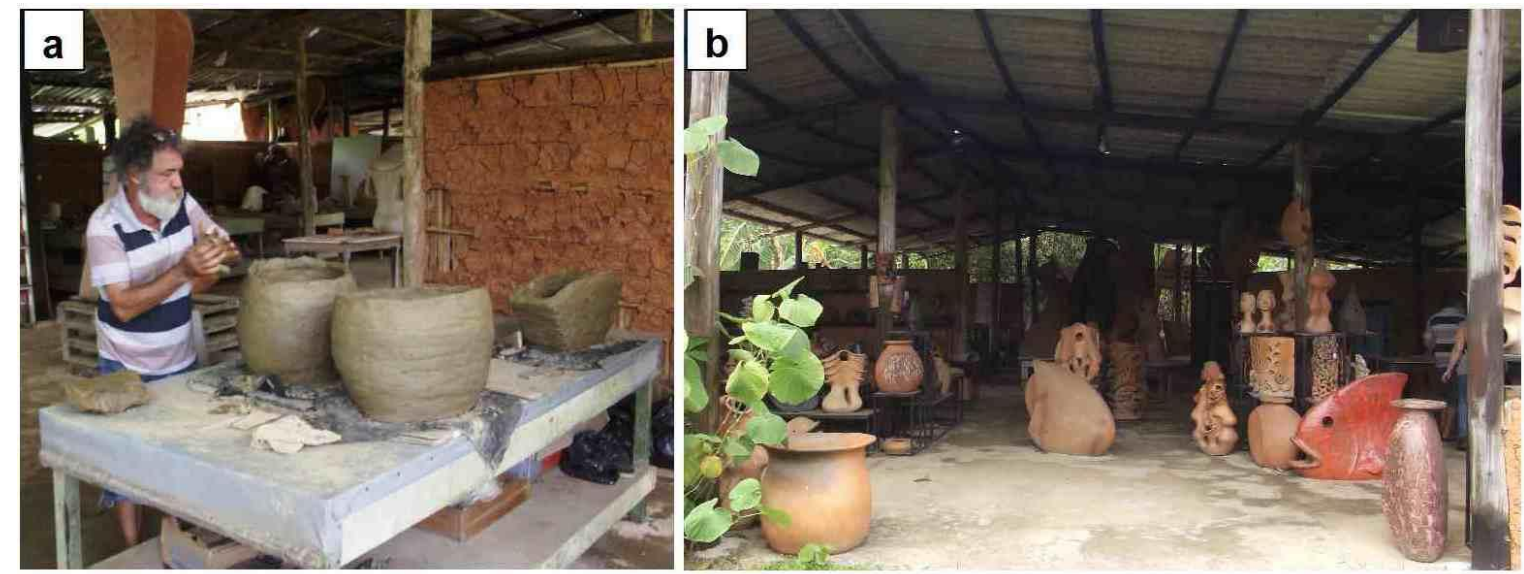

Figura 15 - Núcleo de Cerâmica Artesanal Terramar em Caraguatatuba. a - Artesão Ben-Hur manipulando a argila com técnicas indígenas para criar a peça de cerâmica; $b$ - Entrada do Ateliê Terramar com exposição de peças confeccionadas no local à venda.

A Comunidade Pesqueira da Praia do Camaroeiro consiste em uma comunidade caiçara que realiza suas atividades de pesca. Embora a comunidade caiçara tenha se estabelecido nesta praia originalmente no ano de 1927 (PETROBRAS, 2009), com o intenso crescimento urbano do município na 
segunda metade do século XX e o alta especulação imobiliária, a comunidade caiçara que vivia nesta praia foi dispersada e reestabelecida nas regiões periféricas do município (FONSECA, 2013).

O município contém destinos específicos para esportistas radicais, como a "Estrada da Petrobras" (como é conhecida), que se constitui em uma estrada de terra com origem no município de Salesópolis e destino final em Caraguatatuba. Com percurso descendo as escarpas da Serra do Mar e passando por rios e cachoeiras, é uma rota muito utilizada por praticantes de ciclismo de aventura. Essa rota passa pelo Geossítio Milonitos e Cataclasitos da Estrada da Petrobras que, mesmo sem conter valor turístico, poderia ser instalada uma placa informativa, explicando aos ciclistas que naquele ponto existe um geossítio de importância geológica estrutural na região, uma representação da Zona de Cisalhamento Camburu (Figura 16).
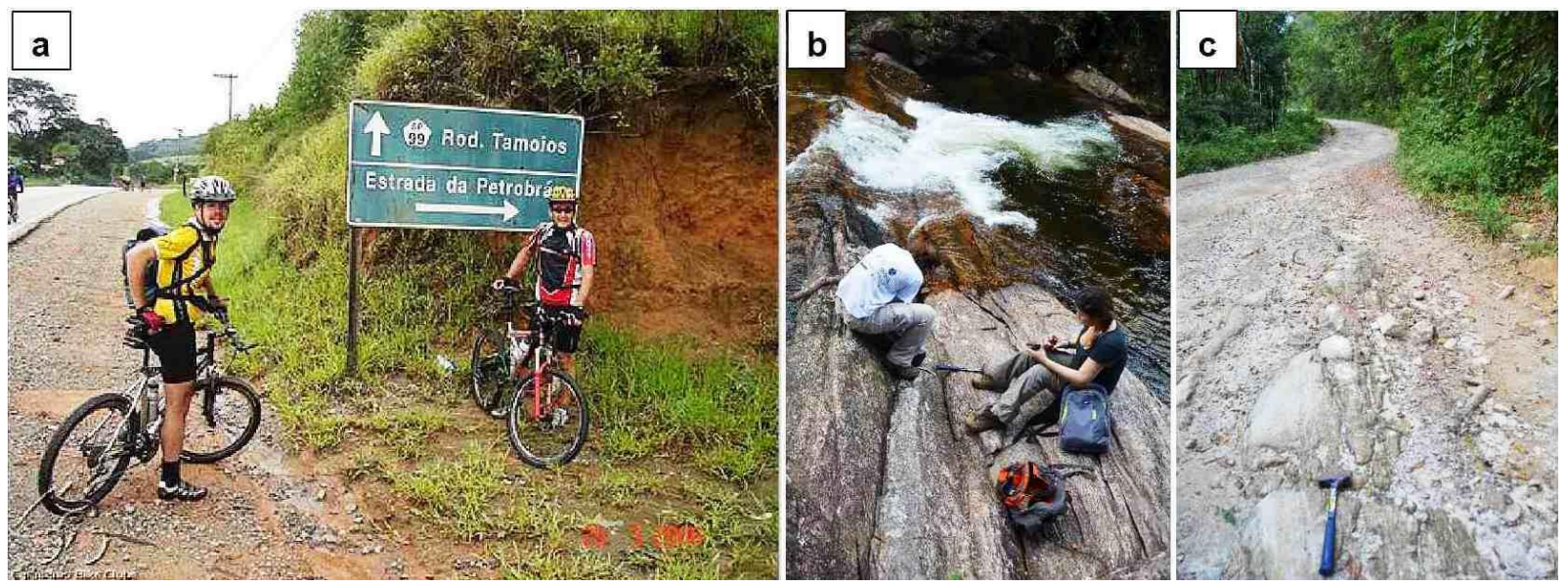

Figura 16 - Estrada da Petrobras. a - prática de ciclismo de aventura na Estrada da Petrobras, (Fonte: https://www.pedal.com.br/); b - Geossítio Milonitos e Cataclasitos da Estrada da Petrobras; $c$ - afloramentos de gnaisse milonítico na estrada.

\subsubsection{Geoturismo em Ubatuba}

A avaliação quantitativa dos geossítios em Ubatuba apresentou três geossítios que não possuem alto valor turístico, sendo eles: Geossítio Praia do Cedro do Sul, Geossítio Monzogranito Ilha Anchieta e Geossítio Brecha Magmática llha Anchieta. Esses geossítios apresentaram o valor igual a zero nos parâmetros "Acessibilidade" e "Beleza cênica", fazendo com que o valor final do potencial para uso turístico fique abaixo de 200. 
Ubatuba possui um rico patrimônio cultural, com a existência de comunidades tradicionais e as ruínas do antigo Presídio da llha Anchieta, caracterizado por ser um presídio político em 1928 e desativado após uma sangrenta rebelião em 1952.

No mapa geoturístico as comunidades tradicionais estão representadas pelo Quilombo da Fazenda e pela Aldeia Indígena Boa Vista. Ambos os locais foram escolhidos neste trabalho por serem comunidades já adaptadas à visitas turísticas e estudantes de escolas na região.

O Quilombo da Fazenda está localizado no Sertão da Fazenda a menos de $2 \mathrm{~km}$ da sede do PESM - Núcleo Picinguaba, e inclui a Casa da Farinha (Figuras 17a e 17b). Trata-se de um antigo engenho de milho, cana de açúcar e álcool construído no final do século XIX e atualmente em atividade com a produção de farinha de mandioca pela comunidade quilombola. No local ocorrem rodas de conversa entre os visitantes e um morador tradicional da comunidade quilombola, que conta como era a vivência antes, durante e depois da implantação do PESM e da Rodovia Rio Santos, além de informações sobre os meios de subsistência, contos e histórias do passado. Das imediações parte a Trilha do Corisco, muitas vezes guiadas pelos moradores locais, representa um antigo caminho utilizado pelos habitantes locais antes da construção da Rodovia RioSantos.

A Aldeia Indígena Boa Vista (Figuras 17c e 17d) está localizada no Bairro do Prumirim e isolada entre os sopés das escarpas da Serra do Mar. $O$ acesso à aldeia é feito por estrada de terra e dista cerca de $1 \mathrm{~km}$ do sítio da geodiversidade Charnockito da Cachoeira do Prumirim. A comunidade vive essencialmente da agricultura e do artesanato (Figuras $17 \mathrm{e}$ e 17f). Alguns habitantes se deslocam todos os dias até o centro de Ubatuba para trabalhar ou vender seus produtos.

A proximidade da Aldeia Boa Vista com o sítio da geodiversidade Charnockito da Cachoeira do Prumirim pode ser uma alternativa para inserir a comunidade indígena no contexto da divulgação da geodiversidade. No local onde está a Cachoeira do Prumirim existe infraestrutura que consiste em um restaurante e estacionamento. Nenhuma informação sobre a rocha 
que constitui a cachoeira e sobre a comunidade indígena que vive próximo dela é fornecida no local.

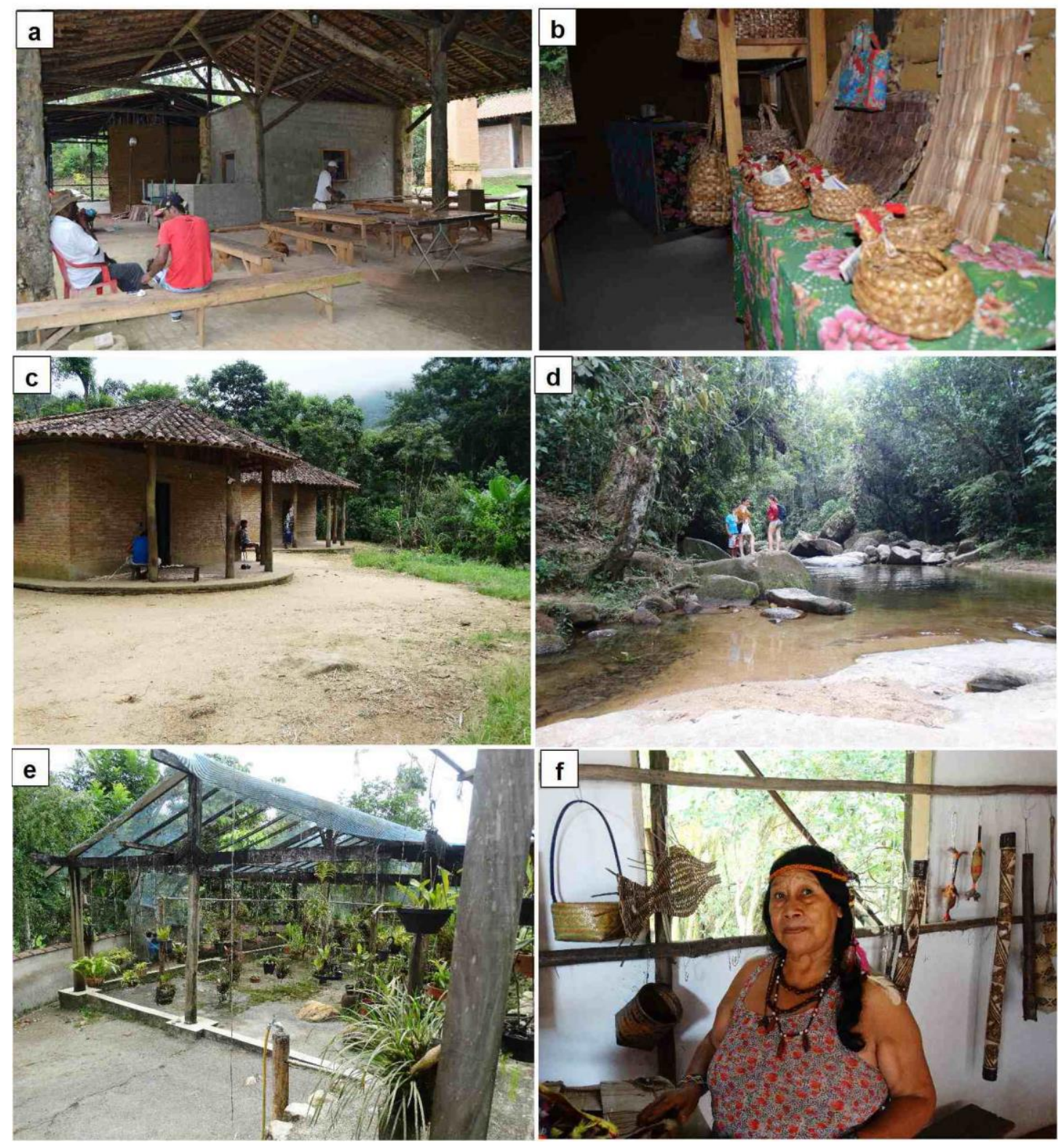

Figura 17 - Comunidades tradicionais em Ubatuba. a - Casa de Farinha, Quilombo da Fazenda; b - artesanato local, Quilombo da Fazenda; c - Aldeia Indígena Boa Vista; $d$ - trilha que leva à Aldeia Indígena Boa Vista, acompanhando o curso do Rio Prumirim com disposição de alguns blocos de charnockito; e - horta para educação ambiental dentro da Aldeia Indígena Boa Vista; f - artesanato confeccionado pelas mulheres da aldeia.

A oportunidade de relacionar a aldeia indígena e o sítio da geodiversidade está em inserir esses índios no contexto comercial que existe ao redor da cachoeira, seja no restaurante com sua gastronomia típica, ou oferecendo outros serviços, como venda de seu artesanato. Dessa forma, o índio que necessita se deslocar todos os dias até a cidade 
para trabalhar poderia oferecer seu trabalho neste sítio da geodiversidade, como guias de geoturismo que levam os turistas que já vão à cachoeira, para conhecer a trilha que leva a sua aldeia, explicando o contexto geológico do local para os visitantes, ajudando a divulgar a cultura indígena local e também a geodiversidade.

Ubatuba apresenta em seu patrimônio cultural o Antigo Presídio da Ilha Anchieta, o Projeto TAMAR, o artesanato local e o marco geográfico por onde passa o Trópico de Capricórnio, representado pela Praça do Capricórnio (Figura 18).

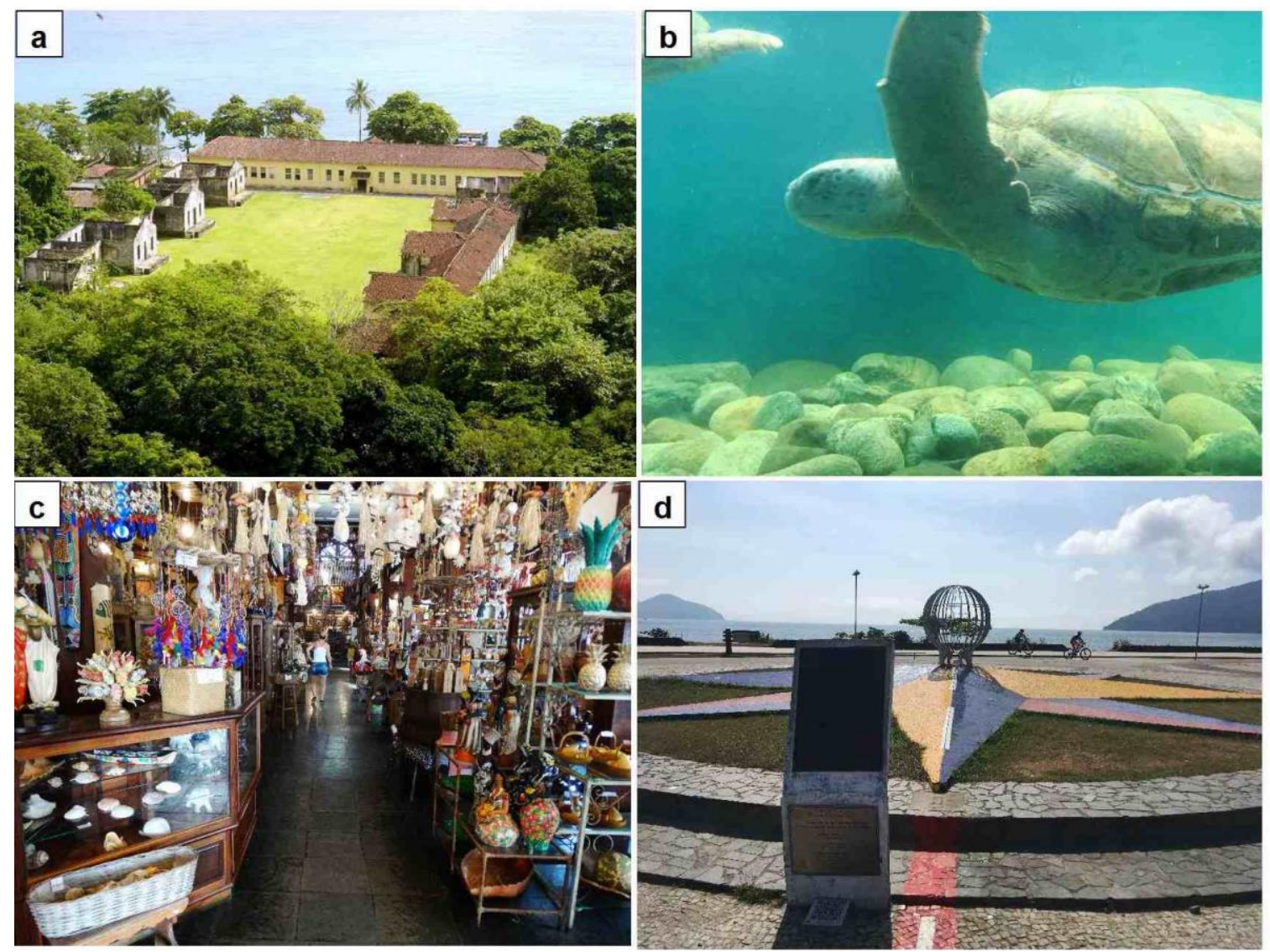

Figura 18 - Atrações turísticas em Ubatuba. a - Antiga cadeia na Ilha Anchieta (Fonte: https://www.litoralbrasileiro.com.br/sp/ubatuba/ilha-anchieta.htm); b Projeto Tamar; c - Artesanato local; d - Marco geográfico do Trópico de Capricórnio. 


\subsection{PROPOSTAS DE ESTRATÉGIAS DE GEOCONSERVAÇÃO PARA O LITORAL NORTE DE SÃO PAULO}

A partir da discussão gerada nesta tese, foi possível propor algumas estratégias de geoconservação que podem ser incluídas em uma proposta geoturística para a região.

\subsubsection{Articulação dos possíveis atores para a gestão do geoturismo no litoral norte de São Paulo}

O mapa geoturístico representa uma estratégia de valorização e divulgação da geodiversidade. Para consolidar uma proposta geoturística é necessário estabelecer uma sólida gestão com a participação de atores sociais em todas as esferas. Na Tabela 13 estão representados alguns atores sociais existentes litoral norte de São Paulo.

Tabela 13 - Tabela preliminar de possíveis atores sociais na gestão do geoturismo no litoral norte de São Paulo.

\begin{tabular}{|c|c|}
\hline Competência & Órgão/Instituição \\
\hline Federal & $\begin{array}{ll}\text { - } & \text { Fundação Nacional do Índio (FUNAI) } \\
\text { - } & \text { Ministério do Meio Ambiente - Unidades de Conservação }\end{array}$ \\
\hline Estadual & $\begin{array}{l}\text { - } \quad \text { Parque Estadual da Serra do Mar (PESM) } \\
\text { - } \quad \text { Parque Estadual de llhabela (PEI) } \\
\text { - } \quad \text { Parque Estadual da llha Anchieta (PEIA) } \\
\text { - Área sob Proteção Especial Estadual (ASPE) } \\
\text { - Área de Relevante Interesse Ecológico de São Sebastião (AIRE) }\end{array}$ \\
\hline Municipal & $\begin{array}{ll}\text { - } & \text { Prefeituras } \\
\text { - } & \text { Secretarias de Turismo } \\
\text { - } & \text { Secretarias de Educação } \\
\text { - } & \text { Fundaçõas do Meio Ambiente } \\
& \text { Caraguattura (FUNDASS - São Sebastião, FUNDACC - } \\
& \text { - FUNDACI - Ilhabela e FUNDART - Ubatuba) }\end{array}$ \\
\hline Particular & $\begin{array}{l}\text { - } \text { Reserva Particular do patrimônio Natural (RPPN) } \\
\text { - } \text { Agências de Turismo } \\
\text { - } \text { Setor Hoteleiro } \\
\text { - } \quad \text { Artesãos }\end{array}$ \\
\hline Sociedade & $\begin{array}{ll} & \text { Representantes de Comunidades locais } \\
\text { - } & \text { Representantes das Comunidades Tradicionais }\end{array}$ \\
\hline
\end{tabular}

Entre os atores com poder federal para auxiliar e intervir no geoturismo está a FUNAI, representada no litoral norte de São Paulo pelas áreas de reserva indígena onde estão localizadas a Aldeia Indígena Rio Silveiras, em São Sebastião, e a Aldeia Indígena Boa Vista, em Ubatuba. A FUNAI 
estabelece o controle ao acesso de visitantes na Aldeia Rio Silveiras que, mesmo a população indígena dessa aldeia sendo "amigável" à entrada de turistas e escolas para visitação na aldeia, para entrar na aldeia é necessário a aprovação da FUNAI.

$\mathrm{Na}$ esfera de poder estadual estão os Parques Estaduais (PESM, PEI e PEIA), responsáveis pela preservação da biodiversidade na região e atuantes em ações de educação ambiental. A Área sob Proteção Especial Estadual (ASPE) está representada na região no município de São Sebastião - ASPE Costão de Boiçucanga, e abrange o Geossítio Mirante da Praia Brava e o Sítio da Geodiversidade Praia Brava. No município de São Sebastião há uma Área de Relevante Interesse Ecológico (AIRE) que corresponde ao Centro de Biologia Marinha da Universidade de São Paulo (CEBIMar) onde está localizado o Geossítio Praia do Cabelo Gordo.

É de competência municipal as ações das prefeituras dos municípios, das secretarias municipais de turismo, de educação e do meio ambiente, e das fundações de cultura: Fundação Educacional e Cultural de São Sebastião Deodato Sant'Anna - FUNDASS; Fundação Educacional e Cultural de Caraguatatuba - FUNDACC; Fundação de Arte e Cultura de Ilhabela FUNDACI; Fundação de Arte e Cultura de Ubatuba - FUNDART.

As entidades ou instituições privadas também devem participar do geoturismo, agências de turismo, setor hoteleiro, comerciantes e artesãos locais são a estrutura de apoio logístico. Entre as iniciativas privadas podem estar inseridas as RPPNs, como a Reserva Rizzieri em São Sebastião que incorpora o Geossítio Milonitos da Zona de Cisalhamento Camburu.

Por fim, os atores sociais mais importantes no geoturismo estão representadas pelas comunidades locais e tradicionais, são elas que devem receber e se beneficiar com o desenvolvimento gerado através do geoturismo na região. Como atores principais, a sociedade deve estar presente em todas as etapas de um plano geoturístico.

\subsubsection{Serviços e potencial socieconômico}

O litoral norte de São Paulo apresenta potencial para geração de empregos a partir do geoturismo, com restaurantes localizados em geossítios como é o caso do Geossítio Pedra do Sino em Ilhabela, contendo um 
restaurante no local do geossítio que dispõe de martelos para os clientes martelarem as rochas do geossítio e ouvirem o som emitido pelos fonolitos. Outro exemplo é o Geossítio Charnockito Ubatuba, em Ubatuba, possui um restaurante especializado em gastronomia caiçara instalado sobre um afloramento de charnockito. Esses locais representam o potencial econômico que pode ser gerado através da geodiversidade, servindo como exemplos de serviços privilegiados pelo geoturismo.

O retorno socioeconômico do geoturismo deve beneficiar a população local, introduzindo as comunidades tradicionais e marginalizadas no contexto econômico da região. A contratação de moradores locais para monitoramento ambiental já existe nas sedes do PESM, recebendo o treinamento necessário para conduzir os turistas e visitantes nas trilhas do PESM. As comunidades tradicionais também podem ter seus produtos artesanais destacados pela divulgação em conjunto com o geoturismo (Figura 19).
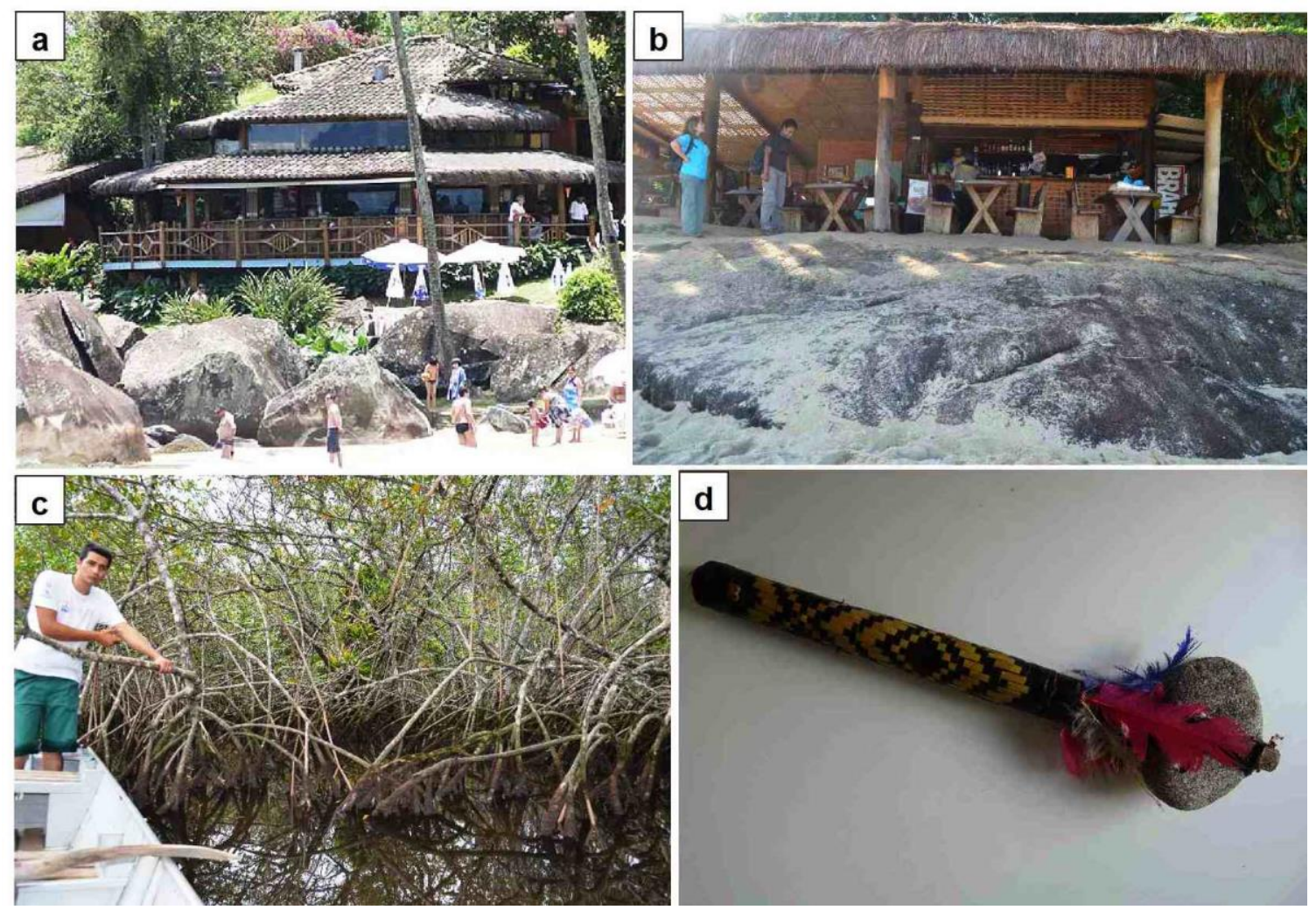

Figura 19 - Exemplos de serviços e produtos que podem ser incrementados através do geoturismo no litoral norte de São Paulo. a - Restaurante Pedra do Sino, localizado no Geossítio Pedra do Sino em Ilhabela, dispõe de martelos para os clientes ouvirem os fonolitos do geossítio; b - restautante especializado em gastronomia caiçara localizado sobre um afloramento de Charnockito no Geossítio Charnockito Ubatuba, em Ubatuba; c - monitor ambiental do PESM explicando a sedimentação do mangue 
durante a Trilha Fluvial no Rio Fazenda; $d$ - artesanato indígena confeccionado com rochas locais.

\subsubsection{Propostas de centros interpretativos}

Este estudo, sugere a instalação de centros de interpretação no litoral norte de São Paulo, com o objetivo de abordar os pontos geoturísticos e seus aspectos geológicos e unificar todas as informações do município em um único local, para que o visitante tenha um centro de apoio e de informações sobre o mapa geoturístico e de como chegar nos pontos geoturísticos.

Esses centros devem, preferencialmente, ser visitados antes de explorar os pontos do mapa geoturístico, para que o visitante possa organizar sua rota de acordo com seu interesse e visitar os pontos com um algum conhecimento geológico sobre o local.

Para a instalação de centros de interpretação na região são necessárias parcerias com instituições governamentais e iniciativas privadas, sendo de extrema importância a participação da sociedade.

Neste trabalho, foram analisado locais na região com potencial para serem centros interpretativos. Em São Sebastião, a sede do PESM - Núcleo São Sebastião oferece a infraestrutura necessária para a criação de um centro de interpretação da geodiversidade (Figura 20). Localizado ao lado do sítio da geodiversidade Mirante Barra do Una, esta sede conta com estacionamento, espaço para exposição e apresentações, espaço para pesquisa, banheiros e cozinha.

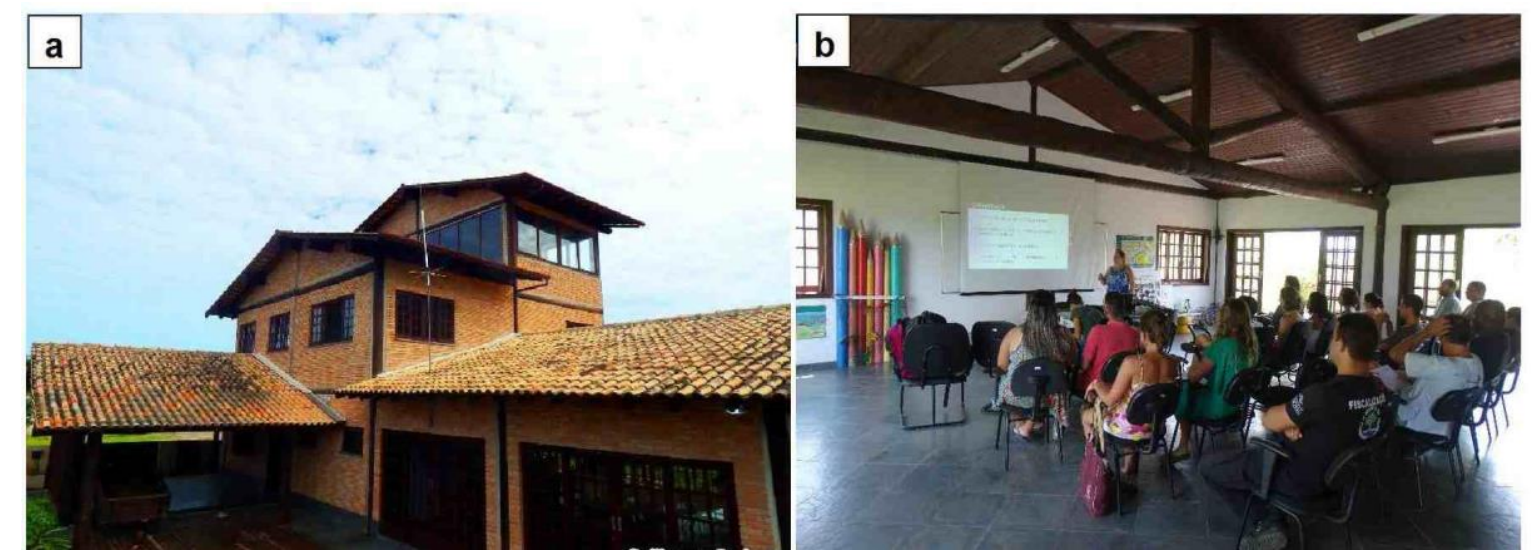

Figura 20 - Sede do PESM - Núcleo São Sebastião. a - Estrutura externa (Fonte: http://www.parqueestadualserradomar.sp.gov.br/pesm/nucleos/sao-sebastiao/); b Estrutura interna com espaços para apresentações e recursos multimídia. 
Em Ilhabela existe um espaço que explora alguns aspectos da geodiversidade local, a sede do Parque Estadual de Ilhabela (Figura 21), localizado no centro histórico do município e próximo aos dois partrimônios construídos inventariados neste trabalho: Antigo Mercado de Escravos e Paróquia Nossa Senhora D’Ajuda. Como o local já fornece algumas informações básicas da geodiversidade, sugere-se a adição de informações direcionadas ao geoturismo na ilha e informações diretas sobre a geologia de seus pontos.
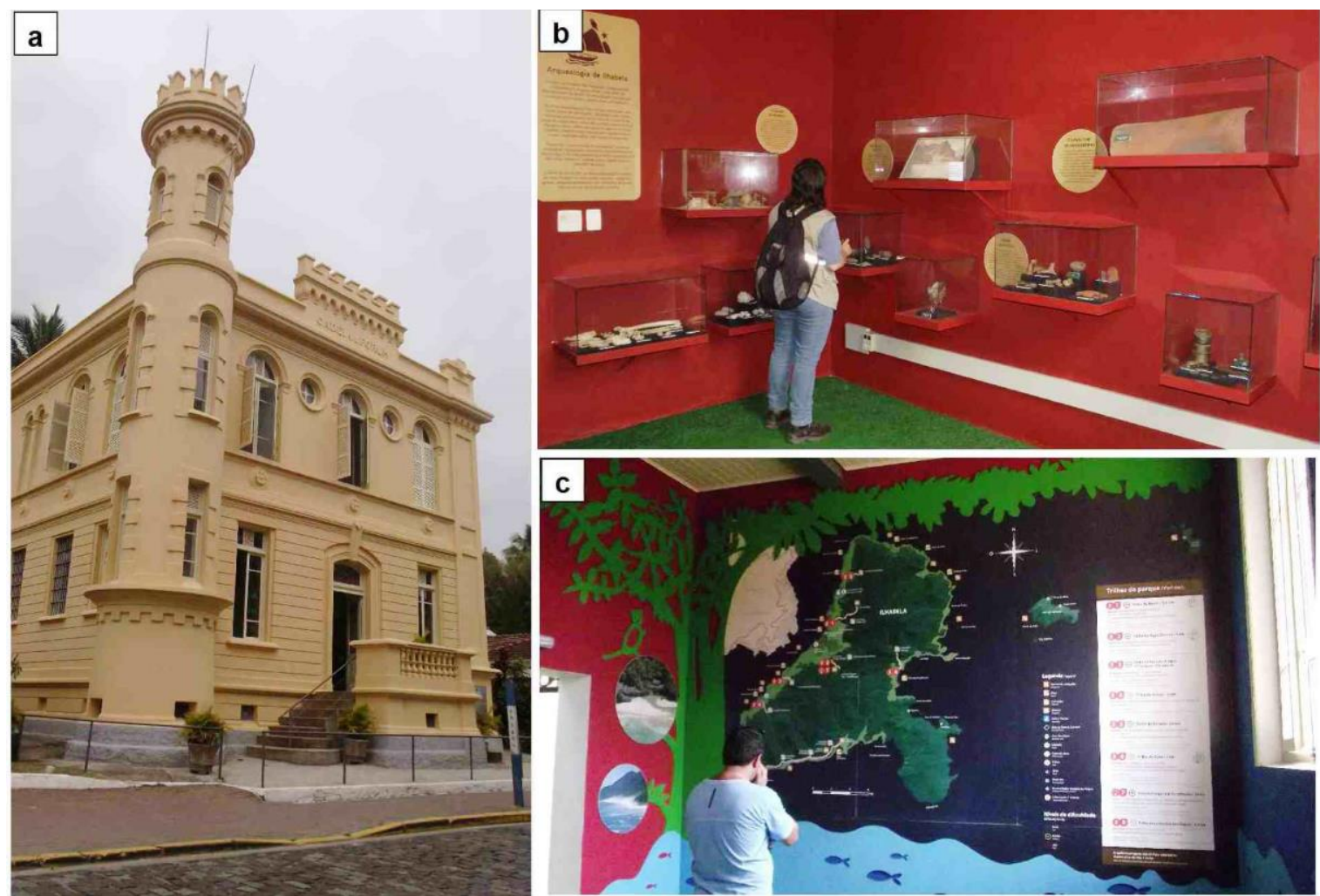

Figura 21 - Sede do Parque Estadual de Ilhabela; a - sede localizada no antigo fórum e cadeia da cidade; b - exposição interna sobre a história arqueológica na ilha; c exposição sobre a natureza na ilha.

No município de Caraguatatuba, por estar localizado no centro da região, sugere-se um centro de interpretação da geodiversidade do litoral norte de São Paulo, com a união das informações dos pontos geoturísticos dos 4 municípios em um único local. Caraguatatuba já possui o painel síntese do litoral norte instalado no calçadão da Praia de Caraguatatuba, centro da cidade. O local sugerido para a implantação deste centro é o atual Museu de Arte e Cultura de Caraguatatuba - MACC (Figura 22), localizado na rua Santa Cruz, 
centro de Caraguatatuba, em frente aos dois patrimônios construídos: Paróquia Santo Antônio e Relógio do Sol, e no sítio da geodiversidade: Gnaisse da Paróquia. O local já apresenta uma exposição sobre o meio ambiente, mas assim como em llhabela, este é abordado de modo geral e seria necessário a adição de informações específicas da geologia dos pontos geoturísticos da região.

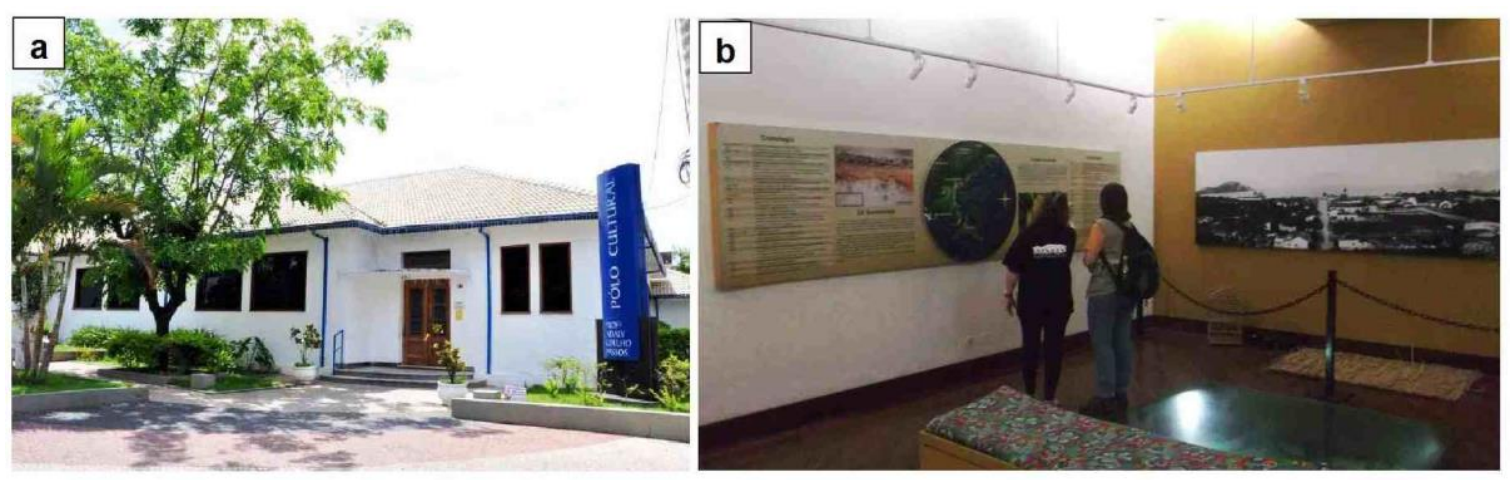

Figura 22 - Museu de Arte e Cultura de Caraguatatuba - MACC. a - entrada do museu; $b$ - exposições na área interna do museu.

Em Ubatuba, o local que apresentou potencial para centro interpretativo da geodiversidade do município foi a sede do PESM - Núcleo Picinguaba (Figura 23), por apresentar um espaço com exposição sobre o meio ambiente e por estar localizado no extremo norte da região recebendo os turistas que vem em direção ao sul, e pela infraestrutura com estacionamento, banheiros e até uma trilha sensorial no espaço da sede. Ademais, o local está situado próximo ao sítio da geodiversidade Praia da Fazenda, sendo o único acesso de carro para esta praia.
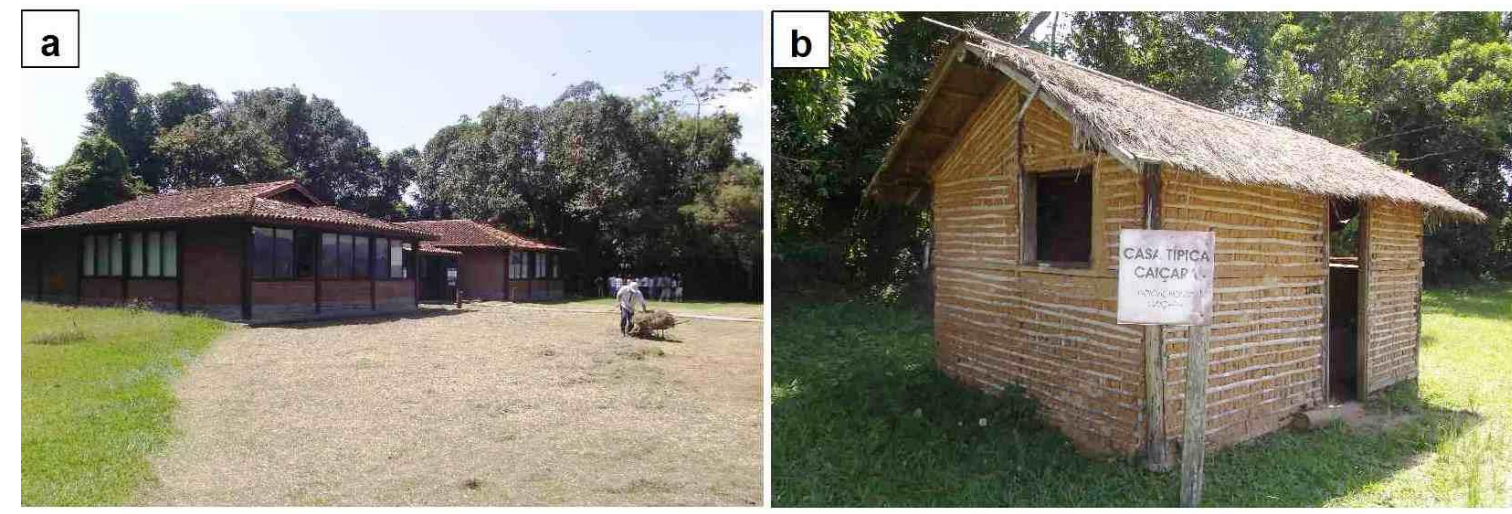

Figura 23 - Sede do PESM - Núcleo Picinguaba; a - casa da Sede; b - exposição de uma casa típica caiçara no local. 
Deve-se ter sempre em mente que o local a ser visitado pelo turista é o lugar vivido pelas pessoas que o recebem. As populações desses espaços podem ser divididas em dois tipos: as que vêem o turismo como uma forma de invasão, afetando diretamente na cultura e nas dinâmicas sociais locais; e as que esperam do turismo oportunidades para melhorar seu sustento e qualidade de vida. Por tanto, em qualquer tipo de turismo a troca cultural é fundamental, e não pode ser colocada em último plano. Esse fato nos leva a crer que o geoturismo é, além de um estudo interdisciplinar, também uma ciência social. 


\section{CONSIDERAÇÕES FINAIS}

Este trabalho objetivou apresentar o mapa geoturístico como uma proposta de geoconservação para o litoral norte do estado de São Paulo. O mapa descrito neste trabalho apresenta os locais com potencial para o geoturismo e constitui um objeto acadêmico para a aplicação em políticas públicas, não representando o mapa geoturístico final a ser apresentado para a sociedade.

Para a elaboração do mapa geoturístico foi realizado nesta tese 0 inventário e avaliação quantitativa do patrimônio geológico de Caraguatatuba e dos sítios da geodiversidade do litoral norte de São Paulo; o inventário de sítios do patrimônio construído do litoral norte de São Paulo; e a integração da geodiversidade com o patrimônio cultural da região. Por fim, foram propostas estratégias de geoconservação à partir do mapa geoturístico.

Para a realização do inventário dos geossítios de Caraguatatuba foi utilizado como base geológica o mapa geológico do estado de São Paulo (PERROTTA et al., 2005), levantamentos bibliográficos e trabalhos de campo. Para o levantamento dos sítios da geodiversidade e do patrimônio construído foi necessário o levantamento geológico e cultural da região. O método utilizado para a avaliação quantitativa do patrimônio geológico e dos sítios da geodiversidade foi o de Brilha (2016), utilizando-se a plataforma Geossit (ROCHA et al., 2016).

À partir do mapa geoturístico gerado através dos inventários, foi possível elaborar uma estratégia de geoconservação baseada no geoturismo e propor meios de valorização e divulgação da geodiversidade. Pretende-se com o produto desta tese, instigar o interesse da sociedade e das instituições públicas e privadas a participar em conjunto da elaboração das propostas sugeridas e enaltecer a importância da geoconservação antes de tudo. O geoturismo apenas será concretizado quando a geodiversidade estiver assegurada de todas as ameaças que possam advir com o turismo desinformado e o vandalismo.

Esta tese defende a utilização de métodos científicos como base para a elaboração de um mapa geoturístico. É necessário um levantamento detalhado acerca da geodiversidade local e regional e a realização de inventários do 
patrimônio geológico, dos sítios da geodiversidade e dos sítios do patrimônio construído, a fim de selecionar os locais de importância geológica que apresentam potencial para a exploração geoturística, para a divulgação científica e sua possibilidade de ser incorporado em políticas que possam gerar benefícios socioecônomicos para as comunidades em seu entorno.

Durante o desenvolvimento da tese a preocupação em como estabelecer uma gestão apropriada para a aplicação do geoturismo esteve presente em todas as etapas, com a realização de reuniões com representantes do PESM, das secretarias de turismo, com representantes comerciais e com a própria população. A partir do que foi discutido em conjunto com estas instituições e baseado no estudo desta tese, acredita-se que a melhor estratégia política para o geoturismo é inseri-lo na gestão do patrimônio natural. Fazer com que o patrimônio geológico seja entendido como parte fundamental do patrimônio natural pode auxiliar tanto nas políticas de geoconservação quanto nas políticas legislativas, visto que, um dos grandes problemas quando abordamos a temática da geodiversidade é a ausência de leis específicas que protejam o patrimônio geológico.

O mapa geoturístico é apenas o ponto inicial para estabelecer as próximas ações, direcionadas à gestão, com 0 apoio de parcerias governamentais e privadas e da sociedade. Com isso em mente, sabe-se que a aplicação do geoturismo consiste em um processo lento que demanda, além de parcerias, investimentos para a elaboração de materiais de divulgação e a construção de estruturas físicas em alguns pontos, e o desafio maior da intermunicipalidade na gestão do território.

O mapa geoturístico resultante neste trabalho consiste em um produto que fundamenta a importância do geoturismo para a conservação da geodiversidade. Com o levantamento científico apresentado, a aplicação do geoturismo torna-se mais embasada e justificada. O presente trabalho oferece uma alternativa para a descentralização do turismo na região, com uma abordagem geológica levando em conta o turismo sustentável, destacando a importância da percepção e compreensão da paisagem e do patrimônio geológico como parte de um todo. 


\section{REFERÊNCIAS}

ARANA, R.; RODRíGUEZ ESTRELLA, T.; MANCHEÑO, M.A. \& ORTIZ SILLA, R. 1992. Lugares de interés geológico de la Región de Murcia. Murcia, Agencia regional para el medio ambiente y naturaleza. $219 p$.

ARRUDA, K.E.C.; GARCIA, M.G.M. \& DEL LAMA, E.A. 2015. Geological Heritage Inventory as a Subsidy for Geotourism: Caraguatatuba - São Paulo State, Brazil. In: INTERNATIONAL PROGEO SYMPOSIUM, 8, Reykjavik, 2015. ProGEO programme and abstracts, Reykjavik, p. 68-69.

ARRUDA, K.E.C.; GARCIA, M.G.M.; DEL LAMA, E.A. 2017a. Inventário Geológico do Patrimônio Construído no Litoral Norte do Estado de São Paulo, Brasil. Boletim Paranaense de Geociências, Paraná, 73 (1): 15-33.

ARRUDA, K.E.C.; GARCIA, M.G.M.; DEL LAMA, E.A. 2017b. Inventário e Avaliação Quantitativa do Patrimônio Geológico do município de Caraguatatuba, São Paulo. Geociências, UNESP, São Paulo, 36 (3): 447 462.

ARRUDA, K.E.C; GARCIA, M.G.M; DEL LAMA, E.A.; MUCIVUNA, V.C; REVERTE, F.C. 2017c. Método de Seleção e Propostas de Uso dos Sítios da Geodiversidade: Exemplo do Litoral Norte do Estado de São Paulo, Brasil. Anuário do Instituto de Geociências .UFRJ, Rio de Janeiro. 40 (3): 32 - 56.

AUGUSTO W.C.B., DEL LAMA E.A. 2011. Roteiro geoturístico no centro da cidade de São Paulo. Terrae Didatica. 7:29-40.

BENDAZOLLI, C. 2011. Breve notícia sobre o cenário de ocupação sambaquieira no arquipélago de llhabela, Estado de São Paulo. In: BASTOS, R.L.\& SOUZA, M.C. (Org.). Patrimônio Cultural Arqueológico: Diálogos, Reflexões e Práticas. 1 ed. São Paulo: IPHAN, p. 148-157.

BRILHA, J. 2005. Patrimônio Geológico e Geoconservação: A conservação da natureza na sua vertente geológica. Braga. Palimage (ed), 173p.

BRILHA, J. 2016. Inventory and Quantitative Assessment of Geosites and Geodiversity Sites: a Review. Geoheritage, 8(2): 119-134.

BUREK, C.V. \& PROSSER, C.D. 2008. The history of geoconservation. London, Geological Society. $312 \mathrm{p}$.

DECLARAÇÃO DE AROUCA. Congresso Internacional de Geoturismo Geotourism in Action - Arouca, 2011. Disponível em: <http://www.geoparquearouca.com/geotourism2011/adm/upload/30.declaracao _de_arouca_pt.pdf>. Acesso em: 18 jun. 2015. 
DEL LAMA, E.A., BACCI, D. C., MARTINS, L., GARCIA, M. G. M., DEHIRA, L. K. 2015. Urban Geotourism and the Old Centre of São Paulo City, Brazil. Geoheritage (2015) 7:147-164.

DIXON, G. 1996. A Reconnaissance Inventory of Sites of Geoconservation Significance on Tasmanian Islands. Hobart, Parks and Wildlife Service. $116 \mathrm{p}$.

DOWLING, R. K. 2009. Geotourism's contribution to local and regional development. In de Carvalho, C., \& Rodrigues, J. (Eds.), Geotourism and Local Development (pp. 15-37). Idanha-a-Nova, Portugal: Camar municipal de Idanha-a-Nova.

DUQUE, L.C.; MURCIA, V.; ABRIL, J.; GARCÍA SALINAS, F. \& ELÍZAGA, E. 1978. Proyecto previo de puntos de interés geológico. Madrid, Instituto Geológico y Minero de España. $47 \mathrm{p}$.

FONSECA, A.S.S. 2013. Caiçaras frente à mudança: Transformações na Comunidade de Camaroeiro em Caraguatatuba/SP (1950-2010). Cadernos do CEOM - Ano 27, n.40 - Histórias Locais e Imaginário Social.

FUERTES-GUTIÉRREZ, I.; FERNÁNDEZ-MARTÍNEZ, E. 2010. Geosites inventory in the Leon Province (Northwestern Spain): a tool to introduce geoheritage into regional environmental management. Geoheritage, 2: 57-75.

FUNDAÇÃO DE ARTE E CULTURA DE UBATUBA - FUNDART. Comunidades. Disponível em: <http://fundart.com.br/tradicao/comunidades/caicara/>. Acesso em: 5 jul. 2017.

GARCIA, M. G. M; DEL LAMA, E. A; MARTINS, L; BOUROTTE, C. 2011. Geotourism potential in the north coast of São Paulo State, Brazil: Aspects of geoconservation, preservation of traditional culture and income generation. In: I INTERNATIONAL GEOTOURISM CONGRESS, Arouca, Portugal, 10.

GARCIA, M.G.M., 2012. Gondwana geodiversity and Geological Heritage: examples from the North Coast of São Paulo State, Brazil. Anuário UFRJ. Geochimica Brasiliensis, v. 2, n. 2, p. 175-183, 1988.

GARCIA, M. G. M; DEL LAMA, E. A; BOUROTTE, C.; MARTINS, L. 2013. Interpretação geológica em trilhas em unidades de conservação: exemplo do Litoral Norte de São Paulo. In: II SIMPÓSIO BRASILEIRO DE PATRIMÔNIO GEOLÓGICO, Ouro Preto, 112.

GARCIA, M. G. M., REVERTE, F. C., MUCIVUNA, V. C., ARRUDA, K. E. C., SANTOS, P. L. DE A., PROCHOROFF, R., \& ROMÃO, R. M. M. 2016. A geodiversidade como parte do meio natural em áreas protegidas: experiência com cursos para monitores ambientais no litoral norte de São Paulo. In: 48 
CONGRESSO BRASILEIRO DE GEOLOGIA. Anais 48 Congresso Brasileiro De Geologia. Porto Alegre - RS.

GARCIA, M.G.M; DEL LAMA, E.A; BOUROTTE, C.L.M; MAZOCA, C.E.M; BACCI, D.C. Bacci; SANTOS, V.M.N. 2017. Geoheritage Inventories As Means, Not Ends: Example Of The Coastal Region Of São Paulo State, Brazil. Patrimonio geológico, gestionando la parte abiótica del patrimonio natural. Cuadernos del Museo Geominero, oㅡ 21. Instituto Geológico y Minero de España, Madrid, 2017. ISBN 978-84-9138-032-0

GARCÍA-CORTÉS, A. \& CARCAVILLA-URQUÍ, L. 2009. Documento metodológico para la elaboración del inventario español de lugares de interés geológico (IELIG), Intituto Geológico y Minero de Espanã, Madrid, versión 11, $61 \mathrm{p}$.

GRAY, M. 2004. Geodiversity: Valuing and conserving abiotic nature. Londres, John Wiley \& Sons. $434 \mathrm{p}$.

GRAY, M. 2013. Geodiversity: Valuing and conserving abiotic nature. $2^{\text {nd }}$ Edition. Londres, John Wiley \& Sons. 508 p.

HENRIQUES, M.H; PENA DOS REIS, R; BRILHA, J.B; MOTA, T. 2011. Geoconservation as a emerging geoscience. Geoheritage. 3(2):117-128.

HOSE, T.A. 1995. Selling the Story of Britain's Stone. Environmental Interpretation, 2: 16-17.

HOSE, T. A. 2008. Towards a history of Geotourism: definitions, antecedents and the future. In Burek, C. V., \& Prosser, C. D. (Eds.), The History of Geoconservation (pp. 37-60). London: The Geological Society.

HOSE, T. A. 2012. 3G's for modern geotourism. Geoheritage, 4, 7-24. DOI: 10.1007/s12371-011-0052-y.

INSTITUTO BRASILEIRO DE GEOGRAFIA E ESTATÍSTICA. 2007. Residências Secundárias no Total de Domicílios por Município. Disponível em: <http://cidades.ibge.gov.br>. Acesso em: 02 mai. 2015.

2017. Cidades. Disponíveis em: <http://cidades.ibge.gov.br/xtras/home.php>. Acesso em: 2 jul, 2017.

2010. Mapa da população indígena no brasil. Disponível em: <http://indigenas.ibge.gov.br/mapas-indigenas-2>. Acesso em: 10 jan. 2017.

2017. Consumo intermediário, a preços correntes, das Atividades Características do Turismo, segundo as atividades - Brasil - 20032009.

em: 
$<$ http://www.ibge.gov.br/home/estatistica/economia/industria/economia_tur_200 32009/shtm>. Acesso em: 5 fev. 2017.

KOZLOWSKI S. 2004. Geodiversity: The concept and scope of geodiversity. Przeglad Geologiczny, 52 (8/2): 833 - 837.

LAGO, M.; ARRANZ, E.; ANDRÉS, J.A.; SORIA, A.R. \& GALÉ, C. 2001. Patrimonio Geológico: bases para su estudio y metodología. Zaragoza, Publicaciones del Consejo de Protección de la Naturaleza de Aragón. 107 p.

LETENSKI R., GUIMARÃES G. B., PIEKARZ G. F., MELO, M.S. 2009. Geoturismo no Parque Estadual de Vila Velha: nas trilhas da dissolução. Pesquisas em Turismo e Paisagens Cársticas, 2: 5-15.

LICCARDO, A., PIEKARZ, G., SALAMUNI, E. (2008) Geoturismo em Curitiba. Mineropar, Curitiba.

LICCARDO A., MANTESSO-NETO V., PIEKARZ G. 2012. Geoturismo Urbano - Educação e Cultura. Anuário Instituto de Geociências, 35(1):133-141.

MAZZUCATO, E. 2017. Estratégias de geoconservação no Parque Estadual da Serra do Mar - Núcleos Picinguaba e Caraguatatuba (SP). Programa de Pósgraduação em Mineralogia e Petrologia, Universidade de São Paulo, Dissertação de Mestrado, 320p.

MELÉNDEZ, G.; FERMELI, G.; ESCORIHUELA, E.; BASSO, A.; MOREIRA, J. 2011. What do we mean when we say Geotourism. In: International Congress Geotourism in action, Arouca Geopark, Portugal, p. 97-100.

MOREIRA, J. C. 2010. Geoturismo: Uma Abordagem Histórico-Conceitual. Pesquisas em Turismo e Paisagens Cársticas, 3(1). Campinas.

MOREIRA, J.C. 2011. Geoturismo e Interpretação Ambiental. Editora UEPG, $157 p$.

NASCIMENTO, M. A. L., RUCHKYS, U. A., MANTESSO-NETO, V. 2007. Geoturismo: Um Novo Segmento do Turismo no Brasil. Global Tourism. Periódico de turismo. 3(2).

NEWSOME, D., \& DOWLING, R. K. (Eds.). 2010. Geotourism: The Tourism of Geology and Landscape. Oxford: Goodfellow Publishers. 290p.

NIETO, L.M. 2001. Geodiversidad: propuesta de una definition integradora. Boletin geológico y minero, 112 (2): 3 - 12.

PERROTTA, M.M.; SALVADOR, E.D.; LOPES, R.C.; D'AGOSTINHO, L.Z.; PERUFFO, N.; GOMES, S.D.; SACHS, L.L.B.; MEIRA, V.T.; GARCIA, M.G.M. \& LACERDA FILHO, J.V. 2005. Mapa geológico do estado de São Paulo. São Paulo, Serviço Geológico do Brasil, escala 1:750.000. 
PETROBRAS. 2009. Sistema de Produção e Escoamento de Gás e Condensado no Campo de Mexilhão, Bacia de Santos. Programa da Ação Participativa para a Pesca Artesanal --Comunidade do Camaroeiro, Município de Caraguatatuba. Relatório do DRP e Banco de Projetos. Caraguatatuba: Petrobras.

PIEKARZ, G. E LICCARDO, A. 2007. Turismo Geológico na rota dos tropeiros. Global Tourism. 3(2). Novembro de 2007. ISSN: 1508-558X.

PEIKARZ, G. F. 2011. Geoturismo no Karst. Mineropar, Curitiba, 121p.

PINTO A. 2015. Geodiversidade e Patrimônio Geológico de Salvador: uma diretriz para a geoconservação e a educação em geociências. Tese (Doutorado), Instituto de Geociências, Universidade Federal da Bahia, Salvador, p. 332.

PROCHOROFF, R. 2014. Patrimônio geológico de llhabela-SP: estratégias de geoconservação. Programa de Pós-graduação em Mineralogia e Petrologia, Universidade de São Paulo, Dissertação de Mestrado, 176p.

REVERTE, F.C. 2014. Avaliação da Geodiversidade em São Sebastião - SP, com Patrimônio Geológico. Programa de Pós-graduação em Mineralogia e Petrologia, Universidade de São Paulo, Dissertação de Mestrado, 208p.

ROCHA, A.J.D.; LIMA, E.; SCHOBBENHAUS, C. 2016. Aplicativo Geossit Nova Versão. IN: 48 CONGRESSO BRASILEIRO DE GEOLOGIA. Anais do 48 Congresso Brasileiro de Geologia. Porto Alegre - RS.

SANTOS, P.L.A. 2014. Patrimônio Geológico em Áreas de Proteção Ambiental: Ubatuba - SP. Programa de Pós-graduação em Mineralogia e Petrologia, Universidade de São Paulo, Dissertação de Mestrado, 207p.

SÃO PAULO (Estado). Secretaria do Meio Ambiente. 2005. Litoral Norte. Coordenadoria de Planejamento Ambiental Estratégico e Educação Ambiental, São Paulo: SMA/CPLEA, p.11.

SÃO PAULO (Estado). Secretaria do Meio Ambiente. Macrozoneamento do litoral norte: plano de gerenciamento costeiro. São Paulo: Secretaria de Meio Ambiente/Coordenadoria de Planejamento Ambiental, 1996.

SCIFONI, S. 2006. A construção do patrimônio natural. Programa de Pósgraduação em Geografia Humana, Faculdade de Filosofia, Letras e Ciências Humanas, Universidade de São Paulo. Tese de doutorado. 294p.

SEADE, 2011. Informações dos Municípios Paulistas - IMIP. Fundação Sistema Educaional Análise de Dados - SEADE. Disponível em: $<$ http://produtos.seade.gov.br/produtos/imp/> acessado em Maio de 2015. 
SERRANO, E. \& RUIZ-FLAÑO, P. 2007. Geodiversity: a theoretical and applied concept. Geographica Helvetica, 62 (3): 140 - 147.

SHARPLES, C. 2002. Concepts and principles of geoconservation. Tasmanian Parks \& wildlife. Disponível em: $<$ https://www.researchgate.net/publication/266021113_Concepts_and_principle s_of_geoconservation > acessado em Junho de 2017.

STANLEY, M. 2001. Geodiversity. Earth Heritage, 14: 15 - 18.

STERN A.G., RICCOMINI C., FAMBRINI G.L., CHAMANI M.A.C. 2006. Roteiro geológico pelos edifícios e monumentos históricos do centro da cidade de São Paulo. Revista Brasileira de Geociências 36(4):704-711.

TEIXEIRA, L.R., LEGASPE, L.B.C., MILANELLI, J.C.C. 2011. Gestão Integrada de Grandes Empreendimentos: O Desafio do Litoral Norte do Estado de São Paulo. V Simpósio Brasileiro de Oceanografia. Oceanografia e Políticas Públicas. Santos - SP, 2011.

WIMBLEDON, W.A.P.; ANDERSEN, S.; CLEAL, C.J.; COWIE, J.W.; ERIKSTAD, L.; GONGGRIJP, G.P.; JOHANSSON, C.E.; KARIS, L.O. \& SUOMINEN, V. 1997. Geological World Heritage: GEOSITES - a global site inventory to enable prioritisation for conservation. In: SYMPOSIUM OF THE EUROPEAN ASSOCIATION FOR THE CONSERVATION OF THE GEOLOGICAL HERITAGE, 2, Trento, 1997. Memoire Del Servizio Geologico d'Italia, Trento, p. 45-60. 
ANEXOS

A - INVENTÁRIO E QUANTIFICAÇÃO DO PATRIMÔNIO GEOLÓGICO DO MUNICÍPIO DE CARAGUATATUBA, SÃO PAULO, BRASIL

B - MÉTODO DE SELEÇÃO E PROPOSTAS DE USO dOS SíTIOS DA GEODIVERSIDADE: EXEMPLO DO LITORAL NORTE DO ESTADO DE SÃO PAULO, BRASIL

C - INVENTÁRIO GEOLÓGICO DO PATRIMÔNIO CONSTRUÍDO NO LITORAL NORTE DO ESTADO DE SÃO PAULO, BRASIL 


\begin{abstract}
ANEXO A - INVENTÁRIO E QUANTIFICAÇÃO DO PATRIMÔNIO GEOLÓGICO DO MUNICÍPIO DE CARAGUATATUBA, SÃO PAULO, BRASIL
\end{abstract}

\author{
ARRUDA, K.E.C.; GARCIA, M.G.M.; DEL LAMA, E.A. 2017. Inventário e \\ Avaliação Quantitativa do Patrimônio Geológico do município de \\ Caraguatatuba, São Paulo. Geociências, UNESP, São Paulo, 36 (3): 447 - \\ 462.
}

\title{
INVENTÁRIO E QUANTIFICAÇÃO DO PATRIMÔNIO GEOLÓGICO DO MUNICÍPIO DE CARAGUATATUBA, SÃO PAULO
}

\author{
Karlla Emmanuelle Cunha Arruda'; Maria da Glória Motta Garcia1; Eliane Aparecida Del \\ Lama $^{1}$
${ }^{1}$ Universidade de São Paulo, Instituto de Geociências, Núcleo de Apoio à Pesquisa em Patrimônio 080 - Butantã - São Paulo, SP, São Paulo - SP. E-mails: karllaarruda@usp.br; mgmg@usp.br; edellama@usp.br. \\ Geológico e Geoturismo (GeoHereditas), Rua do Lago, 562 - Térreo - Bloco D - Sala 11 CEP: 05508-
}

Resumo - O município de Caraguatatuba apresenta uma rica geodiversidade relacionada à amalgamação e fragmentação do Supercontinente Gondwana. A ausência de estudos geológicos detalhados, associada à falta de informação e à ameaça da urbanização desordenada justifica a necessidade de um inventário do patrimônio geológico do município. A partir de pesquisa bibliográfica e trabalhos de campo foram definidos sete geossítios: Praia Brava, Megaboudin da Lagoa Azul, Milonitos da Tabatinga-Ilha do Tamanduá, Milonitos e Cataclasitos da Estrada da Petrobras, Morro do Santo Antônio, Geoformas de Caraguatatuba e Registros da Catástrofe. A quantificação forneceu as pontuações para valor científico, potencial para uso educacional e turístico e para risco de degradação. A partir dos resultados, conclui-se que os geossítios com elementos geomorfológicos apresentaram pontuações mais altas para pontencial de uso educacional e turístico. O geossítio Morro do Santo Antônio obteve a maior pontuação em valor científico e risco de degradação. Os dados obtidos neste trabalho são parte de um projeto maior que abrange o inventário do patrimônio geológico da região costeira do estado de São Paulo e base de um projeto que visa aplicar o geoturismo no litoral norte. Os dados serão utilizados como ferramenta de auxílio para gestão territorial e implementação de estratégias de geoconservação.

Palavras-Chave: Caraguatatuba; Inventário; Patrimônio Geológico; Quantificação.

\section{INVENTORY AND QUANTIFICATION OF GEOLOGICAL HERITAGE OF THE TOWN OF CARAGUATATUBA, SÃO PAULO}

\begin{abstract}
The town of Caraguatatuba presents a rich geodiversity related to the amalgamation and fragmentation of the Gondwana Supercontinent. The absence of detailed geological studies, combined with lack of information and the threat of chaotic urbanization, leads to the necessity of a geological heritage inventory. Based on literature review and field work, seven geosites have been defined: Brava Beach, Lagoa Azul Megaboudin, Tabatinga-Tamanduá Island Mylonites, Petrobras Road Mylonites and Cataclasites, Santo Antonio Hill, Caraguatatuba Geoforms and Registers of the
\end{abstract}


Catastrophe. Also, a quantification analysis has been carried out, from which were obtained: scientific value, potential for educational and touristic use, and risk of degradation. From the results, it is concluded that the geosites that feature geomorphological elements achieved higher scores for potential educational and touristic use. The Santo Antonio Hill geosite achieved the highest scores in scientific value and risk of degradation. The data obtained in this study are part of a larger project that covers the geological heritage inventory of the coastal region of São Paulo State, and also are the base of a project that aims the development of geotourism on the northern coast of São Paulo State. The data will be used as tools for territorial management and implementation of geoconservation strategies.

Keywords: Caraguatatuba; Inventory; Geological Heritage; Quantification.

\section{INTRODUÇÃO}

O levantamento e catalogação do patrimônio geológico de um determinado local é o primeiro passo para se estabelecer prioridades de gestão. Por meio do inventário e da quantificação o geossítio pode ser inserido no registro dos locais que possuem relevância científica para a história geológica de uma determinada região e que merecem ser protegidos e valorizados.

Para realizar uma catalogação sistemática do patrimônio geológico são necessários métodos de inventariação adequados e padronizados. Na literatura existem algumas tentativas de padronização de inventários (Alexandrowicz \& Kozlowski, 1999; Brilha, 2005; Bruschi, 2007; García-Cortés \& Carcavilla Urquí 2009; Lima et al., 2010; Wimbledon, 2011; Gray, 2013), a maior parte deles voltado ao inventário de áreas extensas, em que os trabalhos de campo têm como objetivo visitar pontos préselecionados. No caso da área em questão, o método utilizado foi o de áreas restritas, no qual, além da visita a sítios potenciais, as etapas de campo incluem técnicas de mapeamento geológico sistemático.

Um dos principais objetivos dos inventários do patrimônio geológico é identificar locais com relevância científica (além de educativa e turística) que possam ser incluídos em políticas públicas envolvendo gestão territorial e benefício da população. No caso do município estudado, situado no litoral norte do estado de São Paulo, este levantamento se justifica pela relevância geológica e pela ameaça advinda do crescimento urbano desordenado, do turismo de massa e da instalação de centros industriais. O estudo faz parte de um projeto maior, que tem como objetivo realizar o inventário da região costeira do estado de São Paulo (Garcia, 2012; Garcia et al., 2014). 
O município de Caraguatatuba, foco deste trabalho, abrange uma área de $485 \mathrm{~km}^{2} \mathrm{e}$ possui uma rica geodiversidade, com características geológicas, geomorfológicas e estruturais de relevante valor científico e atrativa para muitos turistas. Porém pouca informação geológica é dada aos habitantes locais e aos visitantes.

Neste sentido, o presente trabalho faz parte de uma tese de doutorado que tem como objetivo propor um plano geoturístico para o litoral norte do estado de São Paulo, a partir de dados obtidos por inventários anteriores nos municípios da região (Prochoroff, 2014; Reverte, 2014; Santos, 2014). No total, sete geossítios foram inventariados de acordo com seu valor científico, para os quais se procedeu e quantificação de acordo com Brilha (2016). Os dados obtidos foram utilizados para avaliar o potencial para uso educacional e para uso turístico e para estimar o risco de degradação e necessidade de proteção dos geossítios.

\section{ÁREA DE ESTUDO}

\section{CONTEXTO GEOGRÁFICO}

A cidade de Caraguatatuba é o ponto central da região do litoral norte do estado de São Paulo, abrangendo uma área de 485,097 $\mathrm{Km}^{2}$ e distante $180 \mathrm{~km}$ da capital do estado. Está geomorfologicamente inserida na planície costeira, entre o Oceano Atlântico e as escarpas da Serra do Mar, sendo banhada pelos Rios Juqueriquerê, Massaguaçu, Santo Antônio, Guaxinduba, Camburu e seus afluentes.

O clima é o subtropical úmido com intensas chuvas de verão, que quando associadas aos solos argilosos - Cambissolos - das escarpas da Serra do Mar provocam escorregamentos de massa.

O município abrange o Núcleo Caraguatatuba (57.604,07 ha) do Parque Estadual da Serra do Mar (PESM), criado pelo Decreto n 10.251 de 31 de agosto de 1977 (SMA/IF, 1977), abrigando uma área de preservação de um dos maiores remanescentes de Floresta Atlântica do país.

Os geossítios inventariados estão distribuídos principalmente na porção central do município, nos bairros Rio do Ouro, Sumaré, Martin de Sá e Capricórnio; e dois nas extremidades sudeste e nordeste (Figura 1). 


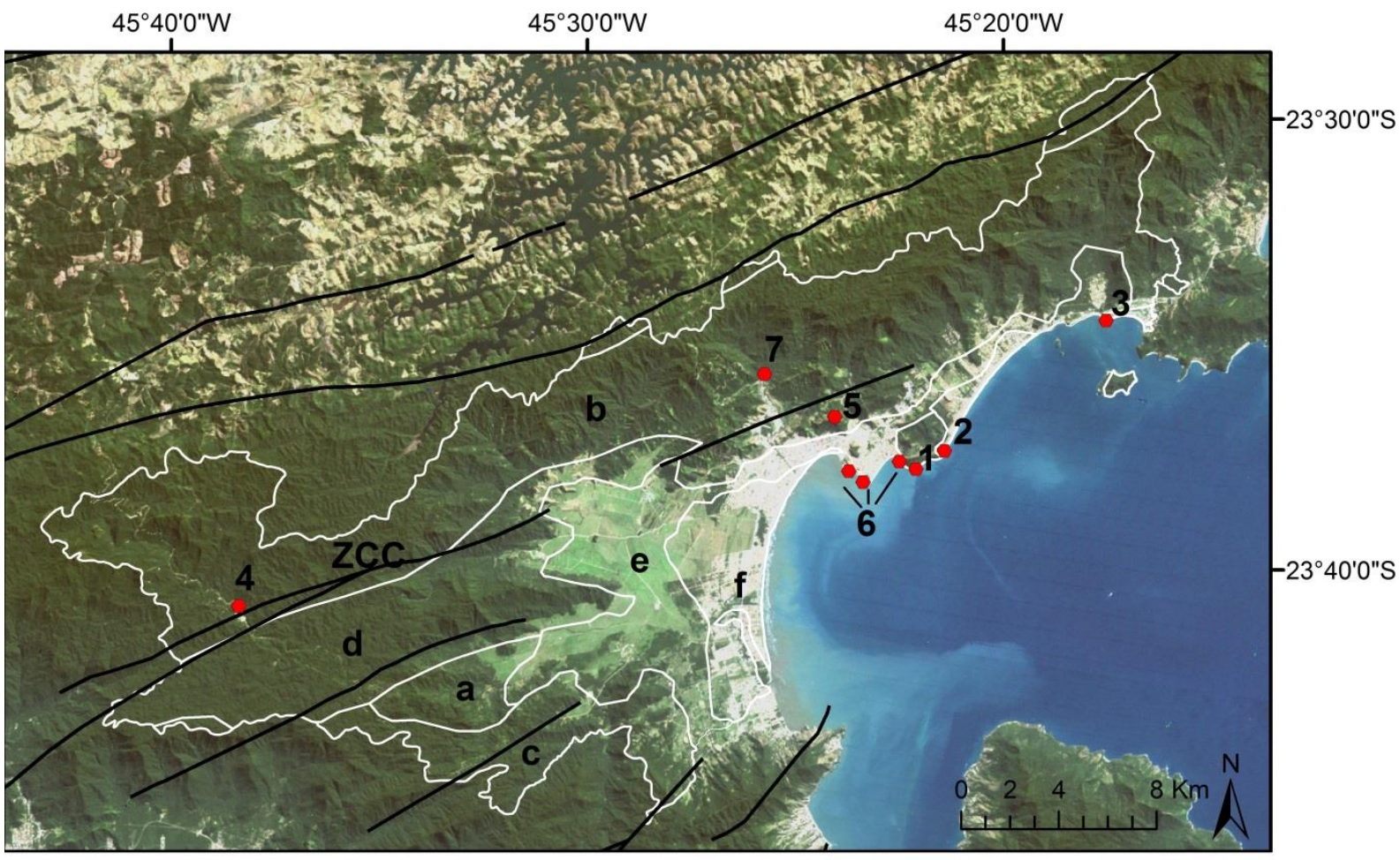

\section{- Geossítios \\ Limites litológicos \\ Estruturas geológicas}

Figura 1. Localização dos Geossítios em Caraguatatuba: 1 - Praia Brava; 2 - Megaboudin da Lagoa Azul; 3 - Milonitos da Tabatinga-Ilha do Tamanduá; 4 - Milonitos e Cataclasitos da Estrada da Petrobras; 5 - Morro do Santo Antônio; 6 - Geoformas de Caraguatatuba; 7 Registro da Catástrofe. Compartimentações litológicas (Perrota et al, 2005): a - Suíte Máfica do Complexo Bairro do Marisco; b - Granitos foliados calcialcalinos, Pico do Papagaio; c Unidade granito-gnáissica migmatítica; d - Unidade de gnaisses peraluminosos; e -Depósitos detríticos; f - Depósitos litorâneos; ZCC - Zona de Cisalhamento Camburu.

\section{CONTEXTO GEOLÓGICO}

A evolução geológica da região está associada às etapas de amalgamação, desenvolvimento e fragmentação do Supercontinente Gondwana Ocidental, relacionada à formação da Serra do Mar e à abertura do Oceano Atlântico Sul. O município de Caraguatatuba é geologicamente composto por rochas do Terreno Serra do Mar, da Província Mantiqueira (Almeida et al, 1977) e por sedimentos quaternários.

O embasamento cristalino é constituído por rochas do Complexo Costeiro pertencentes às seguintes unidades: i) Unidade Granito Gnáissica migmatítica, composta por hornblenda-biotita gnaisse granitoide porfiroide e augen gnaisse; ii) Unidade de gnaisses peraluminosos, constituídos por gnaisse kinzigítico, rocha calcissilicática e 
anfibolitos; iii) Unidade de granitos foliados calcialcalinos do Pico do Papagaio, presentes em toda a área composta pela Serra do Mar no município; e iv) Suíte Máfica Bairro do Marisco (Perrota et al., 2005).

Na porção sudoeste do município está a Zona de Cisalhamento Camburu, uma faixa de rochas miloníticas predominantemente quartzo feldspáticas (Melo \& Pires Neto, 1977). Caracteriza-se como uma zona de cisalhamento dúctil com movimento transcorrente destral com direção NE-SW (Campanha \& Ens, 1993; Mora et al., 2013).

Na planície estão os depósitos quaternários, constituídos por sedimentos detríticos: areia, silte, argila e cascalhos; e sedimentos litorâneos: areia, silte e argila. Segundo Souza (1990), esses depósitos podem ser classificados em 4 tipos: de tálus, fluviais, marinhos, e mistos. O nível marinho nessa planície já atingiu os sopés das encostas da Serra do Mar (Suguio \& Martin, 1978), depositando areias marinhas, que foram posteriormente recobertas por depósitos colúvio-aluviais (Cruz, 1974).

\section{CONTEXTO SOCIAL}

O Município de Caraguatatuba possui 111,524 habitantes, e uma densidade populacional de 229,9 hab./Km² (IBGE, 2014). A mancha urbana cresceu a partir do centro e, segundo Padgurschi (2000) o fenômeno está ligado ao desenvolvimento do turismo na região, que começou a crescer na década de 1950, com a abertura da rodovia ligando São Sebastião-Caraguatatuba-Ubatuba. Porém, apenas na década de 1970 teve início um crescimento populacional mais acelerado no município.

Na década de 1980 houve um crescimento populacional ainda maior, já como segunda residência para veraneio (Tabela 1). Nota-se, nesse período, que núcleos antigos de pescadores começaram a ser ocupados pela população de outros municípios, resultando em uma marginalização das comunidades tradicionais.

Tabela 1. Residências secundárias no total de domicílios por município no litoral norte de São Paulo. Fonte: IBGE (2007).

\begin{tabular}{|c|c|c|c|c|}
\hline Municípios & 1980 & 1991 & 2000 & 2007 \\
\hline Caraguatatuba & $42,42 \%$ & $50,84 \%$ & $51,32 \%$ & $52,85 \%$ \\
\hline Ilhabela & $29,25 \%$ & $36,68 \%$ & $37,31 \%$ & $37,90 \%$ \\
\hline São Sebastião & $33,50 \%$ & $45,70 \%$ & $48,62 \%$ & $51,69 \%$ \\
\hline Ubatuba & $41,60 \%$ & $49,46 \%$ & $53,35 \%$ & $57,32 \%$ \\
\hline
\end{tabular}


Na década de 90, iniciam-se as ocupações desordenadas de encostas de morros e de áreas ribeirinhas, produzindo assentamentos precários em áreas de riscos. A partir deste momento a densidade demográfica ultrapassou o grau de urbanização no município. A década de 2000 foi marcada por uma expansão urbana menos acelerada, junto aos locais já urbanizados em períodos anteriores (Instituto Pólis, 2012).

O Produto Interno Bruto (PIB) per capita no município é inferior à média estadual (Tabela 2), porém o Índice de Desenvolvimento Humano Municipal (IDHM), é considerado alto, colocado no $169^{\circ}$ lugar no ranking dos municipios com maior IDHM do estado de São Paulo.

Tabela 2. Produto Interno Bruto (PIB) per capita e Índice de Desenvolvimento Humano Municipal (IDHM) em Caraguatatuba e no estado de São Paulo. Fonte: IBGE (2014).

\begin{tabular}{|c|c|c|c|c|}
\hline Localidade & $\begin{array}{c}\text { PIB per Capita } \\
(2000)(\mathrm{R} \$)\end{array}$ & $\begin{array}{c}\text { PIB per Capita } \\
(2010)(\mathrm{R} \$)\end{array}$ & $\begin{array}{c}\text { IDHM } \\
(2000)\end{array}$ & $\begin{array}{c}\text { IDHM } \\
(2010)\end{array}$ \\
\hline Caraguatatuba & $5.365,41$ & $13.355,66$ & 0,685 & 0,759 \\
\hline Estado de São Paulo & $11.471,76$ & $30.264,06$ & 0,702 & 0,783 \\
\hline
\end{tabular}

\section{MATERIAIS E MÉTODOS}

A etapa inicial do trabalho consistiu na coleta de dados na literatura e na consulta a pesquisadores, a fim de identificar sítios potenciais que pudessem ser incluídos no inventário. Com base nesta pesquisa inicial, foram realizados trabalhos de campo com o objetivo de avaliar os sítios pré-selecionados e investigar outros locais por meio do acesso a costões rochosos e trilhas.

A base cartográfica utilizada foi o Mapa Geológico do estado de São Paulo (Perrota et al., 2005). A partir da descrição dos sítios de maior importância geológica no munícipio, foram selecionados sete geossítios que respondem aos critérios de relevância científica: Representatividade, Integridade, Raridade e Conhecimento Geológico.

A tipologia espacial dos geossítios foi definida a partir do método descrito em Fuertes-Gutiérrez \& Fernández-Martínez (2010), que definem cinco tipos de geossítios de acordo com seu tamanho e extensão: Pontual, Seção, Área, Mirante e Área Complexa. Os elementos geológicos dos geossítios foram descritos com base nas opções de tipologia existentes no formulário de propostas da Comissão Brasileira de Sítios Geológicos e Paleontológicos - SIGEP. 
A quantificação dos geossítios foi realizada utilizando-se o método descrito em Brilha (2016), em que são pontuados o Valor Científico (VC) (Tabela 3), os potenciais para uso educacional $(\mathrm{Pe})$ e para uso turístico $(\mathrm{Pt})$ (Tabela 4) e o Risco de Degradação (Rd) (Tabela 5), e calculados os seus valores de acordo com o peso estabelecido em cada critério.

Tabela 3. Critérios e parâmetros para a quantificação do Valor Científico dos geossítios (Brilha, 2016).

\begin{tabular}{|c|c|}
\hline \multicolumn{2}{|r|}{ Valor Científico (VC) } \\
\hline Critérios (peso \%) & Pontos/Parâmetros \\
\hline \multirow{3}{*}{$\begin{array}{l}\text { A - } \\
\text { Representatividade } \\
(30 \%)\end{array}$} & $\begin{array}{l}4 \text { - O geossítio é o melhor exemplo na área de estudo para ilustrar elementos ou processos, } \\
\text { relacionado com a temática geológica em consideração (quando aplicável). }\end{array}$ \\
\hline & $\begin{array}{l}2 \text { - O geossítio é um bom exemplo na área de estudo para ilustrar elementos ou processos, } \\
\text { relacionado com a temática geológica em consideração (quando aplicável). }\end{array}$ \\
\hline & $\begin{array}{l}1 \text { - o geossítio ilustra razoavelmente elementos ou processos na área de estudo, } \\
\text { relacionado com a temática geológica em consideração (quando aplicável). }\end{array}$ \\
\hline \multirow[t]{3}{*}{ B - Local-tipo (20\%) } & $\begin{array}{l}\text { 4 - O geossítio é reconhecido como um GSSP ou ASSP pela IUGS ou é um sítio de referência } \\
\text { no IMA. }\end{array}$ \\
\hline & $\begin{array}{l}2 \text { - O geossítio é utilizado pela ciência internacional, diretamente relacionado com a } \\
\text { temática geológica em consideração (quando aplicável). }\end{array}$ \\
\hline & $\begin{array}{l}1 \text { - O geossítio é usado pela ciência nacional, diretamente relacionado com a temática } \\
\text { geológica em consideração (quando aplicável). }\end{array}$ \\
\hline \multirow[t]{3}{*}{$\begin{array}{l}\text { C-Conhecimento } \\
\text { Científico (5\%) }\end{array}$} & $\begin{array}{l}4 \text { - Existem artigos em jornais científicos internacionais sobre esse geossítio, diretamente } \\
\text { relacionado com a temática geológica em consideração (quando aplicável). }\end{array}$ \\
\hline & $\begin{array}{l}2 \text { - Existem artigos em publicações científicas nacionais sobre esse geossítio, diretamente } \\
\text { relacionado com a temática geológica em consideração (quando aplicável). }\end{array}$ \\
\hline & $\begin{array}{l}1 \text { - Existem resumos apresentados em eventos científicos internacionais sobre esse } \\
\text { geossítio, diretamente relacionado com a temática geológica em consideração (quando } \\
\text { aplicável). }\end{array}$ \\
\hline \multirow[t]{3}{*}{$\begin{array}{l}\text { D - Integridade } \\
(15 \%)\end{array}$} & $\begin{array}{l}4 \text { - Os principais elementos geológicos (relacionado com a temática geológica em } \\
\text { consideração, quando aplicável) estão muito bem preservados. }\end{array}$ \\
\hline & $\begin{array}{l}2 \text { - Geossítio não tão bem preservado, mas os principais elementos geológicos (relacionado } \\
\text { com a temática geológica em consideração, quando aplicável) ainda estão preservados. }\end{array}$ \\
\hline & $\begin{array}{l}1 \text { - Geossítio com problemas de preservação e com os principais elementos geológicos } \\
\text { (relacionado com a temática geológica em consideração, quando aplicável) muito alterados } \\
\text { ou modificados. }\end{array}$ \\
\hline \multirow[t]{3}{*}{$\begin{array}{l}\text { E - Diversidade } \\
\text { Geológica (5\%) }\end{array}$} & $\begin{array}{l}4 \text { - Geossítio com mais de três tipos de características geológicas distintas com relevância } \\
\text { científica. }\end{array}$ \\
\hline & 2 - Geossítio com três tipos de características geológicas distintas com relevância científica. \\
\hline & 1-Geossítio com dois tipos de características geológicas distintas com relevância científica. \\
\hline \multirow[t]{3}{*}{ F-Raridade (15\%) } & $\begin{array}{l}\text { 4- O geossítio é a única ocorrência desse tipo na área de estudo (representando a temática } \\
\text { geológica em consideração, quando aplicável). }\end{array}$ \\
\hline & $\begin{array}{l}2 \text { - Na área de estudo existem dois ou três exemplos de geossítios similiares (representando } \\
\text { a temática geológica em consideração, quando aplicável). }\end{array}$ \\
\hline & $\begin{array}{l}1 \text { - Na área de estudo, existem quatro ou cinco exemplos de geossítios similares } \\
\text { (representando a temática geológica em consideração, quando aplicável). }\end{array}$ \\
\hline \multirow[t]{3}{*}{$\begin{array}{l}\text { G - Limitações de } \\
\text { Uso }(10 \%)\end{array}$} & $\begin{array}{l}4 \text { - O geossítio não possui limitações (permissões legais, barreiras físicas, ...) para coleta de } \\
\text { amostras ou campo. }\end{array}$ \\
\hline & 2-É possível coletar amostras e fazer campo depois de ultrapassar as limitações. \\
\hline & $\begin{array}{l}1 \text { - Campo e amostragens são muito difíceis de serem realizados devido a dificuldades de } \\
\text { limitações (permissões legais, barreiras físicas, ...). }\end{array}$ \\
\hline
\end{tabular}


Tabela 4. Critérios e parâmetros para a quantificação do Potencial de uso educacional e turístico dos geossítios (Brilha, 2016).

\begin{tabular}{|c|c|}
\hline \multicolumn{2}{|r|}{ Potencial Para Uso Educacional (Pe) e Turístico (Pt) } \\
\hline $\begin{array}{l}\text { Critérios (pesos Pe } \\
\text { e Pt) }\end{array}$ & Pontos/Parâmetros \\
\hline \multirow[t]{4}{*}{$\begin{array}{l}\text { A - Vulnerabilidade } \\
\text { (Pe-10/Pt-10) }\end{array}$} & $\begin{array}{l}\text { 4- Os elementos geológicos do geossítio não apresentam possibilidade de deterioração } \\
\text { pela atividade antrópica. }\end{array}$ \\
\hline & $\begin{array}{l}3 \text { - Existe a possibilidade de deterioração dos elementos geológicos secundários pela } \\
\text { atividade antrópica. }\end{array}$ \\
\hline & $\begin{array}{l}2 \text { - Existe a possibilidade de deterioração dos principais elementos geológicos pela atividade } \\
\text { antrópica. }\end{array}$ \\
\hline & $\begin{array}{l}\text { 1- Existe a possibilidade de deterioração de todos os elementos geológicos pela atividade } \\
\text { antrópica. }\end{array}$ \\
\hline \multirow[t]{4}{*}{$\begin{array}{l}\text { B-Acessibilidade } \\
\text { (Pe-10/Pt-10) }\end{array}$} & $\begin{array}{l}\text { 4-Sítio localizado a menos de } 100 \mathrm{~m} \text { de uma estrada pavimentada e com estacionamento } \\
\text { para ônibus. }\end{array}$ \\
\hline & 3-Sítio localizado a menos de $500 \mathrm{~m}$ de uma estrada pavimentada. \\
\hline & 2 - Sítio acessível por ônibus, mas através de estrada de terra. \\
\hline & $\begin{array}{l}1 \text { - Sítio sem acesso direto pela estrada mas localizado a menos de } 1 \mathrm{Km} \text { de uma estrada } \\
\text { acessível por ônibus. }\end{array}$ \\
\hline \multirow{4}{*}{$\begin{array}{l}\text { C- Limitações de } \\
\text { Uso } \\
\text { (Pe-5/Pt-5) }\end{array}$} & 4-O sítio não possui limitações para ser usado por estudantes e turistas. \\
\hline & 3-O sítio pode ser usado por estudantes e turistas, mas apenas ocasionalmente. \\
\hline & $\begin{array}{l}\text { 2- O sítio pode ser usado por estudantes e turistas, mas apenas após ultrapassadas as } \\
\text { limitações (legal, permissões, física, marés, inundações,...). }\end{array}$ \\
\hline & $\begin{array}{l}\text { 1- O uso por estudantes e turistas é muito difícil de ser realizado devido às limitações } \\
\text { físicas (legal, permissões, física, marés, inundações,...). }\end{array}$ \\
\hline \multirow[t]{4}{*}{$\begin{array}{l}\text { D - Segurança } \\
\text { (Pe-10/Pt-10) }\end{array}$} & $\begin{array}{l}\text { 4-Sítio com facilidades de segurança (cercas, escadas, corrimãos, etc.), cobertura para } \\
\text { telefone móvel e localizado a menos de } 5 \mathrm{Km} \text { de serviços de emergência. }\end{array}$ \\
\hline & $\begin{array}{l}\text { 3- Sítio com facilidades de segurança (cercas, escadas, corrimãos, etc.), cobertura para } \\
\text { telefone móvel e localizada a menos de } 25 \mathrm{Km} \text { de serviços de emergência. }\end{array}$ \\
\hline & $\begin{array}{l}\text { 2-Sítio sem facilidades de segurança mas com cobertura para tefone móvel e localizado a } \\
\text { menos de } 50 \mathrm{Km} \text { de serviços de emergência. }\end{array}$ \\
\hline & $\begin{array}{l}1 \text { - Sítio sem facilidades de segurança, sem cobertura para telefone móvel e localizado a } \\
\text { mais de } 50 \mathrm{Km} \text { de serviços de emergência. }\end{array}$ \\
\hline \multirow{4}{*}{$\begin{array}{l}\text { E- Logística } \\
\text { (Pe-5/Pt-5) }\end{array}$} & 4-Hospedagem e restaurantes para grupos de 50 pessoas a menos de $15 \mathrm{Km}$ do sítio. \\
\hline & 3 - Hospedagem e restaurantes para grupos de 50 pessoas a menos de $50 \mathrm{Km}$ do sítio. \\
\hline & 2 - Hospedagem e restaurantes para grupos de 50 pessoas a menos de $100 \mathrm{Km}$ do sítio. \\
\hline & $\begin{array}{l}\text { 1- Hospedagem e restaurantes para grupos com menos de } 25 \text { pessoas e a menos de } 50 \mathrm{Km} \\
\text { do sítio. }\end{array}$ \\
\hline \multirow{4}{*}{$\begin{array}{l}\text { F-Densidade da } \\
\text { população } \\
\text { (Pe-5/Pt-5) }\end{array}$} & 4-Sítio localizado em um município com mais de 1000 habitantes $/ \mathrm{km}^{2}$. \\
\hline & 3 - Sítio localizado em um município com 250-1000 habitantes/km². \\
\hline & 2 - Sítio localizado em um município com 100-250 habitantes/km². \\
\hline & 1 - Sítio localizado em um município com menos de 100 habitantes $/ \mathrm{km}^{2}$. \\
\hline \multirow{4}{*}{$\begin{array}{l}\text { G - Associação com } \\
\text { outros valores } \\
\text { (Pe-5/Pt-5) }\end{array}$} & 4-Ocorrência de vários valores ecológicos e culturais a menos de $5 \mathrm{~km}$ do sítio. \\
\hline & 3- Ocorrência de vários valores ecológicos e culturais a menos de 10 km do sítio. \\
\hline & 2 - Ocorrência de um valor ecológico e um valor cultural a menos de $10 \mathrm{~km}$ do sítio. \\
\hline & 1- Ocorrência de um valor ecológico ou cultural a menos de $10 \mathrm{~km}$ do sítio. \\
\hline \multirow{4}{*}{$\begin{array}{l}\text { H-Cenário } \\
\text { (Pe-5/Pt-15) }\end{array}$} & 4-Sítio frequentemente usado como um destino turístico em campanhas nacionais. \\
\hline & 3-Sítio ocasionalmente usado como destino turístico em campanhas nacionais. \\
\hline & 2 - Sítio frequentemente usado como destino turístico em campanhas locais. \\
\hline & 1-Sítio ocasionalmente usado como destino turístico em campanhas locais. \\
\hline \multirow[t]{4}{*}{$\begin{array}{l}\text { I-Uniquissidade } \\
\text { (Pe-5/Pt-10) }\end{array}$} & $\begin{array}{l}\text { 4- O sítio apresenta características únicas e incomuns considerando seu país e países } \\
\text { vizinhos. }\end{array}$ \\
\hline & 3-O sítio apresenta características únicas e incomuns em seu país. \\
\hline & $\begin{array}{l}2 \text { - O sítio apresenta características comuns na região mas incomuns em outras regiões do } \\
\text { país. }\end{array}$ \\
\hline & 1-O sítio apresenta características bastante comuns em todo país. \\
\hline \multirow{3}{*}{$\begin{array}{l}\text { J - Condições } \\
\text { observacionais } \\
\text { (Pe-10/Pt-5) }\end{array}$} & 4-Todos os elementos geológicos são observados em boas condições. \\
\hline & $\begin{array}{l}3 \text { - Existem alguns obstáculos que tornam difícil a observação de alguns elementos } \\
\text { geológicos. }\end{array}$ \\
\hline & 2 - Existem alguns obstáculos que tornam difícil a observação dos principais elementos \\
\hline
\end{tabular}




\begin{tabular}{|c|c|}
\hline \multicolumn{2}{|c|}{\begin{tabular}{l|l} 
geológicos. \\
\cline { 2 - 2 }
\end{tabular}} \\
\hline & $\begin{array}{l}1 \text { - Existem alguns obstáculos que quase obstruem a observação dos principais elementos } \\
\text { geológicos. }\end{array}$ \\
\hline \multicolumn{2}{|r|}{ Potencial Para Uso Educacional (Pe) } \\
\hline \multirow{4}{*}{$\begin{array}{l}\text { Ke-Potencial } \\
\text { didático } \\
\text { (20) }\end{array}$} & 4-O sítio apresenta elementos geológicos que são ensinados em todos os níveis escolares. \\
\hline & $\begin{array}{l}3 \text { - O sítio apresenta elementos geológicos que são ensinados em escolas do ensino } \\
\text { fundamental. }\end{array}$ \\
\hline & 2-O sítio apresenta elementos geológicos que são ensinados no nível médio. \\
\hline & 1- O sítio apresenta elementos geológicos que são ensinados na universidade. \\
\hline \multirow{4}{*}{$\begin{array}{l}\text { Le - } \\
\text { Diversidade } \\
\text { geológica } \\
\text { (10) }\end{array}$} & $\begin{array}{l}4 \text { pontos - Mais de } 3 \text { tipos de elementos da geodiversidade ocorrem no sítio (mineralógico, } \\
\text { paleontológico, geomorfológico, etc.). }\end{array}$ \\
\hline & 3 - Existem 3 tipos de elementos da geodiversidade no sítio. \\
\hline & 2 - Existem 2 tipos de elementos da geodiversidade no sítio. \\
\hline & 1 - Existe apenas um tipo de elemento da geodiversidade no sítio. \\
\hline \multicolumn{2}{|r|}{ Potencial Para Uso Turístico (Pt) } \\
\hline \multirow{4}{*}{$\begin{array}{l}\text { Kt - Potencial } \\
\text { interpretativo } \\
\text { (10) }\end{array}$} & $\begin{array}{l}\text { 4-O sítio apresenta elementos geológicos de uma forma muito clara e expressiva para todos os } \\
\text { tipos de público. }\end{array}$ \\
\hline & $\begin{array}{l}3 \text { - O público necessita de alguma base geológica para entender os elementos geológicos do } \\
\text { sítio. }\end{array}$ \\
\hline & $\begin{array}{l}2 \text { - O público necessita ter uma base geológica forte para entender os elementos geológicos do } \\
\text { sítio. }\end{array}$ \\
\hline & 1-O sítio apresenta elementos geológicos compreendidos apenas por especialistas. \\
\hline \multirow{4}{*}{$\begin{array}{l}\text { Lt - Nível } \\
\text { econômico } \\
\text { (5) }\end{array}$} & $\begin{array}{l}\text { 4- O sítio está localizado em um município com uma renda familiar acima do dobro da média } \\
\text { nacional. }\end{array}$ \\
\hline & $\begin{array}{l}3 \text { - O sítio está localizado em um município com uma renda familiar mais alta do que a média } \\
\text { nacional. }\end{array}$ \\
\hline & 2-O sítio está localizado em um município com uma renda familiar similar a média nacional. \\
\hline & 1- O sítio está localizado em um município com uma renda familiar abaixo da média nacional. \\
\hline \multirow{4}{*}{$\begin{array}{l}\text { Mt - } \\
\text { Proximidade a } \\
\text { áreas } \\
\text { recreativas (5) }\end{array}$} & 4 -Sítio localizado a menos de 5 km de uma área recreativa ou atração turística. \\
\hline & 3-Sítio localizado a menos de 10 km de uma área recreativa ou atração turística. \\
\hline & 2 - Sítio localizado a menos de 15 km de uma área recreativa ou atração turística. \\
\hline & 1 - Sítio localizado a menos de 20 km de uma área recreativa ou atração turística. \\
\hline
\end{tabular}

Tabela 5. Critérios e parâmetros de quantificação do Risco de Degradação (Brilha, 2016).

\begin{tabular}{|c|c|}
\hline \multicolumn{2}{|r|}{ Risco de Degradação } \\
\hline Critérios (peso) & Pontos/Parâmetros \\
\hline \multirow{4}{*}{$\begin{array}{l}\text { A - Deterioração } \\
\text { de elementos } \\
\text { geológicos (35) }\end{array}$} & 4-Possibilidade de deterioração de todos os elementos geológicos. \\
\hline & 3 - Possiblidade de deterioração dos principais elementos geológicos. \\
\hline & 2 - Possibilidade de deterioração dos elementos geológicos secundários. \\
\hline & 1-Mínima possibilidade de deterioração dos elementos geológicos secundários. \\
\hline \multirow{4}{*}{$\begin{array}{l}\text { B - Proximidade a } \\
\text { áreas/atividades } \\
\text { com potencial para } \\
\text { causar degradação } \\
\text { (20) }\end{array}$} & 4-Sítio localizado a menos de 50 m de um área/atividade com potencial de degradação. \\
\hline & 3 - Sítio localizado a menos de 200 m de um área/atividade com potencial de degradação. \\
\hline & 2 - Sítio localizado a menos de 500 m de um área/atividade com potencial de degradação. \\
\hline & 1 - Sítio localizado a menos de 1 km de um área/atividade com potencial de degradação. \\
\hline \multirow{4}{*}{$\begin{array}{l}\text { C-Proteção legal } \\
\text { (20) }\end{array}$} & 4 - Sítio localizado em uma área sem proteção legal e sem controle de acesso. \\
\hline & 3-Sítio localizado em uma área sem proteção legal mas com controle de acesso. \\
\hline & 2 -Sítio localizado em uma área com proteção legal mas sem controle de acesso. \\
\hline & 1-Sítio localizado em uma área com proteção legal e controle de acesso. \\
\hline \multirow[t]{4}{*}{$\begin{array}{l}\text { D - Acessibilidade } \\
\text { (15) }\end{array}$} & $\begin{array}{l}\text { 4-Sítio localizado a menos de } 100 \mathrm{~m} \text { de uma estrada pavimentada e com estacionamento } \\
\text { para ônibus. }\end{array}$ \\
\hline & 3 -Sítio localizado a menos de $500 \mathrm{~m}$ de uma estrada pavimentada. \\
\hline & 2 - Sítio acessível por ônibus através de estrada de terra. \\
\hline & $\begin{array}{l}1 \text { - Sítio sem acesso direto por estrada mas localizado a menos de } 1 \text { km de uma estrada } \\
\text { acessível por ônibus. }\end{array}$ \\
\hline \multirow{4}{*}{$\begin{array}{l}\text { E-Densidade } \\
\text { populacional (10) }\end{array}$} & 4-Sítio localizado em um município com mais de 1000 habitantes $/ \mathrm{km}^{2}$. \\
\hline & 3-Sítio localizado em um município com 250-1000 habitantes/km². \\
\hline & 2 - Sítio localizado em um município com 100-250 habitantes/km². \\
\hline & 1 - Sítio localizado em um município com menos de 100 habitantes $/ \mathrm{km}^{2}$. \\
\hline
\end{tabular}




\section{RESULTADOS}

A descrição e a quantificação dos geossítios inventariados está a seguir:

\section{GEOSSÍTIO PRAIA BRAVA}

Coordenadas (UTM): $\quad$ 0462388/7386789

Acesso: $\quad$ Trilha da Praia Brava, pela praia Martin de Sá

Tipologia Dimensional: Área

Elementos Geológicos: Metamórfico, Mineralógico e Tectono-Estrutural

Unidade (CPRM, 2005): Granito foliados Calcialcalinos, tipo I, Pico do Papagaio

Litotipo Predominante: Granito gnaisse

Outros Elementos: Científico, Cultural e Turístico

Relevância Científica: Raridade; Representatividade

O geossítio Praia Brava está localizado no costão sul da praia. A rocha que predomina no local é um granito gnaisse, de coloração branco-rosada (Figura 2.A), pobre em minerais máficos, orientados, de granulação variando entre fina a média (Garda, 1995).

Na porção inicial do costão a rocha granítica, mais recente, faz contato com o gnaisse anfibolítico mais antigo. O bandamento no gnaisse anfibolítico é paralelo à foliação geral (Figura 2.B).

Um dique máfico de cerca de 1,30 m de largura e $20 \mathrm{~m}$ de comprimento cortando o gnaisse se destaca no costão (Figura 2.C) com direção variando de N115 a N160 ${ }^{\circ}$ Tal dique foi descrito em Garda (1995) como um enclave microquartzodiorítico encaixado no granito gnáissico, que segundo a autora é um paleodique.

\section{GEOSSÍTIO MEGABOUDIN DA LAGOA AZUL}

Coordenadas (UTM):

Acesso:

Tipologia Dimensional:

Elementos Geológicos:

Unidade (CPRM, 2005):

Litotipo Predominante:

Outros Elementos:

Relevância Científica:
0463553/7387531

Bairro do Capricórnio, Rodovia Rio-Santos

Área

Metamórfico, Geomorfológico eTecto-Estrutural

Granito foliados Calcialcalinos, tipo I, Pico do Papagaio

Granito gnaisse

Científico e Turístico

Raridade 
O geossítio Megaboudin da Lagoa Azul está localizado na área do costão que limita a Praia do Capricórnio ao sul. Ao lado está a foz do Rio Jetuba, separada do mar por um banco de areia (Figura 3.A) de granulação mais grossa, que se apresenta dinâmico de acordo com a vazão do rio.

Segundo Cruz (1974), o morro ao qual pertence o geossítio é constituído por uma antiga ilha, hoje conectada ao continente. O costão é constituído predominantemente por granito gnaisse, podendo variar a granulação de fina a média, com algumas porções migmatizadas. Ainda, pode-se observar no costão intrusões máficas de extensões variadas, além de diques máficos cortando o gnaisse. Em algumas porções do costão tem-se o contato entre o granito mais recente e o gnaisse máfico, mais antigo (Figura 3.B).

No geossítio destaca-se um boudin de composição anfibolítica com cerca de $3 \mathrm{~m}$ de largura e $15 \mathrm{~m}$ de comprimento, interrompido por fratura do gnaisse encaixante que possui foliação com orientação N340 (Figura 3.C).
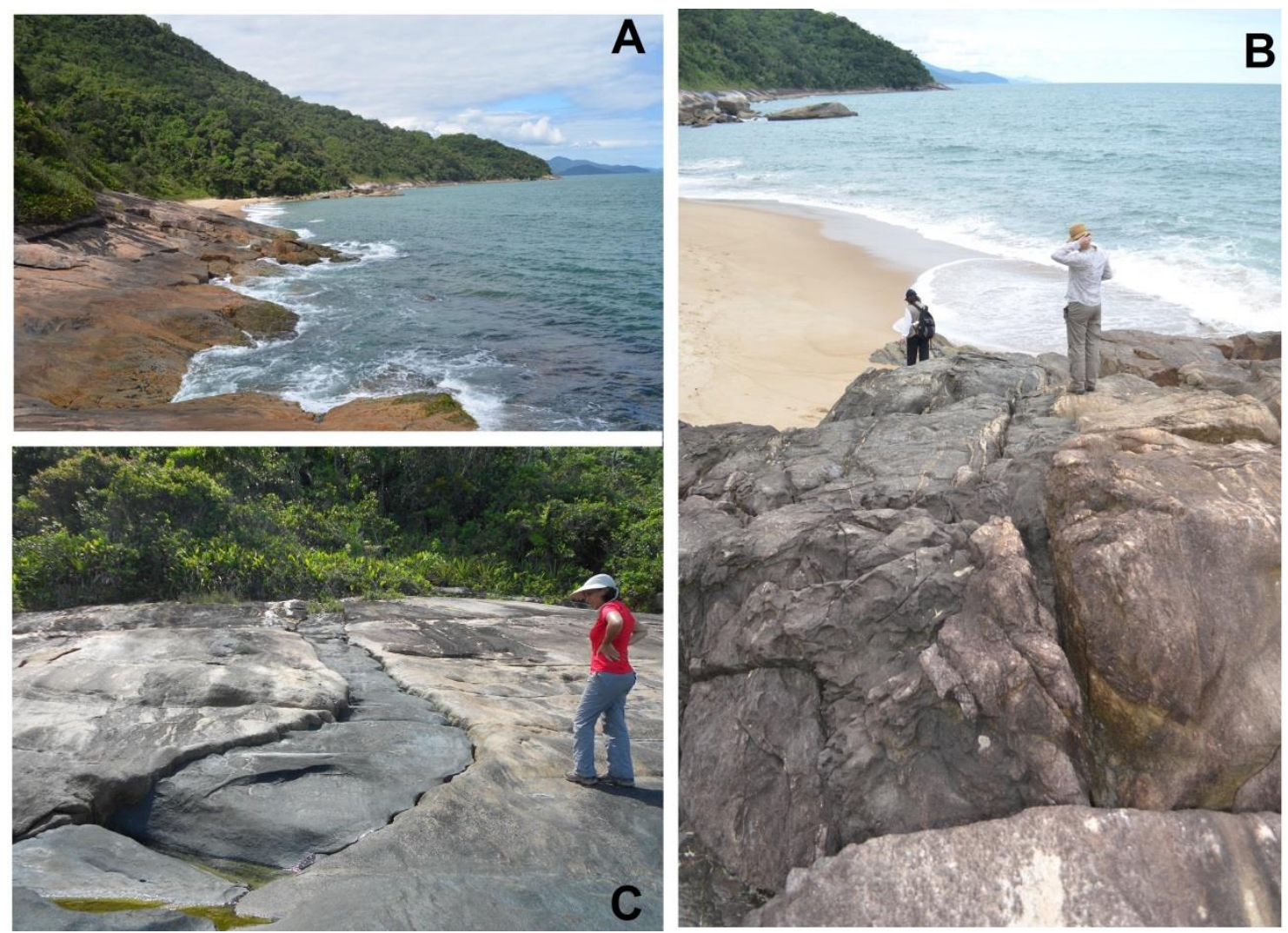

Figura 2. Geossítio Praia Brava: A - costão constituído por granito-gnaisse de coloração rosada; $\mathrm{B}$ - contato entre o granito intrusivo e o gnaisse anfibolítico; C - dique máfico de cerca de $20 \mathrm{~m}$ de comprimento, apresentando mudança na direção de $\mathrm{N} 115^{\circ}$ a $\mathrm{N} 160^{\circ}$. 

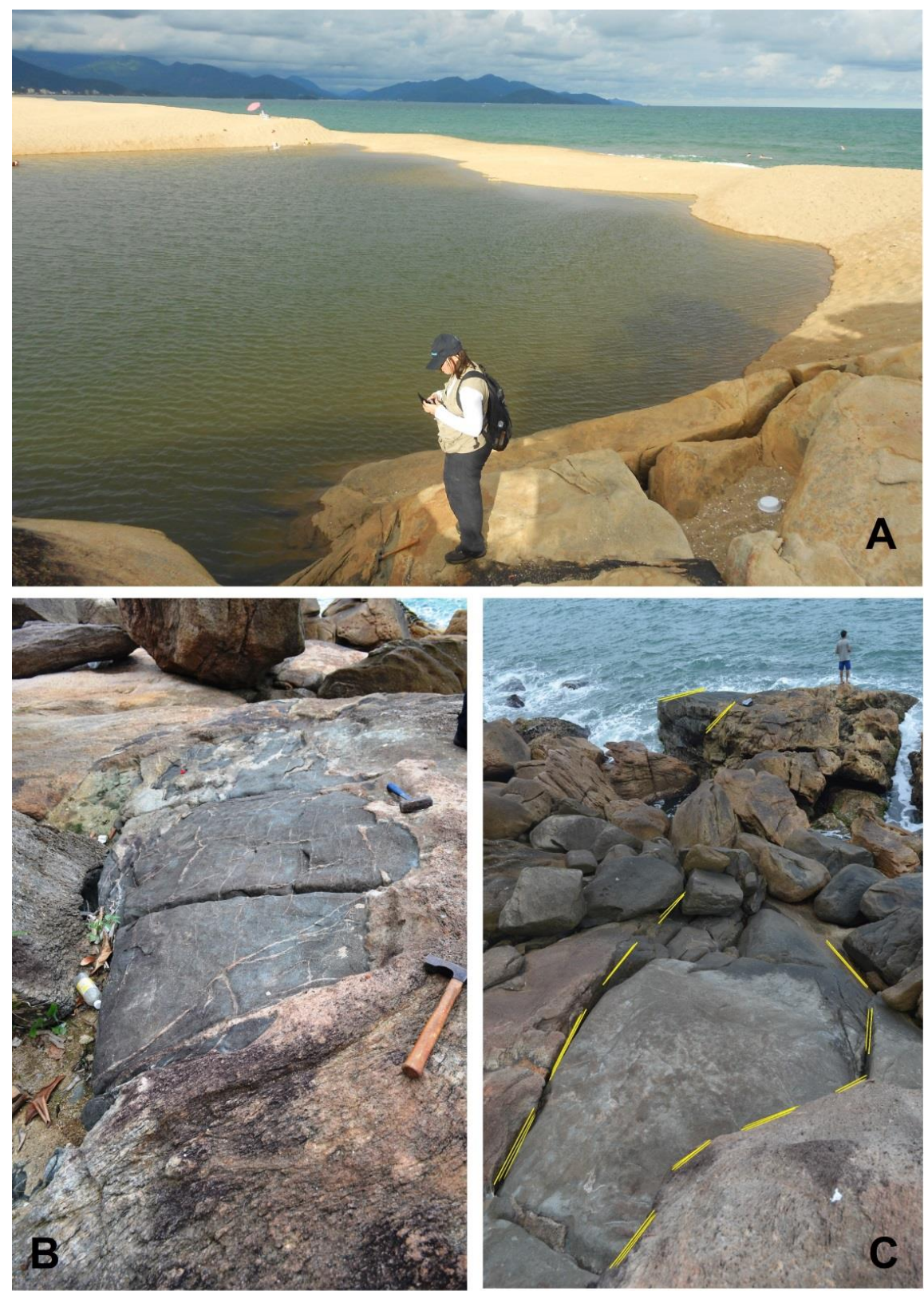

Figura 3. Geossítio Megaboudin da Lagoa Azul: A - costão rochoso e a barra de areia ao fundo, que separa o Rio Jetuba do mar formando uma lagoa; B - contato da rocha granítica mais recente e o gnaisse máfico, mais antigo; C - boudin anfibolítico de cerca de $15 \mathrm{~m}$ de comprimento inserido na rocha gnáissica encaixante.

\section{GEOSSÍTIO MILONITOS DA TABATINGA-ILHA DO TAMANDUÁ}

Coordenadas (UTM):

Acesso:

Tipologia Dimensional:

Elementos Geológicos:

Unidade (CPRM, 2005):

Litotipo predominante:

Outros Elementos:

Relevância Científica:
470168/7392865

Condomínio Costa Verde Tabatinga, ou pela praia

Área

Metamórfico, Mineralógico e Tectono-Estrutural

Granito foliados Calcialcalinos, tipo I, Pico do Papagaio

Gnaisse

Científico

Representatividade 
Este geossítio está localizado dentro da área de um condomínio com acesso privado, no costão que limita a praia de Tabatinga a oeste constituído por rochas granito gnáissicas. Trata-se de um dos mais representativos registros das zonas de cisalhamento associadas à colisão continental que culminou na formação do Gondwana Ocidental.

No geossítio estão dispostas rochas gnáissicas miloníticas (Figura 4.A), com indicadores cinemáticos de movimento destral. A foliação milonítica possui direção N73E mergulhando $65^{\circ}$ para NW e pode estar associada à Zona de Cisalhamento Camburu, que ocorre na região seguindo a direção NE-SW. Localmente ocorrem intrusões de granito fino, leucocrático, apresentando fraturas de resfriamento (Figura 4.B).

O costão está a uma distância de $540 \mathrm{~m}$ da Ilha do Tamanduá, que já esteve conectada ao continente como uma continuação da Serra da Lagoa, em Ubatuba (Cruz, 1974). A ilha é composta por rochas granito gnáissicas rosadas deformadas intrudidas por granito leucocrático fino. Nota-se a presença de um padrão de intemperismo onde os planos de foliação milonítica, similares aos do costão de Tabatinga, são destacadas pela erosão (Figura 4.C). A presença de fraturas indicativas de movimento destral no gnaisse pode estar associada à reativação da zona de cisalhamento (Figura 4.D).

\section{GEOSSÍTIO MILONITOS E CATACLASITOS DA ESTRADA DA PETROBRAS}

Coordenadas (UTM):

Acesso:

Tipologia Dimensional: Elementos Geológicos:

Unidade (CPRM, 2005):

Litotipo Predominante:

Outros Elementos:

Relevância Científica:
434686/7381175

Estrada da Petrobras

Pontual

Metamórfico, Mineralógico e Tectono-Estrutural

Granito foliados Calcialcalinos, tipo I, Pico do Papagaio

Gnaisse

Científico, Didático e Turístico

Integridade

O geossítio está localizado em um trecho da Estrada da Petrobras que liga os municípios de Salesópolis e Caraguatatuba, acompanhando o curso do Rio Juqueriquerê. O geossítio é constituído predominantemente por rochas gnáissicas.

Os gnaisses encontrados no geossítio apresentam foliação milonítica (Figura 5.A) subvertical mergulhando $60^{\circ}$ para NW associadas à Zona de Cisalhamento Camburu, 
uma falha transcorrente destral relacionada à evolução tardia da Faixa Ribeira e com direção NE-SW.
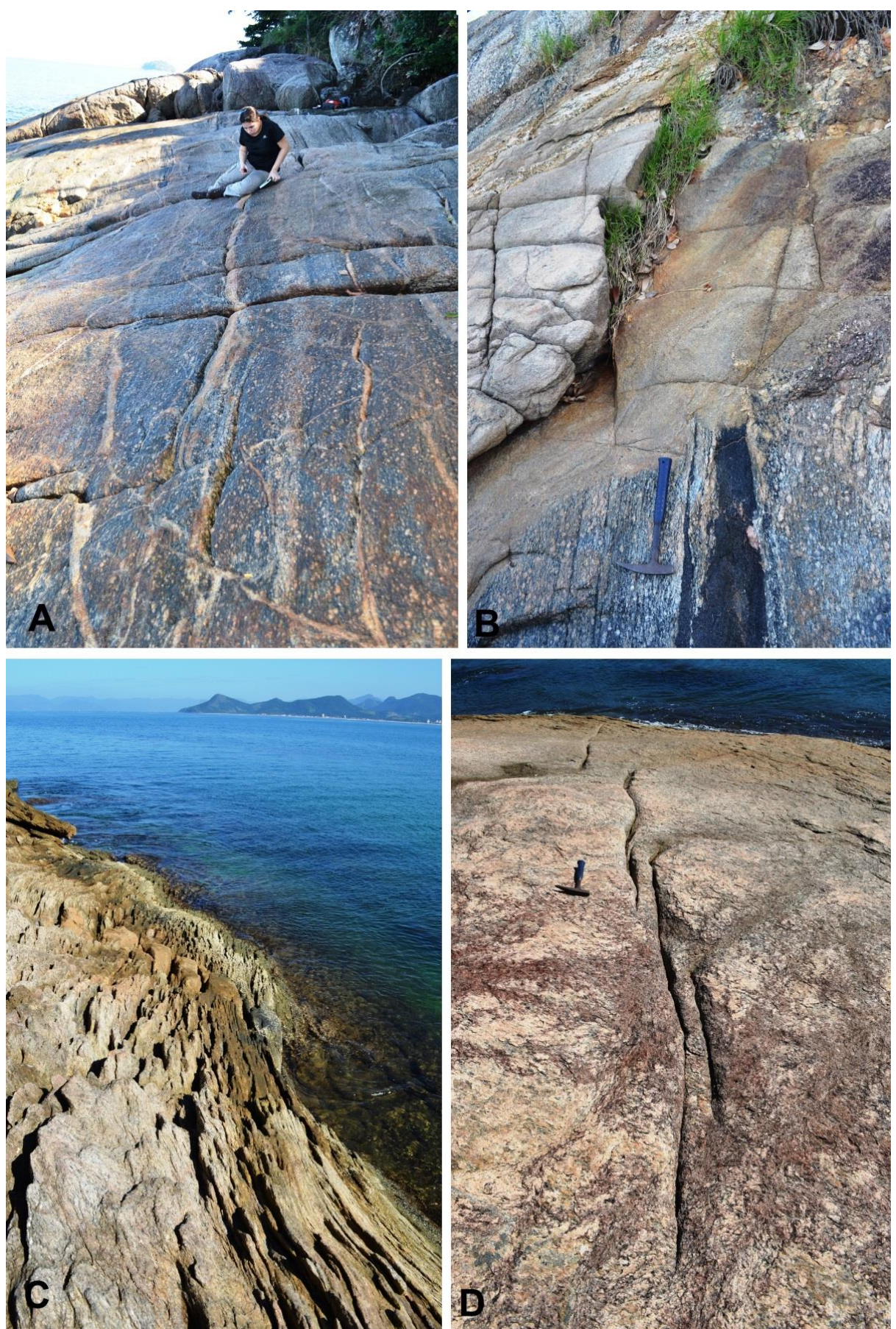

Figura 4. Geossítio Milonitos da Tabatinga-Ilha do Tamanduá: A - foliação milonítica do gnaisse, provavelmente associada à Zona de Cisalhamento Camburu; B - foliação milonítica paralelizando dois litotipos, cortado por um granito mais fino contendo fraturas de resfriamento; C - intemperismo nos planos de foliação milonítica, Ilha do Tamanduá; D - fraturas indicativas de movimento destral, associadas à reativação da zona de cisalhamento, Ilha do Tamanduá.

Campanha et al. (1994) descrevem a presença de cataclasitos na área correspondente ao geossítio, que teriam sido originados devido a uma reativação posterior da zona de 
cisalhamento. Mora et al. (2013), descrevem essas rochas como de textura tipicamente cataclástica com grãos e/ou fragmentos angulosos a subarredondados dispostos de forma aleatória em uma matriz mais fina, os níveis cataclásticos ocorrem em bandas paralelas à foliação milonítica local (Figura 5.B).

A reativação da Zona de Cisalhamento Camburu em nível crustal mais raso também está relacionada à presença de fendas escalonadas, que indicam o movimento destral da zona de cisalhamento (Figura 5.C).
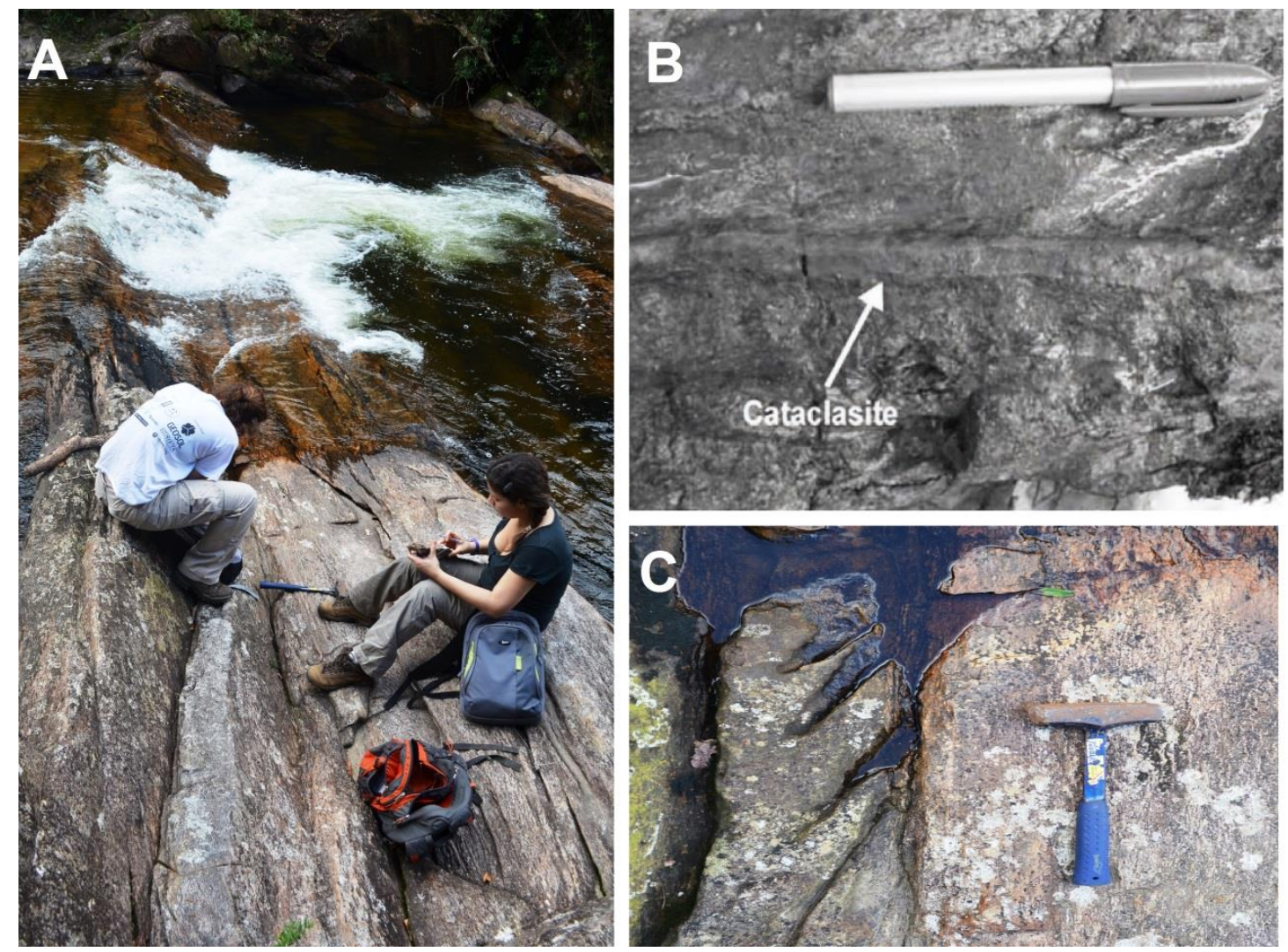

Figura 5. Geossítio Milonitos e Cataclasitos da Estrada da Petrobras: A - gnaisse com foliação milonítica subvertical associado à Zona de Cisalhamento Camburu; B - biotita gnaisse milonítico com cataclasito paralelo à foliação milonítica (Mora et al., 2013); C - fendas escalonadas indicando o movimento destral da zona de cisalhamento.

\title{
GEOSSÍTIO MORRO DO SANTO ANTÔNIO
}

\author{
Coordenadas (UTM): $\quad$ 459064/7388926 \\ Acesso: \\ Tipologia Dimensional: \\ Estrada da Serraria, bairro Sumaré \\ Elementos Geológicos: \\ Mirante \\ e Tectono-Estrutural \\ Unidade (CPRM, 2005): \\ Litotipo Predominante: \\ Outros Elementos: \\ Metamórfico, Paleoambiental, Sedimentar, Geomorfológico \\ Depósitos Quaternários \\ Depósitos Quaternários \\ Científico, Cultural, Didático e Turístico \\ Relevância Científica: \\ Representatividade
}


O geossítio Morro do Santo Antônio está localizado no morro homônimo a $320 \mathrm{~m}$ acima de nível do mar proporcionando a vista de elementos geológicos na paisagem, tais como a Planície de Caraguatatuba, a Serra do Mar, morros residuais e escorregamentos (Figura 6). Além de mirante, o local é utilizado para fins religiosos e para prática de voo livre. O morro está estruturado sobre rocha granítica calcialcalina (Perrotta et al., 2005).

Do geossítio observa-se uma parte do município de São Sebastião e da Ilha de São Sebastião, que está separada do continente pelo canal de São Sebastião e teve sua formação relacionada à tectônica e às variações do nível do mar no Quaternário Superior.

A Planície de Caraguatatuba é a mais extensa do litoral norte e teve sua gênese marcada por fases transgressivas e regressivas do nível do mar no período Quaternário (Suguio \& Martin, 1978) e pelo recuo das escarpas da Serra do Mar. Nessa planície destacam-se três morros residuais que separam as praias do Camaroeiro e Martim de Sá que, Segundo Cruz (1974), constituem antigas ilhas. Em um desses morros - Morro do Camburi - é possível observar um escorregamento de massa.

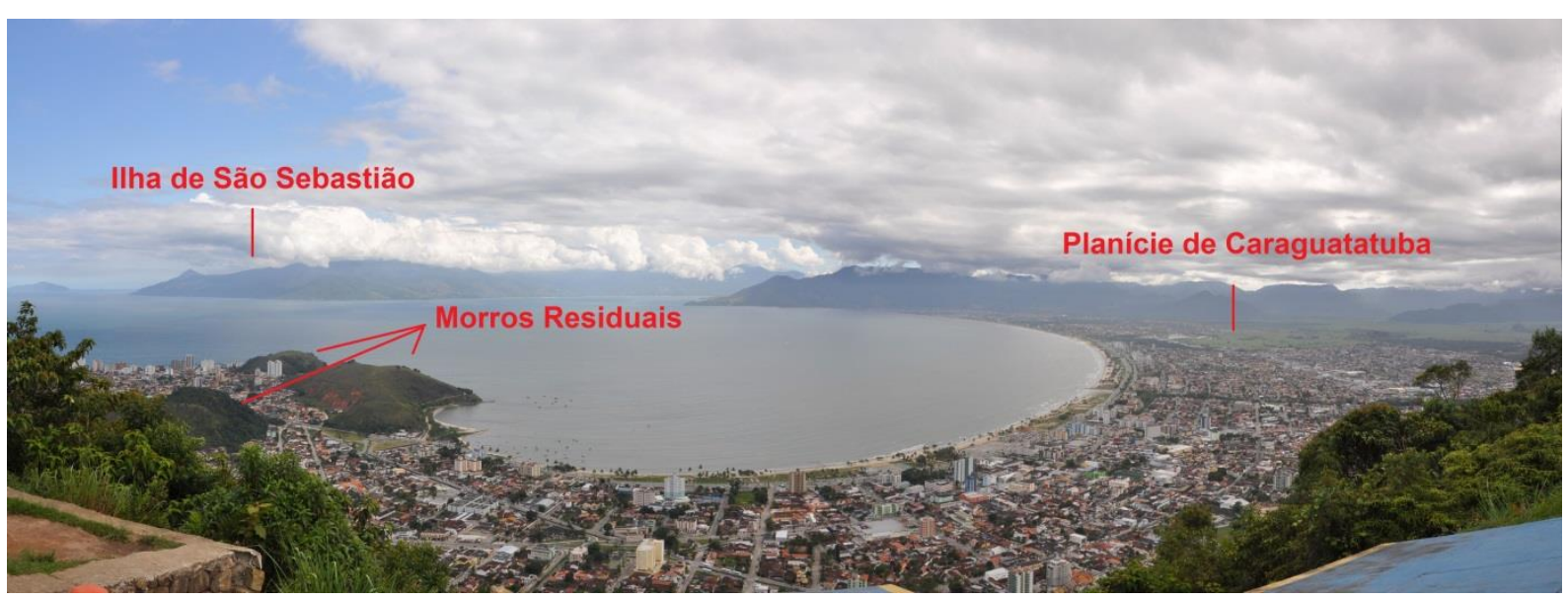

Figura 6. Visão do mirante do Geossítio Morro do Santo Antônio, com destaque para os elementos geológicos da paisagem: Planície de Caraguatatuba, Ilha de São Sebastião e morros residuais, ao fundo na direita está a Serra do Mar. 


\section{GEOSSÍTIO GEOFORMAS DE CARAGUATATUBA}

Coordenadas (UTM): $\quad$ 7386700/ $4596327386255 / 4602137387090 / 461705$

Acesso: $\quad$ Pedra da Freira: Trilha para a Praia do Garcez; Pedra do

Jacaré: Trilha pela Prainha; Pedra do Sapo: Iate Clube ou maré baixa

Tipologia Dimensional: Área Complexa

Elementos Geológicos: $\quad$ Metamórfico e Geomorfológico

Unidade (CPRM, 2005): $\quad$ Granito foliados Calcialcalinos, tipo I, Pico do Papagaio

Litotipo Predominante: Granito gnaisse

Outros Elementos: Cultural, Didático e Turístico

Relevância Científica: Raridade

O Geossítio Geoformas de Caraguatatuba abrange três sítios de interesse geológico relacionados a geoformas com aspectos humanos e animais: Pedra da Freira, Pedra do Jacaré e Pedra do Sapo. Estas geoformas foram ocasionadas pela erosão diferencial da rocha, constituídas por rocha granitóide com associações de augen gnaisses com biotita granitos gnáissicos de granulação média a fina (Chieregati, 1982).

A Pedra da Freira é um bloco rochoso de cerca de $3 \mathrm{~m}$ de altura localizada na Praia do Garcez (Figura 7.A), na base de um dos morros residuais da Serra do Mar na Planície Costeira de Caraguatatuba.

A rocha granito gnáissica de coloração rosada da Pedra da Freira possui intrusões de rocha gnáissica de granulação mais fina e deformada. A geoforma é controlada por um dos planos de fratura da rocha, que cortam a foliação do gnaisse.

A Pedra do Jacaré está localizada no costão do Morro de Martim de Sá (Figura 7.B). O acesso se dá através da uma trilha de aproximadamente $270 \mathrm{~m}$ de extensão com início na Prainha. Trata-se de uma rocha gnáissica deformada com uma porção suspensa que apresenta aparência similar ao dorso de um jacaré, proporcionada pela erosão dos planos de foliação do gnaisse, concordante com a superfície plana da rocha.

A Pedra do Sapo está localizada no costão que limita a Praia Martim de Sá, ao norte. Trata-se de um bloco rochoso in situ de cerca de $7 \mathrm{~m}$ de altura e $16 \mathrm{~m}$ de comprimento (Figura 7.C). No costão são observadas intrusões máficas constituídas por rochas anfibolíticas. Os blocos intemperizados com fissuras poligonais conferem a superfície da rocha o formato de "broa". 

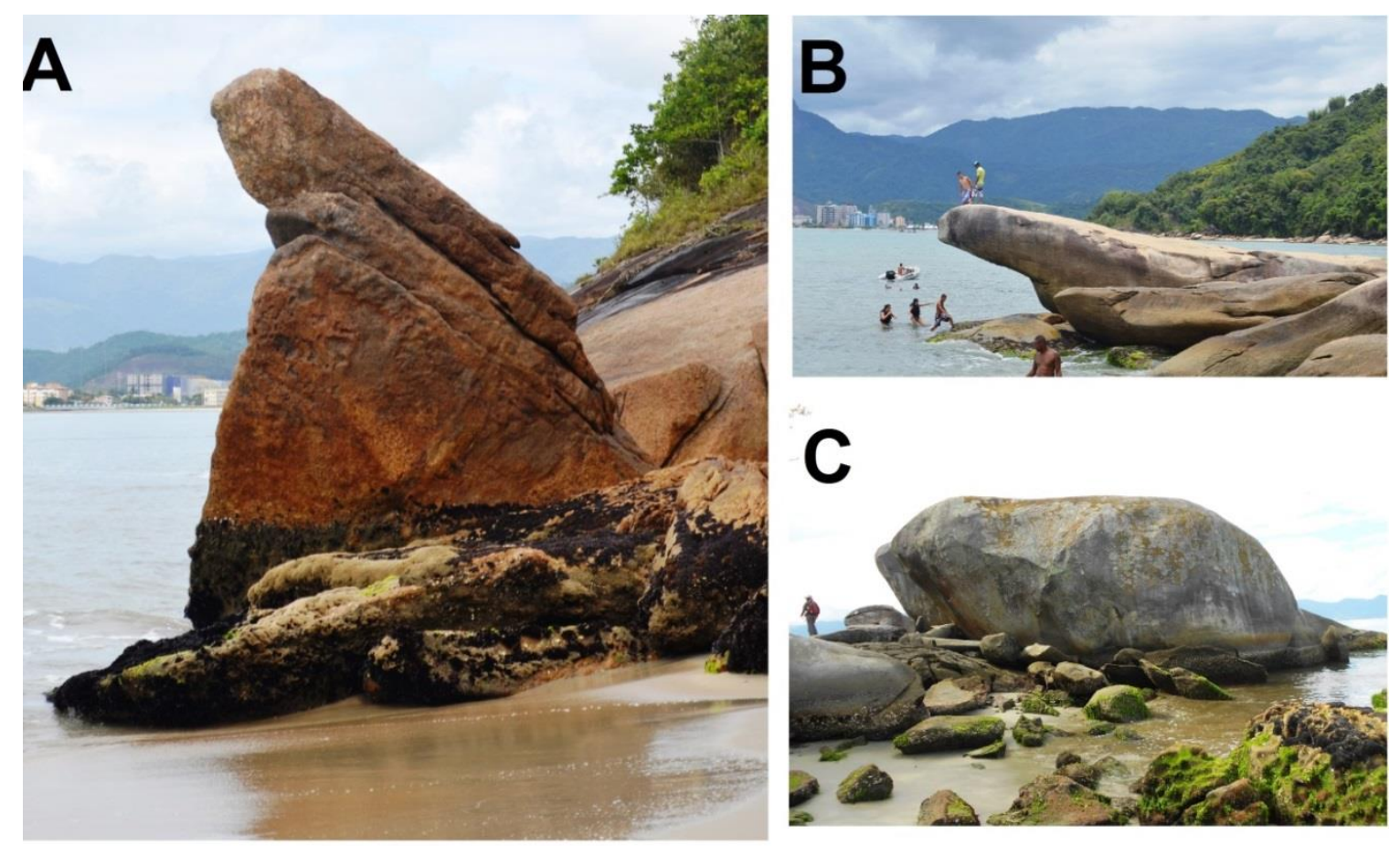

Figura 7. Geossítio Geoformas de Caraguatatuba: A - Pedra da Freira, bloco de rocha granito gnáissica apresentando padrões de fraturamento que dão origem a geoforma; B - Pedra do Jacaré, afloramento de rocha granito gnáissica com porção suspensa; C - Pedra do Sapo, bloco de rocha gnáissica.

\section{GEOSSÍTIO REGISTROS DA CATÁSTROFE}

Coordenadas (UTM):

456190/7390673

Acesso:

PESM - Núcleo Caraguatatuba, Rodovia dos

Tamoios, abaixo da ponte de acesso à Trilha Jequitibá

Tipologia Dimensional:

Pontual

Elementos Geológicos:

Estratigráfico, Geomorfológico e Sedimentar

Unidade (CPRM, 2005):

Papagaio

Litotipo Predominante:

Granito foliados Calcialcalinos, tipo I, Pico do

Outros Elementos:

Granito gnaisse

Relevância Científica:

Cultural, Didático e Social

Representatividade

O geossítio consiste em um depósito de blocos e matacões que registram o movimento de massa em grande escala ocorrido na região no ano de 1967 , conhecido como a "Catástrofe". Segundo o IPT (1988), esse movimento de massa variou de comportamento, passando de escorregamentos a "debris flows" (corrida de detritos/blocos), "mud flows" (corrida de lama) e "mud flood" (enchente com alta concentração de material sólido). Segundo Fúlfaro et al (1976), nos últimos 3.300 anos, tal evento foi a única grande fase de escorregamentos na região. 
O depósito tem cerca de $4 \mathrm{~m}$ de altura (Figura 8.A) e está exposto na margem direita do Ribeirão do Ouro. Possui blocos e matacões de gnaisse de até 1 metro de diâmetro sobrepostos em meio a matriz argilosa. No leito do rio estão dispostos diversos blocos e matacões de até $2 \mathrm{~m}$ de diâmetro (Figura 8.B). Esta granulação sugere que o depósito está próximo do local de proveniência dos blocos ou, alternativamente, foi resultado de correntes aquosas com muita energia. À medida que o rio desce, a granulação diminui, passando a apresentar seixos de gnaisse de até $20 \mathrm{~cm}$ de diâmetro (Figura 8.C).
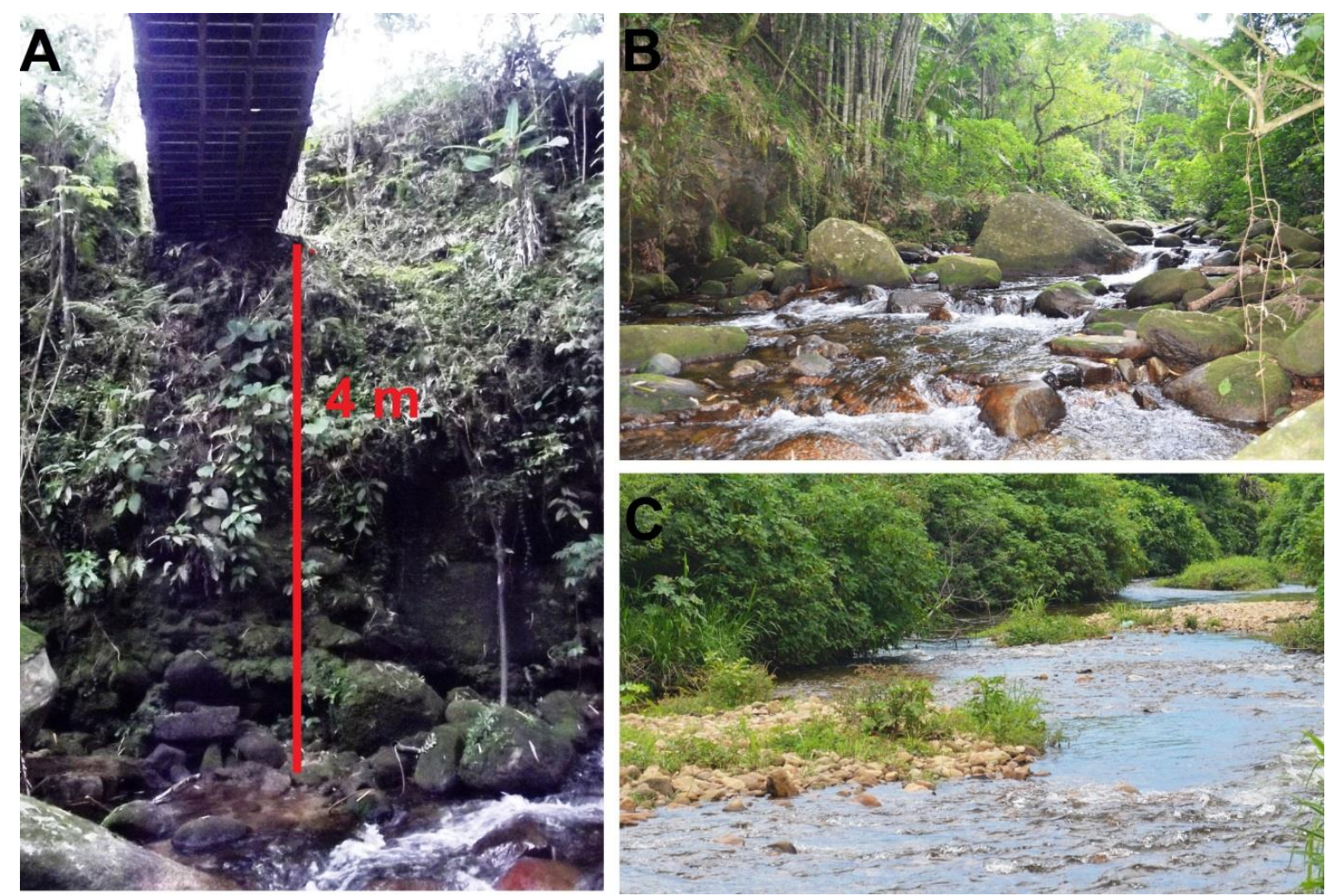

Figura 8. Geossítio Registros da Catástrofe: A - perfil marginal do Rio do Ouro com depósito de rochas e matacões sobrepostos; B - rochas e matacões dispostos no leito do Rio do Ouro; C trecho mais a jusante do Rio do Ouro com blocos de menor granuloção dispostos no leito.

\section{QUANTIFICAÇÃO}

Os valores obtidos por meio da quantificação para os geossítios de Caraguatatuba estão mostrados na Tabela 6 e na Figura 9. O geossítio Morro do Santo Antônio obteve o mais alto Valor Científico (VC), seguido dos geossítios Megaboudin da Lagoa Azul, Milonitos e Cataclasitos da Estrada da Petrobras e Praia Brava, todos com alta representatividade, porém apenas os geossítios Morro do Santo Antônio e Milonitos e Cataclasitos da Estrada da Petrobras obtiveram alto valor de conhecimento científico por obter publicações internacionais. Já o geossítio Megaboudin da Lagoa Azul 
alcançou o segundo lugar no ranking pelo alto valor no item "G - Limitações de Uso", relacionado à possibilidade de uso e coleta de amostras no geossítio.

Tabela 6. Valores obtivos através da avaliação quantitativa pelo método de Brilha (2016). Geossítios: PB - Praia Brava; LA - Megaboudin da Lagoa Azul; TT - Milonitos da TabatingaIlha do Tamanduá; MEP - Milonitos e Cataclasitos da Estrada da Petrobras; MAS - Morro do Santo Antônio; GC - Geoformas de Caraguatatuba; RC - Registro da Catástrofe.

\begin{tabular}{|c|c|c|c|c|c|c|c|}
\hline \multicolumn{8}{|c|}{ Geossítios } \\
\hline Quantificação & PB & LA & TT & MEP & MSA & GC & RC \\
\hline$A$ & 4 & 4 & 4 & 4 & 4 & 4 & 4 \\
\hline $\mathrm{C}$ & 0 & 0 & 0 & 4 & 4 & 0 & 0 \\
\hline $\mathrm{D}$ & 4 & 4 & 4 & 2 & 4 & 4 & 2 \\
\hline$E$ & 2 & 2 & 2 & 2 & 4 & 1 & 2 \\
\hline $\mathrm{G}$ & 2 & 4 & 1 & 2 & 2 & 2 & 2 \\
\hline Total & 270 & 290 & 230 & 280 & 300 & 265 & 210 \\
\hline \multicolumn{8}{|c|}{ Uso Potencial } \\
\hline$A$ & 4 & 3 & 2 & 4 & 3 & 4 & 4 \\
\hline $\mathrm{B}$ & 1 & 3 & 3 & 0 & 4 & 3 & 4 \\
\hline $\mathrm{C}$ & 3 & 4 & 1 & 2 & 3 & 4 & 3 \\
\hline $\mathrm{G}$ & 4 & 4 & 4 & 1 & 4 & 4 & 4 \\
\hline $\mathrm{H}$ & 0 & 1 & 0 & 0 & 1 & 2 & 0 \\
\hline $\mathrm{I}$ & 2 & 3 & 2 & 2 & 2 & 3 & 1 \\
\hline$J$ & 4 & 4 & 4 & 4 & 4 & 4 & 3 \\
\hline \multicolumn{8}{|c|}{ Educacional } \\
\hline $\mathrm{Ke}$ & 1 & 1 & 1 & 1 & 4 & 3 & 4 \\
\hline Le & 3 & 3 & 3 & 3 & 4 & 2 & 3 \\
\hline $\begin{array}{c}\text { Total Uso } \\
\text { Educacional }\end{array}$ & 256 & 261 & 226 & 201 & 294 & 288 & 274 \\
\hline \multicolumn{8}{|c|}{ Turístico } \\
\hline $\mathrm{Kt}$ & 2 & 2 & 2 & 2 & 4 & 4 & 3 \\
\hline $\mathrm{D}$ & 1 & 1 & 3 & 0 & 4 & 3 & 4 \\
\hline$E$ & 2 & 2 & 2 & 2 & 2 & 2 & 2 \\
\hline Total & 110 & 170 & 240 & 95 & 290 & 180 & 155 \\
\hline
\end{tabular}

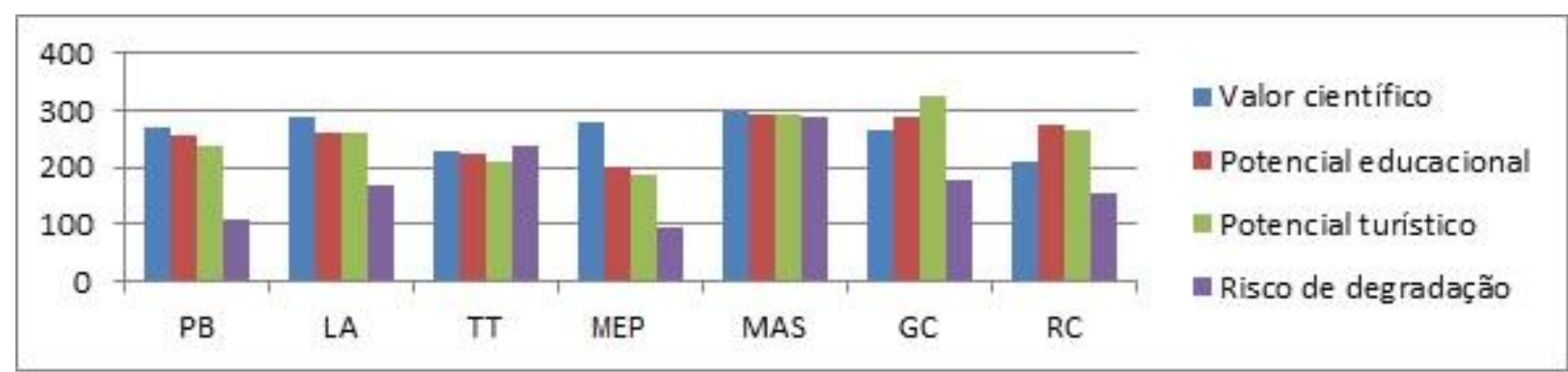

Figura 9. Gráfico dos valores obtidos através da quantificação. Geossítios: PB - Praia Brava; LA - Megaboudin da Lagoa Azul; TT - Milonitos da Tabatinga-Ilha do Tamanduá; MEP Milonitos e Cataclasitos da Estrada da Petrobras; MAS - Morro do Santo Antônio; GC Geoformas de Caraguatatuba; RC - Registro da Catástrofe. 
Os geossítios Milonitos da Tabatinga-Ilha do Tamanduá e Registros da Catástrofe obtiveram os valores de Valor Científico mais baixos, isso devido à baixa pontuação alcançada no item "F - Raridade", por estes apresentarem características geológicas existentes em outros sítios dentro do município.

O Potencial para uso educacional (Pe) levou em consideração dois itens principais: Potencial didático e diversidade geológica, nesse caso o geossítio que obteve maior valor de Pe foi o geossítio Morro do Santo Antônio, por apresentar pontecial didático para todos os níveis escolares e alta diversidade geológica, seguido pelos geossítios Geoformas de Caraguatatuba, Registros da Catástrofe, Megaboudin da Lagoa Azul e Praia Brava. Os geossítios Milonitos da Tabatinga-Ilha do Tamanduá e Milonitos e Cataclasitos da Estrada da Petrobras obtiveram valores baixos, justificados pela necessidade de um maior nível de conhecimento geológico para a interpretação do geossítio.

Os geossítios que obtiveram valores mais altos para o Potencial para uso turístico (Pt) foram, em ordem descrescente: Geoformas de Caraguatatuba, Morro do Santo Antônio, Registros da Catástrofe e Megaboudin da Lagoa Azul.

Os valores do Risco de degradação (Rd) variaram de Moderado à Baixo (Tabela 7), sendo os geossítios Morro de Santo Antônio e Milonitos da Tabatinga-Ilha do Tamanduá os que obtiverem valores mais altos. Esse resultado foi alcançado principalmente pelos itens: B - Proximidade à áreas/atividades com potencial para degradação; e D - Acessibilidade, no qual esses dois geossítios receberam altas pontuações.

Tabela 7. Classificação do risco de degradação de acordo com os valores obtidos na quantificação (Brilha, 2016).

\begin{tabular}{|c|c|}
\hline Valor total & Risco de degradação \\
\hline$<200$ & Baixo \\
\hline $201-300$ & Moderado \\
\hline $301-400$ & Alto \\
\hline
\end{tabular}




\section{DISCUSSÃO DOS RESULTADOS}

O estudo do patrimônio geológico de um determinado local leva em consideração não apenas aspectos técnicos e científicos, mas também abrange um estudo multidisciplinar com levantamento dos aspectos culturais, políticos, econômicos e sociais da região.

A partir do levantamento do patrimônio geológico de Caraguatatuba é possível planejar meios de conservar e inseri-lo no contexto social, para que seja utilizado pela sociedade de forma racional, garantindo a capacidade de carga de cada geossítio e considerando suas potencialidades de uso.

\section{INVENTÁRIO}

O inventário do patrimônio geológico de Caraguatatuba definiu sete geossítios que se destacam geologicamente pela sua relevância científica, e que auxiliam no estudo e na reconstituição da história geológica e evolutiva da Terra, assim como dos processos erosivos e deposicionais que transformam a paisagem.

Seis desses geossítios estão diretamente relacionados a amalgamação e fragmentação do Supercontinente Gondwana Ocidental, apresentando sua história evolutiva a partir de registros estruturais, petrológicos e mineralógicos bem preservados nas rochas. Tais geossítios representam uma parte da geologia que influencia diretamente os elementos da paisagem na região do litoral norte de São Paulo.

O geossítio Registros da Catástrofe está inserido em um contexto geológico mais recente, abordando um evento de grande representatividade geotécnica e cultural no município, os movimentos de massa que ocorreram no ano de 1967. Trata-se do melhor registro desse evento conservado na paisagem do município.

\section{QUANTIFICAÇÃO}

Embora o inventário do patrimônio geológico seja baseado na relevância científica do geossítio, a quantificação do patrimônio geológico utiliza elementos antrópicos na valoração dos geossítios, como acessibilidade, limitações de uso, segurança, logística, densidade populacional e nível econômico da população. 
O método quantitavo utilizado neste trabalho (Brilha, 2016) mostrou-se eficiente, embora tenha apresentado problemas de adaptação para a área de estudo. Por estar inserida em um país com extensa área territorial, a comparação dos elementos geológicos do geossítio com o resto do país pode não ser tão representativa, como no item: "Uniquissidade" do potencial de uso.

\section{VALOR CIENTÍFICO}

O alto valor científico de um geossítio está relacionado com a representatividade de uma determinada característica geológica, conhecimento científico internacional e feições bem preservadas (Brilha, 2016). O geossítio Morro do Santo Antônio apresentou maior valor científico, o que pode ser explicado por se tratar de um mirante, possuindo uma extensa área além do geossítio que engloba diversos elementos da geodiversidade, aos quais alguns deles já foram estudados e publicados em artigos internacionais (Suguio \& Martin, 1978; Souza, 1989; Souza \& Suguio, 2003).

\section{POTENCIAL PARA USO EDUCACIONAL}

Os geossítios que apresentaram alto potencial para uso educacional foram Morro do Santo Antônio, Geoformas de Caraguatatuba, Registros da Catástrofe, Megaboudin da Lagoa Azul e Praia Brava. Eles devem ser trabalhados de forma a apresentar os dados geológicos de forma coerente de acordo com o público. Para este tipo de uso, sugere-se a elaboração de folhetos e placas informativas, que podem auxiliar na divulgação dos elementos geológicos didáticos no geossítio.

O geossítio Morro do Santo Antônio apresenta alto potencial didático, onde um dos elementos geológicos vizualizados a partir do mirante é o escorregamento de massa, fenômeno bastante frequente na região e que faz parte da história do município. Esse geossítio pode ser utilizado para conscientizar a população acerca dinâmica natural das escarpas da Serra do Mar.

\section{POTENCIAL PARA USO TURÍSTICO}

Os geossítios que obtiveram maiores valores de Potencial para uso turístico foram aqueles com a geomorfologia como um dos elementos geológicos de interesse, tais geossítios tendem a obter valores mais altos pela sua relevência estética e pela facilidade de compreensão pelo público em geral (Brillha, 2016). 
Os geossítios Geoformas de Caraguatatuba, Morro do Santo Antônio, Registros da Catástrofe e Megaboudin da Lagoa Azul já possuem um fluxo de visitantes, porém com outros fins (culturais, esportivos, ecológicos e recreativos). Neste caso, informações geológicas sobre esses geossítios devem ser agregadas ao turismo já existente, através da divulgação científica em uma linguagem acessível.

\section{RISCO DE DEGRADAÇÃO}

O risco de degradação do geossítio Morro do Santo Antônio está relacionada principalmente ao crescimento urbano na Planície de Caraguatatuba, que representa um dos elementos geológicos da paisagem visualizados pelo mirante do geossítio. A Planície de Caraguatatuba já sofreu ao longo dos anos com modificações causadas por ações antrópicas, como o aplainamento de morros residuais para construções imobiliárias.

O geossítio Milonitos da Tabatinga-Ilha do Tamanduá está localizado em uma área particular de um condomínio fechado, com acesso restrito. Trata-se de um geossítio localizado muito próximo à urbanização e pode estar vulnerável a ações antrópicas.

\section{GESTÃO DOS GEOSSÍTIOS}

Até o presente momento, o município de Caraguatatuba não possui legislação específica para garantir a conservação do patrimônio geológico, com exceção do geossítio Registros de Catástrofe que está indiretamente protegido por estar inserido em uma área de trilha ecológica do PESM, os demais geossítios estão ameaçados pela ausência de proteção legislativa.

Neste caso, o presente trabalho representa uma ferramenta de auxílio para a gestão desses locais a partir da informação e divulgação da importância geológica existente por meio de relatórios para o poder público. Além disso, a inserção do patrimônio geológico na consciência coletiva e em planos de desenvolvimento econômico e cultural do município pode ser feita por meio de políticas educacionais e turísticas e com a utilização dos geossítios de forma sustentável.

\section{CONCLUSÕES}

O município de Caraguatatuba concentra uma parte relevante da história geológica do Supercontinente Gondwana Ocidental, e está localizado em uma região atrativa para 
o turismo, com os elementos da paisagem - praias e serras - utilizados para atrair turistas em todos os períodos do ano.

O alto fluxo de visitantes no município sobretudo em um período concentrado, aliado à falta de divulgação do patrimônio geológico existente no local, implica em risco de degradação desses geossítios, sendo a falta de informação é a maior ameaça. Alguns geossítios merecem maior atenção por estar mais vulnerável, como o geossítio Morro do Santo Antônio, com os elementos da geodiversidade visualizados pelo mirante ameaçados, principalmente a Planície de Caraguatatuba e os morros residuais.

A existência de uma área de proteção ambiental no município - PESM, pode ser utilizada como um meio de incorporação do patrimônio geológico ao patrimônio natural, fazendo com que esses geossítios recebam a proteção legal do parque.

O presente trabalho faz parte de uma pesquisa para uma proposta geoturística na região. Os geossítios que apresentaram maior potencial para o geoturismo são aqueles que, além de altos valores no Potencial de uso turístico, apresentam baixo Risco de degradação. Assim, tem-se o geossítio Geoformas de Caraguatatuba como o de maior potencial para o uso geoturístico, seguido pelo geossítio Morro do Santo Antônio.

O inventário e a quantificação do patrimônio geológico devem ser utilizados como argumento para justificar uma estratégia de geoconservação e gestão dos geossítios no município, além da instalação de estruturas para melhorar as condições de visita. Futuras etapas devem incluir o monitoramento, valorização e divulgação dos elementos geológicos apresentados nos geossítios.

\section{AGRADECIMENTOS}

À Fundação de Amparo à Pesquisa do Estado de São Paulo - FAPESP (Processo 2011/17261-6), à Pró-Reitoria de Pesquisa da Universidade de São Paulo, por meio do Programa de Incentivo à Pesquisa que permitiu a criação do Núcleo de Apoio à Pesquisa em Patrimônio Geológico e Geoturismo (GeoHereditas) e ao Conselho Nacional de Desenvolvimento Científico e Tecnológico - CNPQ, pela bolsa de doutorado concedida. 


\section{REFERÊNCIAS}

1. ALEXANDROWICZ, Z.; KOZLOWSKI S. 1999. From selected geosites to geodiversity conservation - Polish example of modern framework. In: Barettino D, Vallejo M, Gallego E. Towards the balanced management and conservation of the geological heritage in the new millenium. Sociedad Geológica de España, Madrid, Spain, p. 40-44.

2. ALMEIDA, F.F.M.; HASUI, Y.; BRITO NEVES, B.B.\& FUCK, R.A. 1977. Províncias estruturais brasileiras. In: Simpósio de Geologia do Nordeste, 8, Campina Grande, Boletim Especial, p.12-13. Anais da Academia Brasileira de Ciências, 83(3): 891-906.

3. BRILHA, J.B.R. 2005. Patrimônio Geológico e Geoconservação: a conservação da natureza na sua vertente geológica. Palimage Editora, 190 p.

4. BRILHA, J. 2016. Inventory and Quantitative Assessment of Geosites and Geodiversity Sites: a Review. Geoheritage.

5. BRUSCHI, V. M. 2007. Desarrollo de uma metodologia para la caracterización, evaluación y gestión de los recursos de la geodiversidad. Tesis Doctoral, Facultad de Ciencias - Universidad de Cantabria, Santander, 263p.

6. CAMPANHA, G.A.C. ENS, H.H. 1993. Estrutura geológica na Região de São Sebastião. In: Simpósio de Geologia do Sudeste, 3. Boletim de Resumos. Rio de Janeiro, SBG. p. 51-52.

7. CAMPANHA, G.A.C. ENS, H.H. PONÇANO, W.L. 1994. Analise morfotectônica do Planalto do Juqueriquere, São Sebastião. Revista Brasileira de Geociências, v.24, n.1, p.32-42.

8. CHIEREGATI, L. A. 1982. Mapa Geológico da Folha de Caraguatatuba. Serviço Geológico do Brasil - CPRM, Folha SF-23-Y-D-VI-1. Escala 1:500.000.

9. CRUZ, O. 1974. A Serra do Mar e o litoral na área de Caraguatatuba: contribuição à geomorfologia litorânea tropical. São Paulo, Instituto de Geografia, USP. 181p. (Teses e monografias, 11).

10. FUERTES-GUTIÉRREZ, I.; FERNÁNDEZ-MARTINÉZ, E. 2010. Geosites inventory in the Leon Province (Northwestern Spain): a tool to introduce geoheritage into regional environmental management. Geoheritage 2(1-2):5775

11. FÚlfaro, V.J., PONÇANO, W.L., BISTRICHI, C.A., STEIN, D.P. 1976. Escorregamentos de Caraguatatuba: Expressão atual e registro na coluna sedimentar da Planície Costeira adjacente. In: Congresso Brasileiro de Geologia de Engenharia, Anais. Rio de Janeiro - RJ, p. 341-350.

12. GARCIA, M.G.M., 2012. Gondwana Geodiversity and Geological Heritage: Examples from the north coast of São Paulo State, Brazil. Anuário do Instituto de Geociências (Online). , v.35, p.101 - 111.

13. GARCIA, M.G.M., MARTINS, L., DEL LAMA, E.A., BOUROTTE, C.L.M. 2014. O Inventário do Patrimônio Geológico da Região Costeira do Estado de São Paulo: Base Metodológica, Adaptações e Considerações. Anais do $47^{\circ}$ Congresso Brasileiro de Geologia. Salvador - BA.

14. GARCÍA-CORTÉS, A.; CARCAVILLA URQUÍ, L. 2009. Documento metodológico para la elaboración del inventario español de lugares de interés geológico (IELIG), version 12. Instituto Geológico y Minero de, España, Madrid 
15. GARDA, G.M. 1995. Os Diques Básicos e Ultrabásicos entre as cidades de São Sebastião e Ubatuba, Estado de São Paulo. 156f e anexos. Tese de Doutorado, Instituto de Geociências, Universidade de São Paulo, 1995.

16. GRAY, J. M. 2013. Geodiversity: valuing and conserving abiotic nature, $2^{\text {nd }}$ edn. John Wiley \& Sons, Chichester.

17. IBGE - Instituto Brasileiro de Geografia e Estatística. 2007. Residências Secundárias no Total de Domicílios por Município. Disponível em: <http://cidades.ibge.gov.br>. Acesso em: 02 mai. 2015.

18. IBGE - Instituto Brasileiro de Geografia e Estatística. 2014. Cidades: Caraguatatuba. Disponível em: 〈http://cidades.ibge.gov.br >. Acesso em: 02 mai. 2015.

19. INSTITUTO DE PESQUISAS TECNOLÓGICAS (IPT). 1988. Estudo das instabilizações de encostas da Serra do Mar na região de Cubatão objetivando a caracterização do fenômeno "corrida de lama" e prevenção de seus efeitos. São Paulo: IPT, 1988. 185 p. (Relatório n. 26258).

20. INSTITUTO PÓLIS. 2012. Resumo Executivo de Caraguatatuba. Litoral Sustentável: Desenvolvimento com Inclusão Social. Petrobras, São Paulo, 35p.

21. LIMA, F.F.; BRILHA, J.; SALAMUNI, E. 2010. Inventorying geological heritage in large territories: a methodological proposal applied to Brazil. Geoheritage 2(3-4):91-99

22. PERROTA, M.M. SALVADOR, E.D. LOPES, R.C. D'AGOSTINHO, L.Z. 2005. Mapa Geológico do Estado de São Paulo. 1:750.000. Programa levantamentos geológicos básicos do Brasil. Serviço Geológico do Brasil. São Paulo.

23. MELO, M.S. \& PIRES NETO, A.G. 1977. Esboço geológico da província costeira entre as Serras do Juqueriquerê e Parati, Estado de São Paulo. In: SIMP. BRAS. GEOL., 1. São Paulo. Atas... São Paulo, SBG. p. 303-323.

24. MORA, C. A. S., CAMPANHA, G. A. C., WEMMER, K. 2013. Microstructures and K-Ar illite fine-fraction ages of the cataclastic rocks associated to the Camburu Shear Zone, Ribeira Belt, Southeastern Brazil. Brazilian Journal of Geology, 43(4): 607-622, December 2013.

25. PADGURSCHI, V. 2000. A Dilatação do Espaço Urbano. Santo Antônio de Caraguatatuba: memórias e tradições de um povo. Org.: Campos, J. F. Caraguatatuba: FUNDACC, 2000. 468p.

26. PROCHOROFF, R. 2014. Patrimônio geológico de Ilhabela-SP.: estratégias de geoconservação. Dissertação (Mestrado). Institudo de Geociências/ USP . São Paulo, 2014. $176 \mathrm{p}$.

27. REVERTE, F. C. 2014. Avaliação da Geodiversidade em São Sebastião - SP, com Patrimônio Geológico. Dissertação (Mestrado), Institudo de Geociências/ USP, São Paulo. 208p.

28. SANTOS, P. L. A. 2014. Patrimônio geológico em Áreas de Proteção Ambiental: Ubatuba - SP. Dissertação (Mestrado): Institudo de Geociências/ USP, São Paulo, 207 p.

29. SECRETARIA DE MEIO AMBIENTE (SMA)/INSTITUTO FLORESTAL (IF). 1977. Decreto $\mathrm{n}^{\mathrm{o}} 10.251$ de 31 de agosto de 1977. Disponível em: <http://www.al.sp.gov.br/norma/?id=152524> Acesso em: 02 mai. 2015.

30. SOUZA, C. R. de G. 1989. Evidence for an holocene lagoonal environment on the Caraguatatuba coastal plain, State of São Paulo, Brazil.. In: International Symposium of Global Change in South America during the Quaternary, São Paulo., 1989, São Paulo, (SP). Special Publication., v. 1. p. 312-316. 
31. SOUZA C.R. de G. 1990. Considerações sobre os Processos Sedimentares Quaternários e Atuais na Região de Caraguatatuba, Litoral Norte do Estado de São Paulo. Instituto Oceanográfico, Universidade de São Paulo, São Paulo, Dissertação de Mestrado, 314p.

32. SOUZA, C.R. de G.; SUGUIO, K. 2003. The coastal erosion risk zoning and the State of São Paulo Plan for Coastal Management. Journal of Coastal Research, v. 35, p. 530-547.

33. SUGUIO, K. \& MARTIN, L. 1978. Formações quaternárias marinhas do litoral paulista e sul fluminense. In: International Symposium on Coastal Evolution in The Quaternary. São Paulo, IGCB/IG-USP; SBG, 1978. 55p. (Special Publication, 1).

34. WIMBLEDON, W. A. 2011. Geosites - a mechanism for protection, integrating national and international valuation of heritage sites. Geologia dell'Ambiente, supplemento n. 2/2011:13-25 
ANEXO B - MÉTODO DE SELEÇÃO E PROPOSTAS DE USO DOS SÍTIOS DA GEODIVERSIDADE: EXEMPLO DO LITORAL NORTE DO ESTADO DE SÃO PAULO, BRASIL

\begin{abstract}
ARRUDA, K.E.C; GARCIA, M.G.M; DEL LAMA, E.A.; MUCIVUNA, V.C; REVERTE, F.C. 2017. Método de Seleção e Propostas de Uso dos Sítios da Geodiversidade: Exemplo do Litoral Norte do Estado de São Paulo, Brasil. Anuário do Instituto de Geociências .UFRJ, Rio de Janeiro. 40 (3): 32 56.
\end{abstract}

\title{
MÉTODO DE SELEÇÃO E PROPOSTAS DE USO DOS SÍTIOS DA GEODIVERSIDADE: EXEMPLO DO LITORAL NORTE DO ESTADO DE SÃO PAULO, BRASIL
}

Karlla Emmanuelle Cunha Arruda, Maria da Glória Motta Garcia, Eliane Aparecida Del Lama, Vanessa Costa Mucivuna \& Fernanda Coyado Reverte

Universidade de São Paulo, Núcleo de Apoio à Pesquisa em Patrimônio Geológico e Geoturismo, Instituto de Geociências. Rua do Lago, 562, Butantã, 05508-080 - São Paulo - SP, Brasil. E-mail: karllaarruda@usp.br; mgmgarcia@usp.br; edellama@usp.br; vanessa.mucivuna@usp.br; fernanda.reverte@usp.br

\section{Resumo}

A geodiversidade há tempos sofre as consequências antrópicas da falta de informação acerca da sua importância, sendo colocada em segundo plano nas políticas de conservação da natureza e valorizada apenas pela extração de seus recursos. No início do século XIX, a criação de alguns parques nacionais no mundo, tendo como atração principal a geodiversidade, mostrou que essa situação pode mudar se investirmos no potencial de uso de alguns locais da geodiversidade. Deste modo, surgem os "sítios da geodiversidade", locais que apresentam potencial para uso educativo e turístico com oferta de informação geológica. Este trabalho objetiva apresentar o método utilizado para a seleção dos sítios da geodiversidade do litoral norte do estado de São Paulo e discutir os resultados de sua quantificação para tecer propostas de uso para estes locais. A seleção dos sítios baseou-se em três etapas: i) pré-seleção: pesquisas e levantamentos bibliográficos; ii) seleção parcial: eliminação dos sítios sem potencial educativo ou turístico; e iii) seleção final: com base nos trabalhos de campo. O resultado do inventário abrange a descrição e avaliação quantitativa de 25 sítios da geodiversidade, que foram quantificados por meio da plataforma GEOSSIT do Serviço Geológico do Brasil. Com base nos valores numéricos do uso potencial educativo, turístico e do risco de degradação, foram propostas medidas estruturais e atividades recreativas para estes sítios. Este trabalho permitiu avaliar a potencialidade de uso da geodiversidade como subsídio ao turismo e educação em geociências, para gerar desenvolvimento para as comunidades e um ambiente sustentável como um todo.

Palavras-chave: Estratégias de geoconservação; divulgação científica; geodiversidade; quantificação 


\begin{abstract}
Geodiversity has for a long time suffered anthopic consequences due to the lack of information about its importance. On several occasions, geodiversity is marginalized in nature conservation policies and its worth is attributed solely to the resources that it can provide. At the beginning of the nineteenth century, some national parks which had geodiversity as their main attraction were created in the world, showing that the scenario can be changed if we invest in the potential use of some geodiversity sites. In this context, geodiversity sites - places where geologic information is provided and where geodiversity shows potential for educational or tourist purposes - emerge. This paper aims to show the method used for selecting geodiversity sites on the north coast of the São Paulo State and to discuss the results of their quantification in order to propose uses for these sites. The selection of the sites followed three steps: i) preselection: research and bibliographical review; ii) partial selection: removal of the sites without educational or tourist potentials; and iii) final selection: based on fieldwork. The inventory result includes the description and quantitative assessment of twenty-five geodiversity sites which were quantified through GEOSSIT, a plataform of the Geological Service of Brazil. Based on numerical values of educational and tourist potential use and risk of degradation, structural measures and recreation activities for these sites are proposed. This paper allowed for the measurement of geodiversity potential as a subsidy for tourism and geosciences education to foster development for communities and maintain a sustainable environment.
\end{abstract}

Keywords: Geoconservation strategies; scientific dissemination; geodiversity; quantification

\title{
1 Introdução
}

O meio abiótico, embora seja a base estrutural do planeta, sempre foi colocado em segundo plano nas políticas públicas voltadas à interpretação ambiental, visto que o foco destas ações sempre priorizou o contexto da biodiversidade. No entanto, a geodiversidade e seus produtos favoreceram o desenvolvimento dos seres vivos, fornecendo materiais essenciais para a sustentação da vida e evolução das espécies, podendo-se inferir, portanto, que a biodiversidade está diretamente condicionada à geodiversidade. Se ambas estão interligadas e possuem o mesmo valor na natureza, por que a geodiversidade e os eventos geológicos que a produz são pouco conhecidos e divulgados?

Isso acontece pela maior facilidade de interpretação apresentada nos elementos da biodiversidade, não só por sua grande variedade de formas e cores, mas por sua divulgação científica ser mais valorizada no meio acadêmico. A geodiversidade é sim atraente para o público geral, como exemplos temos o Grand Canyon, nos Estados Unidos, as Cataratas do Iguaçú, no Brasil, e os vulcões do Havaí, locais com alta taxa de 
visitação por conta do turismo de cunho geológico. Entretanto, mesmo com todo esse poder atrativo, por que a geodiversidade ainda não dispõe de grandes políticas de divulgação científica?

A causa principal deste problema está na ausência de investimentos na área de divulgação geocientífica dentro da academia, onde pesquisas geológicas com teor estritamente técnico recebem mais financiamento e atenção dos geólogos. Nas últimas décadas, isso tem mudado, a começar pela criação do termo "geodiversidade", citado pela primeira vez em 1991 no I Simpósio Internacional para a Proteção do Patrimônio Geológico, em Digne-Les-Bains na França, onde foi elaborada a "Declaração Internacional dos Direitos à Memória da Terra". Contudo, foi na Conferência de Malvern sobre Conservação Geológica e Paisagística, ocorrida em 1993, no Reino Unido, que o termo passou a ser conhecido (Gray, 2004).

Desde então, o conceito de geodiversidade foi redefinido por diversos autores (Dixon, 1996; Nieto, 2001; Stanley, 2001; Kozlowski, 2004; Gray, 2004; Brilha, 2005; Serrano \& Ruiz-Flano, 2007; Burek \& Prosser, 2008; Gray, 2013) até o presente. Neste trabalho foi utilizada a definição de Gray (2013), que define a geodiversidade como "a variedade natural (diversidade) de elementos geológicos (rochas, minerais, fósseis), geomorfológicos (relevo, topografia, processos físicos), hidrológicos e solos, incluindo as associações, estruturas, sistemas e constribuições à paisagem".

Dentro da geodiversidade existem locais que se destacam por apresentarem características geológicas de extrema importância e que merecem ser conservados. Estes locais, ao longo das últimas décadas, receberam diversas denominações, tais como "ponto de interesse geológico", definido por Duque et al. (1978) como "áreas que mostram uma ou várias características de importância dentro da história geológica de uma região natural". O termo "lugar de interesse geológico", definido em Arana et al. (1992), acrescentou que tais lugares também tratam de recursos renováveis de índole cultural que constituem o patrimônio geológico dos habitantes atuais e das gerações futuras. Em contrapartida a este último conceito surge o termo "domínios de interesse geológico" (Lago et al., 2001) abrangendo o lugar de interesse geológico para zonas mais amplas e multidisciplinares.

O termo "geossítio" surgiu da palavra em inglês "geosite" e foi definido em 1991 como "manifestações geológicas ou geomorfológicas, terrenos ou paisagens que possuem uma informação indispensável para o entendimento da história geológica de um país, região ou continente, ou processos de caráter global" (Wimbledon et al., 1999). 
Em Brilha (2005) este termo foi definido como locais que apresentam um ou mais elementos da geodiversidade resultantes de processos naturais ou por meio de intervenção humana, sendo uma área bem delimitada geograficamente com algum valor representativo, no âmbito científico, pedagógico, cultural ou turístico, podendo apresentar um ou mais elementos de interesse, tais como estrutural, paleontológico, mineralógico, geomorfológico e estratigráfico. Segundo o autor, o conjunto de geossítios constitui o patrimônio geológico de uma dada região.

Em Brilha (2016) o termo geossítio foi redefinido, passando a ser exclusivo para locais da geodiversidade que possuam valor científico relevante e estejam in situ. Os locais que apresentem importância científica, mas que se encontrem ex situ são denominados "elementos do patrimônio geológico". Por sua vez, os locais da geodiversidade que não possuam valor científico relevante, mas que sejam importantes no contexto didático, turístico e/ou cultural, são denominados "sítios da geodiversidade", quando in situ e "elementos da geodiversidade", quando ex situ. Esta proposta de classificação da diversidade natural torna possível diferenciar claramente sítios que têm alto interesse científico, mas limitado valor turístico e/ou educativo, daqueles que não possuem alta relevância científica mas que podem ser essenciais na gestão e uso da geodiversidade. Embora a geoesfera seja composta por elementos abióticos, tem uma intensa relação com o meio biótico e as atividades antrópicas. Portanto, os sítios da geodiversidade, mesmo não possuindo um valor científico tão relevante, podem conter um valor turístico, educativo e/ou cultural muito alto, merecendo destaque e políticas voltadas à geoconservação.

A partir do conceito de "sítio da geodiversidade" assume-se a noção de que a geoconservação é uma ciência social e interdisciplinar, fazendo com que o cientista tenha contato com outros fatores antropológicos, como a cultura local e não só o conhecimento geológico para obter dados e classificar corretamente tais locais de relevância para a geodiversidade. A inserção desta nova classificação serve como subsídio para a implantação de políticas de gestão e de utilização correta da geodiversidade, em uma classificação que define os geossítios como locais de extrema importância científica e que merecem destaque na comunidade acadêmica geológica, mas que não necessariamente sejam locais disponíveis para visitação e atraentes para o público geral.

A função "uso" tem importância fundamental na avaliação dos sítios da geodiversidade, para que o público geral possa usufruir daquele local, seja como um 
afloramento com ótima qualidade de observação e potencial didático para estudantes, seja como uma paisagem de beleza cênica e potencial interpretativo para o público leigo, ou ainda um afloramento de rocha aparentemente comum, mas que tenha grande importância cultural e/ou religiosa para a comunidade. Em qualquer um dos casos, o caráter geológico chama a atenção de turistas e estudantes, e fornece informações sobre a geodiversidade local. Para este levantamento, o cientista deve ultrapassar a fronteira do conhecimento geocientífico e buscar informações em outras áreas do conhecimento nas ciências sociais.

Mucivuna (2016) e Santos (2016) realizaram o inventário dos sítios da geodiversidade nas regiões de Bertioga-SP e no Agreste de Pernambuco, respectivamente. No primeiro foram inventariados 4 sítios da geodiversidade, com propostas para desenvolvimento de atividades turísticas e educativas. Em Santos (2016) foram inventariados 9 sítios da geodiversidade e sugeridos roteiros geoturísticos para divulgação destes locais. Em ambos os casos considerou-se como parte do inventário dos sítios da geodiversidade a proposta de uso dos mesmos.

O litoral norte de São Paulo tem sido alvo de diversos estudos acerca do patrimônio geológico desde 2012, apresentando um total de 35 geossítios inventariados em Prochoroff (2014), Reverte (2014), Santos (2014), Arruda et al. (2015) e Reverte \& Garcia (2016), representando a relevância da geodiversidade existente na região diretamente relacionada com a amalgamação e fragmentação do Supercontinente Gondwana ocidental. Neste sentido, o presente estudo tem por objetivo apresentar o método de seleção para o inventário dos sítios da geodiversidade no litoral norte do estado de São Paulo (ao qual não inclui os geossítios já inventariados), a quantificação destes sítios e, a partir dos dados obtidos, tecer propostas para o uso turístico e educativo.

\section{2 Área, materiais e métodos}

\subsection{Localização da área e contexto geológico}

O litoral norte do estado de São Paulo abrange os municípios de Ubatuba, Caraguatatuba, São Sebastião e Ilhabela, ocupando uma área de aproximadamente 2.000 $\mathrm{km}^{2}$ de extensão (Figura 1). 


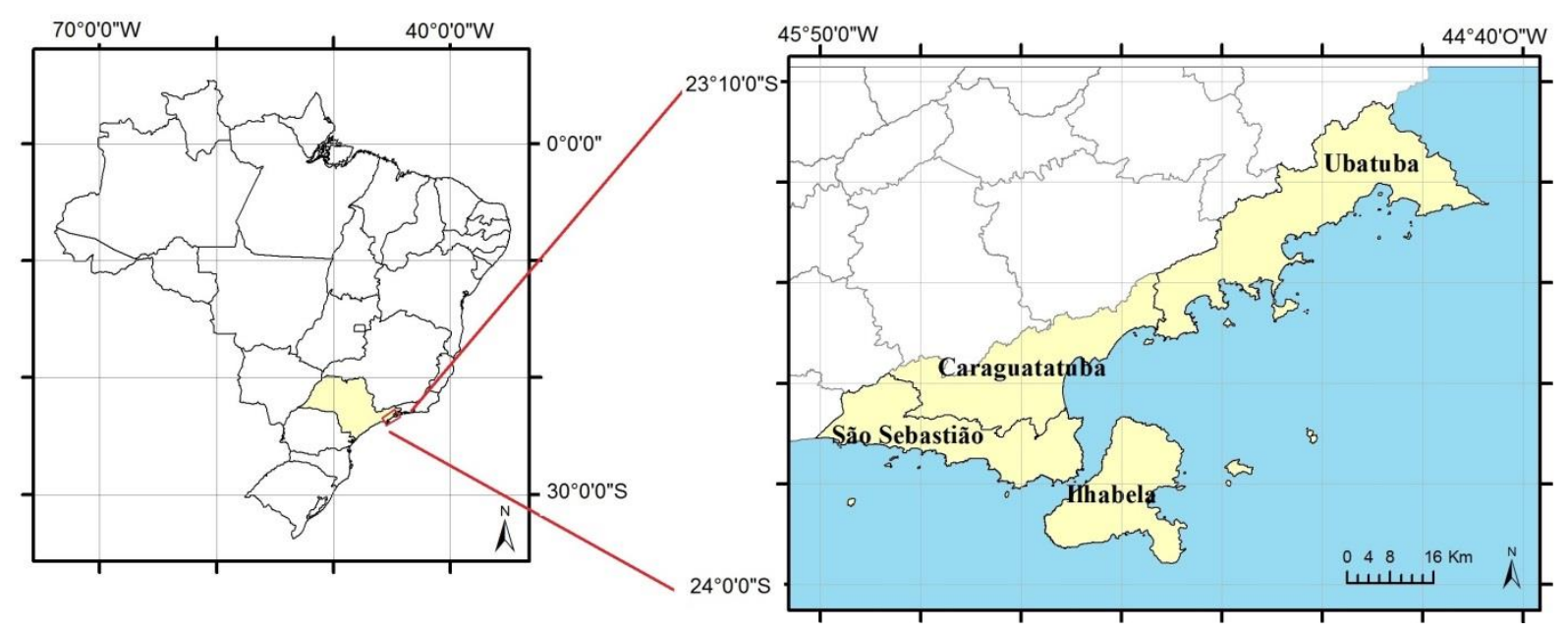

Figura 1 Localização do litoral norte do estado de São Paulo.

A geologia do litoral norte de São Paulo está diretamente associada à evolução do Supercontinente Gondwana, aglutinado durante o Ciclo Brasiliano, no Neoproterozoico-Cambriano, e fragmentado durante o Jurássico-Cretáceo. Desse modo, registros dos diferentes eventos tectônicos ocorridos na região encontram-se nas rochas, descritas por Perrotta et al. (2005), (Figura 2).

A região está inserida na Faixa Ribeira, um dos orógenos que compõem a Província Mantiqueira. O orógeno Ribeira (Heilbron \& Machado, 2003) corresponde a um cinturão de cisalhamento transcorrente que margeia a costa Atlântica Brasileira por cerca de $1.400 \mathrm{~km}$, cuja origem está associada à colisão entre os crátons São Francisco e Congo Ocidental, ocorrida entre 650-510 Ma (Heilbron et al., 2008; Tupinambá et al., 2012), durante o Ciclo Tectônico Brasiliano-Pan-Africano. Subdivide-se em várias unidades geológicas e na área de estudo engloba o Domínio Costeiro (Heilbron et al., 2008).

O processo de rifteamento que formou o Atlântico Sul é responsável pelo enxame de diques da Serra do Mar, caracterizado por dois eventos magmáticos distintos: o magmatismo toleítico do Cretáceo Inferior e o magmatismo alcalino ocorrido do Cretáceo Superior ao Paleógeno (Garda, 1995). Tais diques podem ser visualizados ao longo de todo o litoral.

A área de estudo é caracterizada por zonas de cisalhamento transcorrentes associadas aos riftes do Cinturão Ribeira (Zalán \& Oliveira, 2005). A Zona de Cisalhamento Camburu está associada ao rifte litorâneo e constitui uma faixa de rochas miloníticas, ultramiloníticas, blaslomiloníticas e protomiloníticas, predominantemente quartzo-feldspáticas, além de cataclasitos (Maffra, 2000; Mora et al., 2013). O ramo que 
desvia para leste, acompanhado pelo curso do Rio Camburu e adentrando a Planície Costeira de Caraguatatuba, foi interpretado como sendo a falha principal por Melo \& Pires Neto (1977).

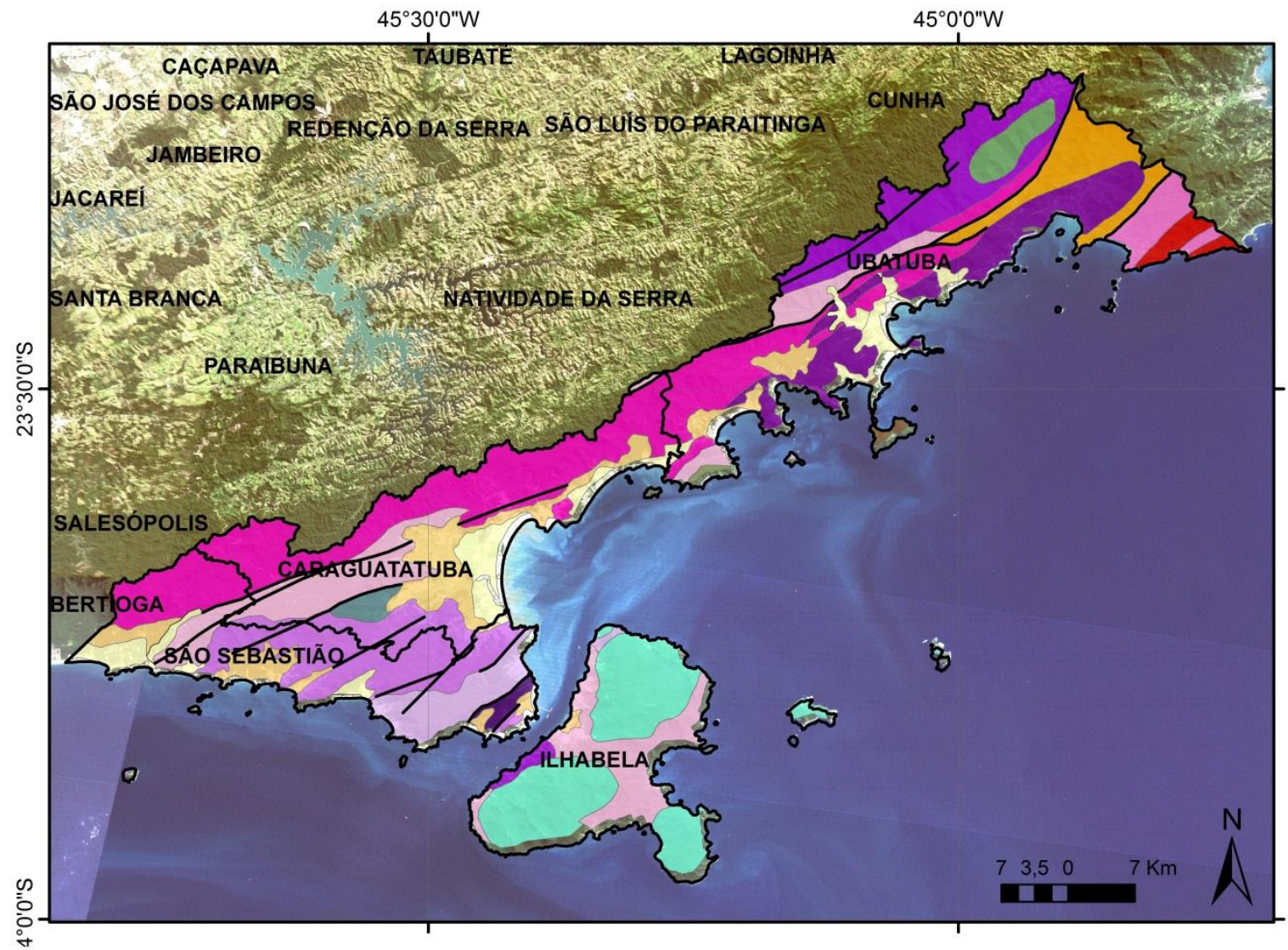

\section{Legenda}

\section{Litologia}

Coberturas detríticas indiferenciadas

Depósitos aluvionares

Depósitos litorâneos

Complexo Pico do Papagaio

Unidade de gnaisses bandados

Unidade de gnaisses peraluminosos

Unidade granito-gnáissica migmatítica

Unidade ortognáissica

Unidade quartzítica

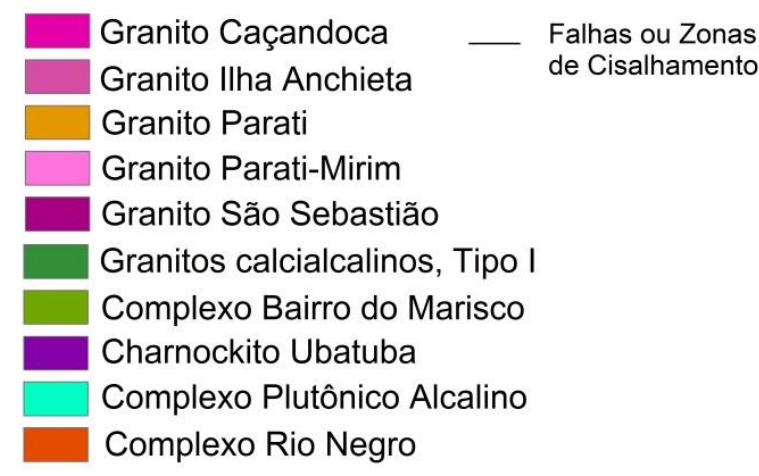

Figura 2 Mapa Geológico da área de estudo. Modificado de Perrotta et al. (2005).

A geomorfologia na região é composta por duas unidades distintas: a Serra do Mar e a Planície Costeira. A Serra do Mar corresponde a um conjunto de escarpas que se estende cerca de $1.000 \mathrm{~km}$ entre a costa do Rio de Janeiro até Santa Catarina 
(Almeida \& Carneiro, 1998). Constituída por rochas ígneas e metamórficas, apresenta altas declividades e altitudes variadas, atingindo $1.670 \mathrm{~m}$ na região de Ubatuba. Sua gênese, posterior ao processo de separação do Supercontinente Gondwana, é atribuída a eventos tectônicos ocorridos no Cenozoico, com movimentações verticais (Almeida, 1976; Asmus \& Ferrari, 1978), responsáveis pela formação de blocos falhados e desnivelados, onde os processos erosivos passaram a atuar de forma intensa a partir do Cretáceo inferior.

A Planície Costeira, por sua vez, representa uma unidade geomorfológica caracterizada por apresentar relevo plano gerado por processos litorâneos desenvolvendo-se, sobretudo, em função da evolução das vertentes das escarpas serranas, das variações do nível do mar e deposição sedimentar. O município de Caraguatatuba possui a maior Planície Costeira da região, formando uma baía com cerca de 10 km de extensão.

\subsection{Aspectos socioeconômicos}

A história econômica da região está diretamente ligada aos fatores geográficos e recursos geológicos, como a instalação dos portos em Ubatuba e posteriormente em São Sebastião, a exploração mineral, especialmente do charnockito (Verde Ubatuba), e o turismo direcionado às zonas de praia a partir da década de 1950. Atualmente, atividades ligadas ao turismo e lazer movimentam a economia da região, cujos índices de visitação se elevam de modo exorbitante durante feriados e temporada de verão Os valores referentes à população na região variam entre 100.000 habitantes fixos e 230.000 flutuantes (Seade, 2011), corroborando a importância do turismo na região (Tabela 1).

Tabela 1 Dados socioeconômicos dos municípios do litoral norte de São Paulo (Seade, 2011).

\begin{tabular}{|c|c|c|c|c|}
\cline { 2 - 5 } \multicolumn{1}{c|}{} & Ubatuba & Caraguatatuba & São Sebastião & Ilhabela \\
\hline Área (km²) & 724 & 485 & 399 & 347 \\
\hline Número de Praias & 102 & 17 & 28 & 47 \\
\hline População fixa & 84.872 & 110.384 & 82.079 & 31.508 \\
\hline População Flutuante & 117.000 & 100.000 & 100.000 & 100.000 \\
\hline PIB per capita (R\$) & $20.024,62$ & $26.896,77$ & $66.186,40$ & $222.540,06$ \\
\hline Analfabetismo (\%) & 5,82 & 4,72 & 5,85 & 5,31 \\
\hline IDH & 0,751 & 0,759 & 0,772 & 0,756 \\
\hline
\end{tabular}


O crescimento populacional somado à ocupação desordenada, iniciados por volta dos anos 1950, ocasionaram graves problemas ambientais na região. Questões relativas ao esgotamento sanitário, descarte irregular de resíduos sólidos e ocupação de encostas, por exemplo, são recorrentes e as medidas voltadas à mitigação destes problemas são conduzidas de forma ineficaz pelo poder público (Teixeira et al., 2011).

Além do atrativo turístico concebido pelas praias, a região abrange o Parque Estadual da Serra do Mar, o Parque Estadual de Ilhabela e o Parque Estadual da Ilha Anchieta, Unidades de Conservação (UCs) criadas para proteger a biodiversidade da Mata Atlântica. Estes parques dispõem de atividades ligadas ao ecoturismo, como visitação a cachoeiras, trilhas de aventura, trilha fluvial no Rio Fazenda - que mostra o ecossistema manguezal, trilha sensorial, trilhas de ciclismo, e passeios com observação de pássaros. Estas atividades oferecidas pelas UC's são de extrema importância na valorização da natureza, levando turistas e escolas ao contato direto com o meio natural.

\subsection{Materiais e métodos}

\subsubsection{Seleção de potencias sítios da geodiversidade}

O método de seleção dos sítios da geodiversidade foi feito com base em três etapas e está sintetizado adiante (Tabelas 2, 3, 4 e 5):

1) Pré-seleção: Conforme descrito em Brilha (2016) esta etapa incluiu todos os pontos encontrados a partir de pesquisas e levantamentos em sites de turismo, materiais divulgativos, livros, trabalhos acadêmicos e entrevistas com pesquisadores, e que apresentaram potencial para serem enquadrados como sítios da geodiversidade. Ao total foram pré-selecionados 55 potenciais sítios da geodiversidade na região;

2) Seleção parcial: Nesta etapa foram eliminados os sítios da pré-seleção que não se enquadravam na definição de sítio da geodiversidade, por não apresentarem acessibilidade, segurança ou potencial educativo ou turístico suficientes. Esta seleção foi realizada com base em informações obtidas por pesquisadores que trabalham na região; e

3) Seleção Final: Os sítios selecionados na etapa anterior foram investigados por meio de trabalhos de campo a fim de conferir sua potencialidade. Os pontos que não apresentaram no campo acessibilidade, segurança ou potencial educativo e/ou turístico 
adequados foram eliminados. A lista final resultou em 25 sítios da geodiversidade distribuídos nos quatro municípios do litoral norte.

Tabela 2 Processo seletivo dos sítios da geodiversidade no município de Ubatuba.

\begin{tabular}{|c|c|c|c|}
\hline $\begin{array}{l}\text { Coordenadas } \\
\text { (UTM) }\end{array}$ & Pré-Seleção & Seleção Parcial & Seleção Final \\
\hline $503549 / 7414985$ & $\begin{array}{c}\text { Charnockito da Cachoeira do } \\
\text { Prumirim }\end{array}$ & $\begin{array}{c}\text { Charnockito da Cachoeira do } \\
\text { Prumirim }\end{array}$ & $\begin{array}{c}\text { Charnockito da Cachoeira } \\
\text { do Prumirim }\end{array}$ \\
\hline $483339 / 7397607$ & Entrada da Trilha das 7 praias & Baixo interesse geocientífico & - \\
\hline $515197 / 7416565$ & Praia da Fazenda & Praia da Fazenda & Praia da Fazenda \\
\hline $492627 / 7401816$ & Praia das Toninhas & Baixo interesse geocientífico & - \\
\hline $494644 / 7404690$ & Praia do Tenório & Baixo interesse geocientífico & - \\
\hline $512611 / 7416317$ & $\begin{array}{l}\text { Praia das Conchas - Trilha da Brava } \\
\text { da Almada }\end{array}$ & Baixo interesse geocientífico & - \\
\hline $485408 / 7401087$ & Praia Domingas Dias & Baixo interesse geocientífico & - \\
\hline $495808 / 7409778$ & Praia de Fora (costão sul) & Baixo interesse geocientífico & - \\
\hline $492263 / 7396234$ & Mirante do Engenho & Mirante do Engenho & Mirante do Engenho \\
\hline $523503 / 7417109$ & Cachoeira da escada & Baixo interesse geocientífico & - \\
\hline $487552 / 7413914$ & Cachoeira do Pé da Serra & Cachoeira do Pé da Serra & Dificuldade de acesso \\
\hline $514716 / 7409685$ & Ilha das Couves & Ilha das Couves & $\begin{array}{l}\text { Baixo interesse } \\
\text { geocientífico }\end{array}$ \\
\hline $505496 / 7414025$ & Ilha do Prumirim & Ilha do Prumirim & $\begin{array}{l}\text { Baixo interesse } \\
\text { geocientífico }\end{array}$ \\
\hline $495564 / 7409580$ & Praia da Almada & Baixo interesse geocientífico & - \\
\hline $475133 / 7399074$ & Cachoeira da Renata & Cachoeira da Renata & $\begin{array}{l}\text { Baixo interesse } \\
\text { geocientífico }\end{array}$ \\
\hline $507473 / 7417537$ & Esporão da Puruba & Esporão da Puruba & Esporão da Puruba \\
\hline $473995 / 7391181$ & Praia da Lagoa & Praia da Lagoa & Praia da Lagoa \\
\hline $472885 / 7391365$ & Praia Ponta Aguda & Dificuldade de acesso & - \\
\hline $512340 / 7416288$ & Praia das Conchas & Praia das Conchas & Praia das Conchas \\
\hline
\end{tabular}

Tabela 3 Processo seletivo dos sítios da geodiversidade no município de Caraguatatuba.

\begin{tabular}{|c|c|c|c|}
\hline $\begin{array}{c}\text { Coordenadas } \\
\text { (UTM) }\end{array}$ & Pré-Seleção & Seleção Parcial & Seleção Final \\
\hline $456457 / 7378095$ & Foz do rio Juqueriquerê & Foz do rio Juqueriquerê & Foz do rio Juqueriquerê \\
\hline $462063 / 7390289$ & Pedreira Massaguaçu & Pedreira Massaguaçu & Pedreira Massaguaçu \\
\hline $463557 / 7387551$ & Lagoa Azul & Lagoa Azul & Lagoa Azul \\
\hline $457954 / 7387545$ & Gnaisse da Paróquia Santo Antônio & $\begin{array}{c}\text { Gnaisse da Paróquia Santo } \\
\text { Antônio }\end{array}$ & $\begin{array}{c}\text { Gnaisse da Paróquia } \\
\text { Santo Antônio }\end{array}$ \\
\hline $456129 / 7391066$ & Veios dobrados da Trilha do Jequitibá & $\begin{array}{c}\text { Veios dobrados da Trilha do } \\
\text { Jequitibá }\end{array}$ & $\begin{array}{c}\text { Veios dobrados da Trilha } \\
\text { do Jequitibá }\end{array}$ \\
\hline $468571 / 7392686$ & Granitos da Praia da Mococa & Granitos da Praia da Mococa & $\begin{array}{c}\text { Granitos da Praia da } \\
\text { Mococa }\end{array}$ \\
\hline
\end{tabular}


Tabela 4 Processo seletivo dos sítios da geodiversidade no município de Ilhabela.

\begin{tabular}{|c|c|c|c|}
\hline $\begin{array}{l}\text { Coordenadas } \\
\text { (UTM) }\end{array}$ & Pré-Seleção & Seleção Parcial & Seleção Final \\
\hline $459197 / 7363413$ & Praia do Oscar & Praia do Oscar & Praia do Oscar \\
\hline $463030 / 7363953$ & Cachoeira da Água Branca & Cachoeira da Água Branca & $\begin{array}{l}\text { Baixo interesse } \\
\text { geocientífico }\end{array}$ \\
\hline $467655 / 7376027$ & Praia da Pacuíba & Baixo interesse geocientífico & - \\
\hline $463591 / 7363166$ & Trilha da Água Branca & Trilha da Água Branca & Trilha da Água Branca \\
\hline $464329 / 7373175$ & Diques da Siriúba & Diques da Siriúba & Diques da Siriúba \\
\hline $465235 / 7364948$ & Cachoeira da Toca & Cachoeira da Toca & Cachoeira da Toca \\
\hline $463233 / 7364176$ & Gruta da Cachoeira da Água Branca & $\begin{array}{c}\text { Gruta da Cachoeira da Água } \\
\text { Branca }\end{array}$ & $\begin{array}{c}\text { Baixo interesse } \\
\text { geocientífico }\end{array}$ \\
\hline $458415 / 7352775$ & Lago Dourado & Lago Dourado & Lago Dourado \\
\hline $461433 / 7353646$ & Cachoeira do Areado & Dificuldade de acesso & - \\
\hline $467016 / 7362012$ & Ponto do Chuveirinho & Baixo interesse geocientífico & - \\
\hline $463518 / 7354138$ & Mirante do Bonete & Baixo interesse geocientifico & - \\
\hline $464840 / 7354858$ & Praia do Bonete & Baixo interesse geocientifico & - \\
\hline $456059 / 7358413$ & Cachoeira do Veloso & Cachoeira do Veloso & $\begin{array}{l}\text { Baixo interesse } \\
\text { geocientífico }\end{array}$ \\
\hline $466718 / 7372359$ & Cachoeira da Friagem / Couro de Boi & $\begin{array}{c}\text { Cachoeira da Friagem / Couro } \\
\text { de Boi }\end{array}$ & Dificuldade de acesso \\
\hline $458348 / 7353222$ & Cachoeira da Lage & Cachoeira da Laje & Cachoeira da Laje \\
\hline $458691 / 7361862$ & Cachoeira dos Três tombos & Dificuldade de acesso & - \\
\hline $460970 / 7360494$ & Pico de São Sebastião & Pico de São Sebastião & Pico de São Sebastião \\
\hline $470686 / 7362033$ & Praia dos Castelhanos & Praia dos Castelhanos & Praia dos Castelhanos \\
\hline
\end{tabular}

*Em cinza escuro o principal motivo que levou à eliminação do sítio.

Tabela 5 Processo seletivo dos sítios da geodiversidade no município de São Sebastião.

\begin{tabular}{|c|c|c|c|}
\hline $\begin{array}{c}\text { Coordenadas } \\
\text { (UTM) }\end{array}$ & Pré-Seleção & Seleção Parcial & Seleção Final \\
\hline $437176 / 7374563$ & Dique da Cachoeira do Cambury & $\begin{array}{c}\text { Dique da Cachoeira do } \\
\text { Cambury }\end{array}$ & $\begin{array}{c}\text { Dique da Cachoeira do } \\
\text { Cambury }\end{array}$ \\
\hline $437734 / 7368013$ & Praia Brava & Praia Brava & Praia Brava \\
\hline $450228 / 7370399$ & Praia da Baleia & Baixo interesse geocientífico & - \\
\hline $453987 / 7365134$ & Toca do Buraco do bicho & Baixo interesse geocientífico & - \\
\hline $446890 / 7364340$ & Tômbolo das Calhetas & Tômbolo das Calhetas & Tômbolo das Calhetas \\
\hline $422916 / 7371574$ & Mirante Barra do Una & Mirante Barra do Una & Mirante Barra do Una \\
\hline $438199 / 7371938$ & Cachoeira Ribeirão do Itu & Cachoeira Ribeirão do Itu & $\begin{array}{c}\text { Baixo interesse } \\
\text { geocientífico }\end{array}$ \\
\hline $450048 / 7365514$ & Trilha do Guaecá & Trilha do Guaecá & Dificuldade de acesso \\
\hline $454507 / 7364791$ & Costão norte da Praia do Guaecá & $\begin{array}{c}\text { Costão norte da Praia do } \\
\text { Guaecá }\end{array}$ & Dificuldade de acesso \\
\hline $444942 / 7366566$ & Praia do Santiago & Baixo interesse geocientífico & - \\
\hline $452278 / 7365705$ & Mirante do Paúba & Mirante do Paúba & $\begin{array}{c}\text { Baixo interesse } \\
\text { geocientífico }\end{array}$ \\
\hline $455052 / 7364850$ & Intrusões Máficas de Barequeçaba & $\begin{array}{c}\text { Intrusões Máficas de } \\
\text { Barequeçaba }\end{array}$ & $\begin{array}{c}\text { Intrusões Máficas de } \\
\text { Barequeçaba }\end{array}$ \\
\hline
\end{tabular}

*Em cinza escuro o principal motivo que levou à eliminação do sítio. 
Os principais requisitos para a eliminação dos sítios pré-selecionados foram a dificuldade de acesso e o baixo interesse geocientífico. Sete sítios foram eliminados devido à dificuldade de acesso, o que inclui aspectos como costões muito íngremes, trilhas muito fechadas ou sítios localizados dentro de área particular, além de baixa segurança e limitações de uso. Os demais (23 sítios) foram eliminados em virtude do baixo interesse geocientífico, que inclui baixo potencial didático e/ou interpretativo e elementos geológicos recorrentes na área de estudo.

\subsubsection{Avaliação quantitativa}

Os 25 sítios da geodiversidade selecionados foram avaliados quantitativamente por meio da plataforma GEOSSIT (CPRM, 2016), desenvolvida pelo Serviço Geológico do Brasil. A plataforma foi inicialmente desenvolvida com base nos métodos de Brilha (2005) e Garcia-Cortés \& Urqui (2009) e recentemente reestruturada com adaptações ao método de Brilha (2016). Cabe destacar que, de acordo com o GEOSSIT, um local é classificado como geossítio se o seu valor científico for igual ou maior a 200, enquanto valores menores que 200 o classificam como sítio da geodiversidade. A plataforma permite a avaliação quantitativa do valor científico (geossítios), potencial de uso educativo e de uso turístico (sítios da geodiversidade) e risco de degradação. Os potenciais de uso educativo e turístico podem ser quantificados em ambos os casos: geossítios e sítios da geodiversidade.

Os potenciais de uso educativo e turístico são avaliados através de 15 parâmetros, aos quais podem ser atribuídos valores de 0 a 4. Para o risco de degradação são avaliados 5 parâmetros, que podem ser valorados de 0 a 4 . Cada critério de avaliação possui um peso (\%) e no final é feita a soma ponderada dos valores de acordo com o peso de cada critério.

Após a seleção e quantificação, os sítios foram classificados de acordo com o potencial de uso educativo e/ou turístico com valores altos e muito altos. Visto que todos os sítios da geodiversidade obrigatoriamente devem ter um alto potencial turístico e educativo, os valores obtidos foram classificados em altos, para valores de até 300 e muito altos, para valores acima de 300 . 


\section{Resultados}

A partir do inventário dos sítios com potencial para o uso turístico e educativo, chegou-se ao total de 25 sítios da geodiversidade distribuídos ao longo do litoral norte do estado de São Paulo (Figura 3).

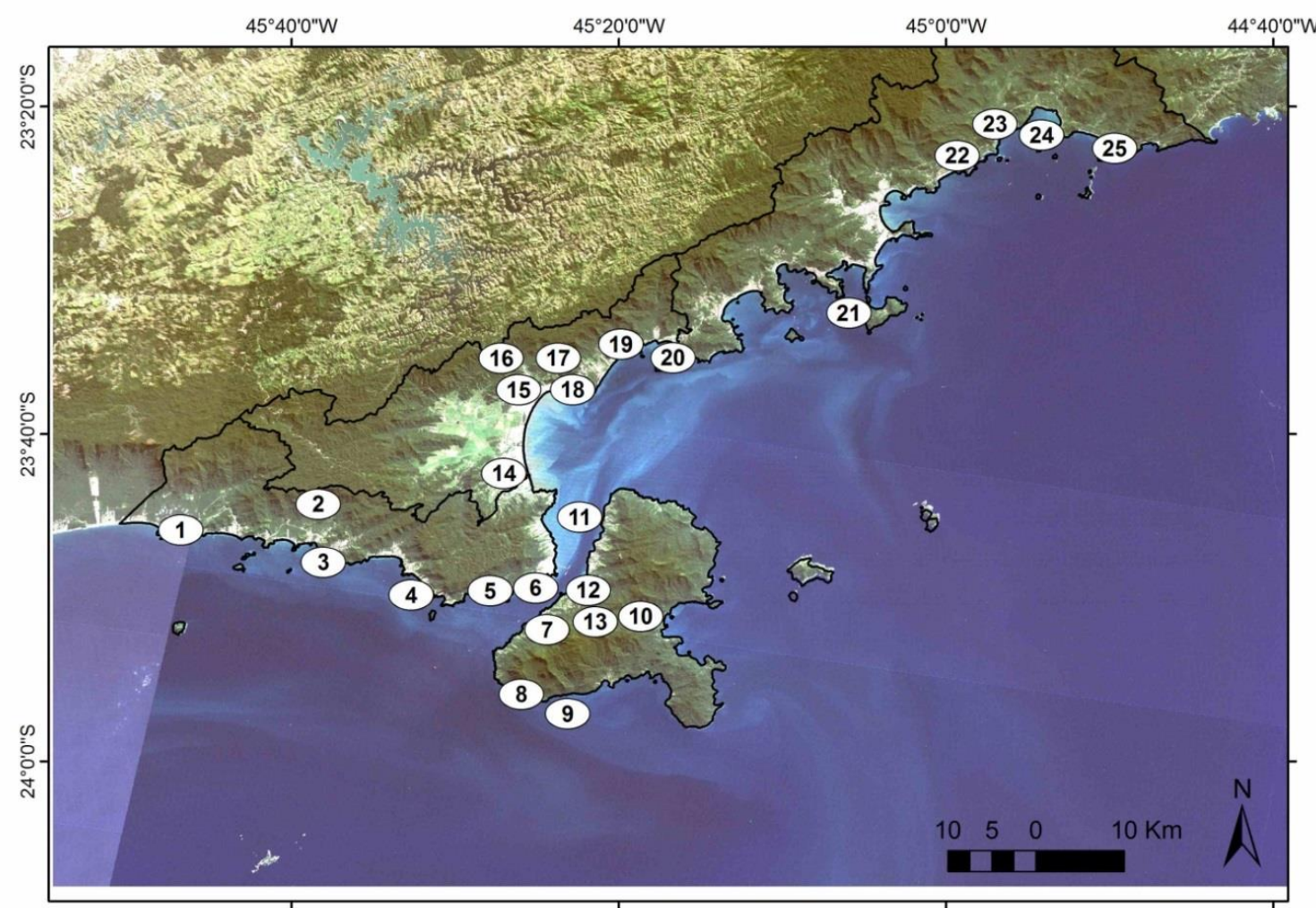

Figura 3 Mapa de localização dos sítios da geodiversidade no litoral norte de São Paulo. 1 Mirante Barra do Una; 2 - Dique da Cachoeira do Cambury; 3 - Praia Brava; 4 - Tômbolo das Calhetas; 5 - Intrusões Máficas de Barequeçaba; 6 - Praia do Oscar; 7 - Pico de São Sebastião; 8 - Cachoeira da Laje; 9 - Lago Dourado; 10 - Praia dos Castelhanos; 11 - Diques da Siriúba; 12 - Cachoeira da Toca; 13 - Trilha da Água Branca; 14 - Foz do Rio Juqueriquerê; 15 Gnaisse da Paróquia Santo Antônio; 16 - Veios Dobrados da Trilha Jequitibá; 17 - Pedreira Massaguaçu; 18 - Lagoa Azul; 19 - Granitos da Mococa; 20 - Praia da Lagoa; 21 - Mirante do Engenho; 22 - Charnockito da Cachoeira do Prumirim; 23 - Esporão da Puruba; 24 - Praia das Conchas; 25 - Praia da Fazenda.

\subsection{Descrição dos sítios da geodiversidade}

\subsubsection{Município de São Sebastião}

No município de São Sebastião estão presentes as unidades geológicas do Complexo Gnáissico Migmatítico, o Granito Guaecá, o Granito Pico do Papagaio e Augen Gnaisse Juquehy (Perrotta et al., 2005). A região apresenta ainda, protomilonitos a ultramilonitos (Maffra, 2000) associados à Zona de Cisalhamento Camburu, que atravessa o município. 
Neste município foram inventariados cinco sítios da geodiversidade (Tabela 6), onde dois deles contam a história geológica do momento da fragmentação do Supercontinente Gondwana Ocidental, quais sejam: Diques da Cachoeira do Cambury e Intrusões Máficas de Barequeçaba. Os demais sítios: Mirante da Barra do Una, Praia Brava e Tômbolo das Calhetas contextualizam a Era Cenozoica, com feições geomorfológicas erosicionais e deposicionais como principais elementos geológicos do sítio.

Tabela 6 Descrição dos sítios da geodiversidade inventariados no município de São Sebastião.

\begin{tabular}{|c|c|c|c|c|}
\hline $\begin{array}{c}\text { Sítio da } \\
\text { Geodiversidade }\end{array}$ & Acesso & $\begin{array}{l}\text { Unidade } \\
\text { litoestratigráfica } \\
\text { (Perrotta et al., } \\
\text { 2005) }\end{array}$ & Descrição geológica & $\begin{array}{c}\text { Feições da } \\
\text { Geodiversidade com } \\
\text { potencial para uso } \\
\text { educacional e/ou } \\
\text { turístico }\end{array}$ \\
\hline $\begin{array}{c}\text { Dique da } \\
\text { Cachoeira do } \\
\text { Cambury }\end{array}$ & $\begin{array}{l}\text { 2a cachoeira da Trilha } \\
\text { do Sertão do Cambury } \\
\text { (Figura 4A). Acesso à } \\
\text { trilha pelo lado } \\
\text { morro, próximo à } \\
\text { praia de Camburi. }\end{array}$ & $\begin{array}{l}\text { Complexo } \\
\text { Costeiro, unidade } \\
\text { de gnaisses } \\
\text { peraluminosos. }\end{array}$ & $\begin{array}{c}\text { Dique básico com orientação NE } \\
\text { e cerca de } 10 \mathrm{~m} \text { de espessura } \\
\text { encaixado em paragnaisse. A } \\
\text { queda da cachoeira ocorre } \\
\text { diretamente sobre o dique. } \\
\text { Blocos transportados de } \\
\text { tamanhos variados dispostos na } \\
\text { área. }\end{array}$ & $\begin{array}{c}\text { - Fragmentação do } \\
\text { Gondwana; } \\
\text { - Transporte e deposição } \\
\text { de sedimentos; } \\
\text { - Intemperismo no } \\
\text { dique. }\end{array}$ \\
\hline Praia Brava & $\begin{array}{l}\text { Através de trilha } \\
\text { dentro do Parque } \\
\text { Estadual da Serra do } \\
\text { Mar (Núcleo São } \\
\text { Sebastião): Seguir } \\
\text { pela Rodovia SP-55 } \\
\text { até o Km 162,5, } \\
\text { sentido centro de São } \\
\text { Sebastião, onde há } \\
\text { uma bifurcação com } \\
\text { uma placa indicativa } \\
\text { da mesma. }\end{array}$ & $\begin{array}{l}\text { Complexo } \\
\text { Costeiro, unidade } \\
\text { de gnaisses } \\
\text { peraluminosos. }\end{array}$ & $\begin{array}{c}\text { Ponto de deságue do Rio } \\
\text { Boiçucanga; } \\
\text { Presença de blocos de diversos } \\
\text { tamanhos trazidos pelo rio } \\
\text { (Figura 4B); } \\
\text { Camadas estratificadas na areia à } \\
\text { margem do rio; } \\
\text { Marcas de ondas são observadas } \\
\text { tanto na areia (com depósito de } \\
\text { minerais), como dentro do rio } \\
\text { (fluxo de água); } \\
\text { Costões formados por biotita } \\
\text { gnaisse bandado com enclaves } \\
\text { félsicos mais recentes. }\end{array}$ & $\begin{array}{l}\text { - Dinâmica costeira; } \\
\text { - Transporte e deposição } \\
\text { de blocos pelo rio e de } \\
\text { minerais pesados; } \\
\text { - Deformação da rocha } \\
\text { em ambos costões, com } \\
\text { presença de biotita e } \\
\text { enclaves recentes, que } \\
\text { estabelecem correlação } \\
\text { temporal. }\end{array}$ \\
\hline $\begin{array}{l}\text { Tômbolo das } \\
\text { Calhetas }\end{array}$ & $\begin{array}{c}\text { O acesso próximo ao } \\
\text { Km } 144 \text { é feito por um } \\
\text { condomínio, onde não } \\
\text { é permitida a entrada } \\
\text { de veículos. A partir } \\
\text { da portaria, são dez } \\
\text { minutos de } \\
\text { caminhada até a } \\
\text { praia. }\end{array}$ & $\begin{array}{l}\text { Complexo } \\
\text { Costeiro, unidade } \\
\text { de gnaisses } \\
\text { peraluminosos. }\end{array}$ & $\begin{array}{l}\text { Ilhote unido por um tômbolo } \\
\text { (Figura 4C); } \\
\text { A rocha corresponde a um } \\
\text { granada-biotita gnaisse com } \\
\text { intrusões pegmatíticas; } \\
\text { Costões com presença de dobras } \\
\text { intrafoliais e boudins. }\end{array}$ & $\begin{array}{l}\text { - Presença do tômbolo; } \\
\text { - Dinâmica costeira } \\
\text { (Figura 4D); } \\
\text { - Deformação da rocha, } \\
\text { com exemplos das } \\
\text { dobras intrafoliais; } \\
\text { Amalgamação (boudins). }\end{array}$ \\
\hline $\begin{array}{c}\text { Mirante da Barra } \\
\text { do Una }\end{array}$ & $\begin{array}{l}\text { Em frente à sede do } \\
\text { Parque Estadual da } \\
\text { Serra do Mar - Núcleo } \\
\text { São Sebastião. Acesso } \\
\text { pela praia de Juquehy, } \\
\text { sentido Barra do Una. }\end{array}$ & $\begin{array}{c}\text { Depósitos } \\
\text { litorâneos } \\
\text { indiferenciados. }\end{array}$ & $\begin{array}{l}\text { Ponto de observação da Praia da } \\
\text { Barra do Una (Figura 4E); } \\
\text { Praia possui uma barra que } \\
\text { separa o mar do Rio Una. }\end{array}$ & $\begin{array}{l}\text { - Presença da barra } \\
\text { costeira; } \\
\text { - Deságue do Rio Una; } \\
\text { - Encontro do Rio Una } \\
\text { com o mar. }\end{array}$ \\
\hline $\begin{array}{l}\text { Intrusões Máficas } \\
\text { de Barequeçaba }\end{array}$ & $\begin{array}{l}\text { Costão sul da praia de } \\
\text { Barequeçaba, com } \\
\text { fácil acesso através da } \\
\text { rodovia Rio-Santos. }\end{array}$ & $\begin{array}{l}\text { Granito São } \\
\text { Sebastião. }\end{array}$ & $\begin{array}{c}\text { Granito foliado com a presença } \\
\text { de granada; } \\
\text { Presença de minerais máficos } \\
\text { (biotita), que dão orientação à } \\
\text { rocha (devido à estrutura } \\
\text { placóide); } \\
\text { Presença de dique concordante à } \\
\text { foliação da rocha; } \\
\text { Presença de extenso sill } \\
\text { observado do início do costão } \\
\text { (Figura 4F). }\end{array}$ & $\begin{array}{l}\text { - Intrusões máficas } \\
\text { decorrentes da } \\
\text { fragmentação do } \\
\text { Gondwana. }\end{array}$ \\
\hline
\end{tabular}



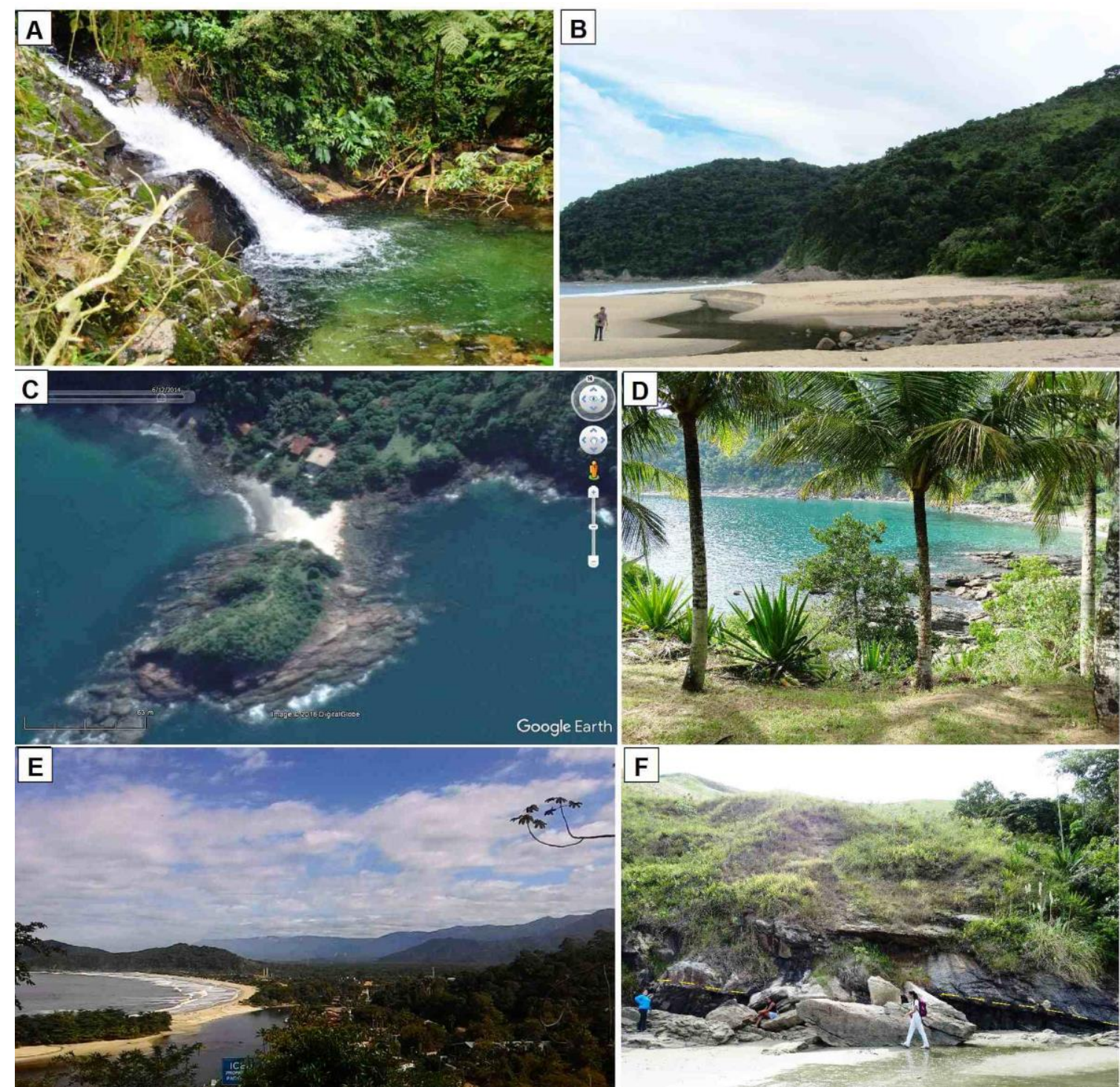

Figura 4 Sítios da geodiversidade no município de São Sebastião. A) Dique da Cachoeira do Cambury; B) Praia Brava, mostrando os blocos transportados ao longo do rio; C) Tômbolo das Calhetas, imagem de satélite demonstrando o tômbolo de areia interligando o ilhote ao continente. Fonte: Google Earth; D) Tômbolo das Calhetas, vista obtida a partir do mirante localizado no topo do ilhote; E) Mirante da Barra do Una, a partir do mirante pode-se observar a barra arenosa que divide o rio Una do Oceano e a Serra do Mar ao fundo (Foto: Ricardo Romero); F) Intrusões Máficas de Barequeçaba, na porção inferior do afloramento é possível observar a presença de um sill.

\subsubsection{Município de Ilhabela}

Ilhabela constitui-se em uma ilha separada do continente durante o Cretáceo Inferior, apresentando embasamento cristalino neoproterozoico. Afloram granitognaisses grossos, biotita gnaisses, gnaisses bandados, rochas calciossilicáticas, granitos porfiríticos foliados, gnaisses migmatíticos milonitizados e álcali sienitos (Barreto, 2012). A geologia da ilha resulta do magmatismo alcalino ocorrido no Cretáceo 
Superior, decorrente da reativação de zonas de falhas durante a abertura do Atlântico Sul, formando três grandes stocks de rochas sieníticas que caracterizam o relevo acidentado local, denominados picos da Serraria (ao norte), Mirante (a sudeste) e São Sebastião (a sudoeste).

No município de Ilhabela foram selecionados 8 sítios da geodiversidade (Tabela 7), sendo um deles constituído por 5 pontos - a Trilha da Água Branca, que consiste em uma trilha que passa por cinco poços com queda d'água apresentando estruturas e feições geológicas que vão desde intrusões de diques à intemperismo e transporte de blocos.

Tabela 7 Descrição dos sítios da geodiversidade inventariados no município de Ilhabela.

\begin{tabular}{|c|c|c|c|c|}
\hline $\begin{array}{c}\text { Sítio da } \\
\text { Geodiversidade }\end{array}$ & Acesso & $\begin{array}{l}\text { Unidade } \\
\text { litoestratigráfica } \\
\text { (Perrotta et al. } \\
\text { 2005) }\end{array}$ & Descrição geológica & $\begin{array}{c}\text { Feições da } \\
\text { Geodiversidade com } \\
\text { potencial para uso } \\
\text { educacional e/ou turístico }\end{array}$ \\
\hline Praia do Oscar & $\begin{array}{l}\text { Av. Brasil, bairro do } \\
\text { Portinho. Possui placas } \\
\text { indicativas. }\end{array}$ & $\begin{array}{l}\text { Unidade } \\
\text { ortognáissica. }\end{array}$ & $\begin{array}{c}\text { Costão de gnaisse granítico } \\
\text { posicionado paralelamente à linha } \\
\text { de praia, com presença de injeções } \\
\text { félsicas dobradas e fraturas por } \\
\text { vezes preenchidas por diques de } \\
\text { diabásio (Figura } 5 \mathrm{~A} \text { ). }\end{array}$ & $\begin{array}{l}\text { - Intrusões de diques de } \\
\text { diabásio; } \\
\text { - Injeções félsicas no } \\
\text { gnaisse deformado. }\end{array}$ \\
\hline $\begin{array}{c}\text { Trilha da Água } \\
\text { Branca }\end{array}$ & $\begin{array}{l}\text { Acesso pela guarita do } \\
\text { Parque Estadual de } \\
\text { Ilhabela, na Estrada de } \\
\text { Castelhanos. }\end{array}$ & $\begin{array}{l}\text { Complexos } \\
\text { plutônicos } \\
\text { alcalinos: São } \\
\text { Sebastião. }\end{array}$ & $\begin{array}{l}\text { O poço da Pedra é formado por } \\
\text { granito porfirítico deformado; no } \\
\text { Poço da Escada há dois blocos } \\
\text { separados por fraturas que foram } \\
\text { preenchidas por diques (Figura 5B); } \\
\text { o Poço da Ducha possui a queda } \\
\text { controlada por fratura e grande } \\
\text { quantidade de blocos; no Poço do } \\
\text { Jequitibá o Rio da Água Branca } \\
\text { segue a direção das fraturas da } \\
\text { rocha; e no Poço do Jabuti há } \\
\text { presença de grande quantidade de } \\
\text { matacões no leito do rio. }\end{array}$ & $\begin{array}{l}\text { - Fraturas e formação de } \\
\text { blocos; } \\
\text { - Intrusões de diques; } \\
\text { - Intemperismo das rochas } \\
\text { e formação de solos. }\end{array}$ \\
\hline $\begin{array}{l}\text { Diques da } \\
\text { Siriúba }\end{array}$ & $\begin{array}{l}\text { Av. Leonardo Reale, } \\
3026 \text { - Siriúba. }\end{array}$ & $\begin{array}{l}\text { Unidade granito } \\
\text { gnáissica } \\
\text { migmatítica. }\end{array}$ & $\begin{array}{l}\text { Costão composto por rocha } \\
\text { gnáissica (Figura } 5 \mathrm{C} \text { ) e diques de } \\
\text { diabásio e lamprófiro. } \\
\text { Os diques apresentam esfoliação } \\
\text { esferoidal. }\end{array}$ & $\begin{array}{l}\text { - Intrusão de diques; } \\
\text { - Relações entre cortantes } \\
\text { das famílias de juntas; } \\
\text { - Erosão esferoidal. }\end{array}$ \\
\hline $\begin{array}{c}\text { Cachoeira da } \\
\text { Toca }\end{array}$ & Estrada da Toca, 1000. & $\begin{array}{l}\text { Complexos } \\
\text { plutônicos } \\
\text { alcalinos: São } \\
\text { Sebastião. }\end{array}$ & $\begin{array}{l}\text { Granito porfirítico milonítico com } \\
\text { fenocristais de feldspato potássico } \\
\text { e presença de dique de lamprófiro } \\
\text { (Figura 5D). }\end{array}$ & $\begin{array}{l}\text { - Deformação dos } \\
\text { minerais; } \\
\text { - Intrusão de diques de } \\
\text { lamprófiro. }\end{array}$ \\
\hline Lago Dourado & $\begin{array}{c}\text { Acesso pela Trilha do } \\
\text { Bonete, } 3 \mathrm{~km} \text { da Ponta } \\
\text { de Sepituba. }\end{array}$ & $\begin{array}{l}\text { Complexos } \\
\text { plutônicos } \\
\text { alcalinos: São } \\
\text { Sebastião. }\end{array}$ & $\begin{array}{l}\text { Lago com alta presença de } \\
\text { vermiculita em suspensão (Figura } \\
\text { 5E), decorrente da biotita alterada } \\
\text { proveniente do nefelina sienito do } \\
\text { maciço de São Sebastião. }\end{array}$ & $\begin{array}{l}\text { - Sedimentos de } \\
\text { vermiculita de coloração } \\
\text { amarelada que em } \\
\text { suspensão na água dá ao } \\
\text { lago um aspecto dourado. }\end{array}$ \\
\hline $\begin{array}{l}\text { Cachoeira da } \\
\text { Laje }\end{array}$ & $\begin{array}{c}\text { Acesso pela Trilha do } \\
\text { Bonete, } 3 \mathrm{~km} \text { da Ponta } \\
\text { de Sepituba. }\end{array}$ & $\begin{array}{l}\text { Complexos } \\
\text { plutônicos } \\
\text { alcalinos: São } \\
\text { Sebastião. }\end{array}$ & $\begin{array}{l}\text { Laje de sienito com presença de } \\
\text { blocos fraturados e intemperizados } \\
\text { (Figura } 5 F \text { ). } \\
\text { Localmente há enclaves máficos. }\end{array}$ & $\begin{array}{l}\text { - Presença de uma "escada } \\
\text { natural" no afloramento } \\
\text { seguindo os planos de } \\
\text { fratura da rocha. }\end{array}$ \\
\hline
\end{tabular}




\begin{tabular}{|c|c|c|c|c|}
\hline $\begin{array}{l}\text { Pico de São } \\
\text { Sebastião }\end{array}$ & $\begin{array}{c}\text { Trilha do Pico de São } \\
\text { Sebastião, acesso pela } \\
\text { Av. Riachuelo. }\end{array}$ & $\begin{array}{l}\text { Complexos } \\
\text { plutônicos } \\
\text { alcalinos: São } \\
\text { Sebastião. }\end{array}$ & Pico constituído de rocha sienítica. & $\begin{array}{l}\text { - Ponto mais alto de } \\
\text { Ilhabela (Figura } 5 G \text { ), onde } \\
\text { é possível observar feições } \\
\text { geomorfológicas da Serra } \\
\text { do Mar e do Canal de São } \\
\text { Sebastião. }\end{array}$ \\
\hline $\begin{array}{l}\text { Praia dos } \\
\text { Castelhanos }\end{array}$ & $\begin{array}{l}\text { Acesso pela Estrada de } \\
\text { Castelhanos ( } 22 \mathrm{~km} \text { de } \\
\text { estrada de terra batida). }\end{array}$ & $\begin{array}{l}\text { Unidade granito } \\
\text { gnáissica } \\
\text { migmatítica. }\end{array}$ & $\begin{array}{c}\text { Praia com presença de um esporão } \\
\text { cuspidado (em formato triângular) } \\
\text { (Figura 5H); } \\
\text { Costão sul constituído por granito } \\
\text { porfirítico foliado com a presença } \\
\text { de blocos com veios félsicos, } \\
\text { alguns com esfoliação esferoidal. } \\
\text { Costão norte constituído por } \\
\text { blocos de granito porfirítico com } \\
\text { intercalações de rocha máfica } \\
\text { porfirítica. }\end{array}$ & $\begin{array}{c}\text { - Espirão cuspidado } \\
\text { (formato triângular) na } \\
\text { areia da Praia dos } \\
\text { Castelhanos decorrente da } \\
\text { barreira imposta por um } \\
\text { ilhote; } \\
\text { - Granitos porfiríticos dos } \\
\text { costões norte e sul da } \\
\text { praia. }\end{array}$ \\
\hline
\end{tabular}

Os sítios Praia do Oscar, Diques da Siriúba e Cachoeira da Toca estão diretamente relacionados ao evento de fragmentação do supercontinente Gondwana. Enquanto os sítios Lago Dourado, Pico de São Sebastião e Praia dos Castelhanos abordam eventos geológicos mais recentes, ocorridos na Era Cenozoica.

\subsubsection{Município de Caraguatatuba}

Em Caraguatatuba, grande parte do município está geologicamente inserido na unidade granito gnáissica migmatítica, conhecida como Complexo Pico do Papagaio, que aflora principalmente como hornblenda-biotita granito porfirítico, na cor cinzarosada, podendo apresentar deformações quando associado a zonas de cisalhamento. As praias do município correspondem a depósitos quaternários divididos em detríticos ou litorâneos, com predomínio de areia, silte e argila (Perrotta et al., 2005).

Neste município foram selecionados 6 sítios da geodiversidade (Tabela 8), onde um deles consiste em uma mineração ativa, a "Pedreira Massaguaçu", que exibe processos geológicos de ambientes rúptil e dúctil. O sítio "Veios Dobrados da Trilha do Jequitibá" consiste em um afloramento localizado em uma trilha apresentando feições características do evento de amalgamação dos continentes.

O sítio "Granitos da Mococa" apresenta diques e veios com megacristais de quartzo referentes ao período de fragmentação do supercontinente Gondwana, assim como o sítio "Gnaisse da Paróquia Santo Antônio", apresentando intrusões de rocha gnáissica de granulação mais fina. Já os sítios Foz do Rio Juqueriquerê e Lagoa Azul apresentam feições geomorfológicas recentes associadas à deposição de sedimentos na foz de seus respectivos rios. 

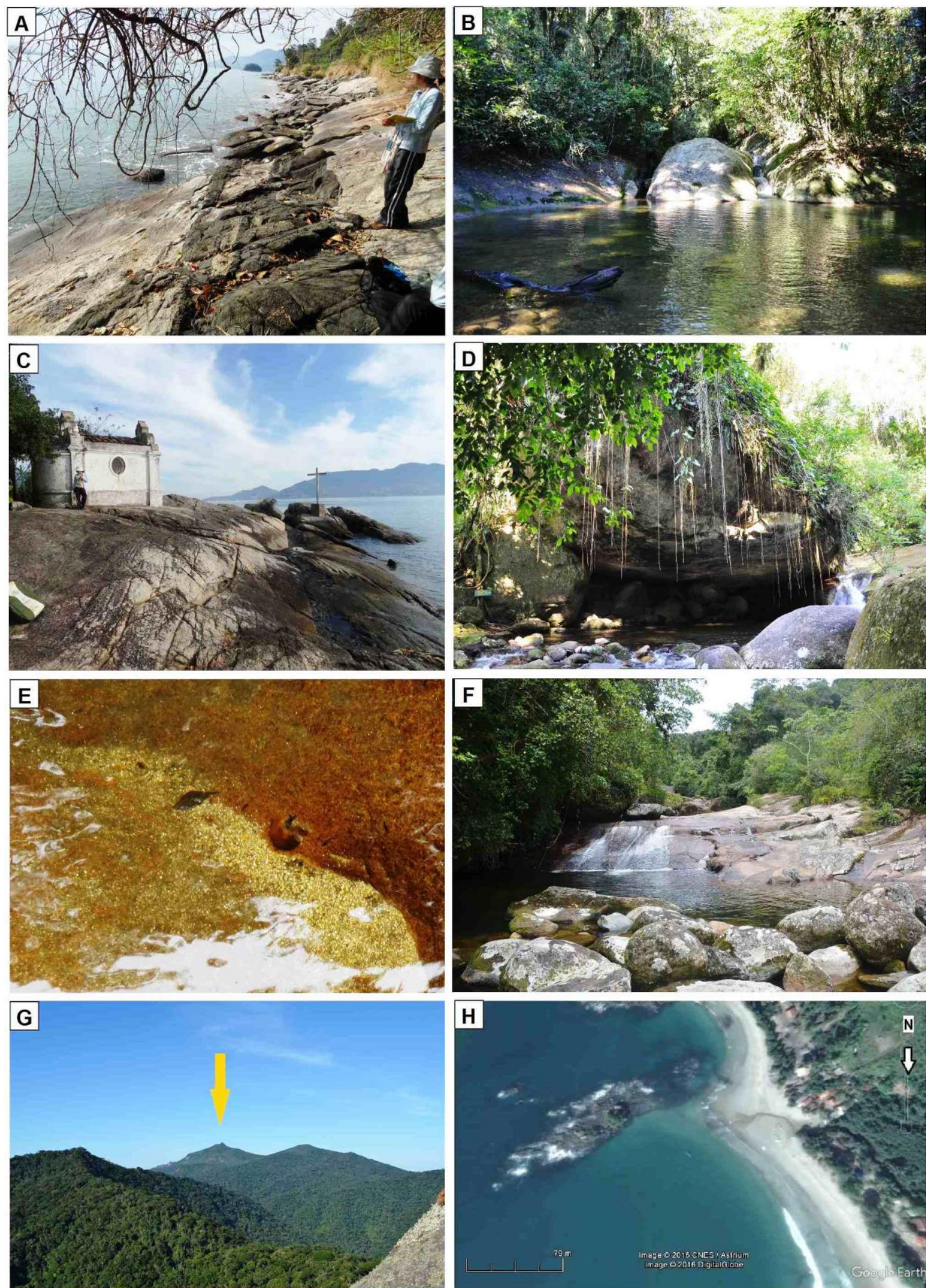

Figura 5 Sítios da geodiversidade no município de Ilhabela. A) Praia do Oscar, dique máfico exposto em um dos costões da praia; B) Trilha da Água Branca, Poço da Escada; C) Diques da Siriúba; D) Cachoeira da Toca; E) Lago Dourado, com destaque para a concentração de vermiculita no fundo do lago, fornecendo ao lago um aspecto dourado; F) Cachoeira da Laje; G) Pico de São Sebastião (em destaque abaixo da seta amarela), visto a partir do Pico do Baepi; H) Praia dos Castelhanos, Fonte: Google Earth. 
Tabela 8 Descrição dos sítios da geodiversidade inventariados no município de Caraguatatuba.

\begin{tabular}{|c|c|c|c|c|}
\hline $\begin{array}{c}\text { Sítio da } \\
\text { Geodiversidade }\end{array}$ & Acesso & $\begin{array}{c}\text { Unidade } \\
\text { litoestratigráfica } \\
\text { (Perrotta et al. } \\
\text { 2005) }\end{array}$ & Descrição geológica & $\begin{array}{c}\text { Feições da } \\
\text { Geodiversidade com } \\
\text { potencial para uso } \\
\text { educacional e/ou turístico }\end{array}$ \\
\hline $\begin{array}{l}\text { Foz do Rio } \\
\text { Juqueriquerê }\end{array}$ & $\begin{array}{l}\text { BR-101 no Bairro } \\
\text { Porto Novo, Av. } \\
\text { Geraldo Nogueira da } \\
\text { Silva (sentido sul). }\end{array}$ & $\begin{array}{l}\text { Depósitos } \\
\text { litorâneos. }\end{array}$ & $\begin{array}{l}\text { Foz em delta do Rio Juqueriquerê } \\
\text { com presença de deposição de } \\
\text { sedimentos fluviais (Figura 6A). }\end{array}$ & $\begin{array}{l}\text { - Tipos de foz; } \\
\text { - Transporte e deposição } \\
\text { de sedimentos fluviais. }\end{array}$ \\
\hline $\begin{array}{c}\text { Pedreira } \\
\text { Massaguaçu }\end{array}$ & $\begin{array}{l}\text { BR-101 no Bairro de } \\
\text { Jardim Olaria. }\end{array}$ & $\begin{array}{l}\text { Complexo granítico } \\
\text { Pico do Papagaio. }\end{array}$ & $\begin{array}{c}\text { Mineração ativa (Figura 6B); } \\
\text { Rochas gnáissicas com } \\
\text { bandamentos bem marcados; } \\
\text { Presença de diques máficos; } \\
\text { Paredão rochoso contendo } \\
\text { indicadores cinemáticos de } \\
\text { movimento sinestral. } \\
\end{array}$ & $\begin{array}{l}\text { - Processo de mineração; } \\
\text { - Comportamento } \\
\text { mecânico das rochas em } \\
\text { ambiente rúptil: dique e } \\
\text { falha. }\end{array}$ \\
\hline Lagoa Azul & $\begin{array}{l}\text { Limite sul da Praia do } \\
\text { Capricórnio, Bairro do } \\
\text { Capricórnio, pela } \\
\text { Rodovia Rio-Santos. }\end{array}$ & $\begin{array}{l}\text { Complexo granítico } \\
\text { Pico do Papagaio/ } \\
\text { Depósitos } \\
\text { litorâneos. }\end{array}$ & $\begin{array}{l}\text { Foz do rio Capricórnio com } \\
\text { presença de uma barra fluvial } \\
\text { paralela à linha de costa (Figura } \\
6 C \text { ); Granulometria diferenciada do } \\
\text { resto da Praia (mais grossa); Praia } \\
\text { inclinada com presença de bermas } \\
\text { de até } 1 \mathrm{~m} \text { de altura. }\end{array}$ & $\begin{array}{l}\text { - Tipos de foz; } \\
\text { - Transporte e deposição } \\
\text { dos sedimentos; } \\
\text { - Granulometria e } \\
\text { composição da areia. }\end{array}$ \\
\hline $\begin{array}{l}\text { Gnaisse da } \\
\text { Paróquia Santo } \\
\text { Antônio }\end{array}$ & $\begin{array}{l}\text { Afloramento dentro } \\
\text { da Paróquia Santo } \\
\text { Antônio, na Praça } \\
\text { Cândido Mota, no 35, } \\
\text { Centro. }\end{array}$ & $\begin{array}{l}\text { Complexo granítico } \\
\text { Pico do Papagaio. }\end{array}$ & $\begin{array}{l}\text { Afloramento de gnaisse granítico } \\
\text { milonítico com granulação grossa } \\
\text { (Figura } 8 \mathrm{D} \text { ), bastante estirado, com } \\
\text { cerca de } 3 \text { m de diâmetro, } \\
\text { preservado durante a ampliação da } \\
\text { área da igreja. No afloramento é } \\
\text { possível observar também a } \\
\text { ocorrência de bandas de gnaisse de } \\
\text { granulação mais fina (Figura } 6 \mathrm{E}), \\
\text { com presença de enclaves. }\end{array}$ & $\begin{array}{l}\text { - Afloramento de gnaisse } \\
\text { granítico com } \\
\text { bandamentos de } \\
\text { granulação mais fina. }\end{array}$ \\
\hline $\begin{array}{l}\text { Veios dobrados } \\
\text { da Trilha do } \\
\text { Jequitibá }\end{array}$ & $\begin{array}{c}\text { Sede do PESM - } \\
\text { Núcleo } \\
\text { Caraguatatuba, } \\
\text { Rodovia dos Tamoios, } \\
\text { seguindo pela Trilha } \\
\text { Jequitibá. }\end{array}$ & $\begin{array}{l}\text { Complexo granítico } \\
\text { Pico do Papagaio. }\end{array}$ & $\begin{array}{l}\text { Presença de rio com queda d'água } \\
\text { suave; Afloramento de gnaisse com } \\
\text { bandamentos e veios dobrados } \\
\text { (Figura 6F); Presença de veios } \\
\text { pegmatíticos cortando o } \\
\text { afloramento de forma discordante; } \\
\text { Grande quantidade de muscovita. }\end{array}$ & $\begin{array}{l}\text { - Dobramentos; } \\
\text { - Alta presença de } \\
\text { muscovita; } \\
\text { - Veios pegmatíticos. }\end{array}$ \\
\hline $\begin{array}{l}\text { Granitos da } \\
\text { Praia da } \\
\text { Mococa }\end{array}$ & $\begin{array}{l}\text { Rod. Dr. Manoel } \\
\text { Hipólito do Rêgo, } \\
\text { Praia da Mococa, } \\
\text { seguir pela praia } \\
\text { sentido sul. }\end{array}$ & $\begin{array}{l}\text { Depósitos } \\
\text { litorâneos. }\end{array}$ & $\begin{array}{c}\text { Afloramento de granito gnássico } \\
\text { com porções de granulação grossa } \\
\text { e mais fina; Intrusões de diques } \\
\text { máficos e veios com megacristais } \\
\text { de quartzo. }\end{array}$ & $\begin{array}{l}\text { - Afloramento de granito } \\
\text { gnáissico adentrando ao } \\
\text { mar (Figura 6G); } \\
\text { - Diques máficos; } \\
\text { - Veios com megacristais } \\
\text { de quartzo. }\end{array}$ \\
\hline
\end{tabular}

\subsubsection{Município de Ubatuba}

Em Ubatuba o litotipo predominante é o charnockito, que aflora somente neste segmento do litoral norte de São Paulo, além de outras rochas como granitos gnáissicos, leucogranitos e migmatitos (Perrotta et al., 2005). O charnockito, conhecido comercialmente como Granito Verde Ubatuba, é descrito por Neumann (1993) como uma rocha equigranular a porfirítica, de granulometria com matriz média a grossa, geralmente pouco foliada, apresentando coloração típica em tons de verde escuro. 
No município foram selecionados 6 sítios da geodiversidade (Tabela 9), aos quais 5 demonstram processos geológicos e geomorfológicos recentes, sendo o sítio "Charnockito da Cachoeira do Prumirim" relacionado com eventos geológicos mais antigos da fase de amalgamação do Supercontinente Gondwana.
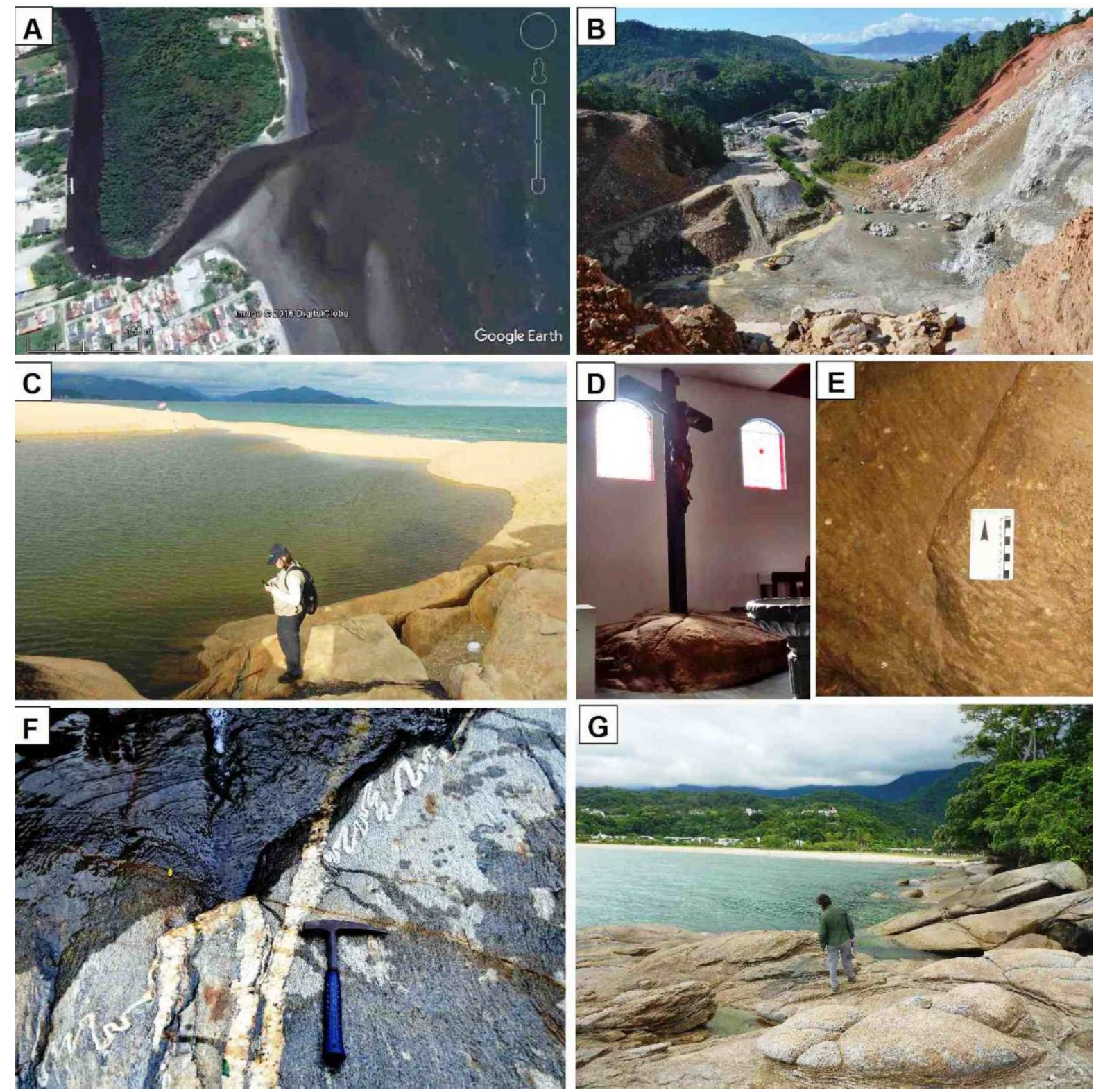

Figura 6 Sítios da geodiversidade no município de Caraguatatuba. A) Foz do Rio Juqueriquerê, Fonte: Google Earth; B) Pedreira Massaguaçu; C) Lagoa Azul; D) Gnaisse da Paróquia Santo Antônio; E) detalhe do Gnaisse da Paróquia de Santo Antônio, com intrusões de granulação mais fina; F) Veios Dobrados da Trilha Jequitibá; G) Granitos da Mococa. 
Tabela 9 Descrição dos sítios da geodiversidade inventariados no município de Ubatuba.

\begin{tabular}{|c|c|c|c|c|}
\hline $\begin{array}{c}\text { Sítio da } \\
\text { Geodiversidade }\end{array}$ & Acesso & $\begin{array}{l}\text { Unidade } \\
\text { litoestratigráfica } \\
\text { (Perrotta et al. } \\
\text { 2005) }\end{array}$ & Descrição geológica & $\begin{array}{l}\text { Feições da Geodiversidade } \\
\text { com potencial para uso } \\
\text { educacional e/ou turístico }\end{array}$ \\
\hline $\begin{array}{l}\text { Charnockito da } \\
\text { Cachoeira do } \\
\text { Prumirim }\end{array}$ & $\begin{array}{l}\text { Km } 24 \text { da BR-101, à } \\
\text { direita no sentido } \\
\text { norte. }\end{array}$ & $\begin{array}{l}\text { Charnockito } \\
\text { Ubatuba. }\end{array}$ & $\begin{array}{l}\text { Afloramento de charnockito de } \\
\text { coloração rosada alterada pelo } \\
\text { intemperismo (Figura 7A), } \\
\text { presença de poços, queda d'água } \\
\text { sobre fratura na rocha. }\end{array}$ & $\begin{array}{l}\text { - Queda d’água; } \\
\text { - Intemperismo no } \\
\text { charnockito; } \\
\text { - Fraturas na rocha. }\end{array}$ \\
\hline $\begin{array}{l}\text { Praia da } \\
\text { Fazenda }\end{array}$ & $\begin{array}{l}\text { Km } 11 \text { da BR-101, à } \\
\text { direita no sentido } \\
\text { norte. }\end{array}$ & $\begin{array}{c}\text { Granitos } \\
\text { calcialcalinos Tipo } \\
\text { I: Parati. }\end{array}$ & $\begin{array}{c}\text { Depósito litorâneo; } \\
\text { Costões graníticos; } \\
\text { Foz no encontro de dois rios com } \\
\text { o mar. }\end{array}$ & $\begin{array}{c}\text { - Encontro dos rios Fazenda e } \\
\text { Picinguaba; } \\
\text { - Foz do rio; } \\
\text { - Sedimentação fluvial e } \\
\text { assoreamento do rio Fazenda; } \\
\text {-Esporão composto de areia. } \\
\text { - Blocos formados por fraturas } \\
\text { tectônicas; } \\
\text { - Presença de diques; } \\
\text { - Marcas onduladas na areia } \\
\text { (Figura7B); } \\
\text { - Deposição de minerais } \\
\text { pesados. }\end{array}$ \\
\hline $\begin{array}{l}\text { Mirante do } \\
\text { Engenho }\end{array}$ & $\begin{array}{l}\text { Ilha Anchieta, } \\
\text { localizado na Trilha do } \\
\text { Engenho. }\end{array}$ & $\begin{array}{l}\text { Granitos foliados } \\
\text { calcialcalinos Tipo } \\
\text { I: Ilha Anchieta. }\end{array}$ & $\begin{array}{c}\text { Ponto de observação localizado à } \\
\text { margem do costão da Praia do } \\
\text { Engenho. }\end{array}$ & $\begin{array}{l}\text { Mirante com vista para praias } \\
\text { da ilha Anchieta e Serra do Mar } \\
\text { (Figura 7C). }\end{array}$ \\
\hline $\begin{array}{l}\text { Esporão do } \\
\text { Puruba }\end{array}$ & $\begin{array}{l}\text { BR-101, sentido norte } \\
\text { virar à direita após a } \\
\text { ponte do rio Puruba. }\end{array}$ & $\begin{array}{c}\text { Charnockito } \\
\text { Ubatuba. }\end{array}$ & $\begin{array}{l}\text { Depósito litorâneo; } \\
\text { Foz do rio Puruba (Figura 7D); } \\
\text { Deposição de minerais pesados; } \\
\text { Formação da "barra" no rio. }\end{array}$ & $\begin{array}{l}\text { - Esporão complexo com } \\
\text { aproximadamente } 1 \mathrm{~km} \text { de } \\
\text { extensão (Figura 7E); } \\
\text { - Deposição de minerais } \\
\text { pesados intercalados. }\end{array}$ \\
\hline Praia da Lagoa & $\begin{array}{l}\text { BR-101, sentido norte, } \\
\text { após a polícia } \\
\text { rodoviária entrar à } \\
\text { direita na rua Oito. }\end{array}$ & $\begin{array}{l}\text { Unidade Granito } \\
\text { Gnáissica } \\
\text { Migmatítica. }\end{array}$ & $\begin{array}{l}\text { Depósito litorâneo; } \\
\text { Lagoa disposta paralela e lateral } \\
\text { à linha de costa (Figura 7F); } \\
\text { Presença de xenólitos. }\end{array}$ & $\begin{array}{l}\text { - Disposição geográfica da } \\
\text { lagoa. } \\
\text { - Presença das Ruínas da } \\
\text { Lagoa. }\end{array}$ \\
\hline $\begin{array}{l}\text { Praia das } \\
\text { Conchas }\end{array}$ & $\begin{array}{l}\text { Na BR-101 pegar a } \\
\text { primeira entrada para } \\
\text { Tabatinga, seguir em } \\
\text { estrada de terra por } \\
1,5 \mathrm{~km} \text {, depois uma } \\
\text { pequena trilha } \\
\text { passando por } \\
\text { propriedade } \\
\text { particular. }\end{array}$ & $\begin{array}{c}\text { Granitos } \\
\text { calcialcalinos Tipo } \\
\text { I: Parati. }\end{array}$ & $\begin{array}{l}\text { Afloramento de charnockito de } \\
\text { coloração rosada pelo } \\
\text { intemperismo. }\end{array}$ & $\begin{array}{l}\text { - Afloramento de charnockito } \\
\text { de coloração rosada e } \\
\text { disposição de blocos (Figura } \\
\text { 9G); } \\
\text { - Vista para a Ilha; } \\
\text { - Presença de conchas. }\end{array}$ \\
\hline
\end{tabular}

\subsection{Avaliação quantitativa}

Através da avaliação quantitativa dos sítios, foram obtidos os valores do potencial de uso educativo e turístico, situando-se entre 205 a 325 e 210 a 315 , respectivamente (Tabela 10). Alguns parâmetros da avaliação apresentaram valores iguais para todos os sítios da geodiversidade, como é o caso do "Logística" (C5), "Associação com outros valores" (C7), "Nível ecônomico" (C14) e "Proximidade a zonas recreativas" $(\mathrm{C} 15)$. 

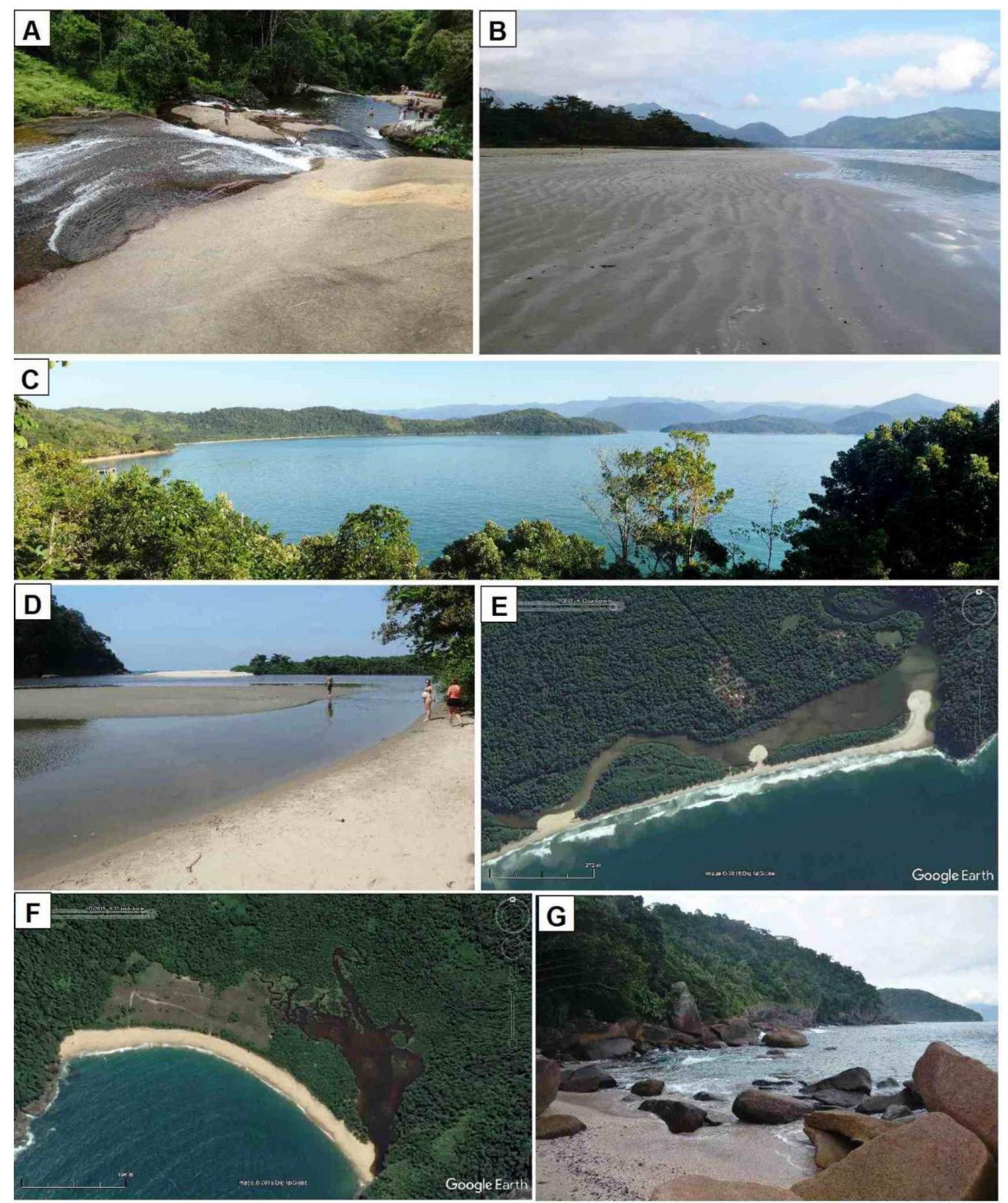

Figura 7 Sítios da Geodiversidade localizados no município de Ubatuba. A) Charnockito da Cachoeira do Prumirim; B) marcas onduladas na areia da Praia da Fazenda; C) vista a partir do Mirante do Engenho; D) Esporão do Puruba; E) imagem de satélite do esporão do puruba, mostrando a extensão do esporão e suas 3 barras para dentro do continente (Fonte: Google Earth); F) imagem de satélite da Praia da Lagoa, onde pode ser vista a localização da lagoa próxima a praia (Fonte: Google Earth); G) Praia das Conchas.

Os valores obtidos na quantificação do risco de degradação (Tabela 11) variaram de 30 a 360. Tais valores são classificados em: Baixo ( $\leq 200)$; Médio (201 - 300); e Alto (301 - 400) (Brilha, 2016), e são avaliadas tanto em relação às ameaças antrópicas 
quanto às naturais, ou seja, a vulnerabilidade e a suscetibilidade do sítio, respectivamente.

Tabela 10 Quantificação do potencial de uso educacional $(\mathrm{Pe})$ e turístico $(\mathrm{Pt})$ dos Sítios da Geodiversidade do litoral norte de São Paulo, através da plataforma GEOSSIT.

\begin{tabular}{|c|c|c|c|c|c|c|c|c|c|c|c|c|c|c|c|c|c|}
\hline Sítios da Geodiversidade & C1 & C2 & C3 & C4 & C5 & $\mathrm{C6}$ & C7 & $\mathrm{C8}$ & C9 & C10 & C11 & C12 & C13 & C14 & C15 & $\mathrm{Pe}$ & Pt \\
\hline $\begin{array}{c}\text { Dique da Cachoeira do } \\
\text { Cambury }\end{array}$ & 4 & 0 & 2 & 1 & 4 & 2 & 4 & 2 & 2 & 4 & 1 & 2 & 2 & 1 & 4 & 210 & 225 \\
\hline Praia Brava & 3 & 0 & 2 & 2 & 4 & 2 & 4 & 1 & 1 & 4 & 2 & 3 & 3 & 1 & 4 & 230 & 210 \\
\hline Tômbolo das Calhetas & 4 & 3 & 4 & 4 & 4 & 2 & 4 & 2 & 1 & 4 & 3 & 3 & 4 & 1 & 4 & 325 & 305 \\
\hline Mirante da Barra do Una & 3 & 4 & 4 & 2 & 4 & 2 & 4 & 2 & 1 & 4 & 3 & 2 & 4 & 1 & 4 & 295 & 285 \\
\hline $\begin{array}{c}\text { Intrusões Máficas de } \\
\text { Barequeçaba }\end{array}$ & 3 & 3 & 4 & 2 & 4 & 2 & 4 & 1 & 2 & 4 & 1 & 3 & 2 & 1 & 4 & 255 & 250 \\
\hline Praia do Oscar & 4 & 3 & 4 & 2 & 4 & 1 & 4 & 2 & 2 & 4 & 1 & 3 & 2 & 1 & 4 & 265 & 270 \\
\hline Trilha da Água Branca & 4 & 1 & 2 & 2 & 4 & 1 & 4 & 2 & 2 & 4 & 1 & 3 & 2 & 1 & 4 & 235 & 240 \\
\hline Diques da Siriúba & 4 & 3 & 4 & 2 & 4 & 1 & 4 & 2 & 1 & 4 & 1 & 2 & 2 & 1 & 4 & 250 & 260 \\
\hline Cachoeira da Toca & 4 & 0 & 2 & 2 & 4 & 1 & 4 & 2 & 1 & 4 & 1 & 3 & 2 & 1 & 4 & 220 & 220 \\
\hline Lago Dourado & 4 & 0 & 2 & 1 & 4 & 1 & 4 & 2 & 2 & 4 & 2 & 2 & 4 & 1 & 4 & 225 & 240 \\
\hline Cachoeira da Laje & 4 & 0 & 2 & 1 & 4 & 1 & 4 & 2 & 2 & 4 & 1 & 2 & 2 & 1 & 4 & 205 & 220 \\
\hline Pico de São Sebastião & 4 & 0 & 1 & 2 & 4 & 1 & 4 & 2 & 4 & 4 & 3 & 2 & 2 & 1 & 4 & 260 & 245 \\
\hline Praia dos Castelhanos & 4 & 0 & 4 & 2 & 4 & 1 & 4 & 2 & 1 & 4 & 3 & 2 & 4 & 1 & 4 & 260 & 250 \\
\hline Foz do rio Juqueriquerê & 4 & 4 & 4 & 2 & 4 & 2 & 4 & 1 & 1 & 4 & 3 & 2 & 4 & 1 & 4 & 300 & 280 \\
\hline Pedreira Massaguaçu & 4 & 4 & 2 & 2 & 4 & 2 & 4 & 0 & 1 & 3 & 1 & 2 & 1 & 1 & 4 & 235 & 220 \\
\hline Lagoa Azul & 4 & 4 & 4 & 2 & 4 & 2 & 4 & 2 & 1 & 4 & 3 & 2 & 4 & 1 & 4 & 305 & 295 \\
\hline $\begin{array}{c}\text { Gnaisse da Paróquia Santo } \\
\text { Antônio }\end{array}$ & 1 & 4 & 3 & 4 & 4 & 2 & 4 & 2 & 2 & 4 & 1 & 2 & 2 & 1 & 4 & 255 & 270 \\
\hline $\begin{array}{c}\text { Veios dobrados da Trilha do } \\
\text { Jequitibá }\end{array}$ & 4 & 4 & 2 & 3 & 4 & 2 & 4 & 2 & 2 & 4 & 1 & 2 & 2 & 1 & 4 & 270 & 285 \\
\hline $\begin{array}{c}\text { Granitos da Praia da } \\
\text { Mococa }\end{array}$ & 4 & 4 & 4 & 2 & 4 & 2 & 4 & 1 & 2 & 4 & 1 & 2 & 2 & 1 & 4 & 265 & 270 \\
\hline $\begin{array}{c}\text { Charnockito da Cachoeira } \\
\text { do Prumurim }\end{array}$ & 4 & 4 & 4 & 3 & 4 & 2 & 4 & 2 & 4 & 4 & 1 & 2 & 2 & 1 & 4 & 290 & 315 \\
\hline Praia da Fazenda & 3 & 2 & 4 & 2 & 4 & 2 & 4 & 2 & 2 & 4 & 1 & 3 & 2 & 1 & 4 & 250 & 255 \\
\hline Mirante do Engenho & 4 & 0 & 2 & 3 & 4 & 2 & 4 & 2 & 2 & 4 & 2 & 2 & 4 & 1 & 4 & 250 & 265 \\
\hline Esporão do Puruba & 3 & 2 & 4 & 2 & 4 & 2 & 4 & 2 & 1 & 4 & 2 & 3 & 4 & 1 & 4 & 265 & 265 \\
\hline Praia da Lagoa & 4 & 1 & 4 & 2 & 4 & 2 & 4 & 2 & 2 & 4 & 3 & 2 & 4 & 1 & 4 & 280 & 275 \\
\hline Praia das Conchas & 4 & 0 & 2 & 2 & 4 & 2 & 4 & 1 & 2 & 4 & 1 & 2 & 3 & 1 & 4 & 215 & 230 \\
\hline
\end{tabular}

Tabela 11 Quantificação do Risco de Degradação dos Sítios da Geodiversidade do Litoral Norte de São Paulo, através da Plataforma GEOSSIT.

\begin{tabular}{|c|c|c|c|c|c|c|}
\hline Sítios da Geodiversidade & B1 & B2 & B3 & B4 & B5 & $\begin{array}{l}\text { Valor do Risco de } \\
\text { Degradação }\end{array}$ \\
\hline Dique da Cachoeira do Cambury & 0 & 0 & 1 & 0 & 2 & 40 \\
\hline Praia Brava & 2 & 0 & 2 & 0 & 2 & 130 \\
\hline Tômbolo das Calhetas & 1 & 4 & 1 & 3 & 2 & 200 \\
\hline Mirante da Barra do Una & 1 & 4 & 4 & 4 & 2 & 275 \\
\hline Intrusões Máficas de Barequeçaba & 3 & 3 & 2 & 3 & 2 & 270 \\
\hline Praia do Oscar & 1 & 4 & 4 & 3 & 1 & 250 \\
\hline Trilha da Água Branca & 0 & 0 & 1 & 1 & 1 & 45 \\
\hline Diques da Siriúba & 1 & 4 & 2 & 3 & 1 & 210 \\
\hline Cachoeira da Toca & 0 & 0 & 2 & 0 & 1 & 50 \\
\hline Lago Dourado & 1 & 0 & 2 & 0 & 1 & 85 \\
\hline Cachoeira da Laje & 0 & 0 & 2 & 0 & 1 & 50 \\
\hline Pico de São Sebastião & 0 & 0 & 1 & 0 & 1 & 30 \\
\hline Praia dos Castelhanos & 0 & 0 & 2 & 2 & 1 & 80 \\
\hline Foz do rio Juqueriquerê & 0 & 1 & 2 & 2 & 2 & 110 \\
\hline Pedreira Massaguaçu & 0 & 0 & 0 & 4 & 2 & 80 \\
\hline Lagoa Azul & 1 & 2 & 2 & 2 & 2 & 165 \\
\hline Gnaisse da Paróquia Santo Antônio & 1 & 4 & 2 & 4 & 2 & 235 \\
\hline Veios dobrados da Trilha do Jequitibá & 0 & 0 & 1 & 1 & 2 & 55 \\
\hline Granitos da Praia da Mococa & 1 & 3 & 2 & 3 & 2 & 200 \\
\hline Charnockito da Cachoeira do Prumurim & 0 & 4 & 2 & 4 & 2 & 200 \\
\hline
\end{tabular}




\begin{tabular}{cccccccc}
\hline Praia da Fazenda & 1 & 0 & 2 & 2 & 2 & 125 \\
\hline Mirante do Engenho & 0 & 0 & 1 & 0 & 2 & 40 \\
\hline Esporão do Puruba & 2 & 0 & 2 & 2 & 2 & 160 \\
\hline Praia da Lagoa & 0 & 1 & 2 & 1 & 2 & 95 \\
\hline Praia das Conchas & 0 & 1 & 2 & 1 & 2 & 95 \\
\hline
\end{tabular}

\section{Discussão}

\subsection{Discussão dos resultados}

A partir dos dados adquiridos com o inventário e a análise quantitativa foi possível estabelecer valores numéricos aos sítios da geodiversidade e classificá-los de acordo com o potencial de uso educativo e/ou turístico com valores altos $(\leq 300)$ e muito altos (> 301). Neste caso, os sítios da geodiversidade que obtiveram valores muito altos foram: Tômbolo das Calhetas, com valores muito altos em potencial educativo e turístico; Lagoa Azul, com valor muito alto em potencial educativo; e Charnockito da Cachoeira do Prumirim, com valor muito alto em potencial turístico. Os valores adquiridos com a quantificação do potencial para o uso educacional e para o uso turístico não apresentaram grande diferença entre eles em cada sítio pontuado, obtendo cada sítio valores muito próximos entre os dois tipos de uso, como pode ser observado na Figura 8.

A partir da análise quantitativa pode-se observar que alguns parâmetros utilizados para valorar os sítios apresentaram o mesmo valor para todos os sítios avaliados na região, como em: "Logística" (C5), "Associação com outros valores" (C7) e "Proximidade a zonas recreativas" (C15) pontuados com o valor máximo (4 pontos) para todos os sítios. Isso ocorre devido ao fato da área de estudo estar localizada em uma região litorânea muito turística, apresentando grande diversidade cultural com a presença de comunidades tradicionais (Figura 9A e B) e restaurantes especializados na gastronomia local (Figura 9C). O Parque Estadual da Serra do Mar, Parque Estadual da Ilha Anchieta e o Parque Estadual da Ilhabela, com suas atrações turísticas que incluem trilhas e cachoeiras (Figura 9D), e a paisagem natural constituída por praias e serras, compõem uma beleza cênica atraente para turistas de todo o mundo (Figura 9E), o que demanda grande disponibilidade de serviços como hotéis, hostels e pousadas, agências de turismo e restaurantes diversos. Além disso, a região dispõe de alguns museus (Figura 9F) e centros de interpretação ambiental para lazer, como o Aquário de Ubatuba e o Projeto Tamar, abertos à visitação. 


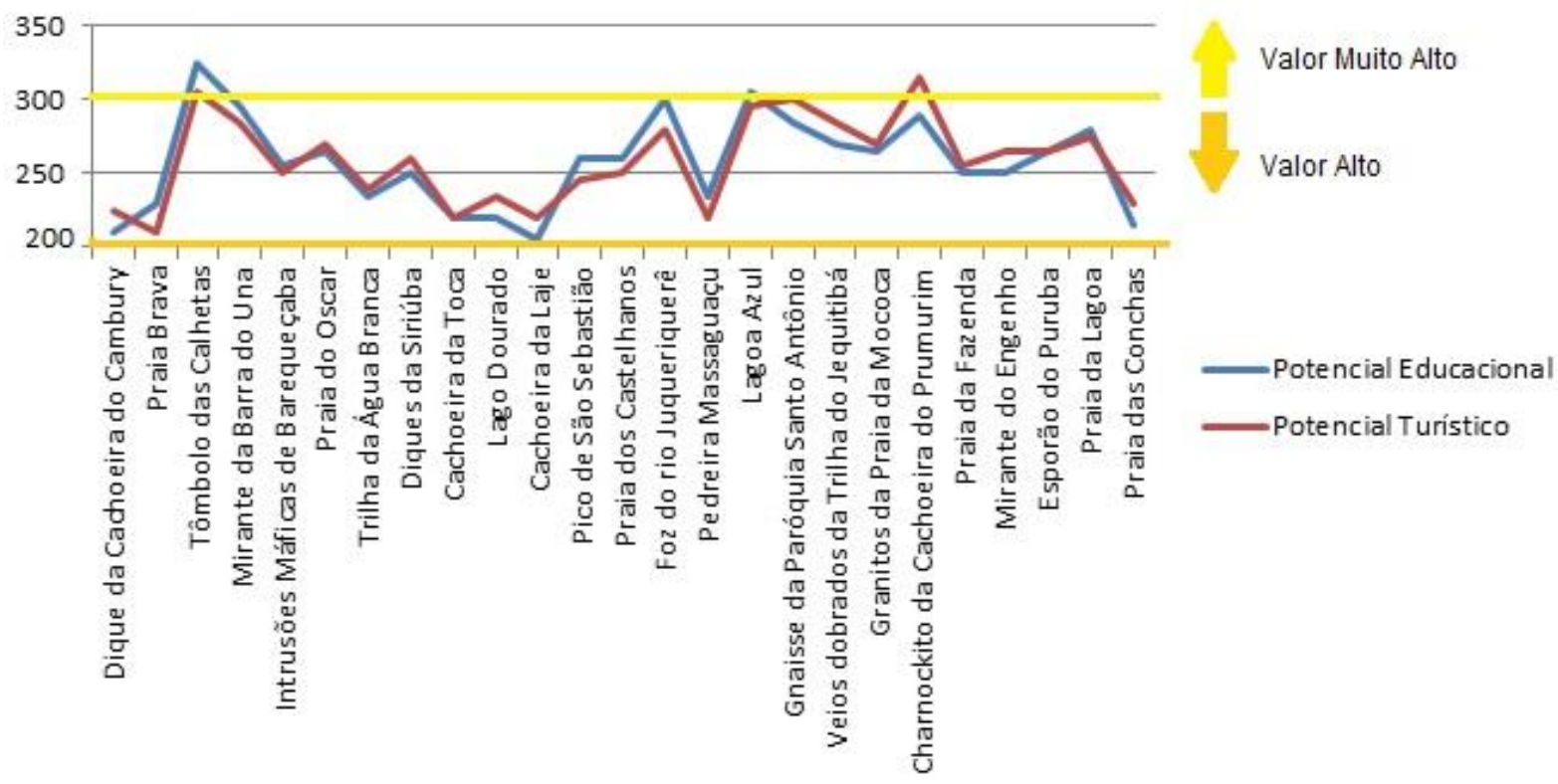

Figura 8 Gráfico de classificação dos valores da quantificação do potencial educacional e turístico dos sítios da geodiversidade.

No parâmetro "Vulnerabilidade" (C1) os sítios obtiveram pontuações altas (entre 3 e 4 pontos) por apresentarem pouca ou nenhuma possibilidade de deterioração dos elementos geológicos por atividades antrópicas. Considerando que o risco de deterioração superficial, como pixações, pinturas e riscos, é geral para todos os sítios, foi considerada a possibilidade de deterioração mais intensa, que resulte por destruir uma parte ou até mesmo todo o sítio através de intervenções antrópicas decorrente, principalmente, de construções civis devido à alta especulação imobiliária na região.

O parâmetro "Nível econômico" (C14) foi valorado com 1 ponto para todos os sítios da região. Isso ocorre porque os munícipios onde estão localizados estes sítios possuem o IDH inferior ao que se verifica no estado de São Paulo, embora sejam valores muito próximos. A baixa pontuação neste parâmetro causa diminuição no valor final do potencial para uso turístico.

Os sítios que obtiveram baixos valores em risco de degradação apresentam maior estabilidade dos elementos geológicos, podendo receber visitação sem grandes impactos ambientais. Os sítios que obtiveram valor médio são: Mirante da Barra do Una; Intrusões Máficas de Barequeçaba; Praia do Oscar e Diques da Siriúba.

O Mirante Barra do Una obteve este valor por estar localizado próximo à área com potencial para causar degradação, pois há uma estrada localizada a $3 \mathrm{~m}$ de distância do sítio, além da presença de um estacionamento próximo ao local e a falta de proteção 
e de controle de acesso fazem com que o valor aumente, sendo necessária a implantação de uma política de proteção legal deste sítio da geodiversidade para que o risco de degradação seja minimizado.

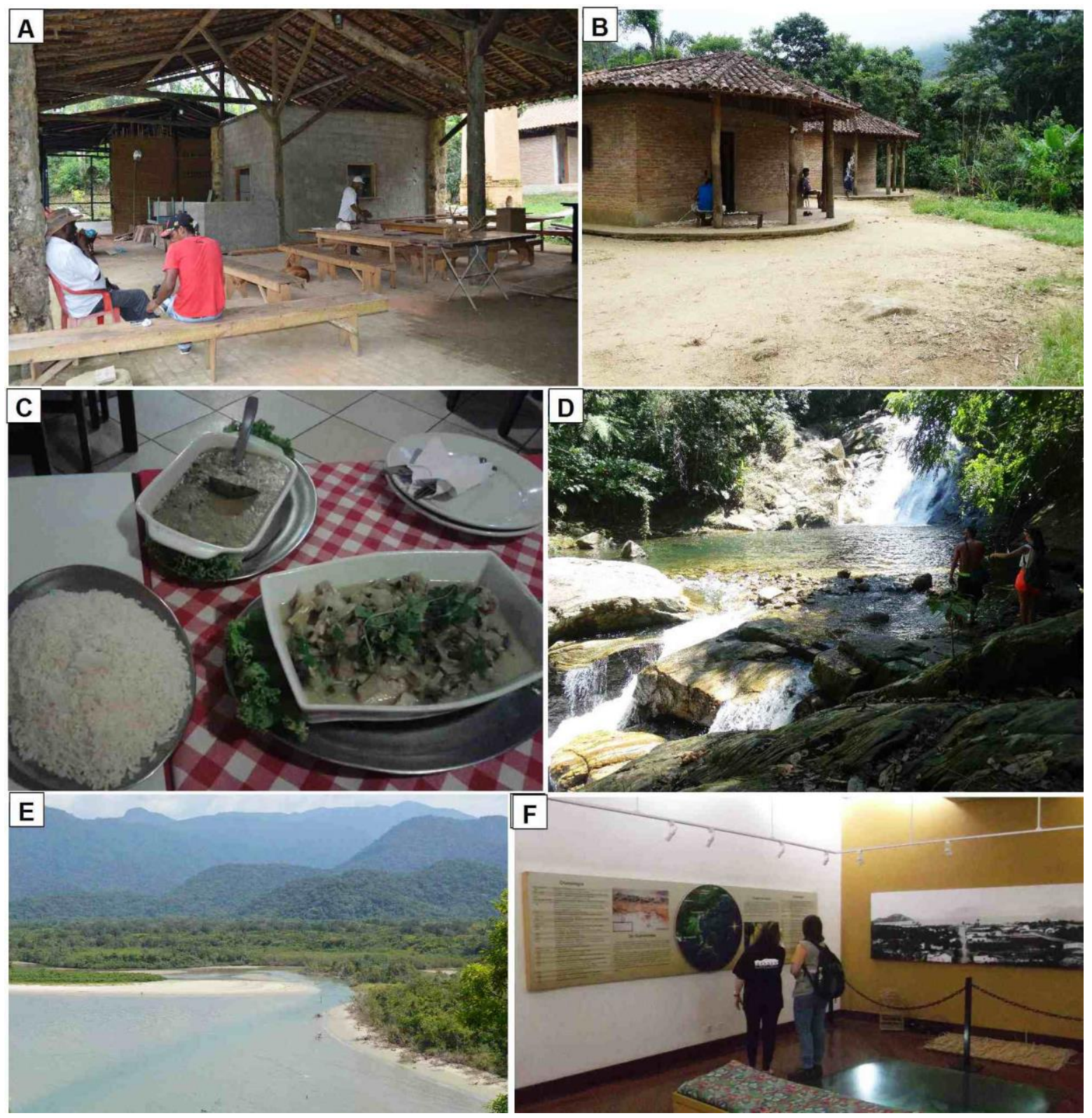

Figura 9 A) Casa de Farinha localizada em uma comunidade quilombola em Picinguaba, Ubatuba; B) Aldeia Indígena Boa Vista, localizada no bairro do Prumirim em Ubatuba; C) Prato típico da gastronomia caiçara, chamado "Peixe Azul-Marinho"; D) Cachoeira da Trilha do Riberão do Itu, Parque Estadual da Serra do Mar em São Sebastião; E) Praia da Fazenda, Ubatuba; F) Museu de Arte e Cultura de Caraguatatuba.

O sítio Intrusões Máficas de Barequeçaba apresentou este valor pela alta possibilidade de deterioração dos elementos geológicos, por estar localizado ao lado de uma construção e perto de estrada asfaltada. A Praia do Oscar e os Diques de Siriúba 
estão localizados a menos de $100 \mathrm{~m}$ de uma estrada asfaltada e não possuem controle de acesso.

\subsection{Propostas para a utilização dos sítios da geodiversidade}

A partir dos resultados obtidos neste trabalho foi possível sugerir propostas para a utilização apropriada desses sítios. Em Guimarães (2016), as medidas de intervenção foram divididas em: i) medidas estruturais: intervenção física no geossítio, como obras de infraestrutura destinada a todos os públicos; e ii) medidas não estruturais, direcionada a públicos específicos, como trabalhos de divulgação e conscientização da importância da geodiversidade.

Alguns exemplos destas medidas podem ser visualizados na Figura 10, onde medidas estruturais como grade de segurança em mirante (Figura 10A), instalação de painéis interpretativos (Figura 10B) e estruturas de segurança ao redor do sítio (Figura 10C), objetivam tanto para proteger o sítio, como para garantir a segurança dos visitantes.

Como exemplos de medidas não estruturais têm-se os cursos sobre patrimônio geológico e geociências, que podem ser dados para pesquisadores e público geral (Figura 10D), ou para públicos específicos como monitores ambientais (Figura 10E), professores, guias turísticos, entre outros. Atividades lúdicas que abordem a temática também são bem-vindas, como jogos, teatros (Figura 10F), multimídia, concursos de fotografia e de desenhos.

Para propor medidas estruturais e não estruturais neste trabalho, foram utilizados os dados da quantificação. Sendo assim, os sítios da geodiversidade que obtiveram valores de potencial de uso (educativo e turístico) muito alto e risco de degradação baixos, como Tômbolo de Calhetas, Lagoa Azul e Charnockito da Cachoeira do Prumirim, são fortes concorrentes para investimentos iniciais em divulgação geocientífica. Esses sítios já são locais conhecidos pelo público local como pontos turísticos, com fluxo constante de visitantes.

Nos sítios da geodiversidade que já apresentam divulgação turística local, indicam-se medidas não estruturais, como inclusão de informações geológicas nos sites de turismo e folders com informações geológicas disponíveis em agências de turismo, hoteis e comércio local. 

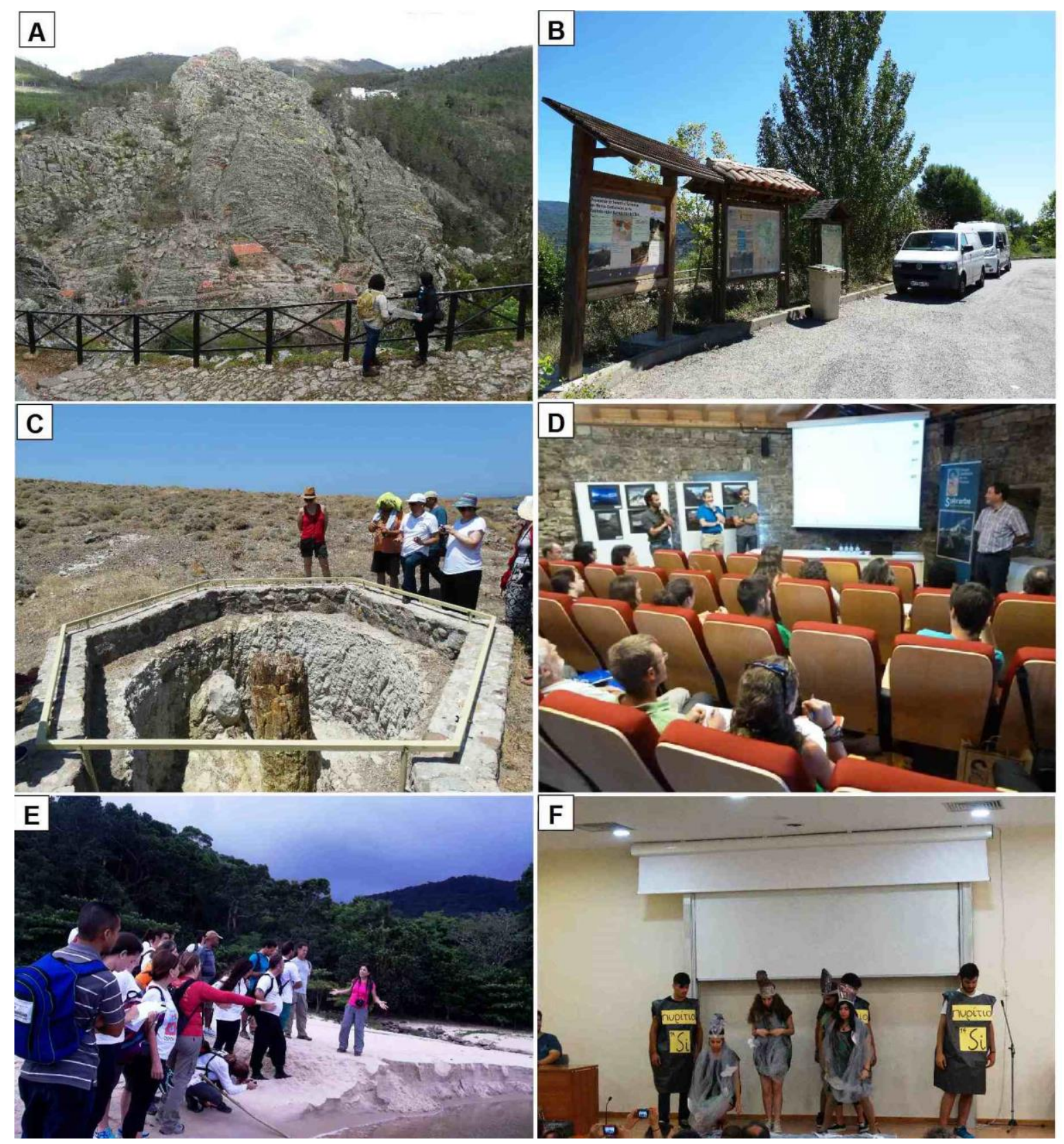

Figura 10 Exemplos de medidas de intervenções nos sítios. A) Grade de segurança para a visualização no mirante, Geoparque Naturtejo em Portugal; B) Painéis interpretativos na estrada, Geoparque de Sobrarbe, Espanha; C) Estrutura de proteção em torno do geossítio, Geoparque de Lesvos, Grécia; D) Curso de patrimônio geológico e geoturismo no Geoparque Sobrarbe, Espanha; E) Curso de geociências para monitores ambientais em São Sebastião, São Paulo; F) Peça teatral infantil sobre a fossilização dos troncos encontrados no Geoparque de Lesvos, Grécia.

Sítios considerados com alto potencial educativo devem receber medidas não estruturais, representadas nos cursos de capacitação em geociências para professores locais, além de materiais didáticos que abordem as questões relativas à geodiversidade para serem usados em aulas de campo pelos alunos. As medidas estruturais são muito importantes para este tipo de sítio da geodiversidade, visando garantir a segurança na 
acessibilidade, como escadas, corrimãos, cordas, redes de segurança, entre outros, para suportar um número razoável de alunos em excursões didáticas e aulas de campo com maior segurança.

A seguir, serão apresentadas algumas propostas de medidas estruturais e de atividades educativas e turísticas para cada município (Tabelas 12, 13, 14 e 15). Atualmente, alguns sítios não apresentam necessidade de medidas estruturais.

Tabela 12 Propostas de medidas estruturais e de atividades educativas e turísticas nos sítios da geodiversidade em São Sebastião.

\begin{tabular}{|c|c|c|}
\hline $\begin{array}{l}\text { Sítio da } \\
\text { Geodiversidade }\end{array}$ & Propostas de medidas estruturais & Propostas de atividades educativas e turísticas \\
\hline $\begin{array}{l}\text { Mirante da } \\
\text { Barra do Una }\end{array}$ & $\begin{array}{c}\text { - Painel interpretativo descrevendo a } \\
\text { formação da paisagem composta pela Serra } \\
\text { do Mar ao fundo e a barra deposicional do } \\
\text { Rio Una. }\end{array}$ & $\begin{array}{l}\text {-Explicar a geomorfologia da região, visto que do mirante é } \\
\text { possível abordar as ilhas dos municípios e as escarpas da } \\
\text { Serra do Mar; } \\
\text { - Visitar a sede do Núcleo São Sebastião do Parque Estadual } \\
\text { da Serra do Mar; } \\
\text { - Abordar a dinâmica costeira e o encontro do rio com o mar } \\
\text { (foz). }\end{array}$ \\
\hline $\begin{array}{l}\text { Dique da } \\
\text { Cachoeira do } \\
\text { Cambury }\end{array}$ & - & $\begin{array}{l}\text { - Trilha do Sertão do Cambury, até a terceira queda; } \\
\text { - Explicar o processo de intemperismo no dique; } \\
\text { - Abordar a evolução do Gondwana com base nos dois } \\
\text { litotipos de fases diferentes - rocha e dique. }\end{array}$ \\
\hline Praia Brava & $\begin{array}{l}\text { - Painel interpretativo descrevendo o } \\
\text { processo de transporte e deposição das } \\
\text { rochas no final da trilha. }\end{array}$ & $\begin{array}{l}\text { - Trilha da Praia Brava com parada no Geossítio Mirante da } \\
\text { Praia Brava, onde é possível abordar a geomorfologia da Serra } \\
\text { do Mar, ocupação irregular e deslizamentos. }\end{array}$ \\
\hline $\begin{array}{l}\text { Tômbolo das } \\
\text { Calhetas }\end{array}$ & $\begin{array}{l}\text { - Painel interpretativo descrevendo como } \\
\text { ocorre a formação do tômbolo. }\end{array}$ & $\begin{array}{l}\text { - Subida ao mirante do ilhote para observação das escarpas } \\
\text { da Serra do Mar e das ilhas e do município de São Sebastião, } \\
\text { incluindo Alcatrazes; } \\
\text { - Atividades no costão para observação das rochas e suas } \\
\text { feições; } \\
\text { - Atividade recreativa nas piscinas naturais rodeadas por } \\
\text { blocos de rochas, e explicar o processo de erosão que gerou } \\
\text { esses blocos. }\end{array}$ \\
\hline $\begin{array}{l}\text { Intrusões } \\
\text { Máficas de } \\
\text { Barequeçaba }\end{array}$ & - & $\begin{array}{l}\text { - Explicar a diferença entre sill e dique; } \\
\text {-Abordar os eventos tectônicos que ocorreram na região e } \\
\text { explicar como se dá as intrusões nas rochas. }\end{array}$ \\
\hline
\end{tabular}

Tabela 13 Propostas de medidas estruturais e de atividades educativas e turísticas nos sítios da geodiversidade em Ilhabela.

\begin{tabular}{|c|c|l|}
\hline $\begin{array}{c}\text { Sítio da } \\
\text { Geodiversidade }\end{array}$ & Propostas de medidas estruturais & Propostas de atividades educativas e turísticas \\
\hline Praia do Oscar & $\begin{array}{c}\text { - Painel interpretativo sobre a formação } \\
\text { dos diques visualizados nos costões. }\end{array}$ & $\begin{array}{l}\text { - Explicar como se formam as fraturas e a formação de } \\
\text { diques, relacionando essas feições à fragmentação do } \\
\text { supercontinente Gondwana e abertura do Atlântico Sul. }\end{array}$ \\
\hline $\begin{array}{c}\text { Trilha da Água } \\
\text { Branca }\end{array}$ & - Folheto interpretativo para utilizar no \\
percurso da trilha. & $\begin{array}{l}\text { - Associar a queda d'água com o processo de erosão } \\
\text { diferencial no dique do Poço da Escada; } \\
\text { - Explicar a formação de blocos a partir da presença de } \\
\text { fraturas; } \\
\text { - Observar a presença de matacões e blocos e relacioná-los } \\
\text { com o fluxo de energia do rio. }\end{array}$ \\
\hline
\end{tabular}




\begin{tabular}{|c|c|c|}
\hline $\begin{array}{l}\text { Diques da } \\
\text { Siriúba }\end{array}$ & $\begin{array}{l}\text { - Estruturas de segurança no costão (ex: } \\
\text { corrimão). }\end{array}$ & $\begin{array}{l}\text { - Explicar a formação de diques e relacioná-los com a } \\
\text { separação dos continentes; } \\
\text { - Abordar como ocorre o processo de erosão esferoidal; }\end{array}$ \\
\hline $\begin{array}{l}\text { Cachoeira da } \\
\text { Toca }\end{array}$ & - & $\begin{array}{l}\text { - Explicar a ação da água sobre os sedimentos transportados; } \\
\text { - Relacionar os sedimentos transportados com o ciclo das } \\
\text { rochas; } \\
\text { - Identificar a presença de diques e relacioná-los com a } \\
\text { fragmentação do supercontinente Gondwana. }\end{array}$ \\
\hline Lago Dourado & - & $\begin{array}{l}\text { - Abordar a erosão das rochas e o transporte de sedimentos; } \\
\text { - Inferir a proveniência dos sedimentos depositados no fundo } \\
\text { do lago. }\end{array}$ \\
\hline $\begin{array}{l}\text { Cachoeira da } \\
\text { Laje }\end{array}$ & - & $\begin{array}{l}\text { - Explicar as zonas de fraqueza da rocha e como se formaram } \\
\text { as fraturas que originam a "escada natural" no afloramento. }\end{array}$ \\
\hline $\begin{array}{l}\text { Pico de São } \\
\text { Sebastião }\end{array}$ & $\begin{array}{l}\text { - Confecção e distribuição de folhetos } \\
\text { informativos sobre a paisagem } \\
\text { geomorfológica visualizada a partir do } \\
\text { mirante, e sobre a formação da Ilha de São } \\
\text { Sebastião. }\end{array}$ & $\begin{array}{l}\text { - Observação da paisagem geomorfológica visualizada a partir } \\
\text { do mirante. }\end{array}$ \\
\hline $\begin{array}{c}\text { Praia dos } \\
\text { Castelhanos }\end{array}$ & - & $\begin{array}{l}\text { - Passeio na Praia dos Castelhanos explicando como ocorre o } \\
\text { mecanismo de sedimentação e deposição dos sedimentos; } \\
\text { - Relacionar os minerais presentes no costão com os grãos de } \\
\text { areia na praia. }\end{array}$ \\
\hline
\end{tabular}

Tabela 14 Propostas de medidas estruturais e de atividades educativas e turísticas nos sítios da geodiversidade em Caraguatatuba.

\begin{tabular}{|c|c|c|}
\hline $\begin{array}{l}\text { Sítio da } \\
\text { Geodiversidade }\end{array}$ & Propostas de medidas estruturais & Propostas de atividades educativas e turísticas \\
\hline $\begin{array}{l}\text { Foz do Rio } \\
\text { Juqueriquerê }\end{array}$ & - & $\begin{array}{l}\text { - Recreação na foz do Rio Juqueriquerê com explicação do } \\
\text { mecanismo de transporte e deposição de sedimentos na foz; } \\
\text { - Observar feições geomorfológicas associadas à foz em delta. } \\
\text {. }\end{array}$ \\
\hline $\begin{array}{l}\text { Pedreira } \\
\text { Massaguaçu }\end{array}$ & - & $\begin{array}{l}\text { - Explicar como se dá o processo de mineração; } \\
\text { - Passeio na mineradora com explicação geológica da rocha } \\
\text { explorada e suas estruturas; } \\
\text { - Atividade sensorial com os indicadores cinemáticos. }\end{array}$ \\
\hline Lagoa Azul & $\begin{array}{l}\text { - Painel de divulgação descrevendo a } \\
\text { formação da barra arenosa e a dinâmica da } \\
\text { Lagoa. }\end{array}$ & $\begin{array}{l}\text { - Observar a dinâmica da barra arenosa relacionada ao fluxo } \\
\text { de água no rio; } \\
\text { - Observar o transporte e deposição de sedimentos; } \\
\text { - Passeio na Praia do Capricórnio com identificação de bermas } \\
\text { e explicação de praias de tombo; } \\
\text { - Banho de rio na foz/lagoa; } \\
\text { - Explicar a diferença granulométrica da areia da praia e da } \\
\text { areia da barra. }\end{array}$ \\
\hline $\begin{array}{l}\text { Veios dobrados } \\
\text { da Trilha do } \\
\text { Jequitibá }\end{array}$ & - & $\begin{array}{l}\text { - Caminhada pela Trilha Jequitibá com parada no ponto do } \\
\text { afloramento; } \\
\text { - Explicar o mecanismo de ambientes ductéis: veios dobrados. }\end{array}$ \\
\hline $\begin{array}{l}\text { Gnaisse da } \\
\text { Paróquia Santo } \\
\text { Antônio }\end{array}$ & $\begin{array}{l}\text { - Folhetos informativos com explicação dos } \\
\text { aspectos geológicos existentes dentro da } \\
\text { paróquia. }\end{array}$ & $\begin{array}{l}\text { - Geoturismo dentro da Paróquia, observando as rochas } \\
\text { ornamentais que compõem o patrimônio construído e o } \\
\text { afloramento de gnaisse e associá-lo ao gnaisse do Geossítio } \\
\text { Praia Brava (Arruda et al., 2015). }\end{array}$ \\
\hline $\begin{array}{l}\text { Granitos da } \\
\text { Praia da } \\
\text { Mococa }\end{array}$ & - & $\begin{array}{l}\text { - Explicar a erosão das rochas e como surgiu o afloramento; } \\
\text { - Explorar a presença dos megacristais existentes nos diques. }\end{array}$ \\
\hline
\end{tabular}


Tabela 15 Propostas de medidas estruturais e de atividades educativas e turísticas nos sítios da geodiversidade em Ubatuba.

\begin{tabular}{|c|c|c|}
\hline $\begin{array}{l}\text { Sítio da } \\
\text { Geodiversidade }\end{array}$ & Propostas de medidas estruturais & Propostas de atividades educativas e turísticas \\
\hline $\begin{array}{l}\text { Charnockito da } \\
\text { Cachoeira do } \\
\text { Prumirim }\end{array}$ & $\begin{array}{l}\text { - Cordões de segurança para evitar quedas } \\
\text { nas rochas escorregadias; }\end{array}$ & $\begin{array}{l}\text { - Associar a formação da queda d'água com o processo de } \\
\text { erosão diferencial; } \\
\text { - Explicar o intemperismo e alteração da cor do charnockito. } \\
\text { - Interação dos visitantes com o rio Prumirim a partir da } \\
\text { trilha que dá acesso à visitas na Aldeia indígena Boa Vista. }\end{array}$ \\
\hline $\begin{array}{l}\text { Praia da } \\
\text { Fazenda }\end{array}$ & - & $\begin{array}{l}\text { - Passeio de barco no mangue pelo Rio Fazenda explicando } \\
\text { como se dá a sedimentação e deposição fluvial; } \\
\text { - Explicar intemperismo e erosão a partir dos blocos } \\
\text { dispostos próximo ao costão; } \\
\text { - Utilizar os diques para abordar a abertura do } \\
\text { Supercontinente Gondwana; } \\
\text { - Relacionar os grãos do costão com os grãos da areia da } \\
\text { praia; } \\
\text { - Abordar a mineralogia da areia da praia, observação dos } \\
\text { minerais pesados; } \\
\text { - Explicar como se formam as marcas onduladas na areia da } \\
\text { praia. }\end{array}$ \\
\hline $\begin{array}{l}\text { Mirante do } \\
\text { Engenho }\end{array}$ & $\begin{array}{l}\text { - Painel interpretativo sobre a formação da } \\
\text { Serra do Mar e da Ilha Anchieta. }\end{array}$ & $\begin{array}{l}\text { - Explicar a evolução geomorfológica da Serra do Mar e da } \\
\text { Ilha Anchieta à partir do mirante. }\end{array}$ \\
\hline $\begin{array}{l}\text { Esporão do } \\
\text { Puruba }\end{array}$ & $\begin{array}{l}\text { - Painel interpretativo sobre processos de } \\
\text { deposição fluvial e formação de barras e } \\
\text { esporão. }\end{array}$ & $\begin{array}{l}\text { - Explicaçar a formação do esporão a partir da abordagem } \\
\text { da deposição fluvial; } \\
\text { - Explicar a deposição dos minerais pesados e a } \\
\text { estratificação apresentada no perfil da margem do rio. }\end{array}$ \\
\hline Praia da Lagoa & - & $\begin{array}{l}\text { - Abordar os aspectos geomorfológicos da lagoa; } \\
\text { - Utilizar as ruínas da Lagoa para falar do patrimônio } \\
\text { construído do litoral norte e a utilização das rochas em } \\
\text { construções. }\end{array}$ \\
\hline $\begin{array}{l}\text { Praia das } \\
\text { Conchas }\end{array}$ & - & $\begin{array}{l}\text { - Explicar a coloração rosada do charnockito a partir da } \\
\text { abordagem do intemperismo na rocha. }\end{array}$ \\
\hline
\end{tabular}

\section{Conclusão}

A partir do processo seletivo dos sítios da geodiversidade com potencial para uso educacional e turístico, foi possível chegar ao resultado de 25 sítios da geodiversidade inventariados no litoral norte do estado de São Paulo. Estes sítios foram descritos em relação aos aspectos da geodiversidade e quantificados a fim de gerar valores numéricos referentes ao potencial de uso e ao risco de degradação.

O método de seleção dos sítios da geodiversidade mostrou-se eficiente em todas as etapas, sendo considerado o levantamento inicial dos sítios potenciais ou "préseleção" uma etapa interdisciplinar que exigiu conhecimento tanto na área das geociências quanto na área das ciências sociais. A seleção parcial consistiu em um levantamento geológico mais apurado dos sítios para que na seleção final fosse realizado trabalho de campo apenas nos sítios onde as informações levantadas nas etapas anteriores não foram suficientes para excluir ou classificar o sítio. 
O método de quantificação escolhido (CPRM, 2016) mostrou-se proporcional às expectativas iniciais, porém com alguns impasses encontrados no momento de valorar determinados parâmetros, como "Beleza Cênica" e "Singularidade". Estes dois parâmetros mostraram-se inequiparáveis ao território brasileiro, que por se tratar de um país com uma área muito extensa, a valoração desses parâmetros torna-se muito difícil de ser avaliada e sempre acaba apresentando valores baixos. Os parâmetros "Potencial didático" e "Potencial para divulgação" mostraram-se fora da realidade educacional brasileira visto que, no ensino básico, as geociências são apresentadas superficialmente nas disciplinas de geografia e/ou ciências, sem o devido aprofundamento nos fundamentos da geologia e história geológica da Terra.

Outra dificuldade apresentada no método de análise quantitativa foi na quantificação de sítios do tipo mirantes, não ficando claro se o que estava sendo analisadoera o ponto referente ao mirante ou a paisagem visualizada a partir deste. Sendo assim, optou-se neste trabalho quantificar elementos geológicos relativos à paisagem visualizada.

A partir dos resultados obtidos com a quantificação para uso educacional e/ou turístico, somado ao risco de degradação inerente a cada um deles, foram propostas formas de uso desses sítios, considerando suas principais potencialidades e levando em conta suas fragilidades.

Com os resultados obtidos neste trabalho, foi possível propor medidas estruturais em alguns sítios, e foram propostas atividades turísticas e educacionais para todos eles. Como medida estrutural, painéis de divulgação constituem o método mais eficiente para expor os aspectos geológicos no sítio nesta região. A princípio, alguns sítios não apresentam necessidade de medidas estruturais, visto que as atividades propostas suprem a demanda de informação sobre a geodiversidade do local. É preciso ter em mente que as propostas de medidas estruturais e de atividades são dinâmicas, podem mudar de acordo com novas necessidades.

As medidas estruturais e propostas de atividades sugeridas neste trabalho são realistas às atuais condições de aplicação nesta região. Porém, o ideal para todas as regiões onde são feitos este tipo de levantamento geológico seria a instalação de um centro interpretativo, ao qual disponibilizaria informações sobre a geodiversidade, as rotas de acesso, as trilhas e a logística disponível (hotéis e restaurantes).

O inventário e quantificação dos sítios da geodiversidade mostraram-se essenciais para direcionar políticas de gestão de uso do meio natural, apresentando a 
geoconservação como uma ciência interdisciplinar, que necessita de conhecimentos e intervenções de diversas áreas das ciências sociais para ser concretizada. Este tipo de estudo mostra-se importante para esclarecer como os sítios da geodiversidade podem servir para o uso construtivo, gerando conhecimento e desenvolvimento para as comunidades que passam a valorar estas áreas de importante interessse geocientífico. $\mathrm{O}$ intuito é fazer com que tanto a biodiversidade como a geodiversidade passem a ser correlacionadas e conservadas mutuamente, de modo a proceder com a manutenção de um ambiente sustentável.

\section{Agradecimentos}

Os resultados deste trabalho são parte da Tese de Doutoramento da primeira autora junto ao Programa de Pós-Graduação Geociências (Mineralogia e Petrologia), do Instituto de Geociências da Universidade de São Paulo. As autoras agradecem o apoio da Pró-Reitoria de Pesquisa da Universidade de São Paulo, por meio do Programa de Incentivo à Pesquisa, que permitiu a criação do Núcleo de Apoio à Pesquisa em Patrimônio Geológico e Geoturismo (GeoHereditas), ao Conselho Nacional de Desenvolvimento Científico e Tecnológico (CNPq) pela bolsa de doutorado concedida, à Fundação de Amparo à Pesquisa do Estado de São Paulo (FAPESP) por meio do Processo 2011/17261-6 e à pesquisadora Rachel Prochoroff por disponibilizar informações essenciais sobre a geodiversidade do município de Ilhabela.

\section{Referências}

Almeida, F.F.M. 1976. The system of continental rifts bordering the Santos Basin, Brazil. Anais da Academia Brasileira de Ciências, 48: 15 - 26.

Almeida, F.F.M. \& Carneiro, C.D.R. 1998. Origem e Evolução da Serra do Mar. Revista Brasileira de Geociências, 28 (2): 135 - 150.

Arana, R.; Rodríguez Estrella, T.; Mancheño, M.A. \& Ortiz Silla, R. 1992. Lugares de interés geológico de la Región de Murcia. Murcia, Agencia regional para el medio ambiente y naturaleza. 219p. 
Arruda, K.E.C.; Garcia, M.G.M. \& Del Lama, E.A. 2015. Geological Heritage Inventory as a Subsidy for Geotourism: Caraguatatuba - São Paulo State, Brazil. In: INTERNATIONAL PROGEO SYMPOSIUM, 8, Reykjavik, 2015. ProGEO programme and abstracts, Reykjavik, p. 68-69.

Asmus, H.E. \& Ferrari, A.L. 1978. Hipótese sobre a causa do tectonismo cenozóico na região sudeste do Brasil. In: Aspectos estruturais da margem continental leste e sudeste do Brasil, Rio de Janeiro, CENPES/DINTEP, p.75-88. (Série Projeto REMAC 4).

Barreto, G.S. 2012. Geologia e tectônica da porção oeste da Ilha de São Sebastião, SP e a comparação com as áreas continentais adjacentes. Universidade de São Paulo, Trabalho de Conclusão de Curso, 65p.

Brilha, J. 2005. Patrimônio Geológico e Geoconservação: A conservação da natureza na sua vertente geológica. Braga. Palimage (ed), 173p.

Brilha, J. 2016. Inventory and Quantitative Assessment of Geosites and Geodiversity Sites: a Review. Geoheritage, 8(2): 119-134.

Burek, C.V. \& Prosser, C.D. 2008. The history of geoconservation. London, Geological Society. 312 p.

CPRM. Serviço Geológico do Brasil. 2016. Geossit: cadastro de sítios geológicos. Disponível em: http://www.cprm.gov.br/geossit.

Dixon, G. 1996. A Reconnaissance Inventory of Sites of Geoconservation Significance on Tasmanian Islands. Hobart, Parks and Wildlife Service. 116 p.

Duque, L.C.; Murcia, V.; Abril, J.; García Salinas, F. \& Elízaga, E. 1978. Proyecto previo de puntos de interés geológico. Madrid, Instituto Geológico y Minero de España. 47 p. 
García-Cortés, A. \& Carcavilla-Urquí, L. 2009. Documento metodológico para la elaboración del inventario español de lugares de interés geológico (IELIG), Intituto Geológico y Minero de Espanã, Madrid, versión 11, 61p.

Garda, G.M. 1995. Os Diques Básicos e Ultrabásicos da região costeira entre as cidades de São Sebastião e Ubatuba, Estado de São Paulo. Programa de Pósgraduação em Mineralogia e Petrologia, Universidade de São Paulo, Tese de Doutorado, 156p.

Gray, M. 2004. Geodiversity: Valuing and conserving abiotic nature. Londres, John Wiley \& Sons. 434 p.

Gray, M. 2013. Geodiversity: Valuing and conserving abiotic nature. Londres, John Wiley \& Sons. 508 p.

Guimarães, T.O. 2016. Patrimônio geológico e estratégias de geoconservação: popularização das geociências e desenvolvimento territorial sustentável para o litoral sul de Pernambuco (BRASIL). Programa de Pós-graduação em Geociências, Universidade Federal de Pernambuco, Tese de Doutorado, 359p.

Heilbron, M. \& Machado, N. 2003. Timing of terrane accretion in the NeoproterozoicEopaleozoic Ribeira orogen (SE Brazil). Precambrian Research, 125 (1-2): 87 112.

Heilbron, M.; Valeriano, C.M.; Tassinari, C.C.G.; Almeida, J.C.H.; Tupinambá, M.; Siga Jr. O. \& Trouw, R.J.A., 2008. Correlation of Neoproterozoic terranes between the Ribeira Belt, SE Brazil and its African counterpart: comparative tectonic evolution and open questions. In: PANKHURST, R.J., TROUW, R.A.J., BRITO NEVES, B.B., DE WIT, M.J. (ed.) West Gondwana Pre-Cenozoic Correlations across the South Atlantic Region. The Geological Society of London, p. 211-237. 
Kozlowski S. 2004. Geodiversity. The concept and scope of geodiversity. Przeglad Geologiczny, 52 (8/2): 833 - 837.

Lago, M.; Arranz, E.; Andrés, J.A.; Soria, A.R. \& Galé, C. 2001. Patrimonio Geológico: bases para su estudio y metodología. Zaragoza, Publicaciones del Consejo de Protección de la Naturaleza de Aragón. 107 p.

Maffra, C.Q.T. 2000. Geologia estrutural do embasamento cristalino na região de São Sebastião, SP: evidências de um domínio transpressivo. Programa de Pósgraduação em Geoquímica e Geotectônica, Universidade de São Paulo, Dissertação de Mestrado, 113p.

Melo, M.S. \& Pires Neto, A.G. 1977. Esboço geológico da província costeira entre as Serras do Juqueriquerê e Parati, Estado de São Paulo. In: SIMPÓSIO REGIONAL DE GEOLOGIA, 1, São Paulo, 1977. Anais do $1^{o}$ Simpósio Regional de Geologia, São Paulo, SOCIEDADE BRASILEIRA DE GEOLOGIA, p. 303-323.

Mora, C.A.S.; Campanha, G.A.C. \& Wemmer, K. 2013. Microstructures and K-Ar illite fine-fraction ages of the cataclastic rocks associated to the Camburu Shear Zone, Ribeira Belt, Southeastern Brazil. Brazilian Journal of Geology, 43 (4): 607 622.

Mucivuna, V.C. 2016. Estratégias de geoconservação aplicadas à geodiversidade do município de Bertioga-SP e às fortificações do litoral paulista. Programa de Pós-graduação em Mineralogia e Petrologia, Universidade de São Paulo, Dissertação de Mestrado, 142p.

Neumann, R. 1993. Contribuição à Petrologia das Rochas Charnockíticas de Ubatuba, Leste do Estado de São Paulo. Programa de Pós-graduação em Mineralogia e Petrologia, Universidade de São Paulo, Dissertação de Mestrado, 86p. 
Nieto, L.M. 2001. Geodiversidad: propuesta de una definition integradora. Boletin geológico y minero, $112(2): 3$ - 12.

Perrotta, M.M.; Salvador, E.D.; Lopes, R.C.; D'Agostinho, L.Z.; Peruffo, N.; Gomes, S.D.; Sachs, L.L.B.; Meira, V.T.; Garcia, M.G.M. \& Lacerda Filho, J.V. 2005. Mapa geológico do estado de São Paulo. São Paulo, Serviço Geológico do Brasil, escala 1:750.000.

Prochoroff, R. 2014. Patrimônio geológico de Ilhabela-SP.: estratégias de geoconservação. Programa de Pós-graduação em Mineralogia e Petrologia, Universidade de São Paulo, Dissertação de Mestrado, 176p.

Reverte, F.C. 2014. Avaliação da Geodiversidade em São Sebastião-SP, com Patrimônio Geológico. Programa de Pós-graduação em Mineralogia e Petrologia, Universidade de São Paulo, Dissertação de Mestrado, 208p.

Reverte, F.C. \& Garcia, M.G.M. 2016. O patrimônio geológico de São Sebastião - SP: inventário e uso potencial de geossítios com valor científico. Geociências, 35 (4): $495-511$.

Santos, P.L.A. 2014. Patrimônio Geológico em Áreas de Proteção Ambiental: Ubatuba - SP. Programa de Pós-graduação em Mineralogia e Petrologia, Universidade de São Paulo, Dissertação de Mestrado, 207p.

Santos, E.M. 2016. A geoconservação como ferramenta para o desenvolvimento sustentável em regiões semiáridas: estudo aplicado à Mesorregião do Agreste de Pernambuco, Nordeste do Brasil. Programa de Pós-Graduação em Geociências, Universidade Federal de Pernambuco, Tese de Doutorado, 242p.

Seade. Fundação Sistema Educacional Análise de Dados. 2011. Informações dos Municípios Paulistas. Disponível em: Fundação Sistema Educacional Análise de Dados: http://produtos.seade.gov.br/produtos/imp/. 
Serrano, E. \& Ruiz-Flaño, P. 2007. Geodiversity: a theoretical and applied concept. Geographica Helvetica, 62 (3): 140 - 147.

Stanley, M. 2001. Geodiversity. Earth Heritage, 14: 15 - 18.

Teixeira, L.R.; Legaspe, L.B.C. \& Milanelli, J.C.C. 2011. Gestão Integrada de Grandes Empreendimentos: O Desafio do Litoral Norte do Estado de São Paulo. In: SIMPÓSIO BRASILEIRO DE OCEANOGRAFIA - OCEANOGRAFIA E POLÍTICAS PÚBLICAS, 5, Santos, 2011. Oceanografia e políticas públicas, Santos, p. $15-18$.

Tupinambá, M.; Heilbron, M.; Valeriano, C.; Porto Júnior, R.; Blanco de Dios, F.; Machado, N.; Eirado Silva, L.G. \& Almeida, J.C.H. 2012. Juvenile contribution of the Neoproterozoic Rio Negro Magmatic Arc (Ribeira Belt, Brazil): Implications for Western Gondwana Amalgamation. Gondwana Research, 21 (2-3): 422-438.

Wimbledon, W.A.P.; Andersen, S.; Cleal, C.J.; Cowie, J.W.; Erikstad, L.; Gonggrijp, G.P.; Johansson, C.E.; Karis, L.O. \& Suominen, V. 1999. Geological World Heritage: GEOSITES - a global site inventory to enable prioritisation for conservation. In: SYMPOSIUM OF THE EUROPEAN ASSOCIATION FOR THE CONSERVATION OF THE GEOLOGICAL HERITAGE, 2, Trento, 1997. Memoire Del Servizio Geologico d'Italia, Trento, p. 45-60.

Zalán, P.V. \& Oliveira, J. A. B. 2005. Origem e evolução estrutural do sistema de riftes cenozoicos do sudeste do Brasil. Boletim de Geociências da Petrobras, 13 (2): $269-300$. 


\author{
ARRUDA, K.E.C.; GARCIA, M.G.M.; DEL LAMA, E.A. 2017. Inventário \\ Geológico do Patrimônio Construído no Litoral Norte do Estado de São \\ Paulo, Brasil. Boletim Paranaense de Geociências, Paraná, 73 (1): 15-33.
}

\title{
Inventário Geológico do Patrimônio Construído no Litoral Norte do Estado de São Paulo, Brasil
}

\author{
Geological Inventory of the Built Heritage on the Northern Coast \\ of São Paulo State, Brazil
}
KARLLA EMMANUELLE CUNHA ARRUDA ${ }^{1}$, MARIA DA GLÓRIA MOTTA GARCIA ${ }^{1}$, ELIANE APARECIDA DEL LAMA ${ }^{1}$

1Universidade deSãoPaulo-USP,SãoPaulo-karllaemmanuelle@hotmail.com, mgmgarcia@usp.br, edellama@usp.br

\begin{abstract}
Resumo: A geodiversidade está presente em todas as esferas do planeta, incluindo a urbana, desde a ocupação das cidades baseada no relevo, até os materiais utilizados nas construções. Este trabalho discorre sobre a relação entre o patrimônio construído e a geodiversidade dos materiais pétreos utilizados nas construções e monumentos de 4 municípios do litoral norte paulista: São Sebastião, Ilhabela, Caraguatatuba e Ubatuba. Foram analisadas em campo 31 construções na região, dentre as quais 13 receberam a denominação de Patrimônio Construído por apresentarem em sua construção materiais pétreos com aspectos geológicos relevantes. Com base no levantamento dos materiais pétreos pode-se concluir que a maioria dessas construções foram edificadas com pedra e cal conchífera locais, como é o caso de Ilhabela, com sienito, Ubatuba, com charnockito, São Sebastião, com gnaisse migmatítico, e Caraguatatuba, com gnaisse granítico milonítico. As formas de degradação da pedra podem ser visualizadas nessas construções, como intemperismo, eflorescência, umidade, manchamento, fraturas, aspecto brilhante e colonização biológica. A utilização desse patrimônio em termos de divulgação geocientífica mostra-se de grande eficácia para atingir a parte da população que não pode ou não possui o hábito de visitar parques e áreas naturais, pois passam a maior parte do tempo no meio urbano, sem contato direto com a natureza.
\end{abstract}

Palavras-Chave: Patrimônio Construído; Geologia; Divulgação Geocientífica.

Abstract: Geodiversity is present in all environments of the planet, including urban, from the occupation of cities based on relief, to the materials used in constructions. This work deals with the relationship between built heritage and geodiversity found in stone materials used in constructions and monuments in 4 municipalities on the northern coast of São Paulo State: São Sebastião, Ilhabela, Caraguatatuba and Ubatuba. A total of 31 buildings were analyzed in the region, of which 13 were categorized as Built Heritage based on the presence of stone materials with relevant geological aspects in their construction. Based on the inventory of the stone materials it can be concluded that most of these constructions were built with stones and shelly lime, the stones obtained mainly from the local geodiversity, as is the case of Ilhabela's syenite, Ubatuba's 
charnockite, São Sebastião's migmatitic gneiss, and Caraguatatuba's mylonitic granitic gneiss. Forms of stone degradation can be seen in these constructions, such as weathering, efflorescence, humidity, staining, fractures, shiny appearance and biological colonization. The use of this heritage in terms of geoscientific dissemination proves to be very effective in reaching the part of the population that cannot or is not in the habit of visiting parks and natural landscapes, since they spend most of their time in the urban environment, with no direct contact with nature.

Key-Words: Built Heritage; Geology; Diffusion of geoscience.

\section{Introdução}

A geodiversidade está presente em todas as esferas do planeta, incluindo a esfera urbana, com a ocupação das cidades baseadas na geografia local, até os materiais utilizados nas construções e os espaços de lazer. O local de assentamento das cidades é definido de acordo com as facilidades geográficas, como topografia e hidrografia, solos e agricultura e, em alguns casos, pela presença de riquezas minerais.

O conceito de geodiversidade é usualmente definido como a gama natural de processos geológicos, geomorfológicos e características do solo, incluindo suas interrelações (Gray 2004). Entretanto, a geodiversidade de uma região tem importância não só geológica, mas também cultural, estando presente na memória social de um povo que, ao recordar uma determinada região, recorre às memórias associadas aos aspectos geográficos da paisagem (montanhas, colinas, praias, solo, etc.), incluindo as construções existentes naquele local.

Weber et al. (2016) consideram que edifícios, monumentos e outros recursos artificiais construídos com materiais geológicos são inteiramente consistentes com o conceito de geodiversidade. Em Brilha (2016), a denominação de "elementos do patrimônio geológico" - é dada para ocorrências geológicas ex situ com relevante valor científico, e "elementos da geodiversidade" - para ocorrências geológicas ex situ contendo outros valores relevantes (cultural, turístico, etc.). Embora adote termos diferentes, o autor considera esses elementos geológicos inseridos dentro do conceito de geodiversidade. Neste trabalho, o termo "patrimônio construído" é definido como construções ex situ de origem antrópica que apresentam em sua composição materiais geológicos e que possuam relativa importância para a geologia ou cultura local.

Este trabalho discorre sobre a relação entre o patrimônio construído nos municípios do litoral norte do estado de São Paulo e a diversidade litológica encontrada nessas construções e monumentos. Tem como principal escopo a disseminação da ideia de que 
os elementos da geodiversidade estão presentes no dia-a-dia das pessoas nas áreas urbanas e não apenas em áreas naturais distantes e isoladas. Algumas construções e ruínas representam importantes patrimônios históricos na região, apresentando um potencial para se explorar não só a história, mas também a geodiversidade, por meio dos materiais de construção que incluem diferentes rochas utilizadas de acordo com o momento econômico e cultural.

A divulgação da geodiversidade por meio da utilização das pedras nas construções urbanas vem ganhando cada vez mais espaço. Um dos primeiros trabalhos sobre a geologia urbana surgiu em Londres na década de 1980 (Robinson \& Bishop 1980, Robinson 1982, 1984, 1985, 1987, 1988, 1993, 1997), com a criação de trilhas geológicas urbanas, apresentando as rochas e minerais utilizados nas edificações de Londres.

No Brasil, a ideia de trilhas geológicas urbanas vem sendo trabalhada desde 2006 (Stern et al. 2006) e teve seguimento em Reys et al. (2008), Liccardo et al. (2008), Mansur et al. (2008), Del Lama et al. (2009), Philipp et al. (2009), Carvalho (2010), Augusto \& Del Lama (2011), Del Lama et al. (2015), Pinto (2015) e Nascimento et al. (2016). Entretanto, trata-se de uma área da geociência pouco divulgada, Del Lama et al. (2015) alertam para a influência da falta de recursos e o pouco investimento em cultura e educação como um fator limitante para a divulgação geocientífica no Brasil, assim como o pouco interesse da comunidade geológica em popularizar a ciência. Liccardo et al. (2012) afirmam que uma das principais limitações da divulgação das geociências é o distanciamento das pessoas em relação à natureza, visto que, segundo o último censo, $84,35 \%$ da população brasileira vive hoje em ambiente urbano (IBGE 2010).

Sendo assim, devido à dificuldade de deslocamento para áreas naturais em algumas regiões, pode-se levar um pouco da informação da geodiversidade presente no meio urbano, onde está concentrada a maior parte da população, tornando mais acessível o conhecimento geológico exemplificado pelos minerais e rochas existentes nas construções e monumentos, a fim de estimular o observador, por meio deste conhecimento, a conservar não só o patrimônio natural mas também o patrimônio construído.

Alguns pesquisadores trataram de sistematizar o estado de conservação das rochas em edificações. Entre eles, destacam-se Aires-Barros (1991), que estudou as rochas portuguesas, e Fitzner \& Heinrichs (2004), que avaliaram como ocorre a deterioração em rochas nos monumentos. Mais recentemente, os trabalhos estão inserindo estas 
edificações pétreas em roteiros geológicos. O principal objetivo deste tipo de estudos é acrescentar informação geológica ao turismo já existente nas cidades, inserindo um novo olhar sobre o patrimônio construído, também conhecido como Geoturismo Urbano, e consequentemente auxiliando na educação e divulgação das geociências.

Neste trabalho foram analisados e estudados em campo 31 pontos de construções representativas na história do litoral norte do estado de São Paulo. Dentre estas construções, apenas 13 receberam a denominação de patrimônio construído, sendo eles: Casa Esperança, Sítio Morro do Abrigo, Paróquia Nossa Senhora do Amparo, Sítio Histórico São Francisco, Paróquia Nossa Senhora D’Ajuda, Antigo Mercado de Escravos, Paróquia Matriz Santo Antônio, Relógio do Sol, Ruínas da Lagoinha, Ruínas do Ipiranguinha, Sobradão do Porto, Monumento em Homenagem ao Caiçara e Antiga Pedreira de Itamambuca. Como os demais pontos não apresentaram interesse geológico em seus materiais de construção e/ou de revestimento por não apresentarem rochas em bom estado de conservação ou com alguma relevância científica para a pesquisa, não foram incluídos neste trabalho.

\section{Caracterização da Área de Estudo}

O litoral norte do estado de São Paulo abrange uma área de aproximadamente 2.000 $\mathrm{km}^{2}$ (Figura 1).

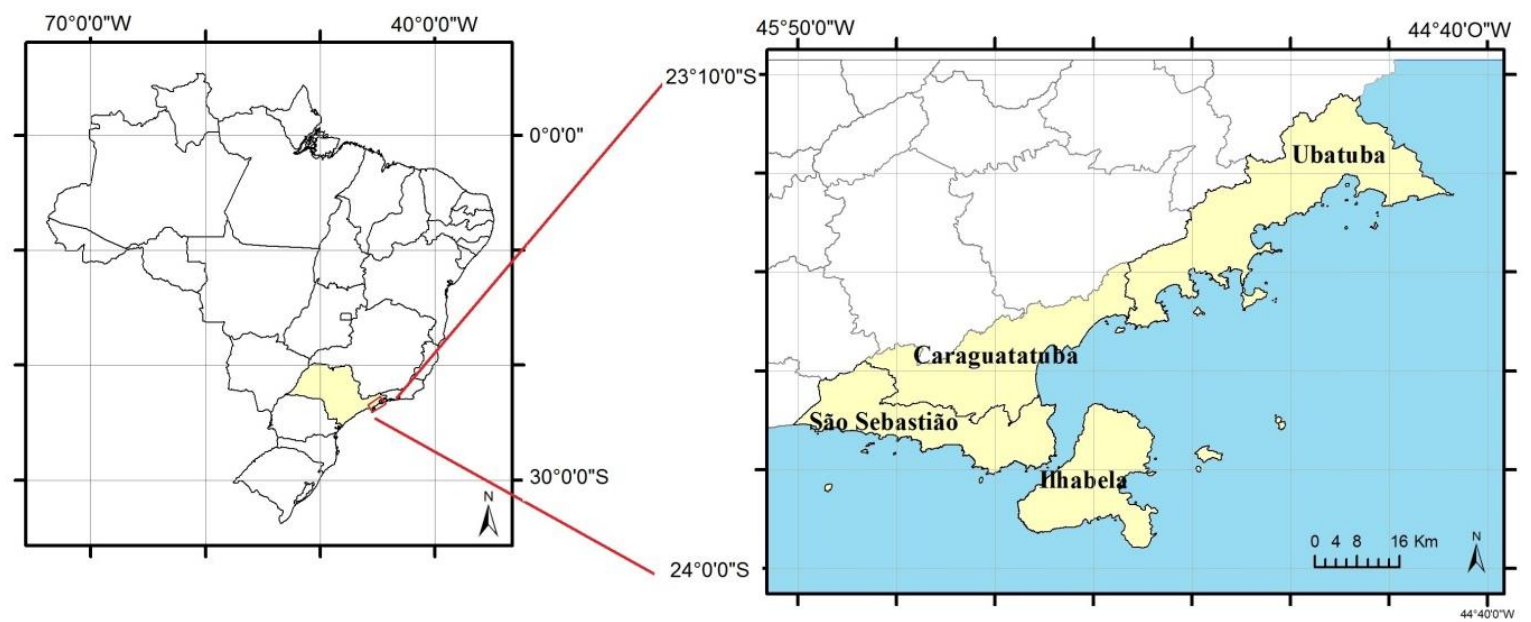

Figura 1. Localização geográfica do litoral norte do estado de São Paulo, abrangendo os municípios de Ubatuba, Caraguatatuba, São Sebastião e Ilhabela.

\subsection{Geologia}

Geologicamente, a área de estudo está inserida como parte da Província Mantiqueira (Almeida et al. 1977), de idade Neoproterozoica, subdividida em várias unidades 
geológicas, incluindo o Domínio Costeiro (Heilbron et al. 2004), onde está mais precisamente a área de estudo. Esta unidade é delimitada, a norte, pela Falha de Cubatão e a sul, pela linha de costa e ilhas vizinhas. Sua evolução geomorfológica está relacionada ao estágio de reativação da plataforma brasileira, do Neojurássico ao recente (Almeida 1969).

Esse estágio de reativação tem relação direta com a fragmentação do Supercontinente Gondwana e abertura do Oceano Atlântico Sul, com a posterior formação da Serra do Mar e a forma da costa brasileira, assim como foi responsável pelo intenso e variável magmatismo representado pelos diques básicos e intermediários, e por stocks e diques de rochas alcalinas (Perrota et al. 2005) (Figura 2).

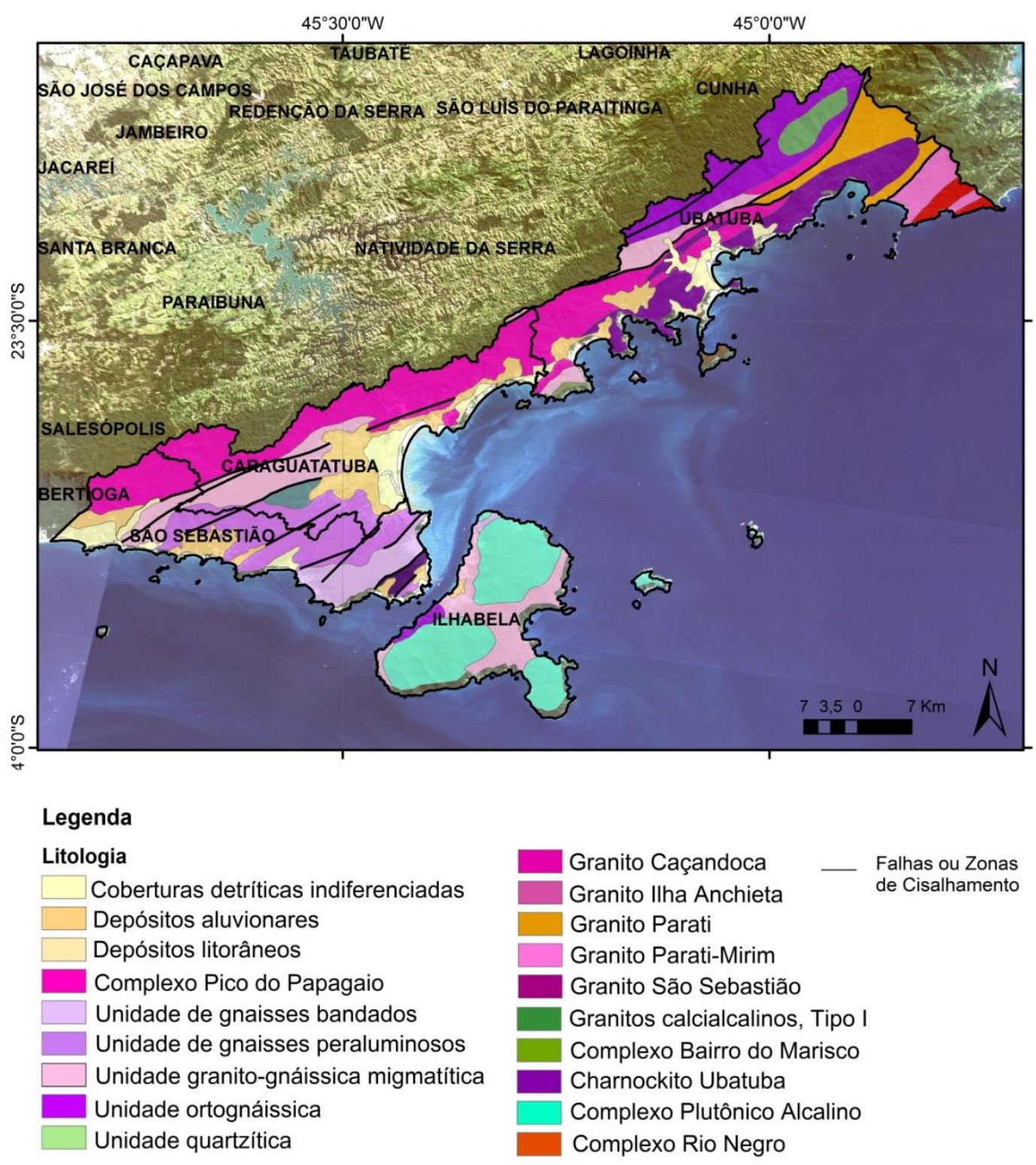

Figura 2. Mapa Geológico da área de estudo. Adaptado de Perrota et al. (2005). 
O Domínio Costeiro é composto de ortognaisses, gnaisses bandados, migmatitos, rochas granulíticas (São Sebastião), micaxistos, quartzitos arcoseanos, rochas calciossilicáticas, e intrusões tardi- a pós-tectônicas de granitoides e charnockitoides (Ubatuba) (Heilbron et al. 2004). Ocorrem ainda pequenos corpos de anfibolito derivados de toleítos continentais formados há 580 Ma e metamorfizados há $570 \mathrm{Ma}$ (Dias Neto et al. 2006).

As coberturas cenozoicas estão representadas pelas áreas de planície costeira, onde ocorrem depósitos flúvio-lagunares, coluviais, detríticos com areia, silte, argila e cascalho, e depósitos litorâneos ou marinhos de areia, silte e argila.

O patrimônio geológico da região é constituído por 35 geossítios (Reverte 2014, Prochoroff 2014, Santos 2014, Arruda et al. 2015, Reverte \& Garcia 2016), representando majoritariamente rochas graníticas e gnáissicas. Foram inventariados também mirantes, de onde se podem observar e descrever aspetos geomorfológicos locais.

\subsection{Geomorfologia}

Os aspectos geomorfológicos da região são dominados pela Serra do Mar e caracterizados por um conjunto de escarpas que marcam a borda oriental dos terrenos pré-cambrianos do Planalto Atlântico (Cruz 1990), e pela planície costeira, com o município de Caraguatatuba possuindo a maior largura, cerca de $10 \mathrm{~km}$, do sopé da Serra do Mar ao oceano. A planície costeira desenvolve-se sobretudo em função do recuo das vertentes das escarpas serranas, das variações do nível do mar e do remanejamento e deposição dos sedimentos transportados pelas correntes marinhas na plataforma continental.

A região abrange uma parte do Parque Estadual da Serra do Mar - PESM, uma área de aproximadamente 332.000 hectares de conservação da Mata Atlântica dentro do estado de São Paulo, possuindo trilhas e atividades ecoturísticas em meio à elevada biodiversidade sobre as escarpas da Serra do Mar.

\subsection{Aspectos Socioeconômicos}

A história socioeconômica do litoral norte de São Paulo remete aos primórdios do período colonial e está diretamente ligada aos fatores geográficos e recursos geológicos disponíveis, como a instalação do porto em Ubatuba e posteriormente em São Sebastião, 
a exploração mineral e o turismo direcionado às zonas de praia a partir da década de 1950.

Segundo Scifoni (2006), são as atividades ligadas ao lazer e, dentro deste conjunto mais amplo o turismo de sol e mar, que movimentam a economia dos municípios do litoral norte, quais sejam São Sebastião, Ilhabela, Caraguatatuba e Ubatuba, e consequentemente a dinâmica da produção deste espaço geográfico. Os valores referentes à população flutuante anual nos 4 municípios são de 100.000 a 230.000 (Seade 2011), representando a importância do turismo na região.

A população na região cresce a uma taxa geométrica anual superior à média registrada para o estado de São Paulo (2,26\% a.a. e 1,32\% a.a., respectivamente - Seade 2011). Associada a esta elevada taxa geométrica de crescimento anual da população fixa, soma-se o grande afluxo de turistas (população flutuante), principalmente durante a época de veraneio, sendo esta atividade a principal fonte de renda da região.

\section{Patrimônio Construído no Litoral Norte de São Paulo}

As 13 construções e monumentos selecionados para constituírem o patrimônio construído devido à importância histórica e cultural na região e pela constituição dos materiais pétreos estão representadas na Figura 3. A seleção levou em consideração também a acessibilidade (fácil localização, disponibilidade de acesso e tipo de propriedade), para que o objetivo final de oferecer informação geológica aos visitantes possa ser devidamente cumprido.

A descrição dos materiais pétreos encontrados no patrimônio construído é tratada a seguir e sumarizada na Tabela 1. As formas de deterioração identificadas foram descritas com base no glossário do Icomos (2008).

Tabela 1. Descrição do Patrimônio Construído do litoral norte de São Paulo.

\begin{tabular}{|c|c|c|c|}
\hline $\begin{array}{l}\text { Patrimônio } \\
\text { Construído }\end{array}$ & Município & $\begin{array}{l}\text { Litologias } \\
\text { dominantes }\end{array}$ & Justificativa de seleção \\
\hline Casa Esperança & \multirow{4}{*}{ São Sebastião } & $\begin{array}{l}\text { Gnaisse } \\
\text { migmatítico }\end{array}$ & $\begin{array}{l}\text { Presença de dois tipos de gnaisse migmatítico utilizado no } \\
\text { batente das portas. Um mais máfico com concentrações de } \\
\text { biotita e outro mais félsico contendo cristais de granada. } \\
\text { Desgaste da rocha seguindo a direção da foliação do gnaisse. }\end{array}$ \\
\hline $\begin{array}{l}\text { Paróquia Nossa } \\
\text { Senhora do Amparo }\end{array}$ & & Gnaisse & $\begin{array}{l}\text { Batente das portas constituídos por gnaisse com cristais de } \\
\text { granada e grande quantidade de muscovita. }\end{array}$ \\
\hline Sítio Morro do Abrigo & & $\begin{array}{c}\text { Gnaisse } \\
\text { migmatítico }\end{array}$ & $\begin{array}{l}\text { Blocos de gnaisse migmatítico rico em biotita utilizado nos } \\
\text { muros e colunas da construção. }\end{array}$ \\
\hline $\begin{array}{l}\text { Sítio Histórico São } \\
\text { Francisco }\end{array}$ & & $\begin{array}{l}\text { Gnaisse } \\
\text { migmatítico }\end{array}$ & $\begin{array}{l}\text { Ruínas da construção, disposta em uma área de } \\
\text { aproximadamente } 1.000 \mathrm{~m}^{2} \text {, constituídas predominantemente } \\
\text { de blocos de gnaisse migmatítico. }\end{array}$ \\
\hline $\begin{array}{l}\text { Paróquia Nossa } \\
\text { Senhora D'Ajuda }\end{array}$ & Ilhabela & Sienito & $\begin{array}{l}\text { Muro frontal constituído por blocos de gnaisse granítico, } \\
\text { apresentando porções pegmatíticas. Muro lateral constituído } \\
\text { por blocos de sienito, alguns apresentando auréola de } \\
\text { alteração. A parede externa da Paróquia tem sua construção } \\
\text { original preservada e exposta, apresentando blocos de sienito }\end{array}$ \\
\hline
\end{tabular}




\begin{tabular}{|c|c|c|c|}
\hline & & & na construção. \\
\hline $\begin{array}{l}\text { Antigo Mercado de } \\
\text { Escravos }\end{array}$ & & Sienito & $\begin{array}{l}\text { Construção de importancia histórica contendo vestígios da } \\
\text { parede original, feito com blocos de rochas alcalinas } \\
\text { porfiríticas e sienitos. }\end{array}$ \\
\hline $\begin{array}{l}\text { Paróquia Matriz Santo } \\
\text { Antônio }\end{array}$ & \multirow[t]{2}{*}{ Caraguatatuba } & $\begin{array}{l}\text { Gnaisse } \\
\text { milonítico }\end{array}$ & $\begin{array}{l}\text { Afloramento de gnaisse granítico milonítico de granulação } \\
\text { grossa com ocorrência de bandas de gnaisse de granulação } \\
\text { mais fina, com presença de enclaves. }\end{array}$ \\
\hline Relógio do Sol & & $\begin{array}{c}\text { Gnaisse } \\
\text { milonítico }\end{array}$ & $\begin{array}{l}\text { Base do monumento constituída por placas de granito } \\
\text { oceolar, e gnaisse granítico milonítico bastante estirado. }\end{array}$ \\
\hline Ruínas da Lagoinha & \multirow{5}{*}{ Ubatuba } & Charnockito & $\begin{array}{l}\text { Ruínas históricas constituídas por blocos heterogêneos de } \\
\text { diversos tamanhos e composições litológicas, } \\
\text { predominantemente charnockito, alguns blocos de granito } \\
\text { porfirítico com cristais de feldspato e blocos de gnaisse. }\end{array}$ \\
\hline $\begin{array}{l}\text { Ruínas do } \\
\text { Ipiranguinha }\end{array}$ & & Gnaisse & $\begin{array}{l}\text { Ruínas constituídas de blocos de gnaisse e sem presença de } \\
\text { argamassa, inteiramente lixiviada com o tempo. }\end{array}$ \\
\hline Sobradão do Porto & & Gnaisse facoidal & $\begin{array}{l}\text { Blocos de granada-biotita gnaisse facoidal, com granadas } \\
\text { centimétricas utilizado na fachada das portas. }\end{array}$ \\
\hline $\begin{array}{l}\text { Monumento em } \\
\text { Homenagem ao } \\
\text { Caiçara }\end{array}$ & & Charnockito & $\begin{array}{l}\text { Base do monumento constituída por placas de charnockito } \\
\text { porfirítico. }\end{array}$ \\
\hline $\begin{array}{l}\text { Antiga Pedreira } \\
\text { Itamambuca }\end{array}$ & & Charnockito & $\begin{array}{l}\text { Grandes blocos de charnockito extraídos pela mineração e } \\
\text { abandonados na área de uma antiga pedreira. }\end{array}$ \\
\hline
\end{tabular}

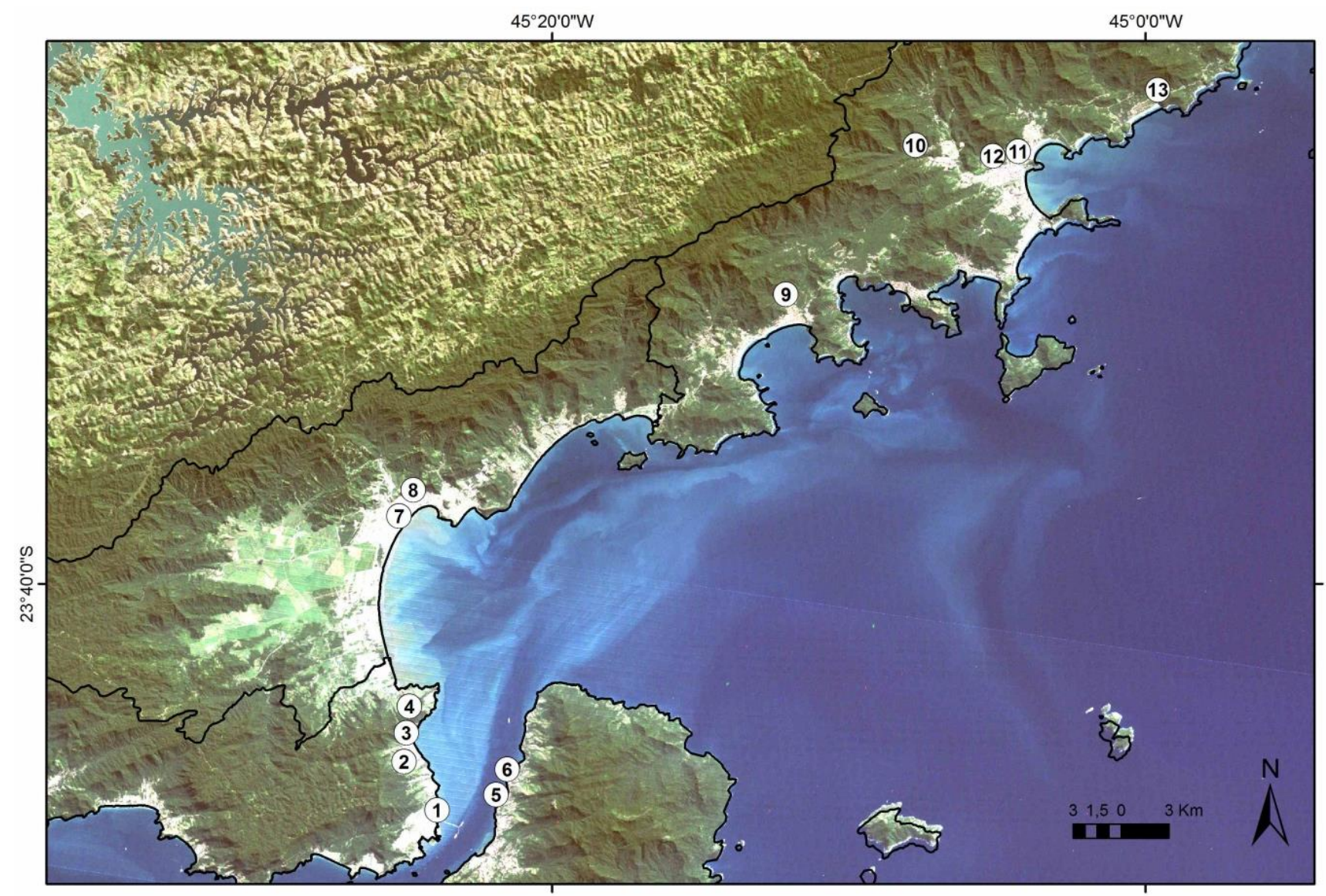

Figura 3. Patrimônio construído no litoral norte do estado de São Paulo. Em São Sebastião: 1 Casa Esperança; 2 - Paróquia Nossa Senhora do Amparo 3 - Sítio Morro do Abrigo; 4 - Sítio Histórico São Francisco. Em Ilhabela: 5 - Paróquia Nossa Senhora D’Ajuda; 6 - Antigo Mercado de Escravos. Em Caraguatatuba: 7 - Paróquia Matriz Santo Antônio; 8 - Relógio do Sol. Em Ubatuba: 9 - Ruínas da Lagoinha; 10 - Ruínas do Ipiranguinha; 11 - Sobradão do Porto; 12 - Monumento em Homenagem ao Caiçara; 13 - Antiga Pedreira de Itamambuca. 


\subsection{São Sebastião}

\section{Casa Esperança}

A Casa Esperança, ou Casa com Teto Pintado, é um sobrado do século XVIII, localizada na Av. Altino Arantes 32, no centro de São Sebastião, nas coordenadas 23K 459443/7367635. Representa a arquitetura urbana colonial (Figura 4.a), construída em tijolo, pedra e cal, apresentando fachada simétrica e ornamentação em pedra, seguindo a padronização portuguesa contida nas Cartas Régias e nas Posturas Municipais, onde as ruas eram definidas pelos sobrados e casas térreas.

A casa pertencia a uma família de imigrantes italianos que montou um comércio chamado Esperança, a residência da família era no andar de cima. Recebeu o nome Casa com Teto Pintado pelo destaque das pinturas de seus tetos no andar térreo, representando cenas mitológicas, alegorias, paisagens e vistas do Rio de Janeiro no início do século XIX (Outeiro da Glória, Passeio Público, entrada da baía e Praça Quinze). Essas pinturas foram feitas durante a reforma de 1838, ocasião em que foram introduzidas as portas balcão e o gradil de ferro da sacada (Sectur 2015).

O sobrado também ficou conhecido pela decoração das três salas nobres do pavimento superior, além das portas trabalhadas em madeira e o gradil da escada.

Foi tombado pelo Iphan (Instituto do Patrimônio Histórico e Artístico Nacional) em 1955, e atualmente funciona como um espaço cultural no andar superior e estabelecimento comercial no piso térreo.

Como elementos geológicos na construção tem-se o batente das portas da casa, constituído a partir de dois tipos de gnaisse migmatítico (Figura 4.b), um mais máfico com concentrações de biotita (Figura 4.c) e outro mais félsico contendo cristais de granada. Os blocos de gnaisse no batente das portas, unidos por camadas de argamassa de cimento visivelmente mal acabada, causam prejuízo na estética da arquitetura original (Figura 4.d).

É possível observar que o desgaste da rocha é feito segundo a direção da foliação do gnaisse (Figuras 4.e e 4.f), que representam áreas de fraqueza da rocha e mais vulneráveis ao intemperismo e erosão.

\section{Paróquia de Nossa Senhora do Amparo}

Está construção está localizada no bairro de São Francisco, em frente à praia de São Francisco nas coordenadas 23K 457674/7372448 (Figura 5.a). Trata-se de uma 
construção do Século XVII edificada em pedra e cal, por mão-de-obra escrava. O edifício passou por uma restauração em 1932 e foi tombado em 1971 pela Condephaat, consistindo atualmente em um Patrimônio Histórico Estadual.

A paróquia está inserida no tour histórico e cultural do Roteiro das Capelas no município e abriga um convento franciscano. As pedras dispostas na atual construção estão localizadas nos batentes de portas e algumas janelas, constituídas de gnaisse com cristais de granada e abundante muscovita (Figura 5.b). A figura 5.c destaca sinais de deterioração das pedras utilizadas nos batentes, como rachaduras e mal acabamento da argamassa entre os blocos. A figura 5.d mostra diferentes tipos de gnaisse (provavelmente substituição em alguma reparação) na porção inferior do batente ligados por argamassa, também mal acabada, sendo o gnaisse disposto abaixo mais rico em granadas e de coloração rosada, e o gnaisse disposto acima com uma maior presença de biotita, apresentando uma coloração mais acinzentada.

\section{Sítio Morro do Abrigo}

O Sítio histórico Morro do Abrigo (Figura 6.a) refere-se a ruínas de uma construção em pedra, tijolo e cal (Figura 6.b) da segunda metade do século XIX, localizado nas coordenadas 23K 457674/7372448, com acesso pela rua Guaratingueta 36, em um bairro residencial e ocupando uma área de aproximadamente $1.000 \mathrm{~m}^{2}$.

Durante o ano de 2006, foi realizado um projeto de reconhecimento arqueológico com o objetivo de delimitá-lo e verificar as áreas de concentração de vestígios arqueológicos existentes em subsuperfície. Nesse caso, foi constatada a existência de um pacote arqueológico com cerca de $30 \mathrm{~cm}$ de profundidade e aproximadamente 25 $\mathrm{m}^{2}$, correspondendo a um bolsão de cultura material, onde os vestígios (cerâmica, faiança, vidro e grés) estão relacionados à segunda metade do século XIX, apontando para uma ocupação posterior ao Sítio São Francisco (Bornal 2008).

As ruínas da construção apresentam muros e colunas constituídas de blocos de gnaisse migmatítico ricos em biotita (Figuras 6.c). Na construção foram utilizados além de rochas, tijolos e argamassa conchífera (Figura 6.d). Atualmente, algumas colunas apresentam evidências de intervenções posteriores na construção, com tijolos (Figura 6.e), e camadas de argamassa e pinturas mais recentes nas paredes. 

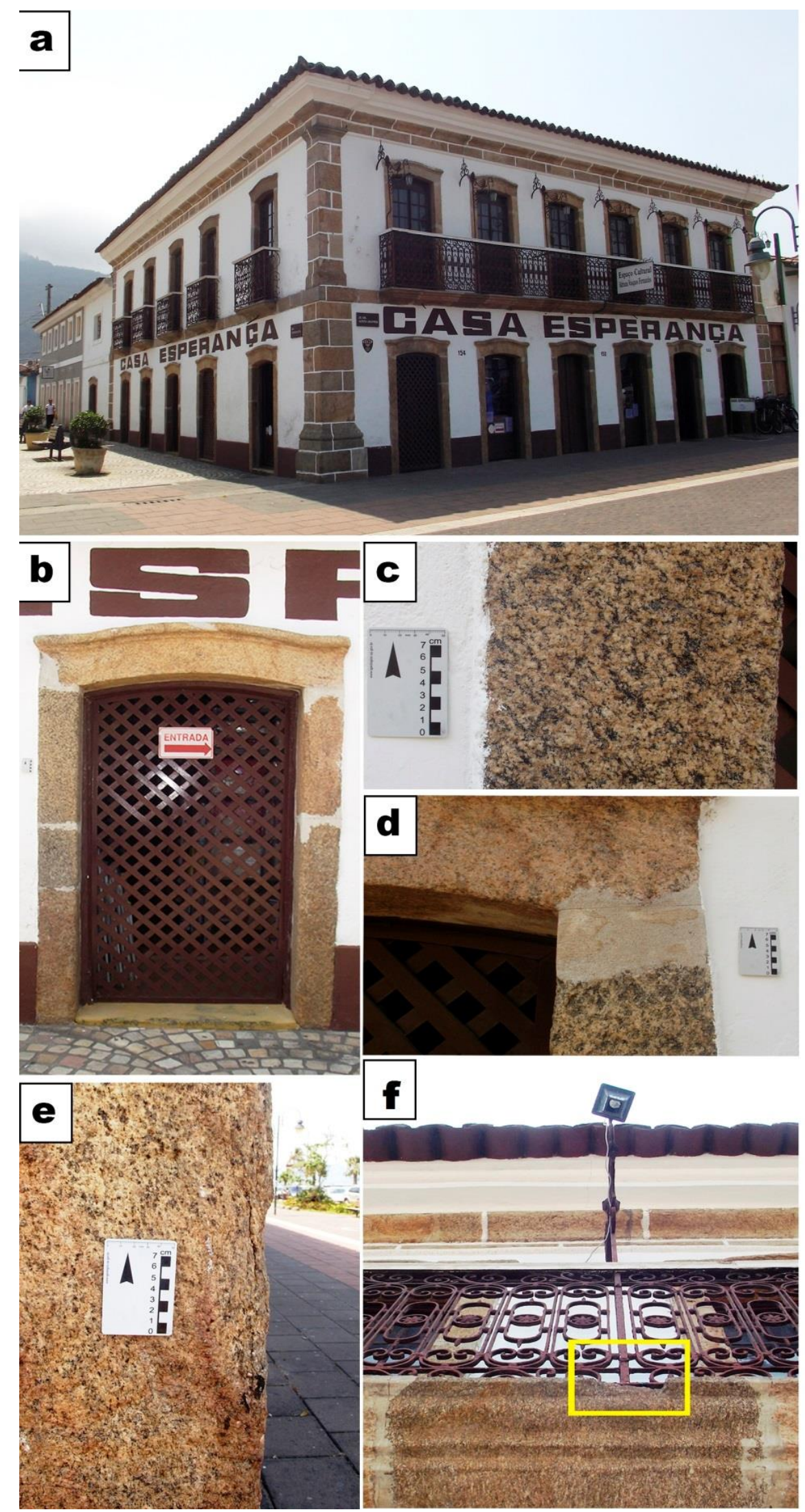

Figura 4. a - Casa Esperança, ou Casa do Teto Pintado, arquitetura urbana colonial do século XVIII em São Sebastião - SP; ; b - batentes das portas constituídos por gnaisse migmatítico; c gnaisse mais máfico, com concentrações de biotita; $\mathrm{d}$ - detalhe do acabamento inadequado de argamassa de cimento sobre o gnaisse; e - desgaste da rocha seguindo as zonas de fraqueza da foliação do gnaisse; $\mathrm{f}$ - detalhe do desgaste da rocha gnássica utilizada no batente superior. 

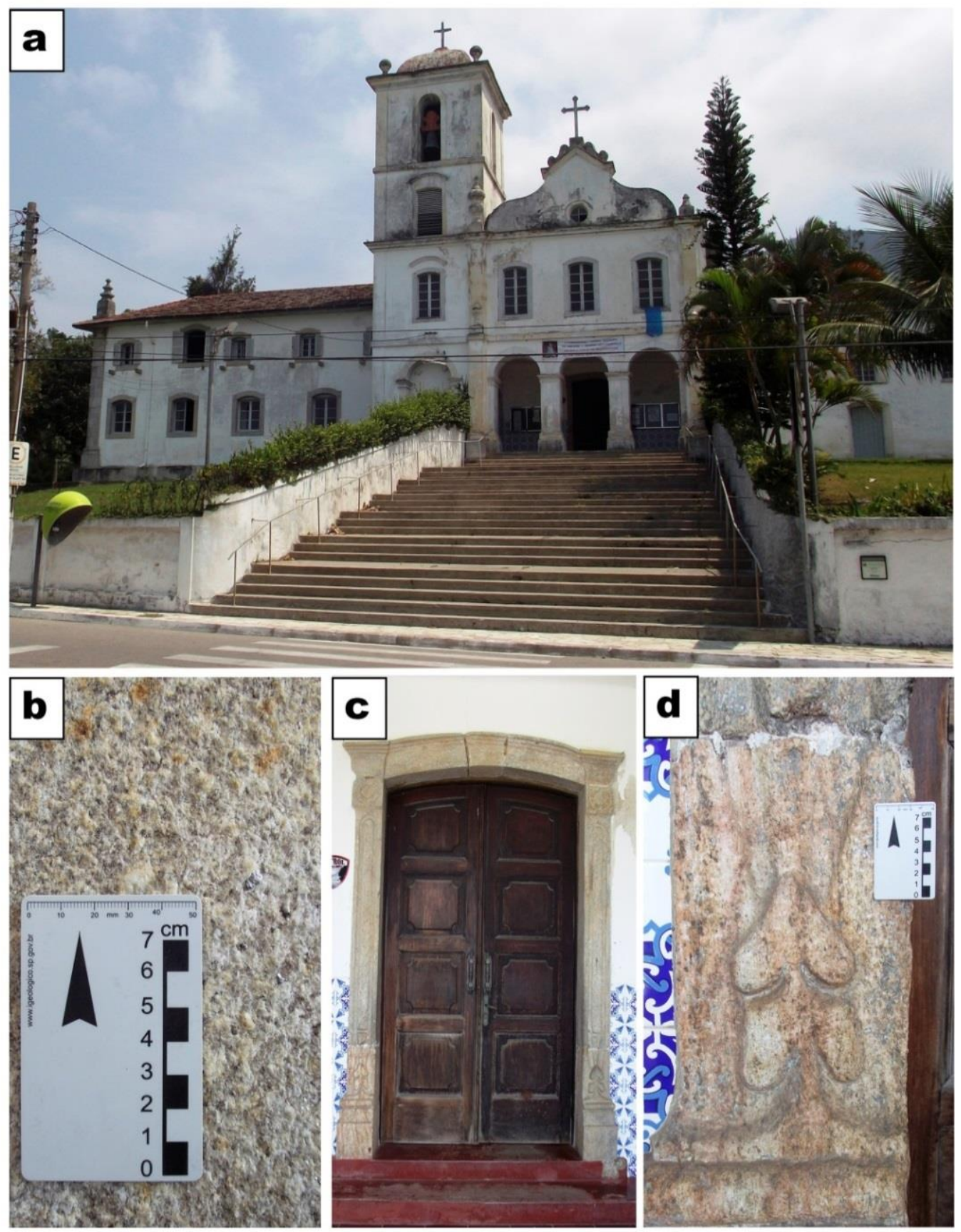

Figura 5. a - Paróquia de Nossa Senhora do Amparo, São Sebastião; b - detalhe do gnaisse utilizado no batente da porta com concentrações de granada e muscovita; c - deterioração do gnaisse, com rachaduras na porção superior do batente; $d$ - utilização de diferentes tipos de rochas ligadas com argamassa mal acabada: acima, maior concentração de biotita e coloração acinzentada; abaixo, gnaisse rico em granada e coloração rosada.

\section{Sítio Histórico São Francisco}

As ruínas do antigo Sítio São Francisco, construído no século XIX, representam o conjunto de vestígios arqueológicos de construções (Figura 7.a) e restos construtivos de unidades habitacionais, religiosas e produtivas, caminhos, estradas, aquedutos e 
barragens, áreas de descarte de objetos e restos alimentares, áreas de plantio e postos de controle que se distribuem por aproximadamente $800.000 \mathrm{~m}^{2}$ (Bornal 2008).

Está localizado nas coordenadas 23K 457799/7374113, situado na Serra do Dom entre as cotas altimétricas 90 e 270 m e inserido no Parque Estadual da Serra do Mar. O acesso é feito pela rodovia Estadual SP-55, na Praia da Figueira em São Sebastião,. Do sítio tem-se a visão do canal de São Sebastião (Figura 7.b) e uma parte de Ilhabela.

Segundo Bornal (2008), vários fatores eram considerados fundamentais para a implantação de uma fazenda de cana ou café na área. A oferta de alguns recursos naturais constituía fator decisivo na escolha da área apta a receber as instalações de determinada unidade produtiva. Sendo assim, considerando as funções econômicas e sociais do sítio, seguramente suas instalações estão diretamente associadas a uma série de elementos, tais como a presença de mata, água, solo fértil e matéria-prima para as construções (pedra, barro e cal).

A construção está localizada parcialmente sobre afloramento de rocha gnáissica migmatizada (Figura 7.c), sendo os blocos de rocha utilizados nas construções provenientes deste local (Figura 7.d). Apesar de o tijolo ter sido utilizado em algumas partes da construção, os blocos de pedra são o principal material de construção, incluindo alguns pisos, como o do salão principal, revestido de blocos de gnaisse migmatítico. A rocha foi utilizada até mesmo para a colocação de arcos na construção referente ao fogão (Figura 7.e), onde comumente nas construções dessa época os arcos são construídos utilizando-se tijolos. É possível observar presença de colonização biológica em todas as porções das ruínas.

Em algumas partes da construção há vestígios do piso original de ardósia, porém o mesmo já foi quase completamente saqueado. Em algumas colunas foram utilizados vários materiais, como blocos de rochas, tijolos, cimento e argamassa conchífera (Figura 7.f). Camadas posteriores de argamassa cimentada também podem ser observadas (Figura 7.g). Na área do salão principal é possível observar adornos decorativos, de figuras humanas e aleatórias, constituídas de cimento e expostas nas paredes (Figura 7.h).

A captação de água do engenho era feita aproveitando-se a água da serra (Figura 7.i), em um sistema de engenharia advindo com a colonização portuguesa. Em um dos tanques da captação de água, é possível observar a superfície do bloco de rocha polida (Figura 7.j), que constituía um local para polimento de ferramentas. 

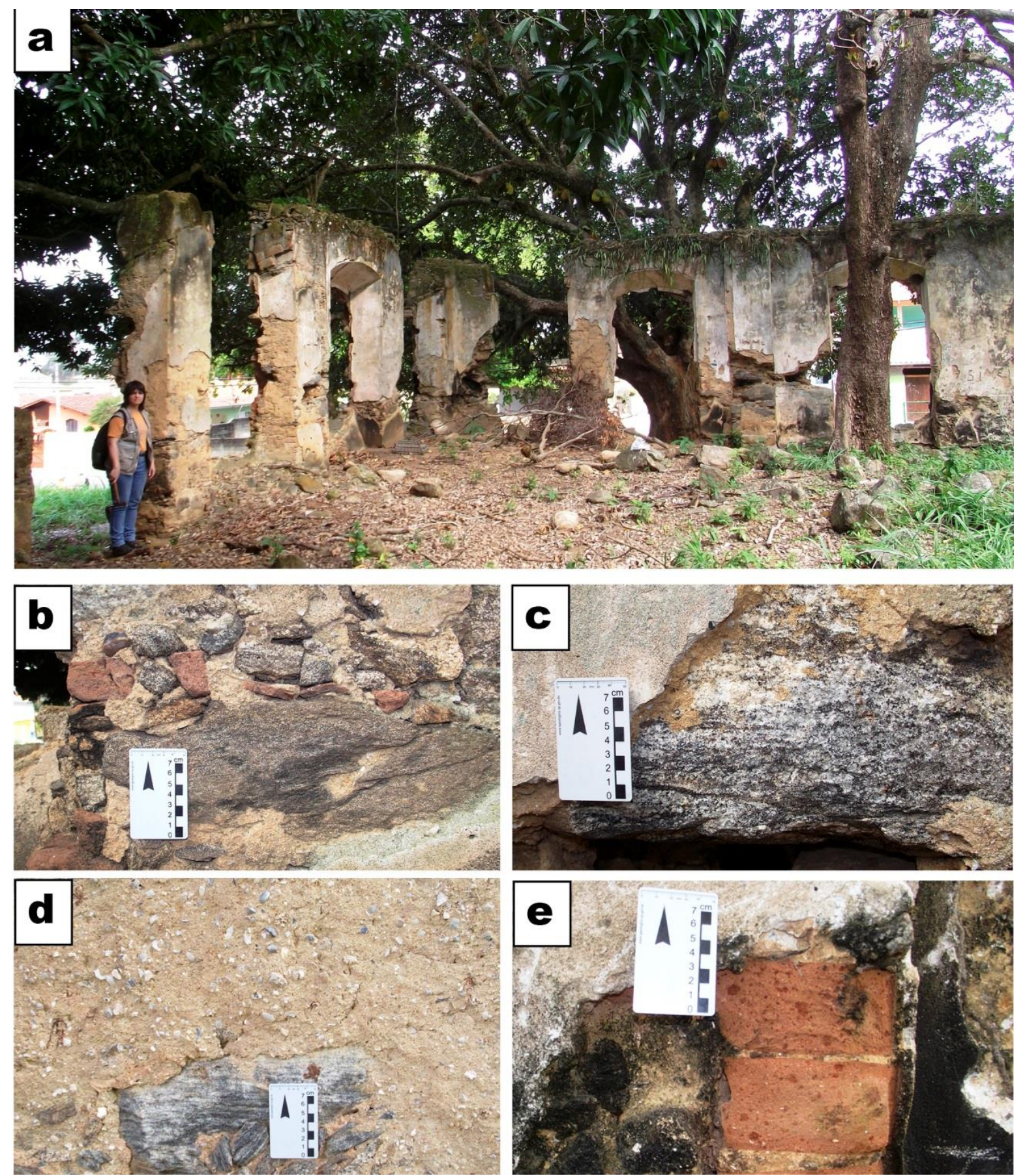

Figura 6. Sítio Histórico Morro do Abrigo. a - Ruínas do Sítio Morro do Abrigo; b - construção original da parede feita com rochas, tijolos e cal conchífera; c - detalhe no bloco de rocha gnáissica; $\mathrm{d}$ - detalhe em argamassa conchífera; e - intervenção posterior na contrução realizada com tijolos. 

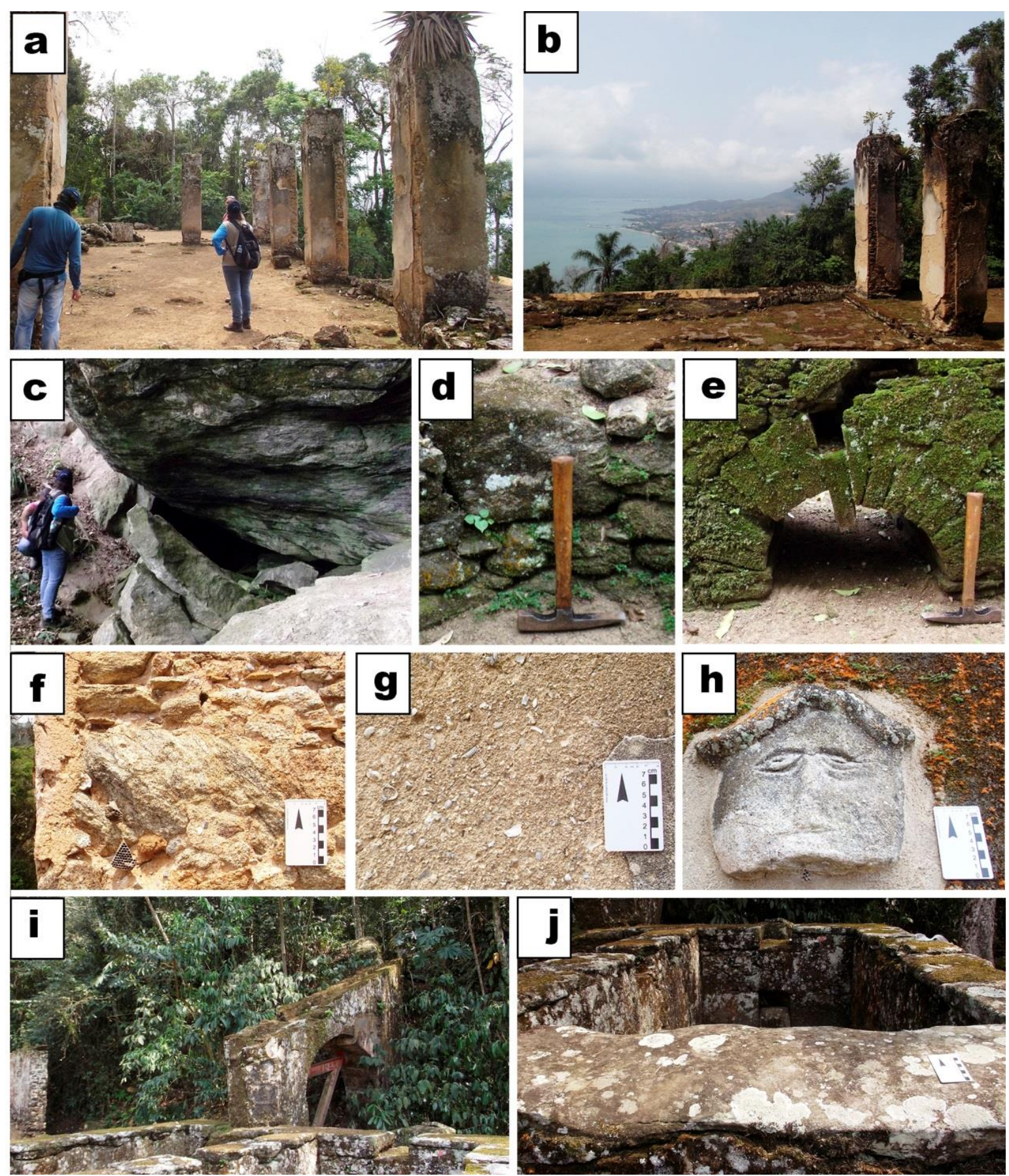

Figura 7. Sítio Histórico São Francisco. a - ruínas do Sítio São Francisco; b - visão fornecida a partir do sítio para São Sebastião; c - afloramento de gnaisse; d - blocos de gnaisse utilizados na construção; e - estrutura em arcadas feitas com blocos de rocha; $\mathrm{f}$ - colunas utilizando blocos de gnaisse; $\mathrm{g}$ - camadas de argamassa conchífera e de revestimento em cimento; $\mathrm{h}$ - adorno decorativo constituídas de cimento; $\mathrm{i}$ - sistema de captação de água da serra; j- porção do bloco rochoso polido, devido ao polimento de ferramentas.

\subsection{Ilhabela}

\section{Paróquia Nossa Senhora D’Ajuda}

A Paróquia Nossa Senhora D’Ajuda (Figura 8.a) é uma construção em pedra, tijolo e cal datada do século XVIII, localizada na Praça Prof. Alfredo Oliani 53 no centro de 
Ilhabela, com coordenadas 23K 463538/737019. Os dados a seguir apresentadossobre a história da paróquia foram obtidos dos folhetos informativos disponíveis na paróquia.

A história da construção da paróquia está associada aos primeiros moradores da Ilha de São Sebastião, que introduziram na cultura local uma forte devoção de origem portuguesa à Nossa Senhora D’Ajuda. Em 1697, o Padre Manoel Gomes Pereira mandou construir na ilha a primeira capela, mais tarde conhecida como Paróquia Nossa Senhora D’Ajuda. Com o passar do tempo, por falta de adequada conservação, a Paróquia foi se deteriorando e, por volta de 1793, foi realizada uma reforma por Matias José Bitencourt, que a reconstruiu quase que totalmente, seguida de outra reforma em 1800.

O estado atual da Paróquia Matriz de Ilhabela, como também é conhecida, é fruto do trabalho do escultor paulista Alfredo Oliani. A partir de 1950, este artista começou a arrecadar doações para a reforma da fachada, dos altares, da pintura do forro, dos quadros e colocação de novo piso.

Elementos geológicos presentes na construção original da paróquia representam a geodiversidade de Ilhabela e podem ser vistos nas pedras que constituem os muros da Paróquia. O muro frontal da paróquia é constituído por blocos de gnaisse granítico, de coloração cinza, às vezes rosado, e com algumas porções pegmatíticas (Figura 8.b). O muro lateral (Figura 8.c) é constituído por blocos de sienito, alguns apresentando auréola de alteração (Figura 8.d), e o piso é constituído por muscovita quartzito.

Uma gruta foi montada para a colocação de uma imagem de Nossa Senhora D’Ajuda. O altar sob a santa é constituído por um bloco de sienito com cerca de $2 \mathrm{~m}$ de diâmetro, assim como as paredes com blocos menores de sienito (Figura 8.e), rocha alcalina comum na Ilha.

A parede externa lateral da paróquia (Figura 8.f) tem sua construção original preservada e exposta, apresentando blocos de sienito, tijolos e concheiras (Figura 8.g). A proteção dessa parede é uma forma de manter conservado os registros históricos do período colonial no município.

$\mathrm{Na}$ área interna da paróquia tem-se a pia batismal, constituída de calcário fossilífero vermelho (Figura 8.h), e a escada do altar revestida de placas de mármore. No piso de entrada tem-se uma faixa de gnaisse, e todo o piso interno constitui um mosaico de rochas importadas com uma elevada diversidade litológica (Figura 8.i), adquiridas posteriormente para a reforma de 1950. Observam-se as seguintes rochas no piso: mármores de cores variadas - branco, cinza, rosa, esverdeado, amarelo ouro e preto, 
com dobras em algumas placas, além de travertino, Lioz, serpentinito e gnaisse vermelho bastante deformado.

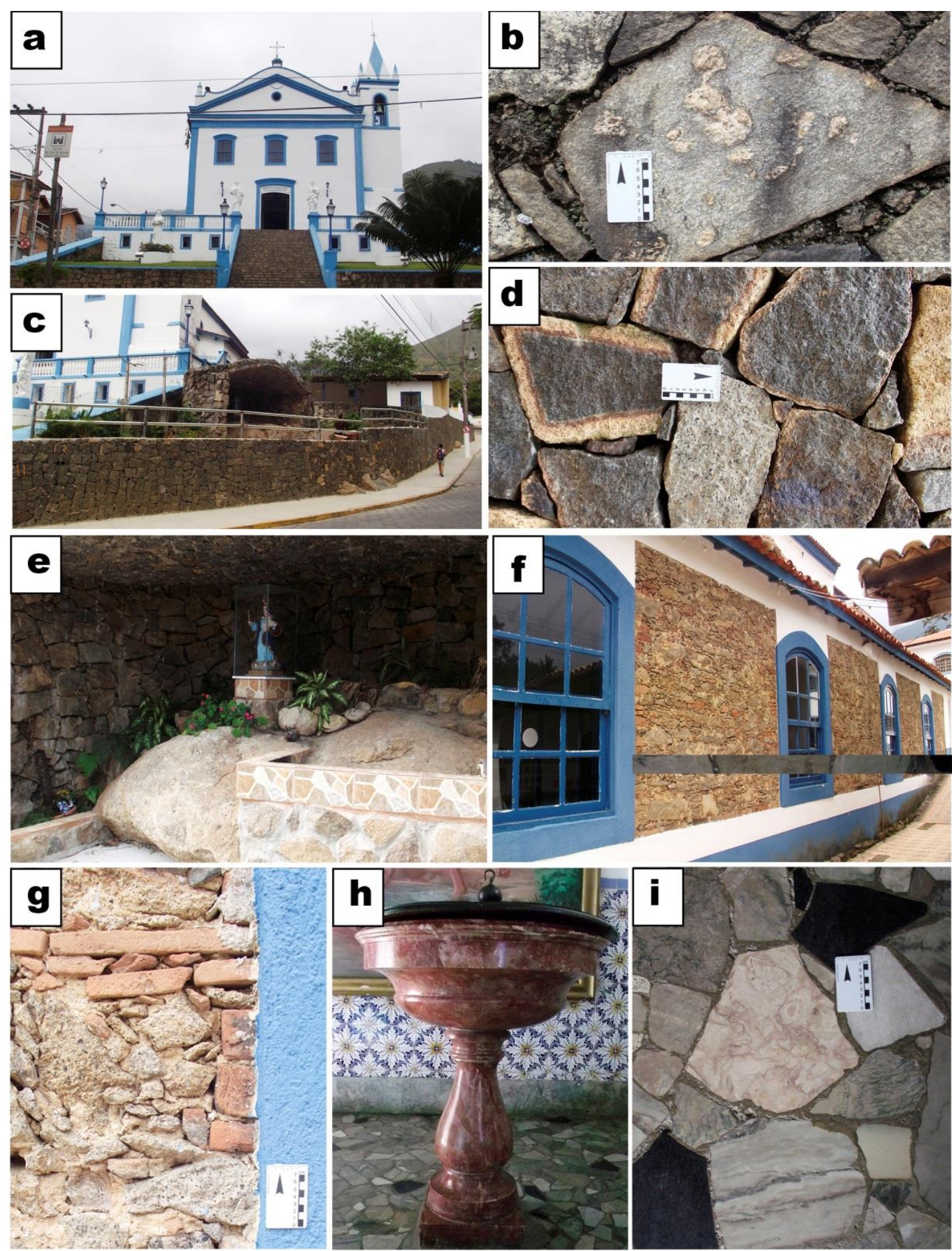

Figura 8. Paróquia Nossa Senhora D’Ajuda. a - fachada; b - blocos de granito gnáissico localizados no muro frontal da paróquia, com porções pegmatíticas; $\mathrm{c}$ - muro lateral constituído de blocos de sienito; d - detalhe nos blocos de sienito, alguns contendo auréola de alteração; e gruta da Nossa Senhora D'Ajuda, composta por blocos de sienito; $\mathrm{f}$ - parede externa lateral da paróquia, com o muro original preservado; $\mathrm{g}$ - muro lateral preservado composto por rochas, tijolos e argamassa conchífera; $\mathrm{h}$ - pia batismal constituída de calcário fossilífero; $\mathrm{i}$ - detalhe do piso interno, mosaico de calcários, mármores diversos e sienitos. 


\section{Antigo Mercado de Escravos}

O antigo mercado de escravos ficava situado em frente ao Canal de São Sebastião (Figura 9), na Praça Coronel Julião de Moura Negrão, centro histórico de Ilhabela, coordenadas 23K 463461/7370198, em local de fácil embarque e desembarque de mercadorias e de pessoas. Nesse período ainda não existiam pier ou atracadouros na vila, assim, mercadorias e pessoas eram desembarcadas diretamente na praia.
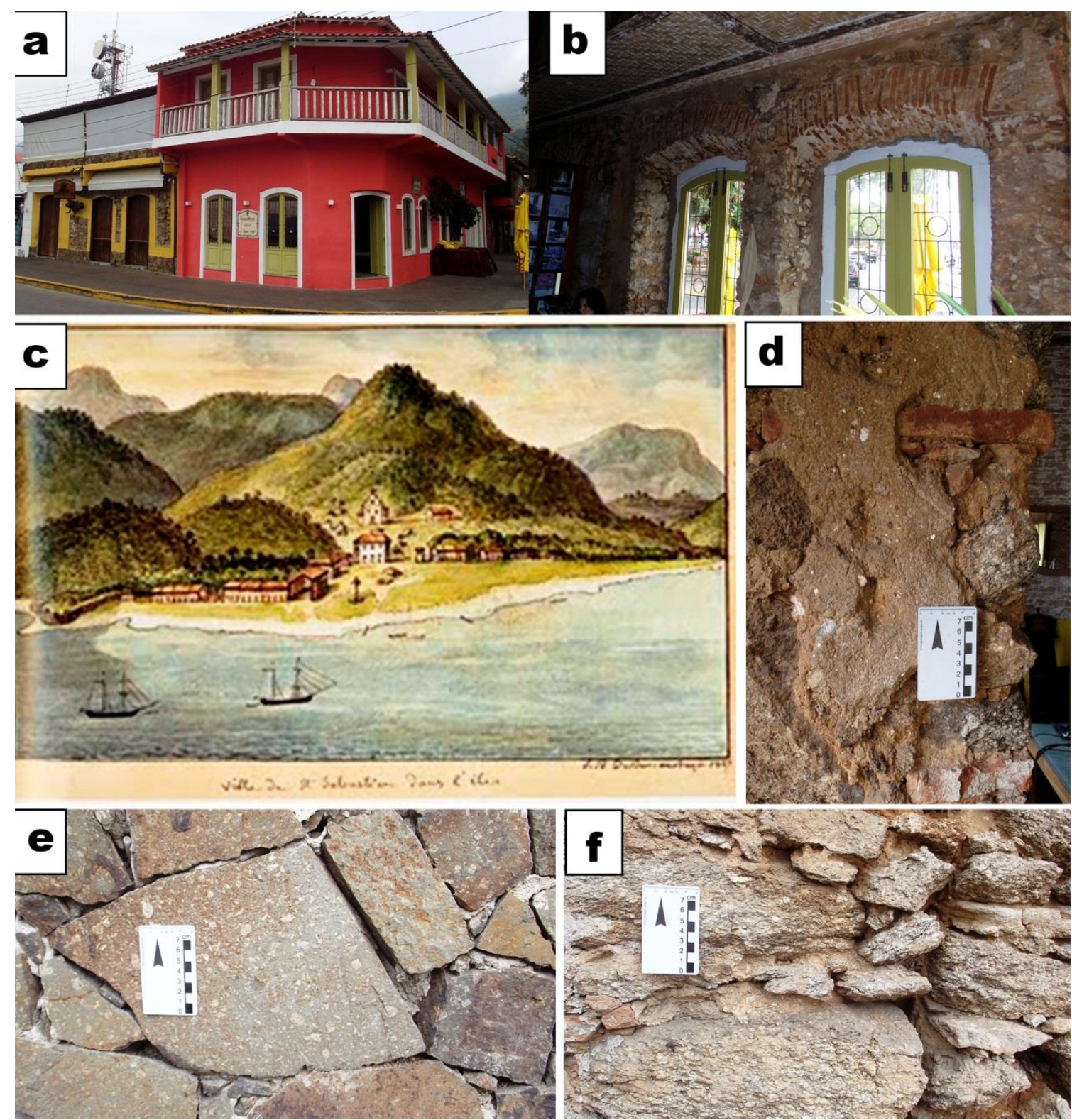

Figura 9. Antigo mercado de escravos de Ilhabela. a - configuração atual do antigo mercado de escravos, onde funciona um comércio; b - algumas áreas da construção permanecem preservadas; c - pintura de 1827 por Jean Baptiste Debret retratando a ilha; d - detalhe da parede original da construção preservada, contendo pedras, tijolos e argamassa conchífera; e blocos de rochas alcalinas porfiríticas; $\mathrm{f}$ - blocos de rochas sieniticas intemperizadas. 
Nesse mercado eram comercializados diversos produtos consumidos na vila, porém o comércio mais movimentado era o de escravos, onde eram selecionados e vendidos para as principais fazendas da região (Bendazzoli 2014).

O prédio é atualmente ocupado por uma imobiliária e uma lanchonete (Figura 9.a), mas algumas das suas feições originais ainda estão preservadas, como colunas em pedras, paredes e arcos de passagem na parte interna e externa da construção (Figura 9.b).

Uma pintura em aquarela feita em 1827 por Jean Baptiste Debret (Figura 9.c), durante uma viagem sua à ilha, retrata a vila onde atualmente é a cidade de Ilhabela, com a antiga Paróquia da matriz, o prédio da cadeia,o fórum e a área da atual praça Cel. Julião de Moura Negrão, onde se localizava este mercado de escravos e o pelourinho, até então desconhecidos (Bendazzoli 2014).

O comércio de escravos na ilha possibilitou a formação de quilombos na região de Villa Bella (antiga Ilhabela). O centro histórico de Ilhabela foi palco das principais decisões políticas e administrativas da primeira vila, assistiu à chegada de estrangeiros e à defesa contra os corsários, abrigando muitos canhões para defesa da costa.

$\mathrm{O}$ antigo mercado de escravos de Ilhabela foi construído usando-se blocos de rochas, tijolos nos arcos das janelas e cal conchífera (Figura 9.d). As rochas utilizadas são as mesmas encontradas na ilha, rochas vulcânicas alcalinas, algumas porfiríticas (Figura 9.e), e a maioria composta de sienito, já bastante intemperizado (Figura 9.f).

\subsection{Caraguatatuba}

\section{Paróquia Matriz Santo Antônio}

A Paróquia Matriz Santo Antônio, foi primeiramente construída como a Capela de Santo Antônio de Caraguatatuba, em meados do século XVII, com alvenaria de tijolo. Após passar por diversas reformas, acabou sendo reconstruída em 1857, sob a responsabilidade do Pe. Vigário Manuel Antônio da Silva, sendo posteriormente reconstruída várias vezes. A data oficial de sua fundação é considerada como sendo 12 de junho de 1840, por Dom Manuel Joaquim Gonçalvez de Andrade. Ela localiza-se na Praça Cândido Motta, centro de Caraguatatuba, nas coordenadas 23K 457954/7387545.

Segundo a Fundação Educacional e Cultural de Caraguatatuba - Fundacc, em 1948 a Paróquia passou pela sua primeira grande reforma. Neste período, estava sob a responsabilidade do Pároco Frei Pacífico Wagner. A partir daí, passou por outras 
reformas e ampliações até ganhar o aspecto que tem hoje. A Paróquia está incluída na rota turística Passos dos Jesuítas - Anchieta.

A Paróquia Matriz Santo Antônio, embora não tenha revestimento exterior de materiais pétreos, apresenta em seu interior grande variedade de pedras ornamentais, como no piso, nas colunas, nas paredes internas e em alguns objetos .

O piso de entrada que dá acesso à Paróquia é constituído por mármore na configuração de pedra portuguesa na área externa (Figuras 10.b), enquanto na área interna o piso é constituído de mosaico de granito cinza equigranular com granulação fina e granito vermelho inequigranular (Figura 10.c). O piso na área externa lateral da Paróquia é constituído por placas de ardósia. As paredes e colunas localizadas na entrada da Paróquia são revestidas até meia altura por leucogranito contendo cristais de granada (Figura 10.d), similar ao Granito Carlos Chagas (Pinto et al. 2001), com arremate de uma faixa em granito vermelho.

$\mathrm{Na}$ área interna é possível observar alguns objetos constituídos por elementos geológicos, como a pia batismal (Figura 10.e), constituída por mármore cinza escuro e com a porção superior (mais escura) polida, devido ao constante passar de mãos dos fiéis, uma mesa de apoio na entrada constituída por granito porfirítico com megacristais de feldspatos com tonalidade mais alaranjada (Figura 10.f), e o pedestal de Nossa Senhora é constituído por granito vermelho com granulação mais grossa com relação ao piso, sendo a mesma rocha usada no piso e degraus do altar.

De frente para o altar, ao lado esquerdo, tem-se um afloramento de gnaisse granítico milonítico com granulação grossa, bastante estirado, com cerca de $3 \mathrm{~m}$ de diâmetro (Figura 10.g), que foi preservado durante a ampliação da área da Paróquia. No afloramento é possível observar também a ocorrência de bandas de gnaisse de granulação mais fina, com presença de enclaves (Figura 10.h). Algumas intervenções foram realizadas na área do afloramento, como a instalação de rampa com piso constituído por blocos cimentados de gnaisses nas porções finais do afloramento.

É possível observar algumas características de deterioração das rochas na área interna da Paróquia, tais como eflorescência de sais na parede constituída por leucogranito (Figura 10.i) e presença de umidade (Figura 10.j). No piso interno, constituído por granito cinza, há manchamento associado à umidade ascendente, clareando algumas porções da rocha (Figura 10.k). 

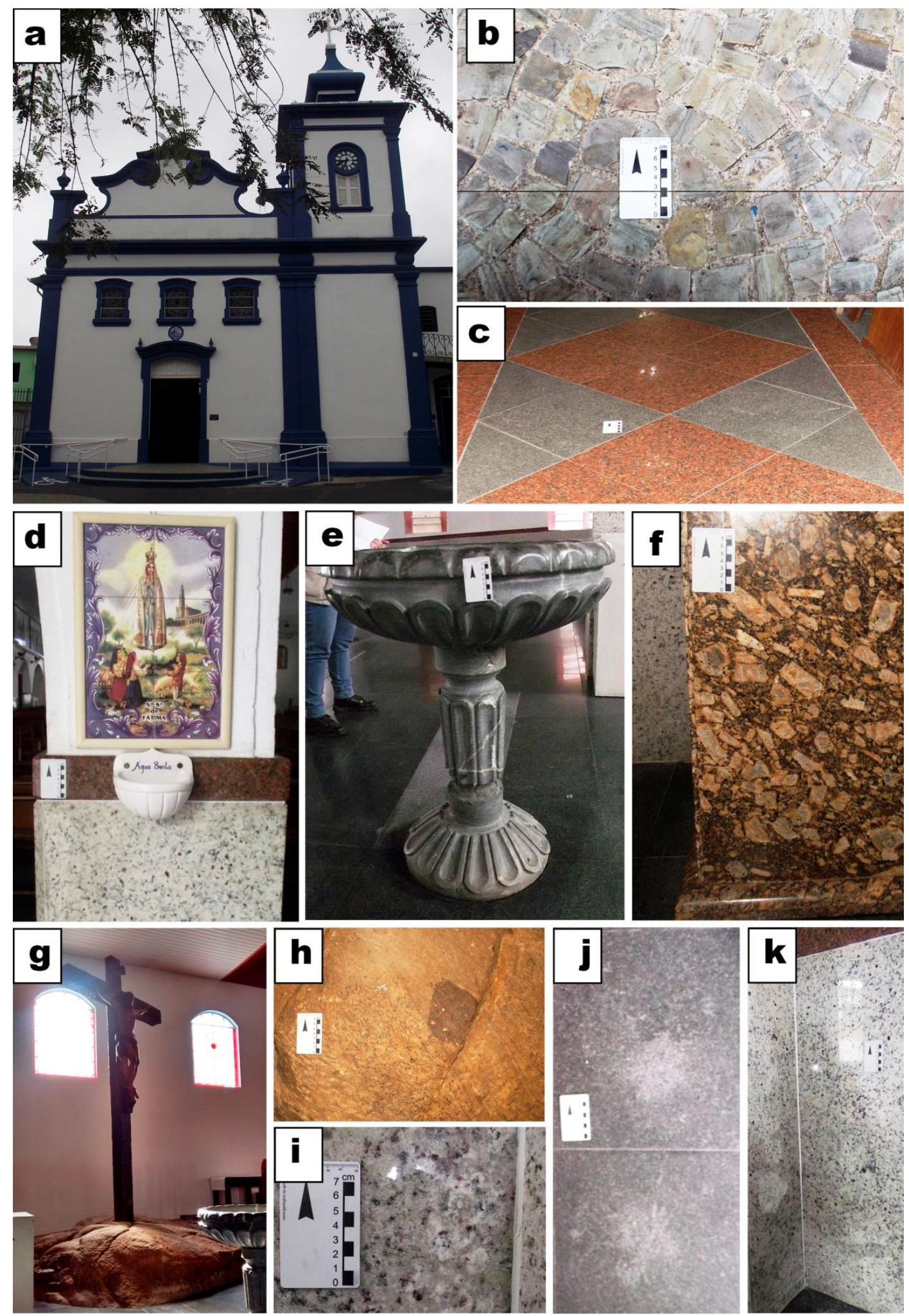

Figura 10. Paróquia Matriz Santo Antônio. $a$ - vista da fachada; $b$ - pedras portuguesas no piso de entrada; c - mosaico de rochas graníticas (cinza) e mármore (rosa) no piso interno; d coluna revestida por leucogranito com cristais de granada; e - pia batismal de mármore escuro, com porção superior apresentando aspecto brilhante; $\mathrm{f}$ - mesa de apoio constituída por granitos porfiríticos, com megacristais de feldspato; $\mathrm{g}$ - afloramento de gnaisse granítico milonítico na área do altar; $\mathrm{h}$ - enclave no gnaisse; $\mathrm{i}$ - paredes de granito apresentando eflorescência de sais; $\mathrm{j}$ - parede de granito apresentando sinais de umidade; $\mathrm{k}$ - piso de granito apresentando manchamento devido à umidade ascendente. 


\section{Relógio do Sol}

O Relógio do Sol, ou Monumento do $1^{\circ}$ Centenário (Figura 11.a), está localizado na Praça Cândido Mota, centro de Caraguatatuba, com coordenadas 23K 458044/7387544, próximo à Paróquia Santo Antônio e ao Museu de Arte e Cultura de Caraguatatuba, e possui cerca de $3,5 \mathrm{~m}$ de altura.

Foi construído em 1957, quando das comemorações do centenário da cidade. O monumento com base em pedra, representa o marco zero da cidade, e tem ilustrada uma vista oblíqua de Caraguatatuba (Figura 11.b), junto com os dizeres em latim Hohas non numero nisi serenas, que significa Só marco as horas serenas da vida (Figura 11.c).

O Relógio do Sol é protegido pela Lei Municipal de 13 de dezembro de 2006. Foi encomendado ao engenheiro Accacio Villalva a construção de um monumento que perpetuasse o sentimento do caraguatatubense naquele ano de comemoração do primeiro centenário de fundação da cidade.

O monumento possui a base composta por placas de granito oceolar cinza, com ocelos centimétricos (Figura 11.d) e os degraus compostos por gnaisse granítico milonítico bastante estirado (Figura 11.e). Como formas de alteração observadas, citamse a presença de sujidade, colonização biológica (Figura 11.f), concreção, aspecto brilhante (devido ao constante passar de mãos dos visitantes) (Figura 11.g), lacunas, além de algumas pequenas fraturas.

\subsection{Ubatuba}

\section{Ruínas da Lagoinha}

As Ruínas da Lagoinha são vestígios da antiga fazenda Bom Retiro (Figura 12.a), construída em 1828 com blocos de rochas, tijolos e argamassa conchífera, por um dos primeiros proprietários da Lagoinha, o engenheiro francês Stevenné, sendo classificada como engenho devido ao aqueduto existente e ao que restou das instalações de uma roda d'água (Fundart 2015a). Está localizada no bairro da Lagoinha nas coordenadas $23 \mathrm{~K}$ 479619/7400177, e com acesso pela rua Engenho Velho no km 73 da rodovia RioSantos.

As ruínas principais são constituídas por três paredões chegando à altura de aproximadamente $8 \mathrm{~m}$, constituídos por blocos rochosos de diversos tamanhos, apresentando arcadas com grandes janelas. Na lateral das ruínas principais está o muro que conduz o aqueduto, contendo arcadas constituídas por tijolos. Foram tombadas pelo 


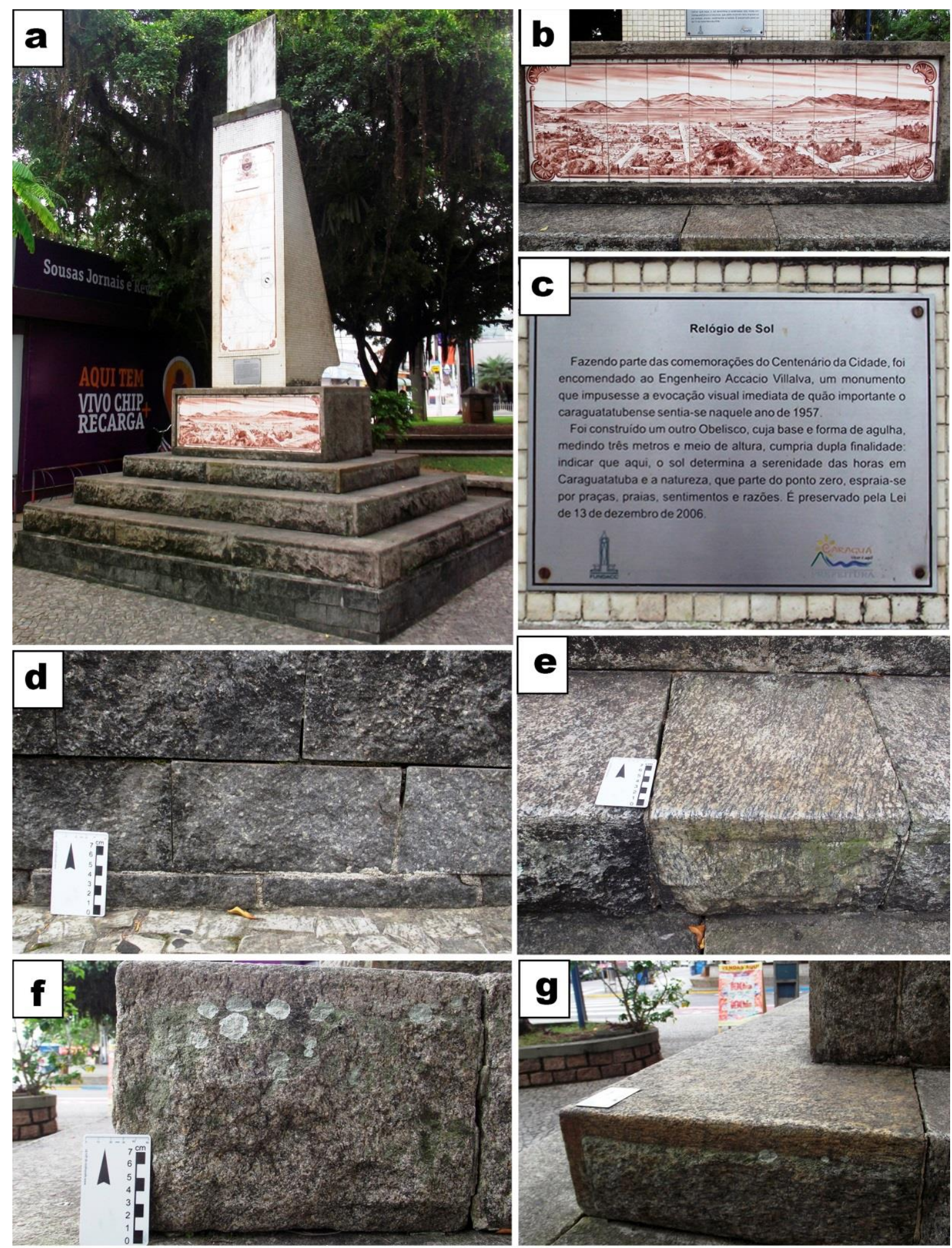

Figura 11. Monumento do Relógio do Sol ou do $1^{\circ}$ Centenário. a - Relógio do Sol; b - vista oblíqua da cidade de Caraguatatuba; c - placa em aço simbolizando o $1^{\circ}$ Centenário da cidade de Caraguatatuba; d - base do monumento em granito ocelar; e - degraus do monumento constituído por placas de gnaisse granítico milonítico; $\mathrm{f}$ - presença de colonização biológica; $\mathrm{g}$ aspecto brilhante no gnaisse. 
Condephaat - Conselho de Defesa do Patrimônio Histórico, Arqueológico, Artístico e Turístico do Estado de São Paulo em 1985, com o objetivo de proteger e valorizar o patrimônio histórico do município.

Em 1989 o patrimônio histórico passou a ser administrado e mantido pela Fundart. O local é aberto para visitações e representa a história do município, sendo testemunha do período próspero em Ubatuba, quando em seu porto era negociada e exportada a produção do Vale do Paraíba. O local foi também cenário para filmes e ensaios fotográficos. As instalações originais das Ruínas da Lagoinha foram construídas principalmente por blocos heterogêneos de rochas de diversos tamanhos e composições litológicas (Figura 12.b), com grande quantidade de charnockito (Figura 12.c), comum na região de Ubatuba e conhecido como Granito Verde Ubatuba, blocos de granito porfíritico com cristais de feldspato se destacando na rocha (Figura 12.d) e blocos de rocha gnáissica (Figura 12.e). Em algumas porções é possível observar restos de argamassa de cal contendo grande quantidade de conchas, e tijolos constituindo algumas arcadas (Figura 12.f).

Atualmente, as ruínas encontram-se dominadas pela vegetação, contendo desde colonização biológica representada por fungos e musgos até arbustos, plantas epífitas e parasitas (Figura 12.g) e raízes de árvores de grande porte (Figura 12.h).

\section{Ruínas do Ipiranguinha}

As Ruínas do Ipiranguinha estão localizadas nas escarpas da Serra do Mar em Ubatuba (Figura 13.a), nas coordenadas 23K 486433/7409066. O acesso é feito pelo bairro do Ipiranguinha, pela rodovia Oswaldo Cruz no $\mathrm{km} \mathrm{89}$, ou pela Cachoeira do Ipiranguinha (ou da Escada) (Figura 13.b). O bairro do Ipiranguinha, onde estão localizadas as ruínas, servia de acesso ao Vale do Paraíba, sendo uma rota comum até meados do século XIX, em que as tropas de mulas carregadas levava e trazia pela serra os produtos de negócios e de troca.

Essas ruínas são vestígios de uma construção em pedra, datada do século XVII, que formava uma fazenda com grande variedade de produtos e servia também para estocagem e armazenamento de material de escambo que vinham do Vale, permanecendo em atividade até o início do século XX. A fazenda do Sítio do Engenho, hoje, bairro do Ipiranguinha, representa um passado de fartura e riqueza nessa região.

A antiga fazenda do Sítio do Engenho, da qual hoje somente restam as ruínas, é prova inabalável de uma época de solidez econômica, tendo em vista que a arquitetura 
implantada em Ubatuba deu-se quase que totalmente em confecção de madeira e taipa, e a referida fazenda, a caráter das grandes e sólidas edificações, fora totalmente confeccionada em pedra.

Atualmente nas proximidades das ruínas funciona um bar (Figura 13.c) que atrai visitantes pela presença da Cachoeira do Ipiranguinha. Para se chegar até as ruínas deve-se seguir a trilha atrás do bar e caminhar por volta de $250 \mathrm{~m}$ (Figura 13.d), passando por alguns afloramentos de gnaisse com foliação milonítica (Figura 13.e). As ruínas são constituídas por muros de blocos de rochas gnáissicas e sem argamassa que foi, provavelmente, inteiramente lixiviada. As ruínas estão completamente envolvidas pela vegetação (Figura 13.f).

\section{Sobradão do Porto}

O Sobradão do Porto foi construído em 1846 (Figura 14.a) com utilização de alvenaria de pedra e argamassa, e pertencia a uma família tradicional da região. O prédio, composto por dois andares, era de uma arquitetura inovadora. Localiza-se nas coordenadas 23K 492550/7408714, na Praça Anchieta, centro de Ubatuba.

O primeiro pavimento servia como um armazém, onde se guardavam e negociavam toda a mercadoria de sacas de café, algodão, fumo, cana-de-açúcar e aguardente, tanto produzida em Ubatuba como em toda região do Vale do Paraíba. O segundo andar era utilizado como residência.

Com a decadência econômica de Ubatuba pelo fechamento de seu porto, muitos casarões foram abandonados, porém o Sobradão do Porto manteve-se soberano e, em 1926, passou a abrigar o Hotel e Restaurante Budapest (Fundart 2015b).

Em 1959 foi tombado pela Secretaria do Patrimônio Histórico, Arqueológico e Arquitetônico Nacional - Sphaan. Mais tarde, o valor histórico e arquitetônico do Sobradão do Porto também foi reconhecido, com o seu tombamento pelo Conselho de Defesa do Patrimônio Histórico, Arquitetônico, Artístico e Turístico do Estado de São Paulo - Condephaat. Em 1981, o Sobradão foi desapropriado pela Prefeitura Municipal e, em 1987, tornou-se a sede administrativa da Fundação de Arte e Cultura de Ubatuba - Fundart. Na década de 80, foram realizados trabalhos de restauro da parte estrutural do prédio, com verbas do Ministério da Cultura sob a supervisão do Sphaan, de São Paulo. O contato com o Iphan - Instituto do Patrimônio Histórico e Artístico Nacional foi retomado em 2001, para a assessoria técnica especializada visando serviços emergenciais de conservação. 

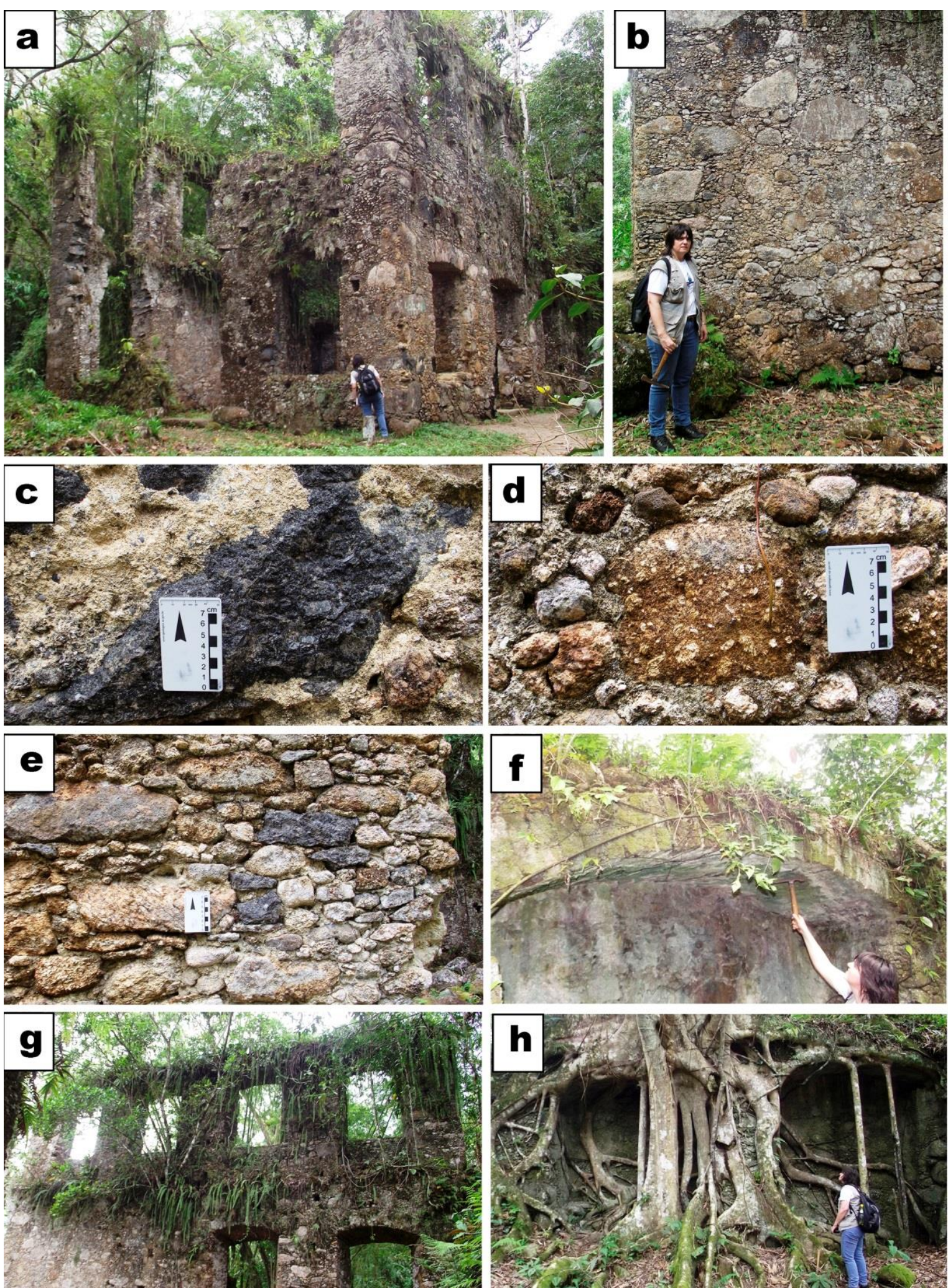

Figura 12. Ruínas da Lagoinha, Ubatuba. a - Visão geral; b - paredes constituídas por blocos heterogêneos de rocha; $\mathrm{c}$ - bloco de rocha charnockítica contendo áreas com revestimento em argamassa conchífera; $\mathrm{d}$ - bloco de granito porfirítico; e - bloco de rocha gnáissica; f - arcada constituída de tijolos; g - vegeteção recobrindo as ruínas; h - raízes de árvores de grande porte já estruturadas sobre as ruínas. 

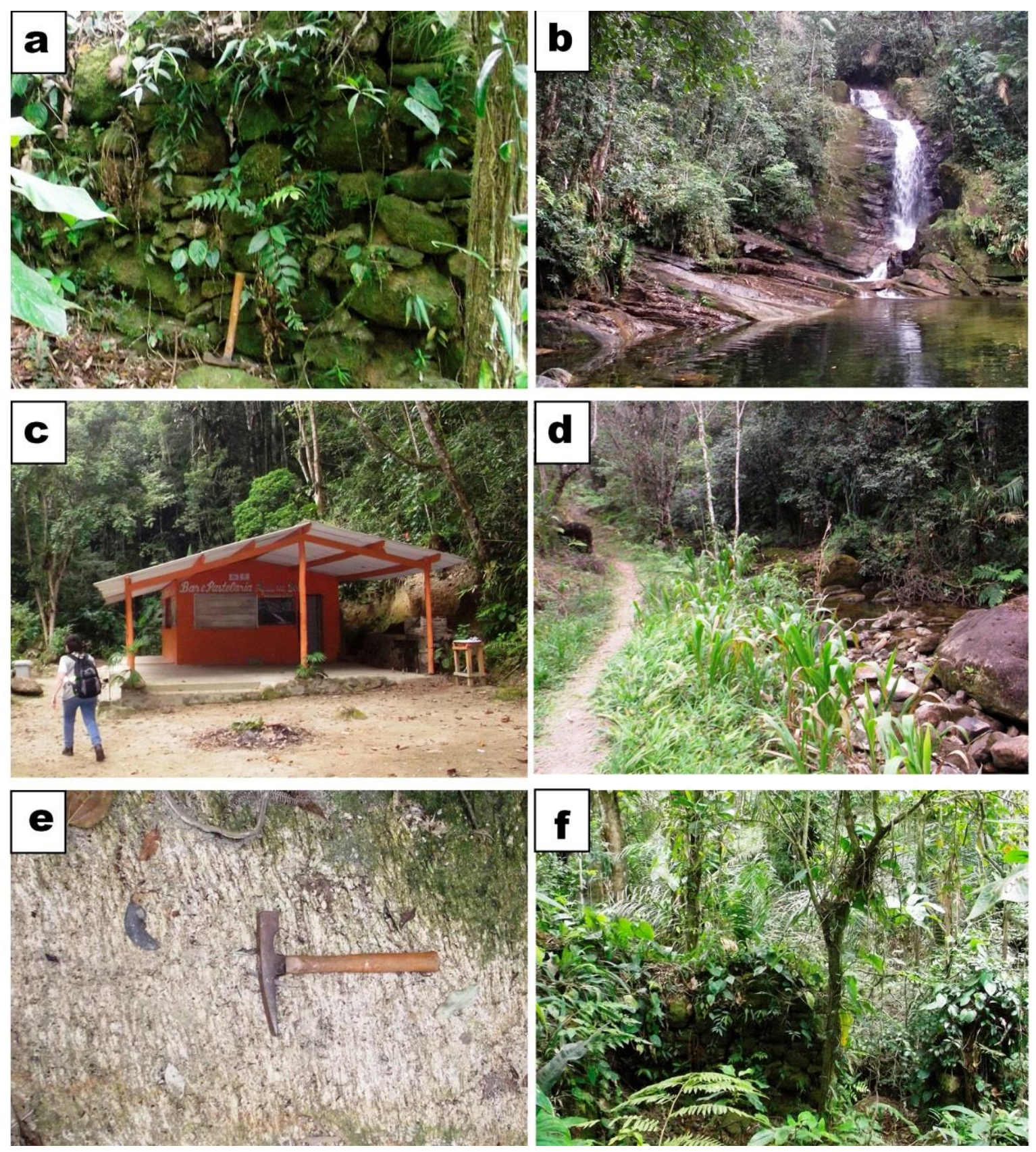

Figura 13. Ruínas do Ipiranguinha. a - muro das Ruínas do Ipiranguinha; b - cachoeira do Ipiranguinha ou da Escada; c - bar localizado no início da trilha que leva às ruínas; $d$ - trilha de $250 \mathrm{~m}$ até as ruínas; $\mathrm{e}$ - afloramento de gnáissica milonítico na trilha; $\mathrm{f}$ - estado atual das ruínas tomada pela vegetação.

A administração da Fundart desocupou as dependências do andar superior do Sobradão em 2005, devido ao precário estado de sua estrutura. Em 2007 o contato com o Iphan resultou na elaboração de um projeto de restauro, projeto aprovado em 2009, iniciando-se a fase de captação de recursos para a sua execução

Na construção do Sobradão do Porto foram utilizados tijolos, pedras e argamassa. As pedras estão localizadas na parte externa da casa e nas fachadas das nove portas (Figura 14.b). 
A rocha utilizada na confecção das fachadas das portas é um granada-biotita gnaisse facoidal, com granadas centimétricas (Figura 14.c), uma rocha ortoderivada bastante resistente ao intemperismo e que foi usado na construção de grande parte dos monumentos históricos da cidade do Rio de Janeiro, na forma de ornamentos, fachadas e molduras de portas e janelas. O uso dessa rocha no Sobradão do Porto pode estar relacionado com sua proximidade ao estado do Rio de Janeiro, de onde ela foi importada.

O uso do gnaisse facoidal na cantaria foi descrito por Jean Baptiste Debret em seu livro Viagem Pitoresca e Histórica ao Brasil, onde explica que ele é mais macio, menos caro e facilmente explorável, destinando-se às partes dos edifícios que deveriam ser esculpidas (Mansur et al. 2008).

O plano de foliação dos gnaisses nas colunas está na vertical (Figura14.d), e na parte superior das portas está na horizontal, o que facilita o desplacamento da rocha pela erosão. Algumas arcadas apresentam rejunte de cimento revestindo uma porção da rocha.

É possível observar presença de fraturas (Figura 14.e) na rocha, erosão segundo os planos de foliação do gnaisse e colonização biológica e sujidade em toda a construção (Figura 14.f).

No topo do edifício há também dois vasos de cerâmica portuguesa (Figura 14.g). Defronte ao Sobradão há algumas informações sobre este colocadas em placas constituídas pelo Granito Verde Ubatuba (Figura 14.h).

O Sobradão do Porto representa o passado de prosperidade e glória de uma cidade que já abrigou o porto mais importante do país, sendo o único casarão que restou dos áureos tempos do café na segunda metade do século XIX em Ubatuba. Aberto à visitação, oferece espaço para exposições de arte, artesanato, fotografia, além de oficinas culturais, cursos e concursos que incentivam a produção artística, o resgate e valorização da cultura caiçara e suas tradições. É reconhecido como o principal patrimônio histórico de Ubatuba.

\section{Monumento em Homenagem ao Caiçara}

O Monumento ao Caiçara é representado por uma estátua de $10 \mathrm{~m}$ de altura, constituída de concreto sobre um pedestal revestido de rocha charnockítica, localizado em um trevo da rodovia BR-101 na entrada na cidade de Ubatuba (Figura 15.a), nas coordenadas 23K 491236/7408440. 


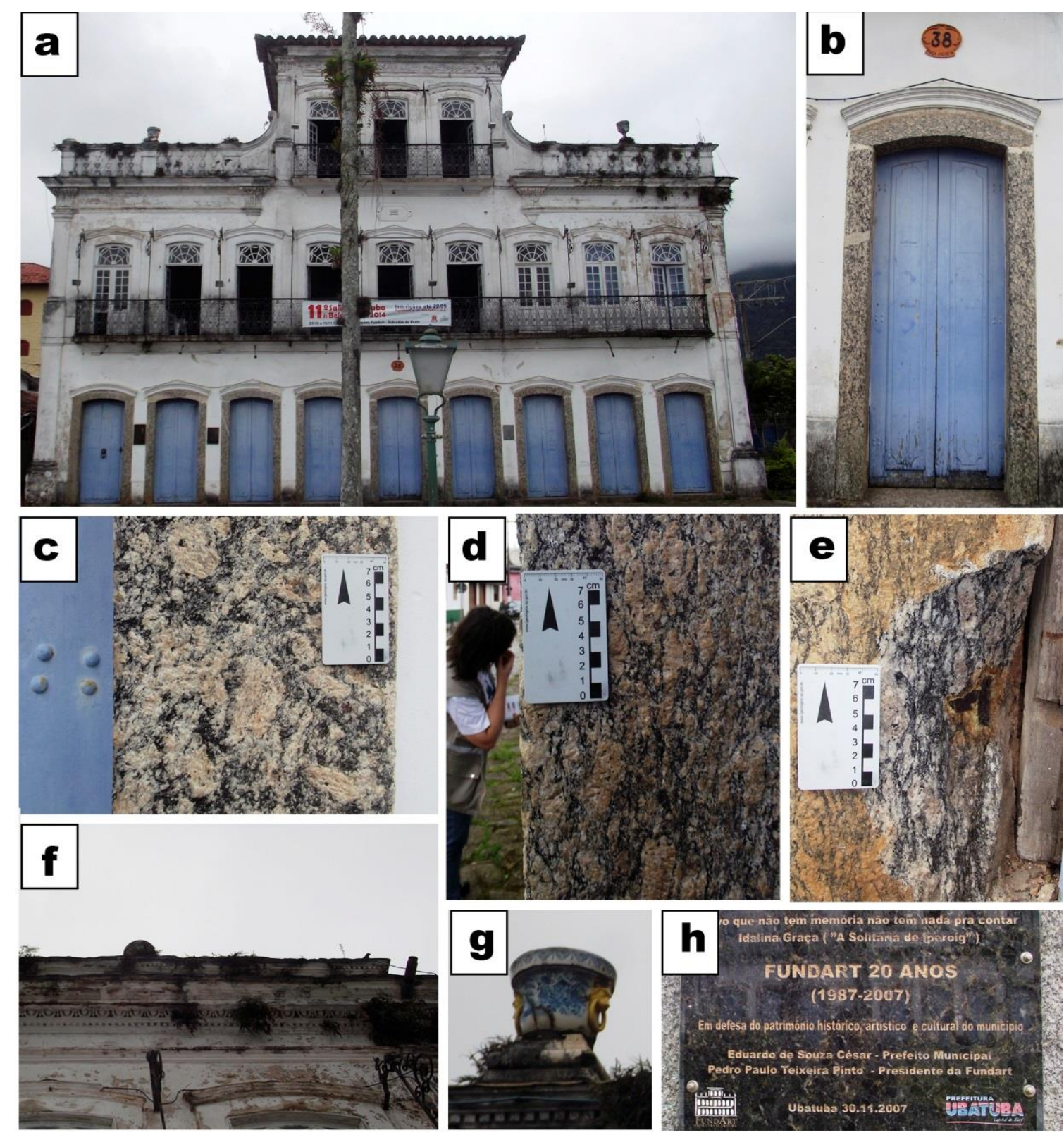

Figura 14. Sobradão do Porto, Ubatuba. a - vista geral; b - batente das portas constituídas por gnaisse facoidal, às vezes com rejunte de cimento recobrindo parte da rocha; c - detalhe do gnaisse facoidal rico em granada; $d$ - foliação vertical do gnaisse facoidal nas colunas das fachadas; e - coluna da fachada com perda de material; f - colonização biológica e sujidade presentes no edifício; g -vaso de cerâmica portuguesa ornamentando o topo do edifício; $\mathrm{h}$ placas informativas constituídas de rochas charnockíticas.

A estátua resgata a tradição dos caiçaras, antigos moradores do litoral paulista, representada pela figura de um pescador, sendo doada à comunidade em 2003, no aniversário de 366 anos de Ubatuba.

A base do monumento é constituída por placas de rocha charnockítica porfirítica (Figura 15.b), exibindo coloração verde escura típica da rocha, conhecida comercialmente como Granito Verde Ubatuba (Figura 15.c). Esta rocha é classificada como um ortopiroxênio-hornblenda monzogranito, e teve sua origem descrita em Freitas 
(1976) e Garda (1995) como magmática, datada em aproximadamente 565 Ma, como produto da fusão parcial das rochas de alto grau da crosta. Azevedo Sobrinho et al. (2011) associaram esta rocha à última gênese de granito no leste do estado de São Paulo.

Esta rocha ornamental é típica de Ubatuba e foi muito utilizada em monumentos e fachadas na região e também na cidade de São Paulo, como o pedestal da estátua de bronze de José Bonifácio na Praça do Patriarca, e em fachadas de alguns edifícios localizados no centro velho da cidade (Rodrigues 2012, Del Lama et al. 2015). Atualmente, a extração do charnockito de Ubatuba está proibida pelo fato de suas jazidas estarem dentro de uma área de preservação ambiental.

\section{Antiga Pedreira de Itamambuca}

A antiga pedreira de Itamambuca constitui-se em um dos locais de extração de charnockito, conhecido como Granito Verde Ubatuba, localizada na Praia de Itamambuca (Figura 16.a), nas coordenadas 23K 500694/741256, e o seu acesso dá-se pelo km 36 da rodovia Rio-Santos.

Este ponto foi descrito em Santos (2014) e definido como um geossítio de Ubatuba, pela importância que a rocha charnockítica possui na história e no desenvolvimento econômico e social no município de Ubatuba, além de representar importantes eventos da fase de aglutinação do Supercontinente Gondwana durante o Ciclo Brasiliano II (Hasui 2010).

Os charnockitos extraídos em Ubatuba chegaram a ser exportados para a Europa e Ásia. Segundo Santos (2014), existem pelo menos outros 160 pontos de antigas extrações de charnockitos, dentre as quais está a Pedreira Itamambuca, que representa uma das maiores áreas de extração da rocha. Com a criação do Parque Estadual da Serra do Mar em 1977, a extração da rocha foi proibida por estar inserida dentro da área de proteção ambiental. A interrupção da extração do charnockito gerou diversos problemas econômicos e sociais no município.

$\mathrm{Na}$ Praia de Itamambuca pode-se observar os remanescentes da antiga pedreira possuindo alguns blocos (Figura 16.b) com marcas de explosivos (Figura 16.c) utilizados na extração. Afloramentos e matacões de charnockito são encontrados nas áreas de extração da antiga pedreira no bairro Sertãozinho do Prumirim, além de um painel instalado no local contendo informações sobre o Granito Verde Ubatuba (Figura 16.d). 


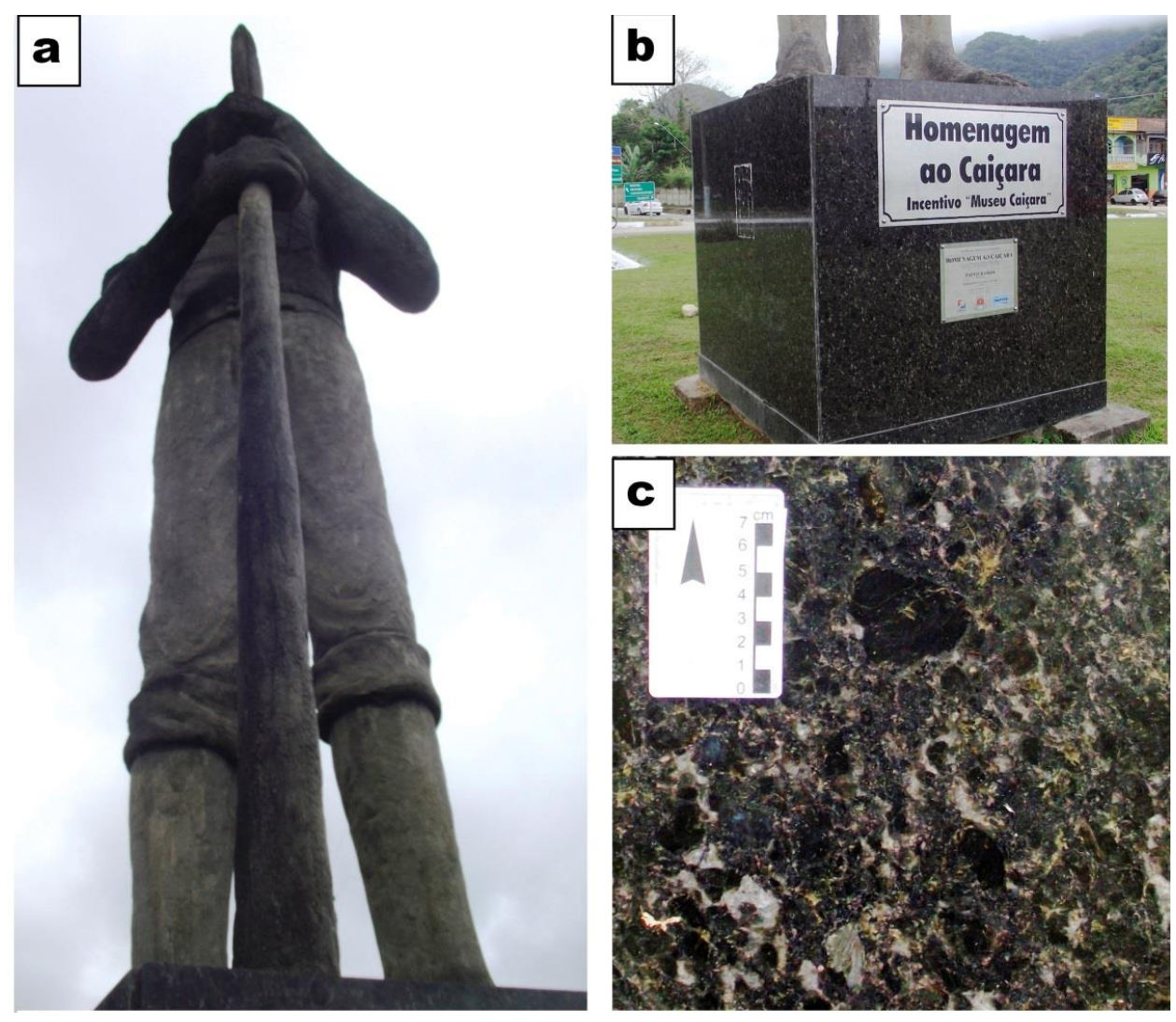

Figura 15. Monumento ao Caiçara, Ubatuba. a - estátua de concreto de $10 \mathrm{~m}$ de altura; $\mathrm{b}$ - base da estátua revestida por rocha charnockítica; $\mathrm{c}$ - detalhe do charnockito.
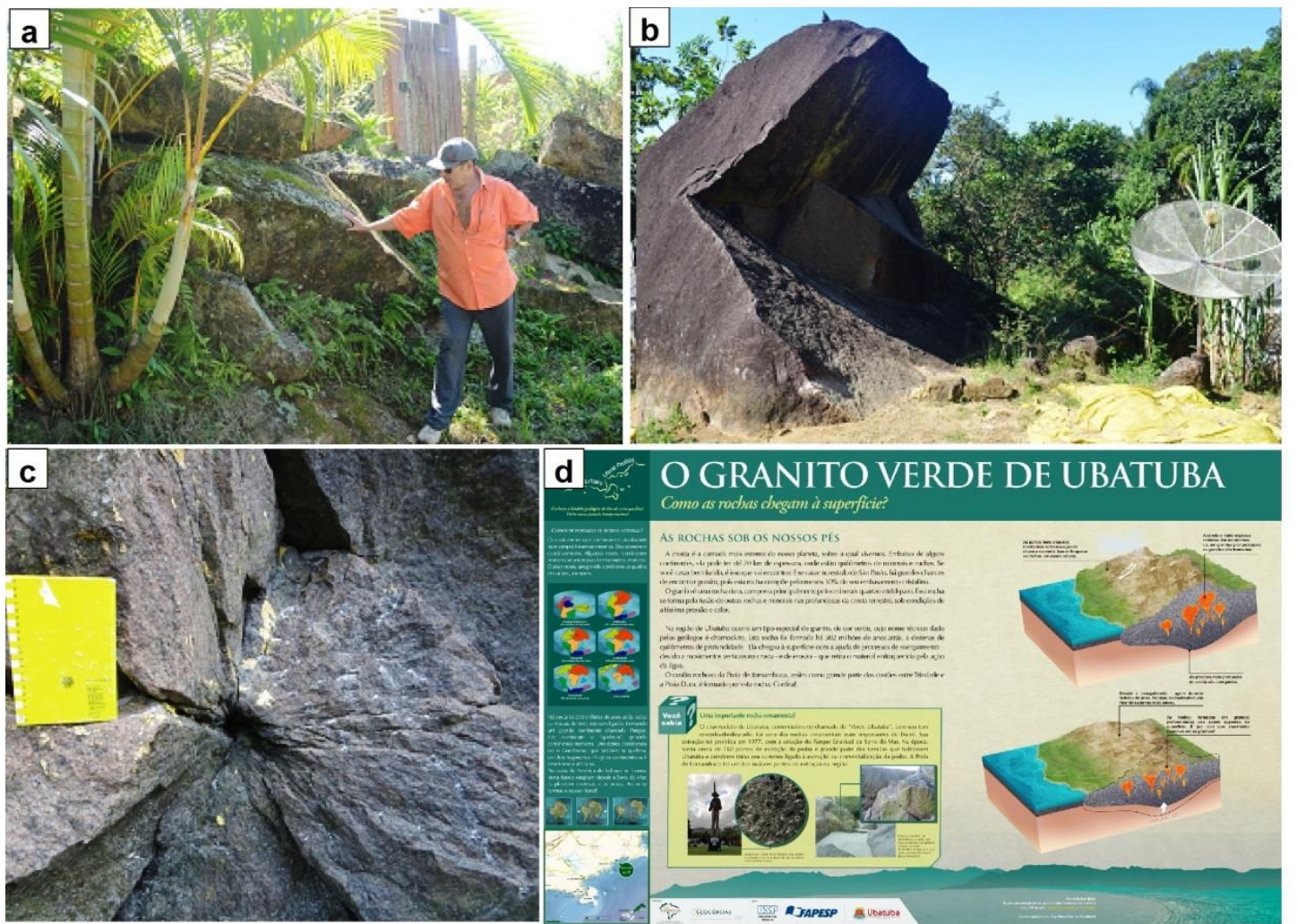

Figura 16. Antiga Pedreira de Itamambuca. a - ruínas da antiga pedreira localizada na Praia de Itamambuca; $\mathrm{b}$ - blocos de charnockito apresentando exploração do período da mineração; c marcas de explosivos nas rochas; $\mathrm{d}$ - painel instalado na antiga pedreira contendo informações sobre o Granito Verde Ubatuba. 


\section{Considerações Finais}

Com base no levantamento dos materiais pétreos utilizados nas construções e monumentos do patrimônio construído do litoral norte do estado de São Paulo, pode-se concluir que as rochas utilizadas foram obtidas principalmente das rochas existentes na região ou exclusivas do próprio município, como é o caso de Ilhabela, com sienito; Ubatuba, com charnockito; São Sebastião, com gnaisse migmatítico; e Caraguatatuba, com gnaisse granítico milonítico. A utilização dessas rochas nestes municípios está relacionada com os tipos litológicos predominantes no Domínio Costeiro (Heilbron et al. 2004), composto principalmente por ortognaisses e gnaisses metapelíticos parcialmente migmatizados, sendo todo o conjunto cortado por inúmeros corpos de composição granítica sin a tardi-colisionais (Campanha \& Ens 1996).

A importância de um inventário do material pétreo utilizado em construções antigas e históricas vai além do valor geológico, sendo um valioso dado para a compreensão do registro histórico e cultural de um povo, representando não só os litotipos disponíveis, mas também o momento socioeconômico de uma população. A utilização de pedras locais sem polimento e alvenaria é vista nas construções mais antigas, como no Sítio Histórico de São Francisco e Paróquia Nossa Senhora D’Ajuda, que representam construções do período colonial. Com o desenvolvimento da região, as construções e reformas foram realizadas utilizando-se pedras ornamentais importadas, europeia e de outros estados do Brasil, representando uma era de crescimento socioeconômico da região. Monumentos mais recentes, como o Monumento ao Caiçara, utilizam pedras ornamentais locais, valorizando os elementos geológicos da região. Tal valorização demonstra o desenvolvimento cultural associado ao reconhecimento de uma população acerca do seu valor histórico e econômico.

O presente inventário comporá, juntamente com patrimônio geológico e o patrimônio cultural, uma proposta futura de rota geoturística na região do litoral norte do estado de São Paulo. A utilização deste patrimônio como forma de divulgação geocientífica mostra-se de grande eficiência para abranger a parte da população que não pode ou não possui o hábito de visitar parques e áreas naturais, estando a maior parte do tempo no meio urbano sem contato direto com a natureza.

A utilização de informações litológicas do patrimônio construído é uma forma de diversificar e aprimorar o turismo já existente, além de subsidiar o uso didático voltado para a educação em geociências, já que o patrimônio histórico e cultural já é abordado 
em algumas escolas, e informações litológicas sobre esse patrimônio podem ser acrescentadas. A divulgação geocientífica auxilia no desenvolvimento cultural e pode trazer benefícios econômicos para uma região, valorizando o trabalho de guias de turismo com conhecimento sobre geociências, por exemplo, e levando mais turistas e curiosos do centro urbano para o meio natural, visto que, com a informação geológica recebida, eles podem ser induzidos a quererem conhecer outros lugares que tenham a geodiversidade como um fator de interesse principal. O próprio conhecimento geológico, mesmo que não aprofundado, e a própria informação histórico-cultural pode favorecer e incentivar ações de geoconservação, tanto do patrimônio construído quanto do natural, pois só se conserva aquilo que se conhece.

\section{Referências}

AIRES-BARROS L. 1991. Alteração e alterabilidade de rochas. Universidade Técnica de Lisboa, Instituto Nacional de Investigação Científica, Lisboa, 384p.

ALMEIDA F.F.M. 1969. Diferenciação tectônica da plataforma Brasileira. In: Congresso Brasileiro de Geologia, 23, Salvador, 1969. Anais, p. 29-46.

ALMEIDA F.F.M., HASUI Y., BRITO NEVES B.B., FUCK R.A. 1977. As províncias estruturais brasileiras. In: VIII Simpósio de Geologia do Nordeste, Campina Grande, PB, Atas, p.363-391.

ARRUDA K.E.C., GARCIA M.G.M., DEL LAMA E.A. 2015. Geological Heritage Inventory as a Subsidy for Geotourism: Caraguatatuba - São Paulo State, Brazil. In: The VIII International ProGEO Symposium, 2015, Reykjavik, Iceland. The VIII International ProGEO Symposium, 2015.

AUGUSTO W.C.B., DEL LAMA E.A. 2011. Roteiro geoturístico no centro da cidade de São Paulo. Terrae Didatica 7:29-40.

AZEVEDO SOBRINHO J.M., JANASI V.A., SIMONETTI A., HEAMAN L.M., SANTORO J., DINIZ H.N. 2011. The Ilha Anchieta Quartz Monzonite: the southernmost expression of $\mathrm{Ca} .500 \mathrm{Ma}$ post-collisional magmatism in the Ribeira Belt. Anais da Academia Brasileira de Ciências, 83(3): 891-906.

BENDAZZOLI C. 2014. O Antigo Mercado de Escravos de Villa Bella da Princesa. Disponível em: <http://ilhabelaarqueologica.blogspot.com.br/2014/01/o-antigomercado-de-escravos-de-villa.html > acessado em maio de 2015.

BORNAL W.G. 2008. Sítio Histórico São Francisco. Um estudo sob a ótica da Arqueologia da Paisagem. Tese de Doutorado, São Paulo: FFLCH/USP. 297p. 
BRILHA J. 2016. Inventory and Quantitative Assessment of Geosites and Geodiversity Sites: a Review. Geoheritage 8:119-134.

CAMPANHA G.A.C., ENS H.H. 1996. Estruturação geológica da região da Serra do Juqueriquerê, São Sebastião, SP. Boletim IGc-USP 27:41-49.

CARVALHO H.L. 2010. Patrimônio geológico do centro histórico de Natal. Monografia (Graduação), Centro de Ciências Exatas e da Terra, Universidade Federal do Rio Grande do Norte. 105p.

CRUZ O. 1990. Contribuição geomorfológica ao estudo de escarpas da Serra do Mar. Revista do Instituto Geológico, 11(1):9-20.

DEL LAMA E.A., DEHIRA L.K., REYS A.C. 2009. Visão geológica dos monumentos da cidade de São Paulo. Revista Brasileira de Geociências. 39(3):409-420.

DEL LAMA E.A., BACCI D.C., MARTINS, L., GARCIA M.G.M., DEHIRA L.K. 2015. Urban Geotourism and the Old Centre of São Paulo City, Brazil. Geoheritage $7: 147-164$.

DIAS NETO C.M., FONSECA P.E., MUNHÁ J., EGYDIO SILVA M., RIBEIRO A. 2006. A estrutura em flor (flower structure) do Complexo Costeiro (Faixa Ribeira) em São Sebastião (São Paulo, Brasil). Cadernos Laboratório Xeolóxico de Laxe, La Curuña, v. 31, p. 105-125, 2006.

FITZNER B., HEINRICHS K. 2004. Photo Atlas of weathering forms on stone monuments. Disponível em: <http://www.stone.rwth-aachen.de>. Acesso em: 25 jun. 2007.

FREITAS R.O. 1976. Definição petrológica, estrutural e geotectônica das cintas orogênicas antigas do litoral norte do estado de São Paulo. Boletim IGc, 1:1-175.

FUNDART - FUNDAÇÃO DE ARTE E CULTURA 2015a. Ruínas da Lagoinha. Disponível em: <http://fundart.com.br/dt_portfolio/ruinas-da-lagoinha/> acessado em junho de 2015.

FUNDART - FUNDAÇÃO DE ARTE E CULTURA 2015b. Sobradão do Porto. Disponível em: < http://fundart.com.br/dt_portfolio/sobradao-do-porto/> acessado em junho de 2015.

GARDA G.M. 1995. Os diques básicos e ultrabásicos da região costeira entre as cidades de São Sebastião e Ubatuba, Estado de São Paulo. Tese (Doutorado), Instituto de Geociências, Universidade de São Paulo, São Paulo, p. 349.

GRAY M. 2004. Geodiversity: valuing and conserving abiotic nature. John Wiley \& Sons. 508p.

HASUI Y. 2010. A grande colisão pré-cambriana do sudeste brasileiro e a estruturação regional Geociências, UNESP, São Paulo, v.29, n.2, p.141-169. 
HEILBRON M., PREDOSA-SOARES A.C., CAMPOS NETO M.C., SILVA L.C., TROUW R.A.J., JANASI V.A. 2004. Província Mantiqueira. In: Mantesso-Neto et al. (Org.) - Geologia do Continente Sul-Americano - Evolução da Obra de Fernando Flávio Marques de Almeida, p. 203-234.

IBGE - INSTITUTO BRASILEIRO DE GEOGRAFIA E ESTATÍTICA 2010. http://www.censo2010.ibge.gov.br, Acessado em 25 de agosto de 2011.

ICOMOS - INTERNATIONAL COUNCIL ON MONUMENTS AND SITES 2008. Glossário ilustrado das formas de deterioração da pedra. champigny/Marne, França: ICOMOS. 83p. Disponível em: <http://www.icomos.pt/images/pdfs/Glossario_Pedra_Icomos.pdf $>$. Acessado em maio de 2017.

LICCARDO A., PIEKARZ G., SALAMUNI E. 2008. Geoturismo em Curitiba. Mineropar, Curitiba. 122p.

LICCARDO A., MANTESSO-NETO V., PIEKARZ G. 2012. Geoturismo Urbano Educação e Cultura. Anuário Instituto de Geociências, 35(1):133-141.

MANSUR K.L., CARVALHO I.S., DELPHIM C.F.M., BARROSO E.V. 2008. O Gnaisse Facoidal: a mais Carioca das Rochas. Anuário do Instituto de Geociências, 31(2):9-22.

NASCIMENTO M.A.L., SILVA M.L.N., BEZERRA G.B. 2016. Centro Histórico da Cidade de Natal: roteiro geoturístico por monumentos construídos com diferentes rochas. Revista Geografia: Conhecimento Prático, 64: 52-59.

PERROTA M.M., SALVADOR E.D., LOPES R.C., D'AGOSTINHO L.Z. 2005. Mapa geológico do Estado de São Paulo, escala 1:750.000. Programa levantamentos geológicos básicos do Brasil, CPRM, São Paulo, 2005.

PHILIPP R.P., VARGAS J.A., DI BENEDETTI V. 2009. A memória geológica do centro antigo de Porto Alegre: o registro da evolução urbana nos prédios históricos e no urbanismo da cidade. Pesquisas em Geociências, 36(1):59-77.

PINTO A. 2015. Geodiversidade e Patrimônio Geológico de Salvador: uma diretriz para a geoconservação e a educação em geociências. Tese (Doutorado), Instituto de Geociências, Universidade Federal da Bahia, Salvador, p. 332.

PINTO C.P., DRUMOND J.B.V., FÉBOLI W.L. 2001. Nota explicativa do mapa geológico integrado. Etapa 1. Folhas SE 24-V, SE25-Z, SE24-Y (partes). Belo Horizonte, Projeto Leste, CPRM-COMIG, pp 12-18.

PROCHOROFF R. 2014. Patrimônio geológico de Ilhabela-SP.: estratégias de geoconservação. Dissertação (Mestrado). São Paulo, 2014. 176 p.

REVERTE F.C. 2014. Avaliação da Geodiversidade em São Sebastião - SP, com Patrimônio Geológico. Dissertação (Mestrado), Institudo de Geociências/ USP, São Paulo. 208p. 
REVERTE F.C., GARCIA M.G.M. 2016. O patrimônio geológico de São Sebastião SP: Inventário e uso potencial de geossítios com valor científico. Geociências (São Paulo. Online), 35:495-511.

REYS A.C., DEL LAMA E.A., DEHIRA L.K. 2008. Monumentos da cidade de São Paulo: formas de alteração e conservação. Revista CPC (Centro de Preservação Cultural da USP) 5:93-122.

ROBINSON E. 1982. A geological walk around the City of London-royal exchange to Aldgate. Proceedings of the Geologists’ Association 93:225-246.

ROBINSON E. 1984. London: illustrated geological walks. Scottish Academic Press, v.1.

ROBINSON E. 1985. London: illustrated geological walks. Scottish Academic Press, v.2.

ROBINSON E. 1987. A geology of the Albert Memorial and vicinity. Proc Geol Assoc 98:19-37.

ROBINSON E. 1988. A geological walk in Clerkwell, London. Proc Geol Assoc 99:101-124.

ROBINSON E. 1993. A geological walk in Southwark. Proc Geol Assoc 104:285-299.

ROBINSON E. 1997. The stones of the Mile End Road: a geology of Middlemiss country. Proc Geol Assoc 108:171-176.

ROBINSON E., BISHOP C. 1980. Geological walks around St. Paul's. Proc Geol Assoc 91:241-260.

RODRIGUES N.M. 2012. Ensaios não destrutivos em monumentos pétreos paulistanos. Monografia de Trabalho de Formatura. Instituto de Geociências, Universidade de São Paulo (IGc-USP). 75p.

SANTOS P.L.A. 2014. Patrimônio Geológico em Áreas de Proteção Ambiental: Ubatuba - SP. Instituto de Geociências - USP. Dissertação de Mestrado. São Paulo, 207 p.

SCIFONI S. 2006. A construção do patrimônio natural. Tese de doutorado. Faculdade de Filosofia, Letras e Ciências Humanas da Universidade de São Paulo, São Paulo, $294 p$.

SEADE - FUNDAÇÃO SISTEMA EDUCACIONAL ANÁLISE DE DADOS 2011. Informações dos Municípios Paulistas - IMIP. Disponível em: <http://produtos.seade.gov.br/produtos/imp/> acessado em Maio de 2015.

SECTUR - SECRETARIA DE CULTURA E TURISMO 2015. Explorando a História: São Sebastião no tempo. Secretaria de Cultura e turismo, disponível em: $<$ http://turismo.saosebastiao.sp.gov.br/pt/explorando-a-historia/sao-sebastiao-notempo> acessado em junho de 2015. 
STERN A.G., RICCOMINI C., FAMBRINI G.L., CHAMANI M.A.C. 2006. Roteiro geológico pelos edifícios e monumentos históricos do centro da cidade de São Paulo. Revista Brasileira de Geociências 36(4):704-711.

WEBER P., BAUDIN F., PEREIRA D., CORNÉE A., EGOROFF G., PAGE K. 2016. The Importance of Geosites and Heritage Stones in Cities—a Review. Geoheritage (Publicação Online). 